Louisiana State University

LSU Digital Commons

LSU Historical Dissertations and Theses

Graduate School

1970

\title{
The Army in Texas During Reconstruction, 1865-1870.
}

William Lee Richter

Louisiana State University and Agricultural \& Mechanical College

Follow this and additional works at: https://digitalcommons.Isu.edu/gradschool_disstheses

\section{Recommended Citation}

Richter, William Lee, "The Army in Texas During Reconstruction, 1865-1870." (1970). LSU Historical Dissertations and Theses. 1881.

https://digitalcommons.Isu.edu/gradschool_disstheses/1881

This Dissertation is brought to you for free and open access by the Graduate School at LSU Digital Commons. It has been accepted for inclusion in LSU Historical Dissertations and Theses by an authorized administrator of LSU Digital Commons. For more information, please contact gradetd@lsu.edu. 
RICHTER, William Le e, 1942-

THE ARMY IN TEXAS DURING RECONSTRUCTION, 1865-1870.

The Louisiana State University and Agricultural and Mechanical Colzege, Ph.D., 1970

History, general

University Microlīm s, Inc., Ann Arbor, Michigan

(C) 1971

WILALIAM LEE RICHTER

ALL RIGHTS RESERVED

THIS DISSERTATION HAS BEEN MICROFILMED EXACTLY AS RECEIVED Reproduced with permission of the copyright owner. Further reproduction prohibited without permission. 
THE ARMY IN TEXAS DURING RECONSTRUCTION, 1865-1870

\author{
A Dissertation \\ Submitted to the Graduate Faculty of the \\ Louisiana State University and \\ Agricultural and Mechanical College \\ in partial fulfillment of the \\ requirements for the degree of \\ Doctor of Philosophy
}

by

William L. Richter

B.A., Arizona State University, 1964

M.A., Arizona state University, 1965

August, 1970 


\section{ACKNOWLEDGMENTS}

In any work of this size, the author finds himself indebted to a great many people. Professor T. Harry Williams admirably guided my research and writing, giving much needed advice and criticism. Professor Burl Noggle rates a special word of thanks for his interest in my career and studies, as do Professors Charles B. Dew of the University of Missouri and James E. Sefton of Sa: Fernando Valley State College. The members of my graduate committee, Professors John L. Loos, Robert Holtman, J. Preston Moore, James Bolner, and James G. Zeidman, all contributed much time, knowledge, and understanding to my education. I would like to thank the directors and staffs of the following institutions for assisting me with my research: the National Archives; the Manuscripts Division of the Library of Congress; the Barker Historical Center, the Archives, the Newspaper Collection, and the Library of the University of Texas; the Archives of the Texas State Library and Austin Public Library; the Department of Archives and Manuscripts and the Interlibrary Loan Desk of the Louisiana State University Library. My research was made possible by a grant from the Warrick Memorial Fund of Louisiana State University.

I am grateful to three professors at Arizona State University, Paul Hubbard, Otis E Young, and Ron Smith, for opening up the fascinating world of history to me. Most of all, I am indebted to my wife Lynne. Her love and assistance made everything possible. 
TABLE OF CONTENTS

Page

ACKNOWLEDGMENTS .................. . . iii

LIST OF TABLES . . . . . . . . . . . . . . . . . . . $\mathrm{V}$

LIST OF MAPS . . . . . . . . . . . . . . . . vi v vi

ABSTRACT ....................... . . . vii

EXPLANATION OF FOOTNOTES ................... . . ix

Chapter
I. NEVER WHIPPED IN SPIRIT . . . . . . . . . . . 1

II. A BREACH OF FAITH . . . . . . . . . . . . . . . 29

III. THE LAST ACT OF THE REBELLION . . . . . . . . . . 57

IV. SUBMISSION BUT NOT ACCEPTANCE . . . . . . . . . . 79

V. NOT STRONG ENOUGH TO CARRY AN ELECTION . . . . . . . 99

VI. "WE MUST RUBb OUT AND BEGIN ANEW" . . . . . . . . . 122

VII. INDUSTRIOUSLY MANIPULATED . . . . . . . . . . . 144

VIII. "OUTSIDE THE DUTY OF MY PROFESSiON" . . . . . . . . 167

IX. UNDENIABLE TRUTHS . . . . . . . . . . . . . 187

X. LACKING WATER AND GOOD SOCIETY . . . . . . . . . . 212

XI. EQUAL JUSTICE FOR ALI . . . . . . . . . . . . 237

XII. SPREAD-EAGLE ECCENTRICITIES . . . . . . . . . . 253

XIII. A MATTER OF PRIORTTIES .............. . 274

XIV. BEYOND THE BOUNDS OF TRUTH AND RIGHT . . . . . . . 305 BIBLIOGRAPHY . . . . . . . . . . . . . . . . 321

VITA . . . . . . . . . . . . . . . . 345 
Table Page

1. Troops Musterec out in Texas, 1865-1867 . . . . . . . 50

2. Commanding officers and Governors of Texas . . . . . - 109

3. Reoccupation of Texas Forts . . . . . . . . . . . . 293

4. Numbers of Teoops Stationed in Texas . . . . . . . . . 294 
1. Proportions of slaves ................ 2

2. Vote on Secession................ 2

3. Proportions of Germans .. . . . . . . . . . . . . 2

4. Civil War Invasions . . . . . . . . . . . . 17

5. Rio Grande Valley . . . . . . . . . . . . . 58

6 Pre-Civil War Frontier ............. 275

7. Civil War Frontier . . . . . . . . . . 278

8. Reconstruction Frontier . . . . . . . . . . . 291 
ABSTRACT

Recent historians assert that the role of the Army during Reconstruction has been exaggerated and that its influence was minimal because there were few troops located in the South. Other scholars claim that influence is not a function of numbers and that the Army's power in Reconstruction was substantial. In Texas, the truth of the latter contention is ably demonstrated by the Army's influence in state politics. Contrary to the usual picture, General Philip H. Sheridan actually proved to be an impediment to Republican goals because he refused to remove and appoint local officials on the basis of party alone. Generals Charles Griffin and Joseph J. Reynolds, however, built the Republican party because they did make partis an appointments to office. President Andrew Johnson tried to stem Reynolds' power by appointing General Winfield s. Hancock, a Democrat, as his superior. But Hancock resigned when General U. S. Grant curtailed his authority in behalf of the Republicans. Johnson then replaced Reynolds with General E. R. S. Canby whose measured rule helped produce a new state constitution and end lawlessness. Upon Grant's election as President in 1868, Reynolds returned to Texas where he was instrumental in assuring the dominance of the Radicals when the Republican party split into rival factions in 1868-1869.

In general, Reynolds' political meddling notwithstanding, the Army conducted itself well in Texas. It handled the race question 
with relative conservatism, defended the frontier, suppressed outlaws, held reasonably fair trials, curtailed the spread of contagious diseases, and administered even minor governmental affairs on the county and municipal levels. Yet Texans hated the Army and Reconstruction and often openly expressed their dislike. They murdered individual soldiers, attacked larger troop units, plundered wagons, and initiated harassing legal actions in state courts.

When the positive and negative aspects of military rule are combined, Texans opposed military rule for one basic reason--they believed it was a denial of the basic right of self-government. Texas had a long history of fighting real or supposed tyrannies: it revolted against Mexico to gain self-rule, its antebellum politics vere largely controlled by states rights Democrats, and its governors and legislatures vigorously opposed Confederate military rule during the Civil War. Texans believed that Military Reconstruction was merely one more form of tyranny to be overcome before they could enjoy their full rights under the democratic process.

viii 
EXPLANATION OF FOOTNOTES

The National Archives, Washington, D.C., has a large collection of primary documents concerning the Army's role in Texas Reconstruction. Record Group 94 contains the monthly manuscript returns showing the number of troops for each post located in Texas (these are cited as "Manuscript Returns"). The same record group holds bound volumes of printed orders issued by the various headquarters in Texas (Military Division of the Southwest, Department of the Gulf, District of Texas, Fifth Military District), and the Civil Affairs offices of these commands. These orders are cited as "GO" (General Ordexs) or "SO" (Special Orders) followed by the order's number, the date, the words "Printed Orders," and tize headquarters issuing the order (e.g., GO 6, April 8, 1867, Printed Orders, Fifth Military District). Orders issued by the Civil Affairs offices will be cited as in the following: Go 6 , April 8, 1867, Civil Affairs, District of Texas. The Civil Affairs orders and regular orders often duplicate each other. They can be found in manuscript form in Record Group 303. Also in the latter record group are the letter books containing copies of the letters ani telegrams sent or received by the various headquarters. They are cited giving the names of the sender, the party to whom the document was sent, the date, the headquarters involved, and the word "records." (For example, John Smith to Sheridan, November 8, 1866, Letters Received, Department of the Gulf records). The Texas Freedmen's 
Bureau documents (Record Group 105) will be cited in a manner similar to that used for the orders (GO 6, April 8, 1867, Texas Freedmen's Bureau) and letters (Kiddoo to Kirkman, April 10, 1866, Letters Sent, Texas Freedmen's Bureau records).

FOOTNOTE ABBREVIATIONS

AAG

AAAG

AGO

Circ.

$\mathrm{CO}$

$\mathrm{C} / \mathrm{S}$

GO

HQ

SO

USA
Assistant Adjutant General

Acting Assistant Adjutant General

Adjutant General's Office

Circular

Commanding officer

Chief of Staff

General Orders

Headquarters

Special Orders

United States Army 


\section{NEVER WHIPPED IN SPIRIT}

Texas Reconstruction was naturally infiuenced by events that preceded the postwar era. These incidents are important because they explain why certain actions were taken by the Federal authorities and the Texans in response to the issues of Reconstruction in the state. Of special significance are the secession crisis, the Civi] War, the role assumed by Lieutenant General Edmund Kirby Smith in commanding the Trans-Mississippi Department, Texas Unionism, and the manner in which the state surrendered to the North in 1865.

Texas history, until shortly before the Civil war, was determined by issues left over from the days of the Republic. The state was burdener with a heavy debt, boundary disputes, and perennial Indian attacks on its western frontier. The debt and boundary problems were settled by the Compromise of 1850, but the frontier troubles would last another quarter of a century before the marauding Indians were subdued. As the decade before the Civil war ended, the rising debate over slavery and states rights came more and more to the fore in state politics. The Kansas-Nebiraska Act first drew Texans' attention away from local issues, and was instrumental in the election of Hardin $R$. Runnels, a states rights Democrat, in 1857. Alarmed by Runnels' victory, the more conservative leaders of Texas joined together behind Sam Houston. Two years later Houston's Independent party administered a stunning defeat to the Runnels ticket. Houston was elected governor 


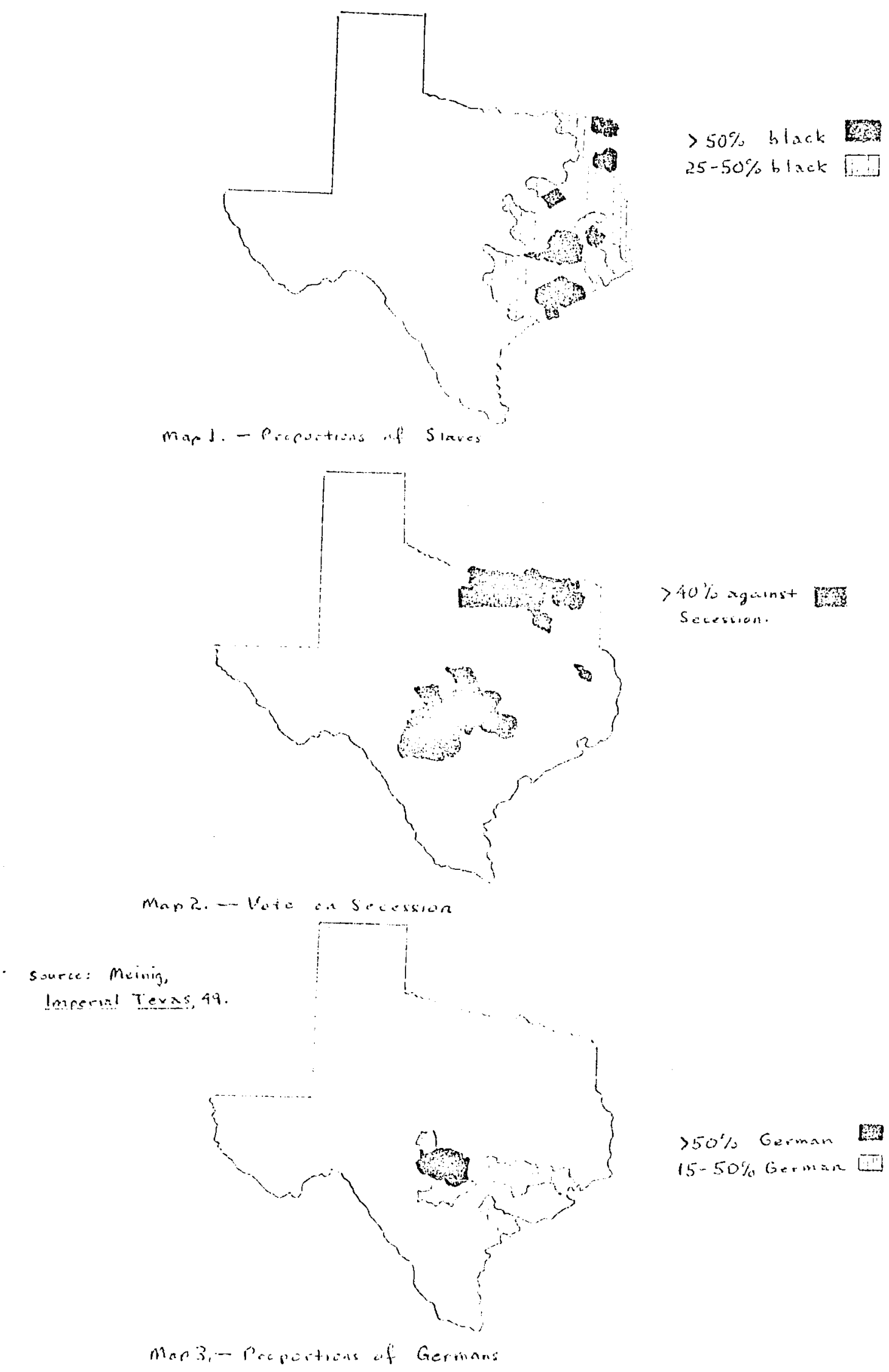


and Andrew J. Hamilton, a Houston man, defeatid his opponent for the congressional seat of the western district of the statc. The Democrats managed to hold onto the other seat which was won by John H. Reagan, later postmaster general of the Confederacy. 1

Houston's high hopes for a moderate course of action were dashed when John Brown raided the Federal arsenal at Harpers Ferry, Virginia. This incident was followed by the uncovering of an abolitionist-inspixed slave revolt plot in northern Texas. Mysterious fixes were traced to "abolitionist agents," suspected men were whipped for slave tampering, and two men were hanged in Gonzales for the same crime. In response to these happenings, the state legislature elected Louis T. Wigfall to the United States Senate. Wigfall was especially obnoxious to Houston because he was one of the most rabid states rights men in Texas. 2

Abraham Lincoln's election in 1860 caused many Texans to demand that a state convention be called to consider the state's relation to the Union. But the Secessionists were handicapped because the state legislature was not in session at the time. The legislature, as the branch of government closest to the people, was supposed to call the convention. Houston, an old Jacksonian, was determined to preserve the Union and refused to cause the legislature to convene. The Secessionists were equally determined, however, to have the convention. Their

\footnotetext{
${ }^{1}$ Charles W. Ramsdell, Reconstruction in Texas (New York, 1910), $11-13$

${ }^{2}$ Ibid., 13; William W. White, "The Texas slave Insurrection of 1860," Southwestern Historical Quarterly, LII (1948-49), 259-r-; Marcus Ilewelyn Arnold, "The Later Phases of the Secessionist Movement in Texas" (Unpublished M.A. thesis, University of Texas, Austin, 1920), $7-8,32,72,73,75$.
} 
leaders met at Austin in December 1860, and proposed that the state choose delegates to a convention anyway. The chief justice, one or more county commissioners, or a committee of interested citizens was to hold the election on January 8, 1861. Each representative district was to select twice as many delegates to the convention as it had representatives to the state legislature. ${ }^{3}$

Houston decided to meet the challenge and called the state legislature into session one week before the impending election. Houston accused the Secessionists of illegal procedure and of being unxepresentative of the people. His request to outlaw the election, however, failed to move the legislature, which voted to recognize the authority of the convention with the stipulation that its actions be submitted to a referendum of the people. On January 8 those districts that voted elected a predominantly secessionist majority to the convention. The delegates met in Austin and nullified the ordinance of annexation of 1845, claiming that the United States had failed to protect the frontier settlers, that the northern states had violated the guarantees of the constitution, and that the Federal government was going to threaten the interests and property of Texas and the South. The vote was 166 to 8 in favor of the ordinance of secession. 4 The convention then established a "committee on public safety" to defend the state. The first order of business for the committee

3Ramsdel1, Reconstruction in Texas, 14-15.

4 Ibid., 15-17; Robert Patterson Felgar, "Texas in the War for Southern Independence" (Unpublished Ph.D. dissertation, University of Texas, Austin, 1935), 24-53; Ralph A. Wooster, "An Analysis of the Membership of the Texas Secession Convention," Southwestern Historical Quarterly, LXII (1958-59), 322-35. 
was to obtain the surrender of the United states soldiers in Texas and secure all available war materiel for state use. Hundreds of volunteers commanded by Colonel Ben McCulloch began to advance on the Army headquarters at San Antonio. In the face of an overwhelming force, Brigadier General. David E. Twiggs, the United States officer in charge, decided not to resist the inevitable and surrendered. McCulloch allowed the Regulars to keep their arms, provisions, tents, and artillery, but he ordered them to march to the coast and embark for northern ports. The final thirteen companies did not arrive on the coast until April 11, 1861. The recently arrived Major General Earl Van Dorn, representing the Confederate states of America, ordered these men made prisoners of war, disarmed and paroled, before they were shipped north. 5

In the meantime, the voters of: Texas had approved the ordinance of secession 44,317 to 13,020 . Considering this to be sufficient endorsement for its legality, the convention met again and approved the provisional constitution of the Confederacy. Texas delegates were already in Montgomery, Alabama, and the Confederate provisional congress admitted them to the new nation. Back in Texas, the convention continued its work in spite of the vociferous opposition of

5Felgar, "Texas in the War for Southern Independence," 54-68; Jack Winston Gunn, "The Life of Ben McCulloch" (Unpublished M.A. thesis, University of Texas, Austin, 1947), 94-95; W. J. Hughes, Rebellious Ranger: Rip Ford and the old Southwest (Norman, 1964), 194-98; John Henry Brown, History of Texas From 1685 to 1892 (2 vols., St. Louis, 1893), II, 442; Caroline Silsby Ruckman, "The Frontier of Texas During the Civil War" (Unpublished M.A. thesis, University of Texas, Austin, 1925), 9-23; Ramsdel1, Reconstruction in Texas, 18; Arnold, "Later phases of the Secessionist Movement," $\overline{98}$; Jesse Beryl Boozer, "The History, of Indianola, Texas" (Unpublished M.A. thesis, University of Texas, Austin, 1942), 76-78. 
Houston, who refused to recognize any act beyond the February 1 secession ordinance. The convention altered the state constitution to conform to that of the Confederacy, and required all elected officials to take an oath to the Confederate States of America or vacate their office. Only Houston and E. W. Cave, his secretary of state, refused. On March 16, the convention declared the governor's office vacant and instructed Lieutenant Governor Edward Clark to take over the state executive role. As Houston departed, he fired off a bitter denunciation of the "usurpations" of the convention before he retired to private life. 6

The Civil War was basically an uneventful time in Texas. The Yankees never had the strength to mount a real invasion, even though they temporarily occupied Galveston, Indianola, and parts of the Rio Grande Valley during the war. The few battles that were fought were speciacular Confederate successes with the most shining one being the expulsion of the Federals from Galveston in January 1863. An attempt to mount an offensive up the Sabine River failed when Major Dick Dowling and a group of determined artillerymen drove back a poorly led Union invasion fleet. Across the Sabine in Louisiana, another invasion force was stopped by Major General Dick Taylor's army at Mansfield below Shreveport. In the Rio Grande valley, the only real possession the Yankees could consistently claim was Brazos Isiand. An attempt to include Brownsville in the bluecoats' sphere of control was masterfully turned back by Colonel John "Rip" Ford at Palmetto Ranch on May 12, 
1865, in the last battle of the Civil war. The Texans had never been militarily defeated and this fact produced a sort of cockiness that manifested itself after the war. ${ }^{7}$

Economically, Texas ended the war in the best condition of any southern state. Two Eactors figured in this economic status. First, the lack of invading armies meant that few crops were destroyed in the field. The ravages of $w$ ar had caused many slaves to be brought into Texas from Arkansas and Louisiana for safekeeping. The enlarged labor force had helped increase the production of corn and cotton. The only real impediments to farming were getting the finished crop to market in Brownsville, and avoiaing Confederate cotton agents. At first, cotton had been bought by the government, but the vast size of Texas, combined with the lack of a clear hierarchy of authority over purchasing agents led to confusion. The aifferent agents let out subcontracts and flooded the state with purchasing men, which drove up prices because the contractors competed among themselves for the crop. To solve the problem, the Confederacy adopted an impressment law, by which ten per

7 Ramsdell, Reconstruction in Texas, 21-26; Hughes, Rebellious Ranger, 237-41; Brown, History of Texas, II, 431-35; Felgar, "Texas in the War for Southern Independence," 169-99; Allen W. Jones, "Military Events in Texas During the Civil War, 1861-1865," Southwestern Historical Quarterly, IXIV (1960-61), 64-70; Alwyn Barr, "Texas Coastal Defense, 1861-1865," ibid. , IXV (1961-62), 1-31; Lester N. Fitzhugh, "Saluria, Fort Esperanza, and Military Operations on the Texas Coast, 1861-1865," ibid., IVI (1957-58), 66-100; Charles C. Cumberland, "The Confederate Loss and Recapture of Galveston, 1862-.2863," ibid., II (1947-48), 109-30; Jo Young, "The Battle of Sabine Pass," ibid., III (1948-49), 398-409; Stephen B. Oates, "Texas under the Secessionists," ibid., LXVII (1963-64), 167-212; Stephen B. Oates, "Recruiting Confederate Cavalry in Texas," ibid., LXIV (1960-6I), 463-64; Stephen B. Oates, "John S. 'Rip' Fora: Prudent Cavalryman, C.S.A.," ibid., 289314; Boozer, "The History of Indianola," 78-80; Thomas Franklin Anderson, "A History of Indianola" (Unpublished M.A. thesis, University of Houston, 1951), 63-66. 
cent of a farmer's goods were confiscated in lieu of taxes. ${ }^{8}$

In response to complaints by planters, the state legislature passed an act on May 28, 1864, which prohibited interference by any person with private property. The punishment was a one hundred dollar fine or a year in jail. If the interference was done by official orders, the fine was two hundred dollars or four years in jail or both. All cases were to be tried in state courts. More often, however, the cotton agent was merely run out of town. If he were too persistent in his job, he was bushwacked on a lonely road. Most citizens felt the agents were thieves who robbed the people of ten per cent of theix goods and then sold the products for the agents' own enrichment. 9 Not all areas of Texas were free from suffering; because of transportation difficulties, there were food shortages. In 1863 storekeepers in Travis County were reported to be selling only to purchasers with gold

${ }^{8}$ George W. Sergeant, "The Early History of Tarrant County" (Unpublished M.A. thesis, University of Texas, Austin, 1953), 172; Frank Edd White, "A History of the Territory that Now Constitutes Waller County, Texas, From 1821 to 1884" (Unpublished M.A. thesis, University of Texas, Austin, 1936), 104, 107; James Verdo Reese, "A History of Hill County, Texas, to 1873" (Unpublished M.A. thesis, University of Texas, Austin, 1961), 132; Agnes Louise Lambie, "Confederate Control of Cotton in the Trans-Mississippi Department" (Unpublished M.A. thesis, University of Texas, Austin, 1915), 28, 41, 85-86; Jonnie Mildred Megee, "Confederate Impressment Acts in the TransMississippi Department" (Unpublished M.A. thesis, University of Texas, Austin, 1915), 96, 97, 149, 151; H. H. Bancroft, History of the North Mexican States and Texas (2 vols., San Francisco, 1889), II, $\frac{173-74 ;}{4}$ Ernest Wallace, Texas in Turmoil (Austin, 1965), 125-27; James L. Nichols, The Confederate Quartermaster in the Irans-Mississippi (Austin, 1964), 43-83.

$9_{\text {Extralegal proceedings of this sort were used against Federal }}$ employees after the war, also, with some effect. Ramsdell, Reconstruction in Texas, 23--24; Megee, "Confederate Impressment," 152, 155, 157, 170-71; Annie Cowling, "The Civil War Trade of the Lower Rio Grande Valley" (Unpublished M.A. thesis, University of Texas, Austin, $1926), 146$. 
or silver money. Other suppliers were accused of hoaraing products, hoping to monopolize trade when the supply became critically low. But Yankee soldiers were astounded at the amounts of hard currency in circulation throughout the state at the war's end in 1865.10

The second reason for Texas' prosperity was the proximity of Mexico. Texas was the only southern state with an international border. In addition, the Rio Grande was not navigable by Union warships because they drew too deep a draft. Under international law, no blockade was legal unless the port was closed by warships. Thus, Brownsville was open nearly the whole war since Union ships could not navigate the Rio Grarde up to the port. The lighter blockade runners, ostensibly headed for Matamoros, passed the Yankee fleet with impunity. As many as one hundred ships a month visited the Mexican port directly opposite Brownsville, and Matamoros grew into a boom town overnight. Brownsville was so important as a receiving area that Colonel John Ford made a concerted, successful effort to recapture the town in 1863 after it fell to the Yankees. 11

In contrast to this even economic development, Texas' relations with Confederate authorities were often far from smooth. Although Francis R. Lubbock, the first wartime governor, had some problems with cotton agents and local county officials who refused to obey Con-

10 Wallace, Texas in Turmoil, 130; Charles T. Clark, Opdycke Tigers, 125th Ohio Volunteer Infantry . . (Columbus, 1895), 403; Mary starr Barkley, History of Travis County and Austin, 1839-1899 (Waco, 1964), 91.

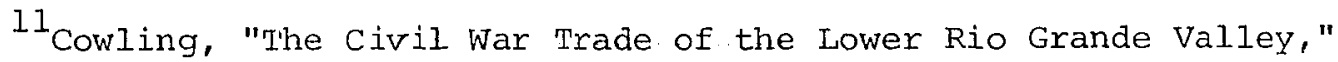
17, 18, 23-24, 27, 30; Wallace, Texas in Turmoil, 128-30; Robert W. Delaney, "Matamoros, Port for Texas During the Civil War," Southwestern Historical Quarterly, LVIII (1954-55), 473-87. 
federate authorities, it remained for his successor, Pendleton Murrah, to assert the states rights doctrine to its fullest implications. By the time Murrah took office in late 1863, the fortunes of the Confederacy had begun to wane. The governor felt his basic purpose in office was to protect Texas and preserve its citizens' property. When Texan desires conflicted with Richmond's wish to win the war at all cost, Richmond suffered. Murxah refused to obey the conscrirt laws fully, and his quibbling kept thousands of able-bodied men out of the service. He also received the power from the state legislature to appoint brigadier generals, and he tried to force Richmond to recognize these state commissions. The only Confederate act he did agree with was the suspension of the writ of habeas corpus. His approval, however, merely consisted of not objecting to its enforcement; he never did wholeheartedly support the law. 12

The Trans-Mississippi Department, of which Texas was a part, occupied a unique position after the culmination of the Vicksburg-Port Hudson campaigns in 1863. These actions separated the Rebel state governments in Missouri, Arkansas, Louisiana, and Texas from the rest of the Confederacy. It was obvious to the southern officials west of the river that their isolated condition would make it difficult to communicate rapidly with the Richmond government. Accordingly, representatives from the four western confederate states $^{13}$ met in

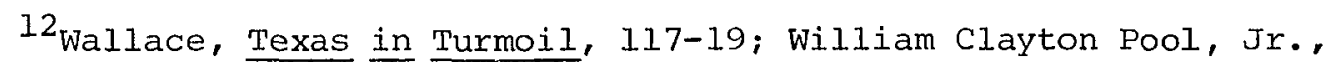
"The History of Bosque Courity" (Unpublished M.A. thesis, Jniversity of Texas, Austin, 1946), 73-74; Ida Mae Myers, "The Relation of Governor Pendleton Murrah of Texas with the Confederate Military Authorities" (Unpublished M.A. thesis, University of Texas, Austin, 1929), 112-.14.

13 In addition to Kirby Smith, the members attending the conference were Robert W. Johnson, C. B. Mitchell, and W. K. Patterson 
Marshall, Texas, on August 15, 1863, to discuss the situation and formulate a joint plan of action. The conclusion of the representatives was that the Trans-Mississippi Department was so disconnected from the rest of the South as to make a separate nation within the Confederacy and, as such, it should have the right to act independently of the Richmond government. 14

Although President Jefferson Davis did not openly agree to this departure from the Confederate constitution, he quietly sanctioned the authority of the commander of the Trans-Mississippi Department, Lieutenant General Edmund Kirby Smith, to assume additional powers of government. Kirby Smith was permitted to handle the military functions of the secretary of war, establish bureaus similar to those in Richmond, and take care of all military functions except the right to permanently promote officers; and he was also given command of all areas in the department that had been independent of his jurisdiction before. In addition, Kirby Smith was told to form a civil government, but no details were sent on its composition. In December 1863, the Confederate Congress extended Kirby Smith's powers, and made them

from Arkansas; Governor Thomas O. Moore, Colonel T. C. Manning, W. Merrick, and Albert Voorhies from Louisiana; Governor Thomas C. Reynolds from Missouri; Governor Frank Lubbock, W. S. Oldham, Colonel Pendleton Murrah, and Major Guy M. Bryan from Texas. See Florence Elizabeth Holladay, "The Extraordinary Powers and Functions of the General Commanding the Trans-Mississippi Department of the Southern Confederacy" (Unpublished M.A. thesis, University of Texas, Austin, 1914), 14-15.

14 Ibid., 15-26; Lt. Gen. E. Kirby Smith to President Jefferson Davis, September 11, 1863, and Secretary of War J. A. Seddon to Kirby Smith, October 10, 1863, in The War of the Rebellion: The Official Records of the Union and Confederate Armies (128 vols., Washington, $\frac{18}{180-1901)}$, Series 1, XXII, Pt. 2, 1003-10, 1038-42. Hereinafter cited as $\underline{\text { O. }}$. . , with all references to Series 1 , unless otherwise noted. 
formal and official. The Trans-Mississippi Department was to duplicate all of the functions of the executive branch of government, and the region was recognized as completely separate from the Cis-Mississippi Confederacy. Although Kirby Smith was not allowed the explicit authority to reproduce the entire confederate government on a smallex scale, the Confederate Congress acquiesced in his personal assumption of even wider powers of civil government as the situation demanded.15 Kirby Smith received the support and cooperation of the people within the Trans-Mississippi lines until the spring of 1864 . Then the general tried to enforce the conscription law, impress cotton, and control transportation and trade to enhance the war effort. Immediately, the governors of Louisiana and Texas reversed the position they had assumed at the Marshall conference and opposed the general's actions. The opposition asserted that the military control of government was blatantly unconstitutional, especially after the defeat of the Yankee army at Mansfield had removed the threat of invasion. The general's desire to continue in his control of the government was seen as an attempt on his part to disregard constitutional rule altogether. Although Kirby Smith was able to persevere in his aim, it is significant that ruch of his most vehement opposition came from Texas, the largest and only intact state in his command. 16 Modern historians declare that states rights or an overdose of democracy was instrumental

\footnotetext{
15Holladay, "The Extraordinary Powers and Functions of the General Commanding," 32, 47, 58-59, 64, 75, 82, 97.

16 Ibid. , 144, 149-50, 151 .
} 
in defeating the Confederacy. ${ }^{17}$ Texans opposed Kirby Smith's control of state government and they will oppose Reconstruction, the Union control of state government, just as ardently. Texans had no inclination to allow any outside power to run local politics, no matter how noble or ignoble a cause they represented. States rights may have killed not only the confederacy, in the last analysis, it also assumed a large role in defeating Reconstruction. 18

Another factor that helped weaken not only Texas, but the entire South, was the presence of a large number of Union sympathizers ir each state. 19 The wartime Unionists were important later in Reconstruction,

17Frank L. Owsley, State Rights in the Confederacy (Chicago, 1925); David Donald, "Died of Democracy," in David Donald (ed.), Why the North Won the Civil War (New York, 1962), 79-90.

${ }^{18}$ See for example, Alma Dexta King, "The Political Career of Williamson Simpson Oldham" (Unpublished M.A. thesis, University of Texas, Austin, 1929), 185. Oldham felt that the Confederacy was defeated by too much centralism, not from the lack of it.

${ }^{19}$ In general, for reasons why the South lost the war, see Donald (ed.), Why the North Won the Civil War; and Robert D. Little, "Southern Historians and the Downfall of the Confederacy," Alabama Review, III (1950), 243-62, and ibid., IV (1951), 38-54. For Unionist feeling in the South, see Ella Lonn, Desertion During the Civil War (New York, 1928); Hugh C. Bailey, "Disaffection in the Alabama Hill Country, 1861," Civil War History, IV (1958), 183-94; Harold M. Hyman, "Deceit in Dixie," ibid., III (1957), 65-82; John K. Bettersworth (ed.), "Mississippi Unionism: The Case of the Reverend James A. Lyon," Journal of Mississippi History, I (1939), 37-52; Barnes F. Lathrop, "Disaffection in Confederate Louisiana: The Case of William Hyman," Journal of Southern History, XXIV (1958), 308-18; Henry T. Shanks, "Disloyalty to the Confederacy in Southwestern Virginia, 1861-1865," North Carolina Historical Review, XXI (1.944), 118-35; Horace W. Raper, "william H. Holden and the Peace Movement in North Carolina," ibid., XXXI (1954), 493-516; J. Ruben Sheeler, "The Development of Unionism in East Tennessee," Journal of Negro History, XXIX (1944), 166-203; and Ted R. Worley, "The Arkansas Peace Society of 1861: A Study in Mountain Unionism," Journal of Southern History, XXIV (1958), 445-56. 
for many of them supported Reconstruction and provided southern leadership in the Republican party. The composition of the state's population again placed Texas in a unique position in the Confederacy. Three-fourths of her people were recent immigrants from other states or foreign nations. Texas had the largest foreign element of any Confederate state. Most of these foreigners were Germans who had begun to settle in Texas as early as 1831. In the 1840's the Germans began to arrive in large numbers. They were attracted by cheap land, high wages, and the propaganda disseminated by colonization societies in Germany. The Germans settled the area between Houston and Austin, and on another line between Indianola and Fredericksburg. 20

Although most Texans came from former slave states, slavery was disliked as a matter of principle by the Germans. They would gladly have seen the institution disappear, but most Germans were content to let the state handle the problem rather than the Federal government. A small minority of the Germans, however, were radical intellectuals, "Forty-eighters," who had fled the abortive revolutions of 1848 in Europe. These men felt a vocal stand against the evil of slavery should be made. The Forty-eighters gathered in San Antonio in 1854 and advocated the complete abolition of slavery through a system of paid compensation in the near future. The Americans in Texas were outraged

${ }^{20}$ Rudolph Leopold Biesele, "The History of the German Settlements in Texas, 1831-1861" (Unpublished Ph.D. dissertation, University of Texas, Austin, 1928), v-vi, 4-5, 8, 12, 14-15, 18, 35; Terry G. Jordan, German Seed in Texas Soil: Immigrant Farmers in Nineteenth Century Texas (Austin, 1966), 42-46; D. W. Meinig, Imperial Texas: An Interpretative Essay in Cultural Geography (Austin, 1969), 49; Felgar, "Texas in the war For Southern Independence," 514. Foreigners composed 20 per cent of the Texas population west of the Trinity River, while that to the east was nearly 100 per cent American. Barnes F. Lathrop, "Migration into East Texas," Southwestern Historical quarterly, LII (1948-49), 13. 
and, in the heat of the moment, erroneously branded all Germans as radicals and abolitionists. 21 The intricacies of Texas politics placed the Germans in a strange position in the late $1850^{\prime} \mathrm{s}$. Because the opposicion party of the state was the anti-foreign Know-Nothing party, the Germans supported the pro-slave Democratic party in most elections. The strong German Democratic vote cost. Houston the gubernatorial election in 1857. Two years later Governor Runnels' poor record on frontier defense and his flirting with the secessionists cost him the German vote. The Germans had shifted their support to Houston, who ran as an independent pledged to action against the Indians and for the Union. The national election of 1860, however, found the Germans voting for John C. Breckinridge, the southern Democratic nominee, because of their antipathy to Federal interference with slavery in the territories. 22

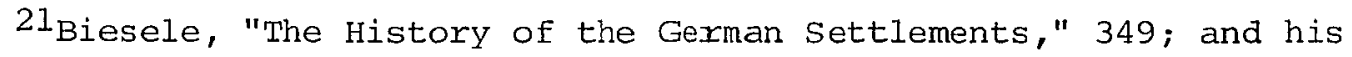
"The Texas State Convention of Germans in 1854," Southwestern Historical quarterly, XXXIII (1929-30), 247-61; Jordan, German Seed, $\overline{181-82 ;}$ Frank Herbert Smyrl, "Unionism, Abolitionism, and Vigilantism in Texas, 1856-1805" (Unpublished M.A. thesis, University of Texas, Austin, 1961), 2-3, 26-74; Egon Richard Tausch, "Southern Sentiment Among the Texas Germans During the Civil War and Reconstruction" (Unpublished M.A. thesis, University of Texas, Austin, 1965), 72 .

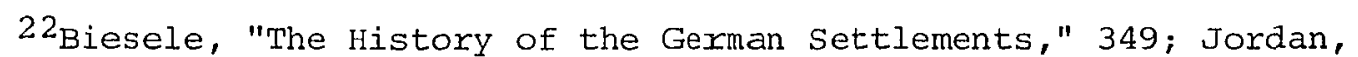
German Seed, 180-81; Smyr1, "Unionism, Abolitionism, and Vigilantism," 4-25; Ada Marie Hall, "The Texas Germans in State and National Politics, 1850-1865" (Unput,iished M.A. thesis, University of Texas. Austin, 1938), 104, 106-107; Ralph A. Wooster, "An Analysis of the Texas know Nothings," Southwestern Historical Quarterly, Lxx (1966-67), 414-23. Wooster finds that the know Nothings were not necessarily anti-foreign. A large portion of them were Unionists or members of opposition parties throughout the state's history. B. H. Epperson, for example, was a Whig, Know Nothing, Houston Independent, Constitutional Unionist, and anti-secessionist, or always opposed to the Democratic hold on the state. See also, Dale A. Somers, "James P. Newcomb: The Making of a Radical," ibid. , LXXII (1968-69), 451-53. 
The vote on secession split the Germans in their sentiment. They did not cast a bloc vote against secession although they tended to support cooperation with the United States. 23 In fact, Union sentiment was stronger in northern counties of Texas along the Red River. Other Unionist support was found in some non-German frontier counties and along the Rio Grande River, where large numbers of MexicanAmericans lived. People were Unionists for several reasons. In northern Texas, about 86 per cent of the population came from northern or border state regions and were lukewarm on secession from the beginning. The western part of the state was populated by the Germans or small nonslaveholding farmers who had no great affinity for the plantation aristocracy that ran state politics. The Indian problem may also have been a factor, but historian Floyd F. Ewing thinks that these settlers felt they would have to defend themselves no matter which nation they were in. This caused the frontier to vote on secession with other factors in mind. Hence, while the German and Red River counties registered their vote against secession, the tier of counties between them voted overwhelmingly for secession. This vote may have been an anti-Negro expression. 24

23Jordan, German Seed, 182-83; Hall, "The Texas Germans in State and National Politics," 107-108. Other European immigrant groups reacted much the same as did the Germans in Texas politics. See Henry R. Maresh, "The Czechs in Texas," Southwestern Historical Quarterly, L (1946-47), 237-38; Oris Emerald Pierson, "Norwegian Settlements in Bosque County" (Unpublished M.A. thesis, University of Texas, Austin, 1947), 64. Texas distrusted the foreign settlers so much after the war, that an attempt to attract other European settlers to the state to replace Negro labor met with serious opposition. See Fred C. Cole, "The Texas Career of Thomas Affleck" (Unpublished Ph.D. dissertation, Louisiana State University, Baton Rouge, 1942), 358.

24 Wallace, Texas in Turmoil, 133; Hughes, Rebellious Ranger, 212; Felgar, "Texas in the War for Southern Independence," $338 \mathrm{n} . \frac{20,515 \text {; }}{20}$ 


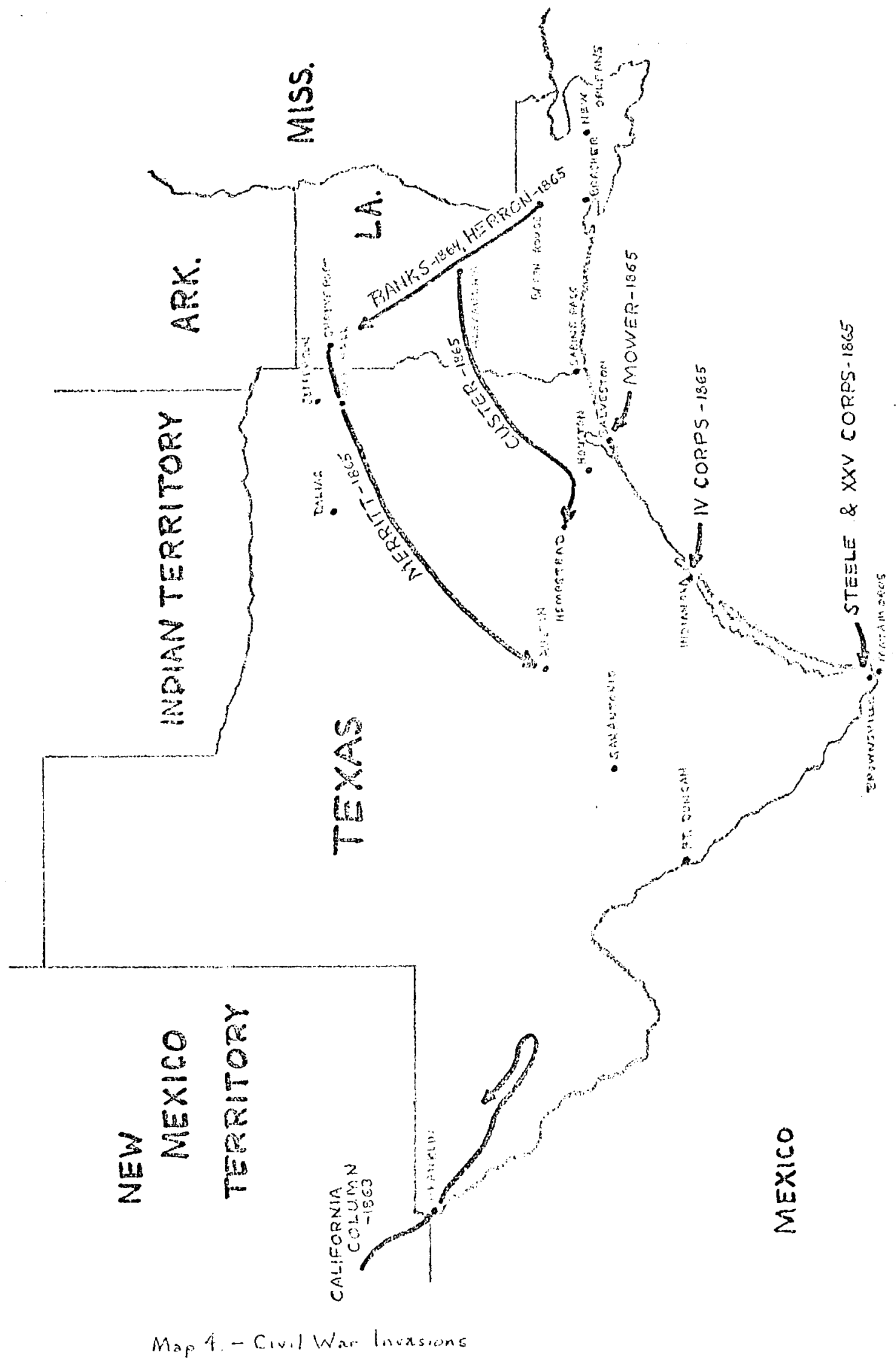


Unionists had three basic courses of action they could take during the Civil War. Many of them swallowed their feelings and joined the Confederate army. This group included many Texas Germans, especially those near New Braunfels. Oftentimes these men joined frontier defense or home guard units to escape confederate service. ${ }^{25}$ Another choice available to Unionists was to stay home and keep silent. 26 Others actively opposed the Confederacy. Most of these persons were forced to flee to the North for their lives, and 1,920 of them joined one of the several Union army organizations raised during the war. 27

Smyrl, "Unionism, Abolitionism, and Vigilantism," 75-100; Tausch, "Southern Sentiment Among the Texas Germans," 59; Jordan, German Seed, 184; Meinig, Imperial Texas, 44; Frank W. Heintzen, "Fredericksburg, Texas, In the Civil War and Reconstruction" (Unpublished M.A. thesis, St. Mary's Iniversity, San Antonio, 1944), ii, 16, 17; Claude Elliott, "Unionist Sentiment in Texas, 1861-1865," Southwestern Historical Quarterly, I (1946-47), 449-77; Floyd F. Ewing, Jr., "Origins of Unionist Sentiment on the West Texas Frontier," West Texas Historical Association, Year Book, XXXII (1956), 21-29. Ewing estimates one out of every three persons was a Unionist in 1861 (21). Wallace, Texas in Turmoil, 132, feels this should be somewhat lower because of those Unionists who sided with the Confederacy later. See also, Charles $w$. Ramsdell, "The Frontier in Secession," in Studies in Southern History and Politics (New York, 1914), 63-75.

25 prominent Texans who chose this course of action were James $w$. Throckmorton, E. W. Cave, and Benjamin H. Epperson. On the loyalty of the Germans to the Confederacy, see Tausch, "Southern Sentiment Among the Texas Germans," 54, 56-58, 60-61, 63-64, 68, 77-78, 88 .

${ }^{26}$ Sam Houston, David G. Burnet, George W. Paschal, and Elisha M. Pease were Unionists who retired from active public life.

27 The Unionists who led the fight against the Confederacy were John Hancock, John L. Haynes (Colonel, Second Texas Union Cavalry), James P. Newcomb, Edmund J. Davis (Colonel, First Texas Union Cavalry), and Andrew Jackson Hamilton (Lincoln's military governor of the state in exile). See Wallace, Texas in Turmoil, 132-33; Felgar, "Texas in the War for Southern Independence," 324; Elliott, "Unionist Sentiment in Texas," 449-52; Brown, History of Texas, II, 441-42. Hughes, Rebellious Ranger, 237, calls those who joined the Union "deserters," 
During the Civil War, Unionist sympathies were often manifested by resistance to the conscription laws. Some Germans even refused to serve in home guard units and held pro-Union political meetings. To chastise them for their errant ways, the state sent Captain James Duff and a company of "partisan rangers" to the Fredericksburg region. Duff ruled the area with a hard hand, and frequently hanged dissident persons. When a band of local young men decided to escape the persecutions by going to Mexico, Duff ambushed and massacred them near the Nueces River. In Burnet County, Unionists were unceremoniously assassinated and dumped into Dead Man's Hole, a deep chasm running several hundred feet straight into the ground. 28

The violence in the German region seemed mild when compared to the internecine warfare then plaguing the Red River counties. Bands

which is not necessarily an accurate label. One company, however, Vidal's Partisan Rangers, did mutiny when called into Confederate service and went over to the Yankees en masse. This and other incidents are described in Frank H. Smyrl, "Texans in the Union Army, 1861-1865," Southwestern Historical Quarterly, LXV (1961-62), 234-50. See also, White, "A History . . of Waller County," 95, 102.

28 Wallace, Texas in Turmoil, 135; Jordan, German Seed, 184-85; Heintzen, "Fredericksburg in the Civil War and Reconstruction," ch. III; Margaret A. N. Goodlett, "The Enforcement of the Confederate Conscript Acts in the Trans-Mississippi Department" (Unpublished M.A. thesis, University of Texas, Austin, 1914), 82a, 83, 85, 87, 89, 90; Malvin George Bowden, "History of Burnet County" (Unpublished M.A. thesis, University of Texas, Austin, 1940), 74; Sara K. Curtis, "A History of Gillespie County, Texas, 1846-1900" (Unpublished M.A. thesis, University of Texas, Austin, 1943), 55-57; Matilda Marie Real, "A History of Kerr County, Texas" (Unpublished M.A. thesis, University of Texas, Austin, 1942), 49; Robert Penni.ger, Fest-Ausgabe Zum 50-jaehrigen Jubilauem der Gruendung der Stadt Friedrichsburg (Fredericksburg, Texas, 1896), 120-22; Robert $w$. Shook, "The Battle of the Nueces, August 10, 1862," Southwestern Historical guarterly, LXVI (1962-63), 31-42. See also, Alwyn Barr (ed.), "Records of the Confederate Military Commission in San Antonio, July 2-October 10, 1862," ibid., LXX (1966-67), 93-109, $289-313,623-44$; ibid., LXXI $(1967-68), 27 \overline{4-78}$. 
of deserters and draft dodgers roamed the river bottoms, fighting pitched battles with the Confederate troops sent to subdue them. Unionist plots were uncovered that resulted in a mass hanging of forty men at Gainesville. The guerrillas were so powerful that the area was nearly lost to the Confederacy. Three men were arrested late in the war for communicating with the Federal commander in Indian Territory and suggesting a United States invasion of the area. 29 When the war ended, the defeated Confederates blamed their subjugation in large part on the Unionists, who were especially hated because of the favor shown them by the victorious yankees. Much of the violence of Reconstruction, especially in northern Texas, grew out of Unionist activities during the Civil War. 30

The final episode that helped influence the way in which Texas was treated during Reconstruction was the mannex in which it surrendered. Because the Federal military commander, Major General Philip H.

29 Even in Austin, the Unionists drilled openly in the streets at the beginning of the war. See Alexander $W$. Terrell, "The City of Austin from 1839-1865," The quarterly of the Texas State Historical Association, XIV (1910-1.1), 120-21; Barkley, History of Travis County and Austin, 88; Goodlett, "The Enforcement of the Confederate Conscript Acts," 92-102; Wallace, Texas in Turmoil, 116, 136-38; Felgar, "Texas in the War for Southern Independence," 387, 516; Rupert N. Richardson, The Frontier of Northwest Texas, 1846-1876 . . . (Glendale, Calif., 1963), 243-44; John Salmon Ford, Rip Ford's Texas, ed. Stephen B. Oates (Austin, 1963), 337-38, 338 n. 2; Reese, "History of Hill County," 127-28; John W. Speer, A History of Blanco County (Austin, 1965), 29; Jewel Pickford Madole, "A History of Salado, Texas" (Unpublished M.A. thesis, University of Texas, Austin, 1952), 27-28; Edith Marian Jordan, "The History of Parker County" (Unpublished M.A. thesis, University of Texas, Austin, 1935), 66.

30 Bancroft, History of the North Mexican States and Texas, 480; Samuel H. and D. H. Fletcher, A History of Co. "A", Second [Illinois] Cavalry (Chicago, 1912), 171-75; Thomas North, Five Years in Texas . . (Cincinnati, 1871), 159-61, 193-94. 
Sheridan, believed a great deal of perfidy accompanied the surrender, he would hold Texans in special contempt and suspicion. Major General Lew Wallace, later the author of Ben Hur, made the first attempt to contact responsible officials in Texas for the surrender of the TransMississippi Department in April of 1865. Wallace had suggested an immediate invasion of the lower Rio Grande Valley to cut off Confederate escape, but President Abraham Lincoln and Lieutenant General U. S. Grant were more worried about ending the war in Virginia first. The President, however, sent Wallace to Brazos Island as a peace commissioner to see what could be done at the moment. Wallace found the local commanders were in favor of surrender, but they refused to move without authorization from higher headquarters. Wallace reported that "the Texas rebels are without heart or confidence and divided amongst themselves." The southern soldiers wanted to go home as soon as possible, said Wallace. 31

While Lew Wallace was making his abortive attempt to secure the surrender of the Trans-Mississippi Department, Major General John Pope, the Union commander at St. Louis, wrote to Grant and proposed a Texas invasion plan. Pope suggested that three columns of cavalry be launched southward from Little Rock toward Shreveport, Kirby Smith's headquarters. Various infantry columns were to move simultaneously up the Red River to hold the Rebels' attention. At a key moment, the three cavalry forces would shift their course to the west, cross the

31 Maj. Gen. Lew Wallace to Maj. Gen. S. A. Hurlbut, April 6, 1865; Wallace to Lt. Gen. U. S. Grant, April 18, 19, 1865, O..R., LXVIII, Pt. 2, 37, 122, 157-58. See also, Robert Ryal Miller, "Lew Wallace and the French Intervention in Mexico," Indiana Magazine of History, LIV (1963), 31-35. 
Red River, and outflank the Confederate defensive line between Marshall and Shreveport from the western side. The outmaneuvered southerners would then have to fight on ground of the Yankees' own choosing. Pope proposed to supply the movement by allowing the Cherokee to raid the frontier ranches in Texas for cattle, which would be driven eastward to the battle site. The victorious Yankees would then march on Houston, living off the land as they traveled, and destroy any remaining Confederate forces. Pope figured he could do the job with 30,000 men.32 Pope was momentarily diverted from his plan by the northward movement of some Missouri troops who had decided to desert Kirby Smith's army and return home, but he soon received Grant's authorization to gather the soldiers and supplies necessary for the move. Major General Joseph J. Reynolds, who became the commander of Texas in 1867, complained that his VII Corps area in Arkansas could not support the large number of men Pope required. Pope evidently had learned much from his defeat by Robert $\mathrm{E}$. Lee at Second Manassas in 1862, for he began to have a few misgivings of his own over the long overland supply route necessary for the movement. He wrote Grant again and offered to cooperate in any alternate plan Grant might devise. On May 19, Pope received notice that Major General Sheridan would handle the Texas invasion, and his plan was quietly tabled. 33

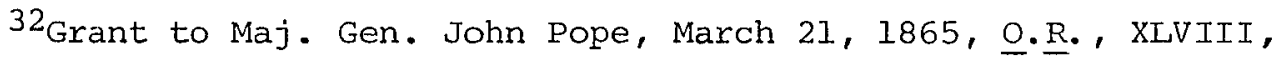
Pt. 1, 64; Pope to Grant, April 8, 1865, ibid., Pt. 2, $\overline{50}-53$.

33pope to Grant, April 10, 21, May 19, 1865; Pope to Brig. Gen. Cyrus Bussey, April 11, 1865; Bussey to Pope, April 11, 16, 1865; Grant to Pope, April 16, 1865; Pope to Maj. Gen. J. J. Reynolds, April 20, 1865, all in ibid., Pt. 2, 64, 69, 70, 106, 107, 138-40, 150-51, 505-506. 
Even before Kirby Smith decided to surrender, his army began to melt away. The most controversial role in the breakup was played by the Texans. As early as October 1864, when it was becoming obvious that the demise of the Confederacy was just a matter of time, Edward R. Hord introduced a resolution into the Texas state legislature. This resolution proposed that Texas never surrender or allow the Union to be reconstructed. Other ominous signs came from far-off New Mexico Territory in May 1865, when Brigadier General James H. Carleton learned that bands of Texas marauders and guerrillas might plunder his command area. Carleton sent dispatches to El Paso and Fort Sumner, ordering the post commanders to treat any captured raiders as outlaws not entitled to the rights of prisoners of war. The guerrillas failed to materialize, but one mo:e suspicious mark was added to the Texas ledger in Washington. In North Carolina, Terry's Texas Rangers refused to surrender to Major General William T. Sherman's army, and began the long trek homeward a day early to avoid capture. Some of its members completed their journey safely, and never did legally capitulate. This and other incidents caused the Federal officer in charge at Vicksburg, Mississippi, to warn his subordinates to exercise the utmost caution in accepting the surrender of Dick Taylor's Confederate army. Disbanded Texas troops were expected to attempt to escape across the Mississippi River and prolong the war. 34

34Elliott, "Unionist Sentiment in Texas," 477-78; N. H. Davis to Capt. D. H. Brotherton, May 4, 1865; Brig. Gen. J. H. Carleton to Brotherton, May 9, 1865; Carleton to CO, Ft. Sumner, May 11, 1865; AAG to CO, U. S. Forces, Big Black River, May 7, 1865; Maj. Gen. N. J. T. Dana to AAG, May 8, 1865, in O.R., XLVIII, Pt. 2, 339, 346, 376-77, 412 ; J. K. P. Blackburn, "Reminiscences of the Terry Rangers," Southwestern Historical Quartexly, XXII (1918-19), 172-73; Lester N. Fitzhugh, "Terry's I'exas Rangers," (Typescript of an address given to the Houston Civil War Round Table, March 21, 1958 in the Louisiana State 
In Texas, Judge Thomas J. Devine, an ardent Secessionist, proposed that a Southern Rights Association be formed of "good and true men determined not to desert the cause in its hour of misfortune, and not to permit others to betray it." The Association met on May 18, in San Antonio. It was resolved that the disasters in the Cis-Mississippi Confederacy would not be accepted as the end of organized resistance in the South, and that absentees should return to their units which were to fight on, backed by the entire resources of the Trans-Mississippi Department. As Thomas North, a Yankee who had lived a harried life in Texas during the war, remarked, "Texas was never whipped in spirit, only nominally whipped, in being surrendered by the official act of General E. Kirby Smith." North marveled how "the proposition was seriously made and entertained, . . that Texas could carry on the war by herself, and alone win what the whole South had failed to achieve together." 35

The senior officer of the Confederate army in Texas, Major General John Bankhead Magruder, defiantly refused to surrender and called for the maintenance of a bold front of disciplined troops in the field. The San Antonio News printed an article that asserted that no "sare man" could consider surrender without approving all of the obnoxious laws passed in Washington since 1861. The News concluded, "death is far preferable," but the men in the field felt otherwise.

University Library), 18.

35 Mary Owen Meredith, "The Life and Works of Thomas Jefferson Devine" (Unpublished M.A. thesis, University of Texas, Austin, 1930), 39-40, 42-43, 71-72; North, Five Years in Texas, 102-103; Works Progress Administration, Houston: A History and A Guide (Houston, 1942), 79 . 
They had had their fill of war. A Louisiana officer felt that few of the men would retreat into Texas and fight on. Already the Missourians remaining in Kirby Smith's army had begun to drift homeward, and they were soon joined by the other troops. Kirby Smith seemed caught in the middle between the die-hards and the realists. 36

Kirby Smith finally decided to act. On May 26,1865 , he surrendered the last organized army of the Confederate States of America to Major General Edward R. S. Canby at New Orleans. According to the terms agreed on, the men were to be paroled until. exchanged or released from their parole, all public property accrued to the United States, all private property was secured to the officers and men, and the troops were to go home and remain there undisturbed unless they violated United states laws. The surrender included all soldiers and sailors of the Confederacy west of the Mississippi River. Within the next few days, the blockade fleet along the Texas coast reported that the port defenses were being abandoned so rapidly that Admiral $H . K$. Thatcher felt safe in reducing the size of his fleet, even though the blockade was still in effect. 37

36 Thomas Affleck to Charles Powers, May 10, 1865; Affleck to John Andrews, May 23, 1865, in Thomas Affleck papers, Department of Archives and Manuscripts, Louisiana State University, Baton Rouge; Maj. William H. Thomas to Maj. John Reid, May 19, 1865, John Reid papers, ibid.; San Antonio News, May 26, 1865; Maj. Gen. P. J. Oster.haus to Maj. Gen. E. R. S. Canby, May 19, 1865, in …‥, XLVIII, Pt. 2, 502.

37 The surrender may be traced in the following: Canby to Grant, May 25, 31, 1865; Terms of Surrender, May 26, 1865; G0 61, May 26, 1865, Military Division of West Mississippi, all in ㅇ..‥, XLVIII, Pt. 2, 591, 600-602, 604-606, 692; Maj. Gen. Gordon Granger to AAG, May 24, 1865; Acting Rear Adm. H. K. Thatcher to Capt. B. F. Sands, May 25, 1865; Thatcher to Secretary of the Navy, May 25, 1865; Thatcher to Canby, May 26, 1865; Canby to Thatcher, May 26, 1865; Maj. Gen. J. B. Magruder to Sands, May 27, 1865; Gustava Fox to Thatcher, May 31, 
At the same time that Kirby Smith surrendered, Governor Murrah at tempted to secure separate terms for the state of Texas. He sent Colonel Ashbel Smith, and a civilian, William P. Ballinger, to talk to Canby about the political situation that faced the state. Murrah hoped they could avoid a Yankee invasion and occupation and obtain recognition of the present state government as the de facto authoxity in Texas. Canby impressed Ballinger as being honest and sensible but he politely refused to negotiate any political issues. While his commissioners were in New Orleans, Murrah issued three proclamations. He called for a special session of the state legislature in July and an immediate election to name delegates to a convention, which was to harmonize relations between Texas and the United States. The remaining proclamation commanded all civil and military officers to preserve and secure public property. 38

Murrah, realizing that he no longer had any control of events,

1865; Thatcher to Canby, May 31, 1865; Canby to Thatcher, May 31, 1865; Thatcher to Maj. Gen. N. P. Banks, May 31, 1865; Circular, June 2, 1865; Thatcher to Secretary of the Navy, June 8,1865 , all in Official Records of the Union and Confederate Navies in the War of the Rebeliion (26 vols., Washington, 1894-1922), Series 1, XXII, $\overline{196}-\overline{97}, \overline{198}, 199$, 202, 206, 209, 210-11, 216-17, 273. See also, Ramsdel1, Reconstruction in Texas, 27-40.

${ }^{38} \mathrm{Gov}$. Pendleton Murrah to Col. Ashbel Smith and W. P. Ballinger, May 24, 1865, Governor's papers (Murrah), Texas State Library, Austin; Flake's Tri-Weekly Bulletin, June 10, 1865; Smith and Ballinger to Canby, May 29, 30, 1865, ……, XLVIII, Pt. 2, 648-49, 675-76; James Lyle Hill, "The Life of Jüğge William Pitt Ballinger" (Unpublished M. A. thesis, University of Texas, Austin, 1937), 42-43; RamsdelI, Reconstruction in Texas, 36-37; Wallace, Texas in Turmoil, 142; AmeriCan Annual Cyclopaedia (1865), 786; Brown, History of Texas, II, 429; Louis J. Wortham, A History of Texas From Wilderness to Commonwealth (5 vols., Fort Worth, 1924), IV, 364; Philip H. Sheridan, The Personal Memoirs of Philip $\mathrm{H}$. Sheridan (2 vols., New York, 1888), II, 230-31. 
fled to Mexico where he died two months later. During the next three weeks, until the arrival of the first United states forces, Texas drifted aimlessly in complete chaos. Dejected Texas troops roamed the countryside. The soldiers degenerated into disorganized mobs that broke into arsenals, and took arms and ammunition before going home. Fifteen thousand armed men were reported organizing at Marshall, determined to continue the war. J. O. Shelby led a cavalry column of three thousand men to Mexico and exacted tribute from each Texas town he passed through on the way. 39

When Sheridan, who had missed the surrender negotiations, arrived in New Orleans, he was outraged at the conditions in Texas. He regarded Kirby Smith's capituation as a "swindle," and charged the Confederate commander of giving up only to secure terms for the weary Arkansas, Louisiana, and Missouri troops in his army who did not wish to fight anymore. The Yankee commander asserted that the surrender "bore upon its face double dealing on the part of the rebel commander, or his agents. . . " Kirby Smith had known the Texans had already gone home, he said, and "their constant boast" was that "they were not conquered and that they would renew the fight at some future date." Sheridan was not alone in his disgust and distrust of the Texans. Thomas North believed the surrender was the root cause for most of the troubles in Texas during the whole Reconstruction period. The Texans felt that they had put one over on the Yankees. They had never been defeated during the war, and now they had avoided the surrender. "Con-

${ }^{39}$ Ramsdell, Reconstruction in Texas, 33-41; Wallace, Texas in Turmoil, 139-41; Carl Coke Rister, Border Command: General Phil Sheridan in the West (Norman, 1944), 15-16. 
sidered in the light of a necessary evil, as a terrible educator, or rough civilizer for the barbarian element in Texas society," said North, "it might have been a good thing" to have made a "Sherman's March" across the state to prove who had really won the war. 40 To make sure Texas knew who the real victors were, General Sheridan decided to invade the state with an army of 50,000 men. "This may seem the employment of a large force to you," he wrote his superiors, "but it is always best to go strong-handed."4l The time had come for Texas to bow to the conqueror's will, and the Yankees were taking no chances. If the Texans wanted a fight to the finish, Phil Sheridan would gladly accommodate them.

40 Sheridan to Grant, June 28, 1865, U. S. Grant papers, Library of Congress; Sheridan to Brig. Gen. John A. Rawlins, June 4, 1865, November 14, 1866, in O.R., XLVIII, Pt。2, 297-98, 767; North, Five Years in Texas, 102-104. North's comment was seconded by William E. Strong, the inspector general of the Freedmen's Bureau. See strong to Maj. Gen. 0. O. Howard, January 1, 1866, in House Executive Documents, 39 th Cong., lst Sess., No. $70,311$.

${ }^{41}$ Sheridan to Rawlins, June 4, 1865, ……, XLVIII, Pt. 2, 767; Sheridan, Personal Memoirs, 210-11. 


\section{A BREACH OF FAITH}

The new Federal commander of Texas, Philip H. Sheridan, began his Civil War career as a captain of the Thirteenth Infantry, and ended it as a major general. Standing only five feet six inches tall, he was a barrel-chested, muscular man whom contemporaries described simultaneously as the "best natured, and most belligerent" person they had met. Born of Irish immigrant parents in either Massachusetts, New York, or Ohio (all of which proudly claimed him), "Little Phil" was raised near Zanesville, Ohio, and received his appointment to west Point in 1848. At the Point, he nearly ruined his career when he attacked a fellow cadet with a bayonet during a heated argument. Fortunately he was overcome by a sudden flash of reason and only beat the other student with his fists, but the incident forced the Academy to suspend him for nine months. Finally graduated thirty-fourth in his class, Sheridan went to Fort Duncan, Texas, as a brevet second lieutenant. He soon received a permanent commission, and was transferred to the Fourth Infantry in Washington Territory where he served as a first lieutenant in the Yakima War in the mid-1850's. By 1861 he was a captain stationed at Jefferson Barracks, Missouri.l

${ }^{1}$ Francis B. Heitman, Historical Register and Dictionary of the United States Army, From Its Organization, September 29, 1789 to March 2, 1903 (2 vols., Washington, 1903), I, 881; C.W. Denison, Il $\overline{\text { Ius }}$ trated Life, Campaigns, and Public Services of Philip H. Sheridan (Philadelphia, 1865), 25-29, 33, 35; Proceedings of the state Assembly of the State of New York, on the Life and Services of Gen. Philip H. Sheridan, As Held at the Capitol, April 9, 1889 (Albany, 1890), 13-22, 
Like many other career officers, Sheridan found himself a colonel of volunteers during the Civil war. He advanced to major general and division command in the Army of the Cumberland, where he fought valiantly at Stone's River, Chickamauga, and Chattanooga. Impressed with the dapper, little Irishman, U. S. Grant took Sheridan east with him in 1864 as chief of cavalry in the Army of the Potomac. Sheridan whipped the lethargic horsemen of the Eastern Theater into shape by cutting away their excess baggage, equipment, and do"nothing officers. Then he proceeded to destroy forever the cavalry advantage held by J. E. B. Stuart's southern cavaliers, killing stuart in the process. 2

After Grant had bottled up the Confederates at Richmond and Petersburg, he sent Sheridan north to stop Jubal Early's raid on Washington. Energetic Little Phil rot only turned Early back, but completely routed the Confederate army in a series of battles during which the Yankees methodically destroyed the productive capacity of the rich Shenandoah Valley. Rejoining Grant for the Appomattox campaign, he led the attacks and pursuit that destroyed the Army of Northern Virginia and ended the bloody four-year conflict. At Five Forks the ever-controversial sheridan sacked the commanding general of the $\mathrm{V}$ Corps, G. K. Warren, for not following orders and replaced him with Major General Charles Griffin, whom he placed in command of the

29-30; Rister, Border Command, 7.

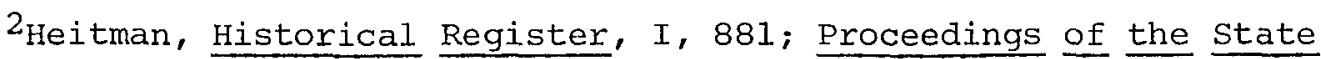
Assembly of the State of New York, 22-48; Rister, Border Command, 8 . 
District of Texas two years later. ${ }^{3}$

In 1865 Sheridan was easily the most popular Union general of the war, next to Grant and Sherman. Because of his close association with Grant in the Eastern Theater, it was natural for Grant to turn to him as the troubleshooter who would force the still-defiant Texans to their knees. Before Sheridan departed, Grant told him that the Army was to control civil affairs in the South until Congress could meet and take appropriate action. Grant hoped in vain that military control "would not only be economical and simple, but would give the Southern people confidence, and encourage them to go to work, instead of distracting them with politics." 4

To assist him in subduing the Trans-Mississippi Confederacy, Sheridan received 12,000 men from the Department of Arkansas, 5 an additional 25,000 men from the Department of the Gulf, the IV and XXV corps, and about 9,000 cavalrymen. The size of this army indicated the difficulty of the task assigned to Little Phil. To facilitate the command structure of the area, Grant created the Military Division of the Southwest with headquarters at New Orleans. This mili-

3 For the 1864 campaign, see Clifford Dowdey, Lee's Last Campaign (Boston, 1960); Edward Steere, The Wilderness Campaign (Harrisburg, 1960); Frank A. Vandiver, Jubal's Raid (New York, 1960); Edward J. Stackpole, Sheridan in the Shenandoah: Jubal Early's Nemesis (Harrisburg, 1961); for the Appomattox Campaign, see Burke Davis, To Appomattox (New York, 1959). An interesting analysis of Sheridan is in Russell F. Weigley, "Philip H. Sheridan, A Personality Profile," Civil War Times Illustrated, VII (1968-69), 5-9, 46-48.

${ }^{4}$ Sheridan, Personal Memoirs, II, 209.

${ }^{5}$ The VII Corps (Department of Arkansas) troops wexe later refused by Sheridan, so 4, June 7, 1865, Printed Orders, Military Division of the Southwest, R.G. 94, National Archives. 
tary division included all of the territory west of the Mississippi and

Arkansas rivers. 6

Grant ordered sheridan to direct his attention first to obtaining the surrender of the only active confederate army left in the field. This army was commanded by Lieutenant General Edmund Kirby Smith who had his headquarters in the Shreveport-Marshall area. Kirby Smith was to be given the same terms as Robert E. Lee and Joseph E. Johnston, provided he surrendered his forces at once. Should Kirby Smith decide to fight on, his soldiers were to be declared outlaws. After the Confederate capitulation, Sheridan was to place troops in the major coastal cities of Texas and occupy the Red River up to Shreveport. In any event, he was to position a corps along the Rio Grande immediately to cut off any Confederate escape and to worry the French who had occupied Mexico in $1861 .^{7}$

Even before Sheridan arrived to take personal command of the Military Division of the Southwest, troop movements had begun to

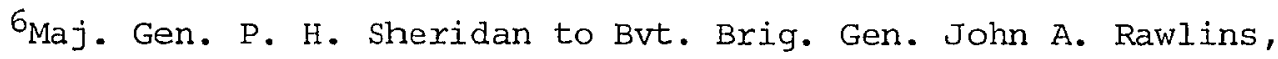
November 14, 1866, O.R., XLVIII, Pt. 1, 297-98. See also Sheridan, Personal Memoirs, II, 208-209; GO 1, May 29, 1865, Printed Orders, Military Division of the Southwest. Sheridan's staff is listed in GO 2, June 1, 1865, ibid. Little Phil's area of control was modified several times before the Reconstruction Act of March 2, 1867 established the Fifth Military District (Louisiana and Texas). These changes included the Military Division of the Southwest (Texas, western Louisiana, southwestern Arkansas), June 1865-July 1865; the Military Division of the Gulf (Florida, Louisiana, Arkansas, Texas, Indian Territory, Mississippi), July 1865-August 1866; the Department of the Gulf (Florida, Louisiana, Texas), August 1866-March 1867. See Lt. Gen. U. S. Grant to Sheridan, July 6, 1865, Grant papers; George W. Cullum, Biographical Register of the Officers and Graduates of the U. S. Military Academy at West Point, New York, From Its Establishment March 16, 1802, to the Army Reorganization of 1866-1867 (2 vols., New York, 1868), II, $35 \overline{6-57}$.

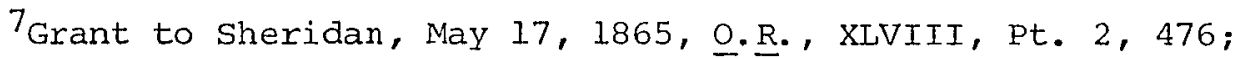
Sheridan, Personal Memoirs, II, 208-209. 
ensure the attainment of these objectives. On May 9, 1865, Major General Gordon Granger, commanding general of the XIII Corps, received orders to concentrate his men at Mobile and to prepare a sea expedition to secure an unnamed "fortified part of the Gulf." Granger carried out his instructions even though a shortage of troop ships made it difficult to move his men. By June 3 Granger's corps had been assigned to Sheridan's command, and Little Phil dispersed it to several areas of the southwestern confederacy. 8

One division of the XIII Corps under Major General F. J. Herron went up the Red River and secured Shreveport. At the same time Herron sent the Eighth Illinois Infantry into Marshall, Texas. Herron discovered that the stampeding Rebels had ignored the pleas of their officers and pillaged public stores before they disbanded in confusion. Meanwhile, as bewildered Negroes flocked into the Union army camps to learn about freedom, the worried citizens welcomed the Federal troops in the hope that they would restore order. 9

Another part of Granger's corps, Major General Frederick Steele's division, was transported to Brazos Santiago near the mouth of the Rio Grande. Steele's men were sent up the river valley to Brownsville. Later, after the XXV Corps arrived from Virginia, steele's command moved up the river as far as Roma, a small village just above Rio

${ }^{8}$ Sheridan to Rawlins, November 14, 1866, O.R. , XIVIII, Pt. 1, 297-98; C/S Military Division of the Southwest to Maj. Gen. Gordon Granger, May 9, 1865, ibid., Pt. 2, 301-302; Maj。Gen. E. R. S. Canby to Rawlins, May 16, 1865, ibid., 456; so 150, June 3, 1865, Military Division of the Southwest, ibid., 745.

${ }^{9}$ Sheridan to Rawlins, November 14, 1866, ibid., Pt. 1, 298; Maj. Gen. N. P. Banks to AAG, May 30, 1865, ibid., Pt. 2, 677; Maj. Gen. F. J. Herron to $A A G$, June 16, 18, 1865, ibid., 903, 918. 
Grande City. They were to block any retreating Confederate columns and restore the authority of the United states to the border region, at the same time posing a direct threat to the French forces at Matamoros by giving arms to the Mexican nationals under Benito Juarez. 10

The remaining division of the XIII Corps landed at Galveston under the command of Major General Joseph A. Mower. These men secured that port, Houston, and the railroad line to Millican and Brenham. Other units were sent to Liberty and Columbus, and detachments of Yankee soldiers visited smaller communities for periods of up to ten days to "benefit. . . the cause of loyalty, safety, and industry." Major General Granger had accompanied Mower to Galveston, where he set up the headquarters of the District of Texas; Sheridan had placed the XIII Corps commander in control of all National troops in Texas. 11 In addition to the XIII and XXV corps, the IV Corps from Tennessee was sent to Texas and positioned along a line between Indianola and San Antonio. 12

The Union troops sent to the old Southwest were sullen and disappointed. Most of them were three-year veterans who felt that they had served their time and wanted to go home with the rest of the men in the northern armies. The troopers of the Second Illinois

${ }^{10}$ Sheridan to Rawlins, November 14, 1866, ibid., Pt. 1, 298-99.

${ }^{11}$ Ibid., 298; Sheridan to Granger, June 10, 1865, ibia., Pt. 2, 841; AAG to Col. F. W. Moore, June 19, 1865, ibid., 931; Bvt. Maj. Gen. C. C. Andrews to AAG, July 11, 1865, ibid., 1078; Cullum, Biographical Register, II, 133-35.

${ }^{12}$ Grant to Maj. Gen. George H. Thomas, May 19, 30, 1865, Rawlins to Thomas, Jurse 22, 1865, O. R.., XLIX, Pt. 2, 837, 931, 1023; Sheridan to Rawlins, July 3, 1865, GO 1, september 10, 1.865, Central District of Texas, ibid., XLVIII, Pt. 2, 1042, 1223-24. The IV Corps was the first unit to leave Texas, ibid., 1242 . 
Cavalny were never told why they were going to Texas and, to them and other disheartened soldiers, the trip was a pure waste of time. "I'm sure I cannot see why they send us to Either [sic] of the above places [Galveston or Brownsville]," wrote one disconsolate soldier. "I know of no need for us there." Others accused the government of a "breach of faith" for holding them in service beyond the end of the war, and they insisted that they were "entitled to a certain share of the justice and gratitude" of the nation. A Connecticut officer, who had served his country for the duration, now wanted "to take up my duty to my dear ones." This same homesick soldier claimed that one of his fellow officers was so cruel to his company that the officer should have served in the Confederate army. When the XXV Corps arrived from Virginia, one man, in shocking despair, wrote of the "contrast between our camp on the banks of the James River, and the camp in this far off, God-for-saken town of Brownsville, Texas." Another soldier met an officer who had been on extended duty in Texas, and who "had not seen a white man besides his own company for two years."13

To men in such poor spirits, the trip to Texas was a nightmare of cramped ship holds and constant seasickness. Often the vessels exploded, caught fire, or hit a snag and sank. The steamboat of the Second Illinois Cavalry caught fire three times between New orleans

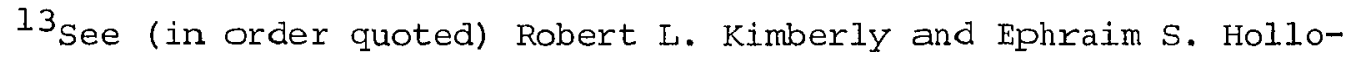
way, The Forty-first Ohio Veteran Volunteer Infantry in the War of Rebelition, 1861-1865 (Cleveland, 1897), 110; Fletcher and Fletcher, Second [Illinois] Cavalry, 166-67; J. R. Cressinger to his father, June 22, 1865, J. R. Cressinger papers, Archives, University of Texas; Clark, Opdycke Tigers, 393; Army and Navy Journal, III (August 26, 1865), 10; Alexander Heritage Newton, Out of the Briars, An Autobiography and Sketch of the 29th Regiment of Connecticut Volunteers. . . (Philadelphia, 1910), 81-82; Oliver willcox Norton to his sister, July 8, 1865, in his Army Letters, 1861-1865 . . (Chicago, 1903), 269. 
and Baton Rouge. Such incidents led some troopers to suspect southern sabotage. After surviving enemy bullets in countless battles, seeing one's comrades drown in the muddy Mississippi or the azure Gulf was too much for veteran bluecoats. As the soldiers' mood grew uglier, the officers restricted them to the ships, fearing the rowdy, ill-tempered men might get out of hand ashore, or refuse to reboard the vessels. 14 The Texas voyage was not helped any by a blistering summer sun and inadequate water condensers that usually provided only half of a ship's needs. The inhabitants of the "deserted and desolate" coastal towns sought to capitalize on the Yankees' plight by selling water at $\$ 1.00$ per canteen, thus prompting the Twenty-ninth Illinois Infantry to confiscate the wells at bayonet point.15 To prevent further incidents, the Federal troops received orders to cook rations ahead of all movements, and they were prohibited from foraging for extra supplies. As an extra safeguard, all arms were ordered stacked and none of the

14 Richard T. Fulfer, A History of the Trials and Hardships of the Twenty-fourth Indiana Volunteer Infantry (Indianapolis, 1913), 130 ; Kimberly and Holloway, Forty-first ohio, 111; Fletcher and Fletcher, Second [Illinois] Cavalry, 163, 169-70; J. R. Cressinger to his father, June 22, 1865, Cressinger papers; Clark, Opdycke Tigers, 393-95; Army and Navy Journal, III (August 26, 1865), 10; Newton, Out of the Briars, $\overline{78 ;}$ Norton to his father, June 15, 1865, Axmy Letters, 262-6 . The homeward trip was much happier, but it was also marred by wrecked ships, heavy seas, and southern belles who would not associate with "nigger officers" of the United States Colored Infantry. See Asbury I. Kerwood, Annal.s of the Fifty-seventh Regiment of Indiana Volunteers (Dayton, Ohio, 1868), 319; Robert G. Dill, "The Soldiers' Homeward Voyage, A Thrilling Experience at the Close of the Late Civil War," Magazine of American History, XI (1884), 445-53.

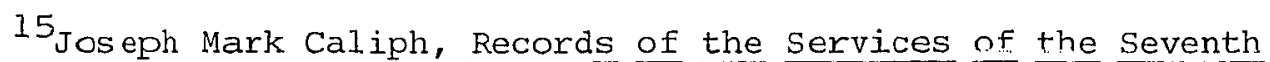
Regiment, U. S.C.T. . . . (Providence, 1878), 73; Army and Navy Journal, III (August $26, \overline{1} 865), 10$. The Mexicans at Bxazos santiago were smarter than the Anglos up the coast. They sold their water for 10 cents a canteen without incident. Newton, Out of the Briars, 78-79. 
volunteer regiments were issued ammunition unless they were on guard duty. Units that persisted in committing "depredations" were sent back to the bleak, sandy coast where there was nothing to be destroyed. 16 Once the troops arrived in Texas, their distress and hardship had hardly begun. The appeal of the warm, dry climate and the fascination of the strange horned toad ${ }^{17}$ soon gave way to a stifling boredom. Sergeant J. R. Cressinger of the Forty-first Ohio wrote his father that his unit was obviously lost, and he sarcastically commented that the government was rumored to have offered "\$100,000 reward for the apprehension of said regiment." The homesick sergeant grimly concluded that the regiment would be in Texas at least three years longex, and by the time he received a "Dear John" letter from his fiancee, Cressinger was too tired to care. 18

The men in the other regiments experienced the same disillusionment. In an effort to arouse some enthusiasm at Galveston, the 125th Ohio Infantry organized a marble tournament. Most men whiled away their time by watching the muster-out lists for their numbers, all the time growing more and more homesick; there was also occasional guard

16 Unnumbered Orders, Third Division, IV Corps, July 4, 1865, O..R., XLVIII, Pt. 2, 1047-48; AAG to [Maj. Gen. Thomas J. Wood], August 6, 1865, ibid., 1169-70. Sheridan felt dissatisfaction over slow muster-out led to many assaults on military equipment assigned to the troops, Sheridan to Grant, October 7, 1865, Grant papers.

$17 \mathrm{~J}$. R. Cressinger to his father, July 13, 26, 1865, Cressinger papers; Norton, Army Letters, 277-79. Norton, unlike most soldiers, enjoyed himself even in a hell-hole like Ringgold Barracks, and began to sign his letters to his sister "Don Olivero."

${ }^{18}$ Cressinger to his father, July 13, August 16, September 6, 1865, Cressinger papers. 
ducy and some hired out as day laborers for local citizens. 19 The lack of activity in the Ninety-fourth Illinois camp is revealed in the diary of William Macy. Usually an avid recorder of events, Macy's last regular entry is May 16, 1865. After that date he mentioned nothing except the muster-out of his own and a neighboring unit in mid-July. 20 The Seventh United States Colored Troops organized a few dances, but these social affairs, especially where officers of black regiments were concerned, did not attract many of the local belles. ${ }^{21}$ Bored, with few regular duties, and cut off socially from the local citizens, the Yankee soldiers hoped to find solace in their letters from home; but the inadequate mail service soon broke down and ended even this outlet from the perpetual ennui. 22 One of the results of this pathetic state of activity was a great susceptibility to sickness. Like many of his comrades from other regiments, sergeant Cressinger fell victim to "chill fever," but he mysteriously improved when his regiment received its muster-out notice. For hundreds of Union soldiers,

19 William C. Holbrook, A Narrative of the Officers and Enlisted Men of the Seventh Regiment of Vermont Volunteers, From 1862 to 1866 (New York, 1882), 205-207. The Seventh was the last Vermont regiment to be mustered out. See also Fulfer, Twenty-fourth Indiana, 131; Kerwood, Fifty-seventh Indiana, 317-18; Fletcher and Fletcher, Second [Illinois] Cavalry, 166; Clark, Opdycke Tigers, 400, 407; Newton, out of the Briars, 80 .

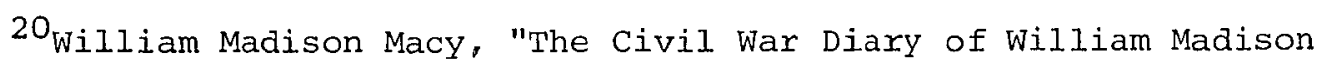
Macy," Indiana Magazine of History, XXX (1934), 197.

${ }^{21}$ Caliph, Records of the Services of the Seventh U.S.C.T. . , 75-76. It was not until January 1866 that Caliph's regiment sponsored a dance with "fair" attendance.

${ }^{22}$ Clark, Opdycke Tigers, 405. Not only did letters fail to arrive, but there was a shortage of postage stamps in Texas. J. R. Cressinger to his father, August 16, 29, September 6, October 5, 1865, Cressinger papers. 
however, the proper "medicine" arrived too late to save them from the grave. 23

Matters were not helped any by the inefficient muster-out system used by the Army. The high command, in an effort to be fair, often discharged veterans who had served the longest time before shipping the remainder of the short-termers to Texas. To keep companies at full strength, the reduced regiments were combined, reorganized as battalions, or filled with new recruits. The loss of unit designation caused a severe morale problem, especially when half the company got to go home, leaving the remaining soldiers to serve out theix enlistments with strangers. 24

The staggered muster-out method was the initial cause of the mutiny of the Forty-eighth Ohio Infantry Battalion. Formerly a full regiment, this unit was reconstituted from elements of the old Fortyeighth, the Eighty-third, and the ll4th Ohio regiments. The battalion served at Houston and Galveston and saw regiment after regiment leave for home while it performed continual guard duty. Although their muster-out orders had arrived many times, they had been postponed repeatedly. By February 1866, the growing sullenness of the unit led the post commander to order the battalion to drill at least once a day

${ }^{23}$ Cressinger to his father, October 5, November 19, 1865 , Cressinger papers; Kerwood, Fifty-seventh Indiana, 317; Clark, Opdycke Tigers, 404; Caliph, Records of the Services of the Seventh U. S. C..T..' $79-80$.

24 Even the brigades that had served together were broken up and only part of their regiments was sent to Texas, all of which angered and dismayed the men. For examples of partial muster-outs, see Fletcher and Fletcher, Second [Illinois] Cavalry, 163; Kerwood, Fiftyseventh Indiana, 316; Clark, Opdycke Tigers, 389, 391; So 25, July 18, 1865, Printed Orders, District of Texas. 
in individual soldier, company, and battalion exercises, and the officers were forced to attend leadership classes with daily recitations. The Articles of War were read to the battalion once a week, and a daily dress parade was to be held unless prevented by "a severe storm." The Forty-eighth followed orders for one month and then, on March 20, stacked arms and refused to serve another day. Major General Horatio G. Wright, who had replaced Granger as district commander, had the battalion's colonel arrested for insubordination. BY March 22 Flake's Bulletin, a Galveston Unionist sheet, reported that the problem had been solved and the battalion had been "thoroughly reconstructed." Before proceedings could be instituted against the mutineers, General Grant intervened, released their colonel from arrest, gave everyone an honorable discharge, and sent the outfit home. 25

While the infantry was struggling with its problems along the Texas coast, Sheridan was assembling an overland expedition of some 9,000 cavalrymen in the Red River Valley of Louisiana. Under the overall command of Major General Wesley Merritt, the cavalry was divided into two columns. One, headed by Merritt, assembled at Shreveport, while the other, under Major General George A. Custer, gathered at Alexandria. Merritt's column was to travel to San Antonio via

${ }^{25}$ The record of the battalion is in Frederick H. Dyer, $\mathrm{A}$ Compendium of the War of the Rebellion ( 3 vols., New York, 1959), III, 1519. See also AAG to CO, Post of Galveston, February 26, 1866, Letters Sent, Central District of Texas, R.G. 393, National Archives; Flake's Bulletin (Galveston), March 20, 22, May 11, 1866; Grant to Sheridan, April 10, 1866, Grant papers; Sheridan to Maj. Gen. H. G. Wright, April 10, 1866, P. H. Sheridan papers, Manuscripts Division, Library of Congress. 
Marshall and Austin, while Custer's marched a parallel course 100 miles to the east, winding up in Houston. 26 The cavalry would provide mounted support within marching distance of the Rio Grande, give mobility to the Union forces in east Texas, and counter the Rebel sentiment in northeast Texas by a show of force. As Custer's wife, Elizabeth, put it, "All I knew was, that Texas . . was unhappily unaware that the war was over, and continued a career of bushwacking and lawlessness that . . . must now cease." 27

Although General Custer looked forward to the laurels he hoped to win in a campaign against either Maximilian or the unrepentant Rebels, the men in the saddles behind him found their new orders to be "a sore disappointment," and they expressed their "outspoken dissatisfaction" with them. 28

Rounding up eleven regiments of horsemen proved to be a complicated and frustrating task for sheridan. Grant gave him a blank check. on any cavalry regiment he wanted, but Major General George H. Thomas was hard put to corral the scattered regiments in Tennessee that

${ }^{26}$ For the command structure, see so 249 , May 22,1865, AGO, o. XLVI, Pt. 3, 1193, 1195; GO 4, June 9, 1865, Printed Orders, Military Division of the Southwest. Sheridan assembled the columns in northern Louisiana because the lower part of the state was too swampy. Sheridan to Grant, June 5, 1865, Grant papers.

${ }^{27}$ Elizabeth B. Custer, Tenting on the Plains, or General Custer in Kansas and Texas (New York, 1887), 31. General Fred Steele especially needed cavalry to patrol the border area and intercept retreating Confederates. Steele to Sheridan, July 8, 1865, Sheridan papers. See also, Grant to Sheridan, June 3, 1855, O. R., XIVIII, Pt. 2, 743 .

${ }^{28}$ Charles Henry Lothrop, A History of the First Regiment Iowa Cavalry . - (Lyons, Iowa, 1890), 216 ; Jay Monahan, Custer: The Life of General George Armstrong Custer (Boston, 1959), $25 \overline{1-52}$. 
Sheridan requested. 29 Because of the inevitable explosions and groundings, the steamboats took until July 12 to transport all the men to Louisiana. To kill time during the trip, the troopers tested their carbines on the numerous alligators basking on the riverbanks. 30

Merritt finished organizing his column several weeks before Custer, and because of the unsettled conditions along the Rio Grande, Sheridan ordered him to move without waiting for Custer's division. 31 Compared to the trouble that Custer had to put up with, the lack of problems in organizing, moving, and stationing Merritt's column is truly noteworthy. But then, unlike the flashy Custer, Wes Merritt was a topnotch, professional soldier, who called attention to himself by the quality of his deeds, not the quantity of his stunts. ${ }^{32}$ The most serious problem that Merritt faced with his sullen, western cavalrymen occurred when one of his brigade commanders held a gala officers' janquet. The enlisted men, who had subsisted on "salt horse," hardtack, and coffee (when they could get it) were outraged at the lavish menu. "Mysteriously" hundreds of small tin cans loaded with black powder were

${ }^{29}$ Grant to Sheridan, June 3, 1865, O.R., XLVIII, Pt. 2, 743; Sheridan to Rawlins, June 8, 1865, Grant papers; Sheridan to Grant, June 8, 1865, O.R. , XLVIII, Pt. 2, 813; Rawl ins to Thomas, June 9, 1865, ibid., XLIX, Pt. 2, 972-73; Sheridan to Rawlins, June 10, 1865, Grant papers; Rawlins to Thomas, June 15, 1865, Brig. Gen. William D. Whipple to Rawlins, June 15, 1865, O..…, XLIX, Pt. 2, 997.

30 Thomas Sydenham Cogley, History of the Seventh Indiana Cavalxy Volunteers . . . (Laporte, Indiana, 1876), 159-63; Lothrop, First Iowa Cavalry, 216-17. See also, Sheridan to Rawlins, July 10, 1865, Sheridan papers.

${ }^{31}$ Sheridan to Maj. Gen. Wesley Merritt, July 5, 1865, Sheridan papers.

32 Merritt's military record is in Heitman, Historical Register, I, 706. 
buried around the church that housed the dinner table. The party had hardly begun when the air was filled with sharp explosions. After several rounds of attempted eating, explosions in the yard, and useless inspection of the ranks for missing men, the banquet was cancelled. Merritt could take a hint. 33

On July 9 "boots and saddles" was sounded, and Merritt's column of 5,500 horsemen began its six-hundred-mile journey. Sheridan proudly reported that the division was "the finest which has marched during the war." The troopers suffered from the heat, which was "like the blast from a furnace," especially during the one hundred miles before Austin. Thirty days after leaving Shreveport, the column arrived in San Antonio. Merritt had allowed no straggling, and $h$ is provost marshals rode in the rear of each unit to keep the ranks closed up. It was a model march, with little to attract attention except the long columns of horse soldiers that stretched back for miles in the hot summer sun. ${ }^{34}$ While Mexritt's cavalry column sweated its way to San Antonio, General Custer was having a problem organizing his five regiments at Alexandria. George A. Custer was the type of man that one either loved or hated with a great deal of passion. He had a knack for doing everything with a flair, from riding into the muddy Chickahominy during the Peninsular Campaign to prove it could be forded, to having

${ }^{33}$ Fletcher and Fletcher, Second [Illinois] Cavalry, 164-65.

${ }^{34}$ Information on Merritt's column is in ibid., 165-66; Sheridan to Granger, June 29, 1865, O..…, XIVIII, Pt. 2, 1026; Flake's Daily Bulletin (Galveston), July 13, 15, 31, 1865; Dallas Herald, August 5, 1865; Galveston Daily News, August 11, 1865. Merritt was about ten days behind his anticipated schedule. See A. R. Roessler to A. J. Hamilton, June 21, 1865, Governor's papers (Hamilton). 
his horse run away with him in front of the reviewing stand during the Grand Review at the end of the war. His death at the Little Big Horn eleven years later proved one thing--George Custer could even die in style. During the Civil War, Custer's flamboyancy helped mold the cavalry arm of the Army of the Potomac into a real power. His men loved his long yellow hair, his non-regulation black velvet uniform, the yards of gold braid, and the pure guts of the man on and off the battlefield. 35

But all the adulation ended at Appomattox. These western cavalrymen just did not care about staying in the army, going to Texas, or George Custer and his style. "He had no sympathy in common with the private soldier," wrote the historian of the Seventh Indiana Cavalry, "but regarded them simply as machines created for obeying his imperial will. Everything about him indicated the fop and dandy." The Seventh Indiana felt that Custer was interested only in his own vanity and gaudy uniforms, and they were not alone. The First Iowa Cavalry, which had served since 1861, remembered the Texas episode only too well. Their historian called it "an ordeal which never fell to the lot of any other body of men during the rebellion." It was a time of "abuse, wanton neglect, base slanders, and atrocious outrages," he concluded, "by one invested with 'brief but misplaced authority. "36

${ }^{35}$ For Custer's career, see Heitman, Historical Register, I, 348. A good personal description of him is in J. H. Kidd, personal Recollections of a Cavalryman with Custer's Michigan Brigade in the Civil War (Ionia, Michigan, 1908), $1 \frac{\text { 29-32. }}{2}$

${ }^{36}$ Cogley, Seventh Indiana Cavalry, 164-65; Lothrop, First Iowa Cavalry, 217 . 
Part of the problem concerned Mrs. Custer's presence with her husband. Libby Custer enjoyed being with the general and "roughing it" in the field. But her consort made sure that his wife had plenty of help when she wanted it, and he detailed soldiers from the ranks to wait on her. This was contrary to regulations and the men hated it. They felt that they had enlisted to be soldiers--not maids. While at

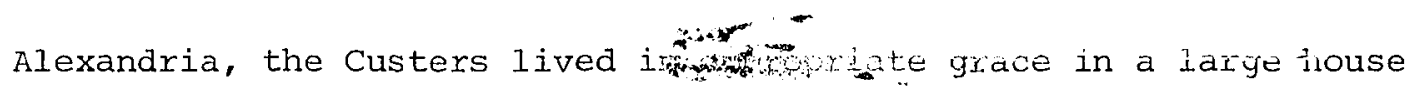
shared with the original owners. Mrs. Custer never saw the family, "and naturally concluded they were not filled with any joy at our presence." The many "nursemaids" frequently needed to staff so large a house and keep up the proper social functions of a general's wife were not "filled with any joy" at the Cuscers' presence either. ${ }^{37}$ Another problem that quickly arose concerned discipline. Custer was from the snappy Army of the Potomac, but his men were western soldiers who had served under Sherman and Thomas or in the forgotten fields of the Gulf South. They were just not classy enough for the natty, golden-haired, wonder-boy general. They had a nasty habit of asking "why?" after they were given direct orders. Custer might have let well enough alone but he decided to straighten out his sloppy crew. The only problem was that these men had three years of service behind them, and were not about to change these ingrained habits during their remaining few months in the army. Custer was adamant, however, and decided to make an example of two recaptured deserters. The whole command was formed around three sides of the parade ground to watch their execution. At the last moment, Custer commuted the sentence of 
one man, while the other was shot by a firing squad. Then each regiment was marched by the dead body to allow the lesson to sink in. 38

Custer was also very strict about other incidents. In his General Orders No. 2, June 24, 1865, he threatened to shave the heads of unauthorized foragers and give them twenty-five lashes, "well laid on." The troopers, who liked to raid plantation smokehouses (the "Rebs" had lost the war anyway), lodged vehement protests with their commanding officers. Later, when rations failed to arrive in Texas, two men of the Seventh Indiana killed a beef for sustenance. When its owner filed a complaint, Custer's provost, "a brute perfectly willing to do his dirty work," found the meat in the men's tent, and gave them forty lashes apiece with the general's approval. ${ }^{39}$ As one trooper put it, "until after the war had closed and we entered Custer's division, the real hardships of camp life had never stared us in our faces." 40

${ }^{38}$ Custer, Tenting on the Plains, 93-107; Monahan, Custer, 257-58; Lothrop, First Iowa Cavalry, 223; Cogley, Seventh Indiana Cavalry, 165-67. Most troopers felt that guilty men should be punished, but that Custer should have realized that the war was over and that these men were not in the regular Army. Custer also seems to have had a knack for punishing first offenders and not catching the more accomplished wrongdoers.

${ }^{39}$ Cogley, Seventh Indiana Cavalry, 176-77; Lothrop, First Iowa Cavalry, 229-32. Lothrop airs the whole case, complete with documents (243-93). The lieutenant colonel of the regiment allowed the Indiana men to be flogged, but threatened that Custer's "hide will not hold corn, by God!" if he touched an Iowan (233). Lothrop says that Custer ignored the fact that flogging was outlawed as a means of punishment in 1861 (222), but the general felt there was a difference between flogging and "lashes." See his letter to Major --.-. Lee, 1865, in Marguerite Merington, The Custer Story: The life and Intimate Letters of General George A. Custer and His Wife Elizabeth (New York, 1950), 173.

${ }^{40}$ Quoted in Lothrop, First Iowa Cavalry, 218. Another incident frequently mentioned is one in which the Third Michigan Cavalry appeared at an inspection with their uniforms dirty and turned inside out. See Richard O'Connor, Sheridan, the Invincible (Indianapolis, 1953), 280-81; and Frederic F. Van De Water, Glory Hunter: The Life of General Custer 
Anothex complaint against the unpopular general accused him of punishing the men by intentionally withholding rations. Someone in the First Iowa wrote the adjutant general's office in Washington and demanded an investigation. By this time washington wanted the whole Custer affair investigated, and Grant ordered Sheridan to relieve Custer of command if the reports proved true. But Little Phil supported Custer and blamed the whole problem on ill-disciplined troops and their desire to be mustered out which was often exacerbated by "insubordinate" letters from home. 41 Perhaps Libby Custer was closer to the truth when she admitted her husband's impetuous nature made things more difficult than they needed to be. 42

The dissatisfied troopers of Custer's division left Alexandria on August 8, crossed the Sabine River, and entered Newton County, Texas. The same heat and dust that had plagued Merritt's march played havoc with this second column. At night the men camped amid swarms of

(Indianapolis, 1934), 130. The Third Michigan, however, was in Merritt's command, not Custer's. See so 8, June 3, 1865, and so 13, June 18, 1865, Printed Orders, Military Division of the Southwest. Elizabeth Custer claims that the westerners even shot up the tent of an unpopular officer late one night. Tenting on the plains, 95-96.

${ }^{41}$ According to Elizabeth Custer, Sheridan told General Custer to do what was necessary for discipline. Tenting on the Plains, 98 . See also, E. D. Townsend to Secretary of War, October $\overline{2}, \overline{1865}$, Sheridan to Townsend, October 9, 1866, Sheridan papers; Grant to Sheridan, December 14, 1865, Sheridan to Grant, December 15, 1865, Grant papers. Custer claimed he was issued insufficient or damaged rations. See his letter to Major ---- Lee, 1865, in Merington, Custer Story, 172-73. Military discipline was a sensitive problem, and officers were reminded to be aware of false charges and to safeguard soldiers' rights. GO 24, May 2, 1868, Printed Orders, Fifth Military District.

${ }^{42}$ Custer, Tenting on the Plains, 110. See also, Monahan, Custer, 257. Van De Water, Glory Hunter, 133, feels that Custer's brutality stemmed from the fact that he could not understand that others were less strong and stubborn than he. 
rattlesnakes and insects that prevented any real sleep. At the suggestion of General Granger, Custer's march was diverted from Houston to Hempstead, where the grass and forage for the animals promised to be more adequate. On August 25 the weary column dismounted at Hempstead where it stayed until the end of October before moving west to Austin. 43

In contrast to his lack of rapport with the troops, Custer was cordially received and well-liked by the civilian population in Texas. They especially liked the tight rein he kept on his men, his willingness to believe their side of depredation accounts, and his readiness to punish soldier offenders. Custer was also anti-Negro enough to sympathize with the ex-slaveholders' view of their freedmen, whom he warned against idleness. The cavalry camp was located on the Liendo Plantation, and the Custers became quite friendly with its owners, $\mathrm{Mr}$. and Mrs. Leonard Groce. They provided Mrs. Custer with a rocking chair and, when she became ill, brought her into their home and care. In return, Custer kept the big house well supplied with game. In fact, Custer was so popular with the local citizenry, Elizabeth wrote home

${ }^{43}$ Cogley, Seventh Indiana Cavalry, 167-74, 182; Lothrop, First Iowa Cavalry, 239. Custer issued the same orders of march as did Merritt but they were somewhat longer and more detailed. See Go 15, August 7, 1865, in Lothrop, 220-22. For Merritt's orders see Flake's Daily Bulletin (Galveston), July 15, 1865. The horse soldiers, however, would not admit that Custer did anything correctly and condemned close-up marching in the hot sun as stupid. Lothrop, First Iowa Cavalry, 222. Merritt's men marched in the same manner, yet they took their suffering in silence. Fletcher and Fletcher, Second [Illinois] Cavalry, 166. See also, Granger to C/S, July 7, 1865, ……, XLVIII, Pt. 2, 1063; Custer, Tenting on the Plains, 200, 202. The Custer baggage was moved to Austin by civilian contractors who had submitted sealed bids for the task. 
that he could be elected to Congress from Texas were he to run for the office. She still worried about the troopers ("they hated us, I suppose") but their discipline was much improved, and she dismissed their dislike as one of the prices of command. At any rate, it was comforting to be liked by all those fine, hospitable southerners who attended the grand parties the general sponsored. 44

Then the great day arrived! The infantry and cavalry volunteers were going home at 1ast. The muster-out of the numerous Yankee armies had begun shortly after Lee's surrendex at Appomattox, when the Secretary of War, Edwin M. Stanton, halted recruiting and curtailed the purchase of all war supplies. At the end of April 1865, a schedule of troop reduction was envisioned, and by November 1866, all but 11,000 volunteers had been mustered out. There were several exceptions to the schedule, however, and the troops detailed for Texas composed the largest special case of all. 45

The demobilization of the volunteers stationed in Texas was done

${ }^{44}$ Custer, Tenting on the Plains, 108-11, 114, 152-56, 181-82, 224, 229, 245; Elizabeth Custer to her parents, October 22, 1865, in Merington, Custer Story, 171; Monahan, Custer, 258-64; White, "A History of . . . Waller County," 108-109; Leon Mitchell, Jr., "Camp Groce: Confederate Military Prison," Southwestern Historical quarterly, LXVII (1963-64), 15-21.

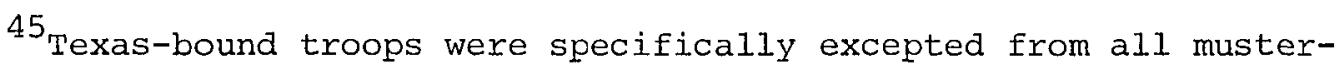
out orders. See GO 96, June 25, 1865, Printed Orders, Department of the Gulf; and "Annual Report of the Secretary of War," House Executive Documents, 39th Cong., 1st Sess., No. 1, 19, 21-28. American Annual Cyclopaedia (1865), 78-79, also lists the demobilization schedule. For a general survey of demobilization, see Ida M. Tarbell, "How the Union Army was Disbanded," Civil War Times Illustrated, VI (1967-68), VI (1967-68), 4-9, 44-47. The general pattern of demobilization was: artillery, cavalry, infantry, troops stationed in the east before those stationed in the west, whites before Negroes, northern and border state Negro troops before Negro enlistees from the deep South. 
THBLE 1

TROOPS MUSTERED OUT IN TEXAS, 1865-1867

\begin{tabular}{|c|c|c|c|}
\hline Month & $\begin{array}{l}\text { Infantry } \\
\text { Regiments } \\
\end{array}$ & $\begin{array}{c}\text { Cavalry } \\
\text { Regiments } \\
\end{array}$ & $\begin{array}{l}\text { Artillery } \\
\text { Batteries } \\
\end{array}$ \\
\hline $\begin{array}{l}\text { 1865/July } \\
\text { August } \\
\text { September } \\
\text { October } \\
\text { November } \\
\text { December }\end{array}$ & $\begin{array}{r}8 \\
5 \\
6 \\
7 \\
17 \\
16\end{array}$ & $\begin{array}{l}1 \\
2 \\
4\end{array}$ & $\begin{array}{l}1 \\
3 \\
3\end{array}$ \\
\hline $\begin{array}{l}\text { 1866/January } \\
\text { February } \\
\text { March } \\
\text { April } \\
\text { May } \\
\text { June } \\
\text { July } \\
\text { August } \\
\text { September } \\
\text { October } \\
\text { November } \\
\text { December }\end{array}$ & $\begin{array}{l}2 \\
5 \\
5 \\
\\
5 \\
1\end{array}$ & 4 & 1 \\
\hline $\begin{array}{l}\text { 1867/January } \\
\text { February } \\
\text { March } \\
\text { Apri1 } \\
\text { May } \\
\text { June } \\
\text { July } \\
\text { August }\end{array}$ & 1 & & \\
\hline TOTAL & 85 & 16 & 9 \\
\hline
\end{tabular}


only on special orders from Washington until the first of August.

Then Sheridan received the power to muster out all the white troops he

did not need. In september Grant ordered him to demobilize as many men "as the service will bear." Sheridan wanted to send home even more than the seven regiments that left that month, but border problems with Maximilian prevented it. By October 1865, all but three regiments of the IV Corps had been sent home. Late in December Sheridan received the authorization to reduce his entire command to 10,000 white and 10,000 black volunteers. On January 7,1866 , Sheridan reported he had 6,500 white volunteers and 19,768 black troops under his command. 46 While the demobilization was a year-long process of anguish for the white volunteers, 47 it was quick enough to worry the military governor of the state, A. J. Hamilton, who wrote a protest to sheridan. Hamilton felt the muster-out would be disastrous to the interests of Unionists and the Federal government. If the Yankees left, "there would occur a scene of violence, and outrages upon the Union men of the state and upon the freedmen, such as to shock the moral sense of

${ }^{46}$ Circ. 39, August 2, 1865, AGO, in "Annual Report of the Secretary of War," House Executive Documents, 39 th Cong., lst Sess., No. 1, 75-76; Grant to Sheridan, September 6, October 28, December 30, 1865, Sheridan to Grant, September 20, 1865, January 3, 7, 1866, Sheridan to Rawlins, October 19, 30, 1865, all in Grant papers.

47 The last nine regiments and one battalion left in May 1866. The First Iowa Cavalry and their despised leader, Custer, were mustered out at the same time (February 1866). One source has the Iowans waving their hats to the numerous friends they left behind. Custer, however, left the night before to avoid a bushwacking party arranged for him by his troopers. A relay of twelve horses kept him ahead of the volunteers, and saved him for the Sioux in 1876. See Lothrop, First Iowa Cavalry, 296-97; Frank Brown, "Annals of Travis County," ch. XXV, 13-14, mss. in Frank Brown papers, Archives, University of Texas. 
the entire country . . . "48 But Sheridan was more worried about the wrath of the disgruntled volunteers who had already begun to destroy public property. The mutiny of the Forty-eighth Ohio Infantry Battalion clinched his desire to get rid of the volunteers and rely on the steady regulars, a feeling Grant heartily concurred with. ${ }^{49}$ As for the volunteers, the San Antonio Herald correctly summed up their sentiments when it said the information on their final discharge "will be glorious news to the white volunteer troops on duty in this vicinity as it seems to be that they have long signed and languished for." 50 Had Grant, Sheridan, or the editor of the Herald known more about the arriving Seventeenth Infantry, they might not have been so eager to see the volunteers replaced. The Seventeenth was one of several three-battalion regiments authorized by President Lincoln in the spring of 1861 when the regular army was expanded to meet war needs. Each battalion had eight companies, or two less than the normal regiment. This meant the regiments numbered from Eleven to Nineteen had twenty-four companies each, or were the equivalent of two and

48 Hamilton's lettex was probably prompted by the muster-out of twenty-three infantry regiments, four cavalry regiments, a cavalry battalion, and two artillery batteries in November and December of 1865 . Hamilton to Sheridan, January 17, 1866, Andrew Johnson papers, Manuscripts Division, Library of Congress. Sheridan initially agreed with the governor.

${ }^{49}$ Sheridan to Grant, October 7, 1865, January 20, 1866, Grant to Sheridan, January 22, 1866, Grant papers.

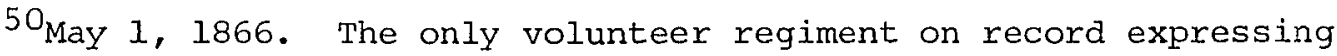
a desire to stay in the service was the First Texas (Union) Cavalry. Its colonel, John L. Haynes, wrote Governor Hamilton that their musterout would be a blow to Unionism and invite atrocities from ex-Confederates. Haynes to Hamilton, August 29, 1865, Governor's papers (Hamilton). The regiment was mustered out a month later. Sheridan to Merritt, September 20, 1865, Sheridan papers. 
one half normal-sized regiments. The Seventeenth had seen much service during the war. It experienced heavy losses on the second day of Gettysburg, and many more at the Wilderness in 1864. So the Army pulled the Seventeenth out of the line for a rest and recruitment. Recruits came hard, however, because most men preferred the lax discipline and large bounties paid enlistees in volunteer regiments. Hence, by 1865, the Seventeenth Infantry was a mere skeleton of its former self, and those who had joined the regiment represented the scum of society. 51

The Army tried to attract good men after the war by offering honorably discharged volunteers a thirty-day furlough with full pay and allowances if they joined the regulars within ten days of their own discharge. But when Grant ordered the regiment to Texas in March of 1866, eight companies were still shorthanded, and three more had been detached to Detroit to stop Irish nationalists from raiding British Canada. Sheridan wrote Washington that receiving less than half the regiment "embarasses me to some extent," but he went ahead with the muster-out of the volunteers. 52

By the end of July 1866 the Army had been reorganized by Congress into forty-five regiments of infantry, ten of cavalry, and five of artillery. The three-battalion infantry regiments were expanded by six companies, and then split apart with each battalion renumbered

${ }^{51} \mathrm{C}$. St. Chubb, "The Seventeenth Regiment of Infantry," in Thomas F. Rodenbough and William L. Haskin (eds.), The Army of the United States (New York, 1896), 637.

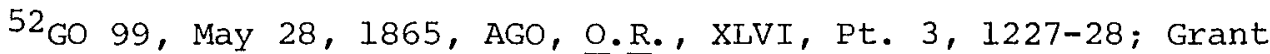
to Sheridan, March 19, April 20, 1866, Sheridan to Rawlins, April 18, 19, 1866, Grant papers. 
as a regiment. The seventeenth Infantry was reorganized into the Seventeenth Infantry (First Battalion), the Twenty-sixth Infantry (Second Battalion), and the Thirty-fifth Infantry (Third Battalion), commanded by Colonels Samuel P. Heintzelman, Joseph J. Reynolds, and Charges Griffin, respectively. Although the new regiments were organized by October 1866, Sheridan was still trying to fill them to full strength as late as January the following year. ${ }^{53}$ Along with the Seventeenth Infantry, three regular cavalry regiments were sent to Texas. These were the veteran Fourth and Sixth regiments, and the Ninth Cavalry, one of two newly raised Negro mounted regiments. The Fourth Cavalry arrived first and camped near San Antonio where it was used to keep order. among the rowdy volunteers nearby. The older men who had served with the regiment during the war were astounded at the quality of the Fourth Cavalry recruits. "It looked like all the worthless element of the mustered out volunteer service had been re-enlisted in the Fourth U. S. Cavalry," commented one trooper. The Fourth was soon sent to the frontier west of San Antonio to put down raids by Indians and desperadoes. 54

${ }^{53}$ Sheridan to Townsend, October 24, 1866, Sheridan to AGO, January 31, 1867, Telegrams Sent, Department of the Gulf records; Col. S. P. Heintzelman to $A A G$, November 23, 1866, Telegrams Received, ibid.; Townsend to Sheridan, October 25, 1866, Sheridan papers; Grant to Stanton, April 10, 1867, Johnson papers; American Annual Cyclopaedia (1866), 32-33; Heitman, Historical Register, I, 113-15, 125-26, 133. The seventeenth suffered heavily from cholera and yellow fevex which sapped its strength. St. Chubb, "The Seventeenth Regiment of Infantry," 638. The regiment remained in Texas until 1869 when it was replaced by the Twenty-ninth Infantry and sent to New York City. Maj. Gen. E. R. S. Canby to Bvt. Col. R. M. Morris, March 4, 1869, Letters Sent, Fifth Military District records.

54 Sheridan to Rawlins, August 21, October 26, November 14, 1865, Grant papers; Sheridan to Grant, November 3, 1865, AAG to Sheridan, December 16, 1865, Sheridan papers; Heitman, Historical Register, I, 
In November 1865, shortly after the Fourth Cavalry had arrived in San Antonio, elements of the Sixth Cavalry were sent northward to Austin. The Sixth had served in the Reserve Cavalry Brigade of the Army of the Potomac, and the whole brigade of six regiments had numbered less than five hundred men at Appomattox. Nevertheless, by that fall the regiment was sent to the Texas capital, where it had a bout with cholera, before it was refitted and placed on the northern frontier in 1866.55

The last regular units to reach Texas were the Ninth (Colored). Cavalry and the Forty-first (Colored) Infantry. ${ }^{56}$ Authorized in July 1866 as two of six new Negro regiments in the Army, they were organized from mustered-out colored volunteers. Like their white brethren, the Negro volunteers had originally disliked the idea of going to Texas in 1865. The cavalry brigade of the XXV Corps mutinied in Virginia and had to be brought under control by a Pennsylvania artillery battalion. 57

70-71; Thomas F. Rodenbough, "The Fourth Regiment of Cavalry," in Rodenbough and Haskin (eds.), The Army of the United States, 216; James Larson, "Memoirs," 217-20, $2 \overline{24,}$ mss. in James Larson papers, Archives, University of Texas.

55 W. H. Carter, From Yorktown to Santiago with the Sixth U. S. Cavalry (Baltimore, 1900), 131-36; Carter, "The Sixth Regiment of Cavalry," in Rodenbough and Haskin (eds.), The Army of the United States, 242; Heitman, Historical Register, I, 72-73. Sheridan wanted mounted orderlies from the Fifth Cavalry because it was stationed at scattered posts after the war, but he was refused and had to detail companies from his own regiments, usually Co. G from the Sixth Cavalry. Sheridan to Grant, December 28, 1865, Grant papers; Carter, Yorktown to Santiago, 136.

56 The Ninth was one of three black regular regiments recruited in Sheridan's district. The others were the Thirty-ninth Infantry, and the Forty-first Infantry. Grant to Sheridan, August 7, 1866, Grant papers; Sheridan to Townsend, August 13, September 1, 1866, Sheridan papers.

57 Theophilus Gould Steward, The Colored Regulars in the U. S. 
Nevertheless, Sheridan believed the colored troops liked the service and, to facilitate recruiting, he recommended thirty-day furloughs for black re-enlistees. The Negro volunteer soldiers, however, appear to have been as bored as their white counterparts, which made the editor of the Galveston Daily News uneasy. When word of their muster-out arrived, the relieved editor breathed "that is something to be thankful for." 58 The black soldiers had some difficulty at first with army discipline. Part of the Thirty-ninth (Colored) Infantry revolted in Louisiana, and the Ninth Cavalry had a rebellion at San Antonio that cost one officer his life and wounded two others and a black sergeant. 59 In spite of preliminary problems, the Ninth was soon stationed along the California trail at Forts Davis and stockton, while the Forty-first (Colored) Infantry garrisoned the Rio Grande posts. ${ }^{60}$ There were, however, to be many months of agonizing problems along the Rio Grande before the border could be entrusted solely to the guard of the Fortyfirst Infantry.

Army - . (Philadelphia, 1904), 86-87, 90; Army and Navy Journal, II (June 17, 24, 1865), 673, 689.

58 Sheridan to Rawlins, June 21,1866 , Sheridan to Townsend, August 24, 1866, Sheridan papers; Galveston Daily News, September 30, 1865, May 17, 1866. The Texans also worried about black volunteers retaining their weapons after they had been mustered out. Sheridan to Rawlins, October 24, 1865, Grant papers.

${ }^{59}$ Bvt. Maj. Gen. Frank Wheaton to AAG, November 11, 1867, Letters Received, Fifth Military District records; Dallas Herald, April 20, 1867.

${ }^{60}$ Sheridan to Townsend, September 1, 1866, Sheridan papers; Sheridan to Rawlins, March 20, 1867, Grant papers; Heitman, Historical Register, I, 75-76, 136; Grote Hutcheson, "The Ninth Regiment of Cavalry," in Rodenbough and Haskin (eds.), The Army of the United States, $280-83$. 


\section{THE LAST ACT OF THE REBELLION}

When General Gordon Granger's disgruntled volunteers had garrisoned the coastal cities of the eastern part of Texas, another army began to arrive and disembark amid the adobe jacals of Brazos Santiago and Point Isabel near the mouth of the Rio Grande. This so-called "Army of Observation" was to be secretary of state William H. Seward's high card in a game of international bluff aimed at ridding Mexico of a Franco-Austrian invasion force and restoring the republican government of Benito Juarez to power. In addition, these troops were to garxison the Rio Grande line and end the continual raiding by large bands of desperadoes on both sides of the river.

The territory between the Rio Grande and Nueces rivers had figured prominently among the causes of the Mexican War, and it had been unstable and tense ever since. Far from either American or Mexican authority, the area became a prime haven for refugees from justice. In 1858, the Governor of Talmaulipas, Ramon Guerra, had established the "zona libre," a six- to eight-mile-wide strip that stretched for five hundred miles north along the river. Within this zone, goods were allowed to circulate freely without being subjected to high Mexican tariffs. Combined with duty-free storage rights on the American side, Guerra hoped to quell the desire of Mexicans to move across the river to take advantage of cheaper American prices. ${ }^{1}$

\footnotetext{
${ }^{1}$ J'Nell Pate, "United States-Mexican Border Conflicts, 1870-
} 


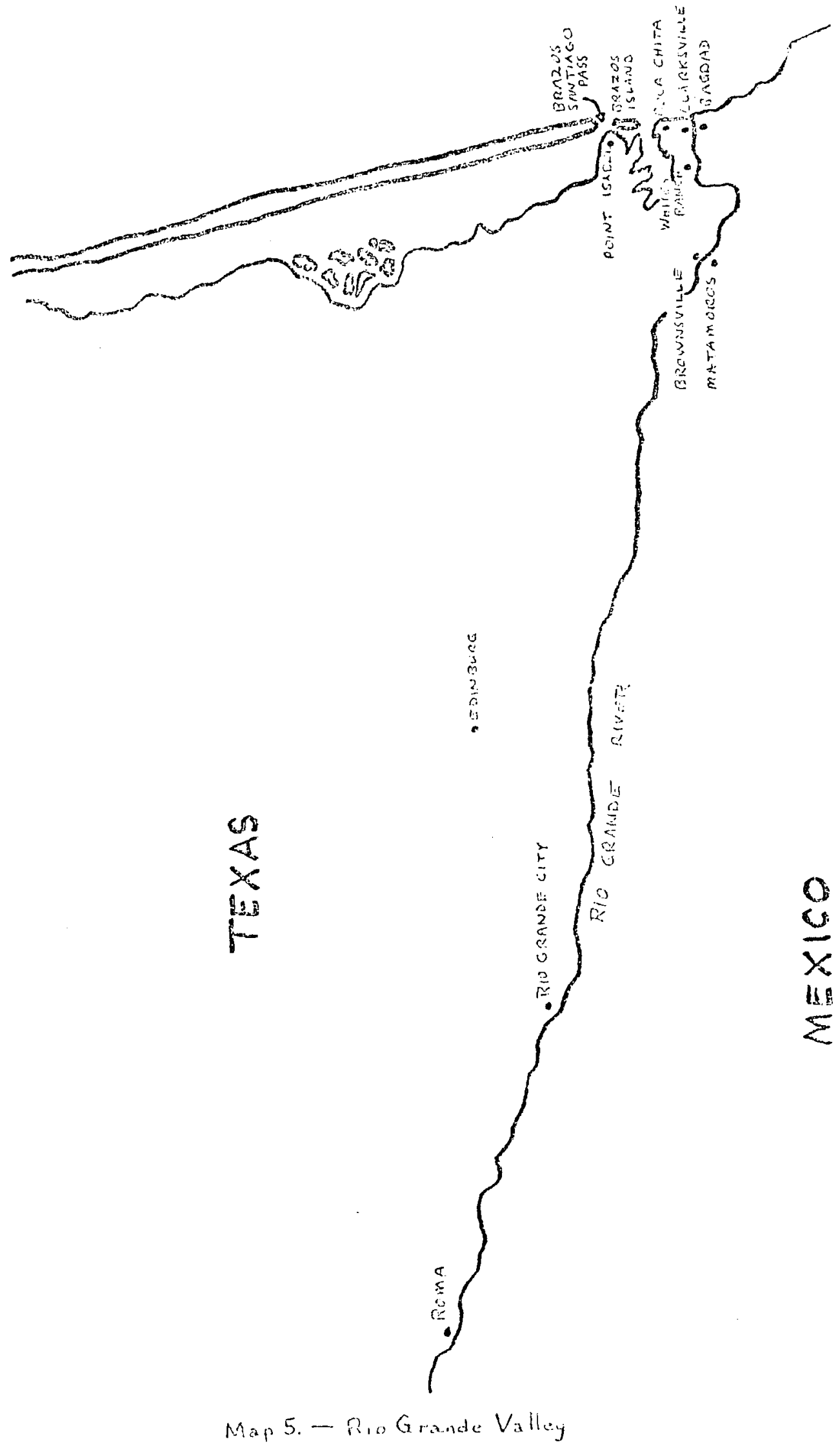


The same year the zona libre was established, tensions between the defeated Mexicans and victorious gringoes exploded into violence that lasted for two decades. Juan N. Cortina, a Mexican citizen whose mother conveniently owned land on both sides of the river, had a quarrel with an Anglo sheriff over who should have custody of one of Cortina's peons who was accused of being drunk and disorderly. As a result of the argument, Cortina and a large band of men rode into Brownsville, freed the prisoner, shot the jailer, and terrorized the town for several days. Many Mexicans flocked to Cortina's banner, and he defiantly flew the Mexican flag over his hacienda on the American bank of the Rio Grande. Ultimately a combined force of local militia, Texas Rangers, and the United States army defeated and scattered cortina's men at Rio Grande City. The Rangers followed up the battle with raids into Mexico at the orders of Major Samuel Heintzelman, the regular army commander at Brownsville. Although minor forays continued, the river valley remained relatively peaceful until a Confederate force made another counterraid in $1863 .^{2}$

The insecurity of the border, and the independent actions of Governor Guerra and Juan Cortina only emphasized the weakened state of the whole Mexican government at this time. By 1865 Mexico had been a free and independent nation for forty years, yet it had had thirty-six

1880," West Texas Historical Association, Year Book, XXXVIII (1962), 181; Barry M. Cohen, "The Texas-Mexican Border, 1858-1867," Texana, VI (1968), 154; Clarence C. Clendenen, Blood on the Border: The United States Army and the Mexican Irregulars (New York, 1969), 20-56.

${ }^{2}$ Cohen, "The Texas-Mexican Border," 154-61; J. Fred Rippy, The United states and Mexico (New York, 1931), 180-85. 
changes of government and seventy-three presidents. ${ }^{3}$ Continual factionalism and bickering between republicans and monarchists marked the period before the American Civil War and set the stage for the European intervention.

The actual pretense for intervention was the debt moratorium of the Juarez government. Juarez had just defeated his monarchist opponents in a three-year civil war in which both sides had invited foreign interference and which had left the country penniless. Now that Juarez had won, the monarchist emigres again appealed to the crowned heads of Europe to aid them in returning to their homeland. The opportunity seemed readily at hand because the United States had just embarked on what promised to be a long civil war. On October 31, 1861, the governments of England, France, and Spain agreed to the Convention of London in which they promised mutual action in Mexico, and withdrew their ministers from Mexico City. ${ }^{4}$

The invasion force of the three allied nations landed at Vera Cruz in January 1862. After much procrastination, the European powers

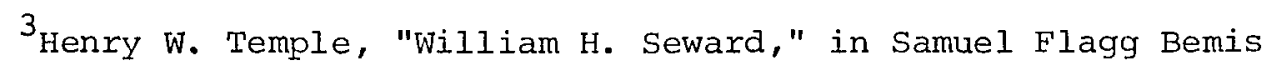
(ed.), The American Secretaries of State and Their Diplomacy (10 vols., New York, 1927-29), VII, 105.

${ }^{4}$ Dexter Perkins feels that the prime goal of the intervention was, in the words of Napoleon III, to halt the spread of the "dangerous utopias and bloody disorders" of democracy. Hand in hand with the antidemocratic crusade was a genuine fear of American expansion as typified by the Treaty of Guadalupe-Hidalgo, the Gadsden Purchase, frequent filibustering expeditions, and President James Buchanan's abortive request to Congress in 1858 for the right to use the United states Army to protect American citizens in Mexico. See Perkins, The Monroe Doctrine, 1826-1867 (Baltimore, 1933), 318-49, 354-56, 36 $\overline{3-64} \overline{367}, \overline{418}$. See also, Jack Autrey Dabbs, The French Army in Mexico, 1861-1867: A Study in Military Government (The Hague, 1963), 18; Egon Caesar Count Corti, Maximilian and Charlotte of Mexico, trans. by Catherine Alison Phillips (2 vols., New York, 1928), I, 113-14. 
signed the Convention of La Soledad, which repeated the earlier assertions made in London--that Mexican sovereignty was not to be threatened by the invasion. At the same time the Mexicans allowed the allied armies to move inland out of the yellow fever zone. The allies also promised to withdraw to the coast should further negotiations break down. The French immediately became obstinate and refused to turn over cextain monarchists to the Juaristas, even though the refugees were Mexican citizens on Mexican soil. The Juaristas immediately stopped negotiating, and when Britain and Spain sided with the Mexicans at the Orizaba Conference in April 1862, France withdrew her forces to the coast, thereby freeing herself from the La soledad provisions. By this time Britain and Spain only wanted a fast but honorable way out, and quickly withdrew their forces, leaving France by itself. The inevitable incident, the alleged mistreatment of three French soldiers in Orizaba, soon occurred. Accordingly the French army did an aboutface and marched on Mexico City, capturing it one year later after a disastrous defeat at the hands of the Juaristas near Puebla. The French commander set up a provisional government which called a national assembly, which in turn offered the throne to Ferdinand Maximilian, Archduke of Austria. 5

When the Archduke accepted the crown as Emperor Maximilian of Mexico in 1864, the position of the liberals was nearly untenable. The most productive and populous parts of Mexico were under French control, and the republicans commanded only the state of Guerrero and the area

5aniel Dawson, The Mexican Adventure (London, 1935), 235-43, 272-82; Wilfred Hardy Callcott, Liberalism in Mexico, 1857-1929 (Palo Alto, Calif., 1931), 46-47; Dabbs, The French Army in Mexico, 23-55; Corti, Maximilian and Charlotte, I, 167-68, 176-80, 210-11, 220-22; Perkins, Monroe Doctrine, 367-96. 
near present day Ciudad Juarez, where the beleaguered president had made his headquarters. Not only did Juarez have to fight the French and their Mexican supporters, but he also had to win over the powerful jefes of each local area, many of whom had leadership ambitions of their own. ${ }^{6}$ This chaotic state of affairs existed in Mexico for the remainder of the American Civil war when several new factors produced an end to Maximilian's ill-fated empire.

One of these factors was the defeat of the Confederate states of America. The Confederacy tended to support Maximilian's Mexican adventure, partly because she desired European recognition in return, but mostly because Matamoros was the one open connection that the TransMississippi South had with the outside world. The Confederates feared that Juarez, as an avowed supporter of Lincoln, would probably shut off this breach in the Yankee blockade. ${ }^{7}$ The demise of the Confederacy changed the whole military position of the Rio Grande frontier. Instead of a border protected by a friendly Confederacy, Maximilian was now faced by a hostile united states that might intervene at any moment on the side of the republicans.

Nor was the United States long in pushing its new advantage. Throughout the Civil War, Secretary of State Seward had had to move gingerly on the Mexican question because of the internal situation

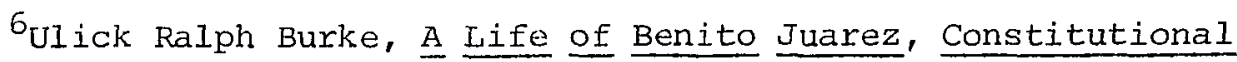
President of Mexico (London, 1894), 252, 270-71; Perkins, Monroe Doctrine, 402-405; Cohen, "The Texas-Mexican Border," 162-63; Dabbs, The French Army in Mexico, 145.

7 Although Lincoln and Juarez never met or corresponded, they had a great deal of sympathy for each other's position. See Leonard Gordon, "Lincoln and Juarez--A Brief Assessment," Hispanic-American Historical Review, XLVIII (1968), 75-80. 
produced by the secession crisis. To have acted too brashly would have forced the French into an alliance with the Confedexacy, while no protest at all would have ended the Monroe Doctrine through inaction. The withdrawal of the British and Spanish fleets, coupled with the warnings of the American minister, John Motley, had given Austria second thoughts about her lukewarm support of the Mexican adventure, but Napoleon III was not to be deterred. By 1864 all of Europe expected the North to win the American Civil War; however, France hoped that by the time the victory was completed Maximilian would be too firmly entrenched in Mexico to be forced out. ${ }^{8}$

Both Napoleon III and Maximilian were to be greatly disappointed in their ambitions. In his orders to Sheridan in May 1865, Grant emphasized the importance of placing a large contingent of troops on the Rio Grande immediately, whether Kirby Smith surrendered or not. In Juiy, Grant told Little Phil to avoid a war with the imperialists, if possible, but nevertheless to render all possible aid to the liberal cause. It would "be better to go to war now," he concluded, "when but little aid given to the Mexicans will settle the question," than to risk a bigger war against an entrenched monarchy at a later date. $^{9}$

To carry out this policy of aiding the Juaristas, Sheridan was given the XXV Army Corps, a veteran Negro outfit then stationed in

8perkins, Monroe Doctrine, 393-94, 412, 415, 416; Temple, "William H. Seward," 106.

${ }^{9}$ Grant to Sheridan, May 17, 1865, O. R., XLVIII, Pt. 2, 746. see also, Grant to Sheridan, July $25,186 \overline{5}$, in proceedings of the State Assembly of the State of New York, 50-51. 
Virginia. Freed by the surrender of the Confederate army at Appomattox, the corps embarked at City Point, Virginia, during the last week of May 1865, and stood out to sea bound for Brazos Santiago.10 Rumors at Maximilian's court placed between 60,000 and 100,000 Americans in Texas, with the greater part of that force headed toward the Mexican border. ${ }^{11}$ In order that the mission of the Army of observation should not be misunderstood, Sheridan ordered General Frederick Steele, who was then in Mobile, to proceed directly to Brownsville with his own division of the XIII coxps and take command of the entire valley district without delay. ${ }^{12}$ Leaving orders at Mobile to forward the XXV Corps, Steele departed for Texas, where Sheridan enjoined him to keep his brigades organized "as a movable column," ready for instant

10 For the movement of the XXV Corps, see Rawlins to Maj. Gen. Henry W. Halleck, May 18, 1865, Grant to Maj. Gen. Godfrey Weitzel, May 21, 1865, Weitzel to Rawlins, May 25, 1865, Brig. Gen. Charles A. Russell to AAG, June 25, 1865, in O....., XLVI, Pt. 3, 1168, 1193, 1225, 1295. The XXV Corps was composed of two divisions and numerous attached troops. A third division of the Corps was in North Carolina but it was never sent to Texas. The first two divisions were later reorganized into three new divisions and placed at Brazos Santiago, White's Ranch, and Brownsville, respectively. See Army and Navy Journal, II (June 10, 1865), 657; ibid., (August 5, $\overline{1865}$ ) 768. Elements of the Corps were also placed at Indianola and Corpus Christi. See Granger to Brig. Gen. R. H. Jackson, June 8, 1865, AAG to Russell, June 25, 1865, so 2, July 4, 1865, District of Texas, Jackson to AAG, July 31, 1865, all in ㅇ..…, XLVIII, Pt. 2, 819, 991-92, 1047, 1140-41.

$11_{\text {For the rumors circulating in Mexico, see Dabbs, The French }}$ Army in Mexico, 149. Of the slightly over 51,000 soldiers sent to Texas, 30,000 were sent to the Rio Grande. See Rawlins to Halleck, May 18, 1865, O.R. , XLVI, Pt. 3, 1168; and Sheridan to Rawlins, November 14, 1866, in "Annual Report of the Secretary of War," House Executive Documents, 39 th Cong., 2nd Sess., No. 1, 48 .

${ }^{12}$ Maj. Gen. E. R. S. Canby to Grant, May 26, 1865, O..R.., XIVIII, pt. 2, 602-603; Grant to Weitzel, May 28, 1865, ibid., XLVI, Pt. 3 , 1230; Canby to Brig. Gen. Fred Steele, June 1, $1 \overline{865}$, ibid., XLVIII, Pt. 2, 716-17. 
action. 13

As quickly as Steele's division and the XXV Corps arrived at Brazos Santiago, they were distributed up the river as far as Ringgold Barracks in an attempt to interdict the escape route of fleeing confederate soldiers and officials. Steele recommended that the river be garrisoned as far up as old Fort Duncan at Eagle Pass; ${ }^{14}$ however, this was not routinely done until March 1868, probably because i.t was too expensive to send volunteers very far inland only to have them shortly mustered out. ${ }^{15}$ Although most of the volunteer army was demobilized within one year after Appomattox, the presence of the Army of Observation did not go unnoticed south of the border. ${ }^{16}$ By December

${ }^{13}$ Sheridan to Steele, June 2, 1865, Sheridan papers. The liberal offensive in the summer of 1865 was planned with the presence of the United States Army along the river in mind. See Mr. M. Dolan to Maj. Gen. S. A. Hurlbut, ApriI 3, 1865, …․, XLVIII, Pt. 2, 17-18.

${ }^{14}{ }_{\mathrm{Maj}}$. Gen. N. P. Banks to Brig. Gen. E. B. Brown, May 10, 1865, O.R., XLVIII, Pt. 2, 381-82; Steele to Sheridan, June 20, 1865, Sheridan papers; Sheridan to Grant, August 1, 1865, Grant papers.

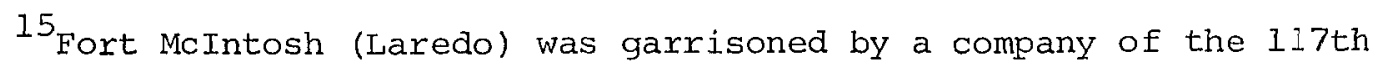
U.S.C.T. in March 1867. It was replaced by the Forty-first (Colored) Infantry by August 1867, which also occupied Fort Duncan the following spring. See Manuscript Returns, District of Texas, R.G. 94, National Archives; and Dyer, Compendium of the War of the Rebellion, III, 1739.

16 Maurice Matloff (ed.), American Military History (Washington, 1969), 282. Of the forty-five regiments and five batteries present on the Rio Grande, eighteen regiments and two batteries were mustered out by December 31, 1865. Twenty-two regiments and the rest of the artillery left the following year. The remaining five regiments were mustered out by August 1867. Grant temporarily stopped the muster-out in March 1866 and allowed Sheridan to retain any general officers he needed as long as necessary. Grant to Sheridan, January 22, March 29, 1866, Grant papers. See also, Perkins, Monroe Doctrine, 489-90. The increase in troop strength which Perkins speaks of (489) in July 1865 is deceptive. It just took this long for the available transportation facilities to move the men. There was no increase beyond the initial assignments. See Sheridan to steele, July 7, 1865, Sheridan papers. 
1865, however, the XXV Corps was so reduced and scattered that it had to be discontinued as a unit and, thereafter, each post reported directly to the commanding general at Brownsville. 17

In spite of the regular reductions made in the strength of the Army of observation, its presence on the border meant that at any moment the slightest incident could lead to a declaration of war by either side. The "very saucy and insulting" attitude of the haughty French officers, who often sent pointed, sarcastic letters to their American counterparts, led to hot verbal exchanges. ${ }^{18}$ But seward was adamant that there should be no provocations from the American side at any time. To insure against any local commander's using undue initiative, Grant wrote Sheridan that only the President, the secretary of state, or he could issue orders on the Mexican problem. Whenever field officers overstepped these orders, they received immediate reprimands. ${ }^{19}$ Grant and Sheridan also sent continual reminders to Texas that strict neutrality was to be maintained along the Rio Grande. 20

Impartiality, however, concerned only overt acts. Covertly

17 Sheridan to Grant, December 16, 1865, Sheridan papers.

$18_{\text {This }}$ attitude was probably caused by the extreme nervousness of the French over the presence of so many American soldiers. Sheridan to Grant, June 28, November 20, 1865, Grant papers.

${ }^{19}$ Seward's desire to bluff the French into withdrawing from Mexico is emphasized by Perkins, Monroe Doctrine, 467, 476, 502, 504. For the order restricting local initiative, see Grant to sheridan, June 19, 1865, Grant papers. For the reprimand of General Brown for undue friendliness with the French, see Sheridan to Steele, June 29, 1865, Sheridan papers.

${ }^{20}$ Grant to Sheridan, July 1, December 1, 19, 1865, Grant papers; Sheridan to Granger, July 5, 1865, Sheridan papers; Grant to Sheridan, July 25, 1865, in Proceedings of the state Assembly of the State of New York, 50-51. 
Sheridan ordered the Army of Observation to insure a Juarista victory by supplying the liberal army with small arms, artillery, ammunition, and other necessary supplies of war. The demobilization of the volunteer troops played an important part in this task. As each unit was mustered out, it left vast quantities of equipment along the Rio Grande. With Grant's consent, Sheridan had the departing troops' arms and ammunition "condemned" or declared as "surplus." Then the Americans cached these implements at strategic points near the river and notified Juarez of their location. At first Juarez was expected to pay cash for the materiel, but his meagre finances were soon expended. Grant then had Sheridan give the equipment to the liberals without insisting on payment. 21

In addition to obtaining supplies for the Juaristas, Sheridan tried to prevent the imperialists from using equipment seized from fleeing Confederate soldiers who crossed the border seeking refuge. All southern military supplies were considered public property, surrendered to the United States, and no transfer of it to Maximilian's supporters was to be allowed. This was one of the main reasons the Army of Observation had extended its outposts up to Ringgold Barracks. Of particular interest to the Americans were several field pieces obtained by General Tomas Mejia, the imperialist commander at Matamoros. Mejia claimed he had no authority to return the equipment and insisted

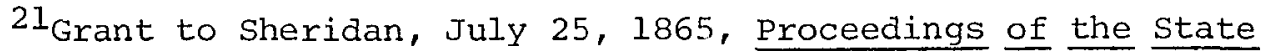
Assembly of the State of New York, 50-51; Grant to Sheridan, October 22, 1865, Sheridan to Rawlins, July 16, 1866, Grant papers; Sheridan to Grant, August 2, 1866, Sheridan papers. See also, Sheridan, Personal Memoirs, II, 224-26; Rister, Border Command, 17-18; O'Connor, Sheridan, 278; Robert Ryal Miller, "Matias Romero: Mexican Minister to the United States During the Juarez-Maximilian Era," Hispanic-American Historical Review, XIV (1965), 235. 
it had been purchased before the surrender of Texas to the Union forces. General steele began a series of demonstrations which, accompanied by a sharp diplomatic protest, convinced Maximilian that the artillery was not worth the trouble it caused. Accordingly he commanded Mejia to return the guns. Steele promptly had them declared as unserviceable surplus and allowed them to fall into the hands of the Juaristas. 22

While the aid rendered to the liberals was substantial in the long run, the methods used by seward vexed many military men, who disliked the "slow and pokey methods of our state Department," as Sheridan put it. In his memoirs sheridan accused seward of being so diplomatic and polite with the French that he nearly cost Juarez the whole struggle during the winter of 1865-1866. Grant sympathized with Sheridan and expressed his own desire to move more forcefully to evict the French, but he realized that it was seward's show to direct. Finally, unable to contain himself any longer, the impulsive Sheridan went to San Antonio to review the IV Corps stationed there. He then took a regiment of cavalry and rode to Fort Duncan where he openly communicated with Juarez's staff. As the diplomatic wires crackled with the news of his exploit, Sheridan smugly returned to New Orleans, satisfied that he had saved Mexico for democracy. ${ }^{23}$

22 Banks to Brown, May 10, 1865, Sheridan to Granger, June 16, 1865, Steele to Mejia, June 28, 1865, Mejia to Steele, June 29, 1865, all in O.R., XLVIII, Pt. 2, 381-82, 902, 1037-38; Sheridan to Grant, July 14, 1865, Grant papers; Sheridan, Personal Memoirs, II, 214; Denison, Illustrated Life, Campaigns, and Public Services of Philip Sheridan, 194.

${ }^{23}$ Sheridan, Personal Memoirs, II, 214-17; Grant to Sheridan, October 22, 1865, O.R. , XLVIII, Pt. 2, 1242-43; O'Connor, Sheridan, 286. It should be pointed out that seward was correct in his "slow 
Grant and Sheridan were not the only Americans who thought more could be done to insure a Juarista victory. In fact, several attempts were made, officially and unofficially, to rendex direct military aid to the liberals. As early as April 1865, before Kirby Smith surrendered, General Iew Wallace arrived at Brazos Santiago and opered communications with the Confederates at Brownsville. Wallace proposed an immediate surrender of the Rebels, to be followed by a joint attack on the imperial forces across the river. The southern troop commanders liked the idea, but it was dropped when higher authorities in Houston Erowned on it. Wallace continued his efforts on the liberals' behalf by accepting an appointment as major general in the Mexican army, sponsoring fund raising activities in northern cities, and raising volunteer units. In an attempt to unite the quarreling jefes under one leader, he also helped sponsor General Jose Maria Carvajal as the leader of the Juarista armies. Sheridan, who felt Carvajal was too old and "cranky," reluctantly organized a personal bodyguard from his scouting unit, but the French intercepted and scattered them as they crossed the Rio Grande. Sheridan believed Wallace's efforts were mostly wasted, but the flamboyant author of Ben Hur publicized the plight of Juarez, forwarded some arms, and stimulated individuals to go south and join the Mexican army. 24

and pokey methods," because he was extremely leery of fighting another conflict so soon after the bloody Civil War. There was some doubt whether the American public would have supported a new war. See Perkins, Monroe Doctrine, 504. For a good summary of Seward's policy, see Rippy, The United States and Mexico, 252-74.

24 On the Wallace efforts, see Miller, "Lew Wallace," 31-50. See also, Sheridan, Personal Memoirs, II, 219-23; Sheridan to Grant, August 15, 1866, Sheridan papers; Perkins, Monroe Doctrine, 469. 
Wallace's exertions were not the only semi-official assistance sent to the liberals. In Galveston, Flake's Bulletin reported that Army officers had little trouble in securing temporary leaves of absence to join the Juaristas. In Brownsville, men could receive up to fifty dollars a month to enlist as "bodyguards" for certain unnamed parties having "business" in Mexico. Filibustering units regularly crossed the Rio Grande, and Sheridan warned his Texas commander to break them up if United States neutrality were affected. The United States colored troops stationed along the border were reported to be greatly in sympathy with the liberal cause, and discharged soldiers regularly crossed south of the line to join Juarez. 25

The enthusiasm the Negro soldiers had for the Juaristas eventually led to the border incident feared so much by Seward. Among the numerous soldiers of fortune who turned up in Brownsville was General R. Clay Crawford, late of the Confederate army and a confidant of Lew Wallace. Sheridan, naturally suspicious of any ex-Rebel, detained Crawford in New Orleans, but Grant assured him that Crawford had "business" in Mexico. Sheridan then allowed the Tennessean to continue his journey. 26 suddenly, two months later, Crawford's name came up again--this time as the leader of an attack on Bagdad, Mexico, near the mouth of the Rio Grande. Worst of all, Crawford's filibusteros consisted mostly of blue-uniformed, Negro soldiers on duty with the Army of Observation. Sheridan was irritated that his emphatic orders

25 Flake's Daily Bulletin (Galveston), January 4, 1866; Sheridan to Maj. Gen. H. G. Wright, January 7, 1866, Sheridan papers; Sheridan to Grant, November 20, 1865, January 12, 1866, Grant papers.

${ }^{26}$ Sheridan to Grant, November 20, 1865, and Grant to Sheridan, November 28, 1865, Grant papers. 
respecting neutrality could be so blatantly ignored. He ordered General Wright to conduct an immediate investigation in person, and sent a hasty message to Major General. Godfrey Weitzel to get his men back to the American shore immediately. 27 Weitzel, who had gone over with more Negro soldiers to arrest Crawford and had remained in Bagdad nearly a week for reasons of "humanity," readily complied. In the meantime, several Juaristas had been freed from jail, and a large quantity of arms was found to be missing from the French arsenal. In an effort to appease the imperialists, Crawford was arrested and his men paroled until called for trial. Fortunately, by this time the French hold in Mexico was so tenuous that they too wished to forget the matter. 28

American intervention in Mexican affairs was not only a touchy issue with Maximilian, but the liberals also were unsure of the intentions of their large neighbor to the north and feared American intervention would cause a Franco-American war that might cost Mexico all chance for independence. The Mexican Minister to Washington, Matias Romero, however, was finally reconciled to accept a plan whereby Americans could volunteer to fight with the Juaristas and receive a

27 Sheridan to Grant, January 16, 17, 22, 1866, Grant to Sheridan, January 25, 1866, ibid.

${ }^{28}$ Grant to Sheridan, February 15, 1866, ibid.; Army and Navy Journal, III (February 10, 1866), 397; Miller, "Lew Wallace, $4 \overline{1-44}$; Dabbs, The French Army in Mexico, 154-55. The incident may be studied in depth by examining File 909A1866, Microcopy 619, Roll 452, National Archives. Crawford "escaped" his captors sometime later and the incident was allowed to lapse without the participants' being tried. Another similar incident occurred in November 1866, at Matamoros, but it created few problems because the Army supported the liberals instead of a local jefe. See Sheridan to Rawlins, December 11, 1866, Johnson papers. 
grant of land in return. After Grant and W. T. Sherman refused the command of the volunteers, Major General John Schofield agreed to head the unit. Seward disliked the international implications of the idea and sent Schofield to Paris, France, to get him out of the way and give Napoleon III something to worry about. When Schofield returned from France a few months later, neither he nor Napoleon had yet figured out what was going on. 29

Aid to Juarez was also preventative in nature. While the United States turned her back to "immigrants" who entered the liberal armies, she was very careful to stop any person or group who might help the imperialists. Sheridan closed off all Gulf ports to anyone heading to Mexico without a pass from his headquarters at New Orleans. When a group of ex-Confederates wished to establish a colony in Maximilian's part of Mexico, Sheridan refused to allow them to board the ship at the Crescent City. ${ }^{30}$ When a filibustering group of four divisions was organized in New York City by "Germans, Irish, and Confederates," Secretary of State Seward promised Matias Romero the expedition would be stopped. 31

29Miller, "Matias Romero," 240-44; Perkins, Monroe Doctrine, 172-75, 500-501. Grant and Matias Romero were both angered by the manner in which seward undercut their plan. Altogether, about 3,000 Americ ins (mostly Yankees) fought with Juarez, and another 2,000 (mostly soutl.erners) fought for the imperialists. Nearly one-fourth of the liberal army was composed of norteamericanos at the decisive battle of Santa Gertrudis, which cleared northern Mexico of Maximilian's forces. See Miller, "Matias Romero," 239; Cohen, "The Texas-Mexican Border," 165; Dabbs, The French Army in Mexico, 172.

${ }^{30}$ For the breaking up of this "Cordova Experiment," see Sheridan to Rawlins, November 14, 1866, O.R., XLVIII, Pt. 1, 297-303; Sheridan, Personal Memoirs, II, 218-19.

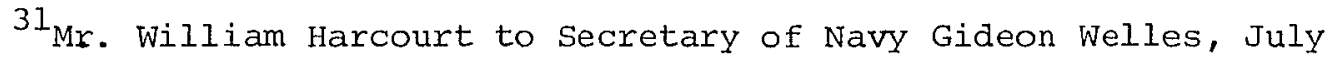
12, 1867, Romero to Seward, July 15, 22, 1867, Sheridan to Grant, 
Nurtured by American supplies, liberal military strength grew, and the French forces were driven into the larger towns by incessant guerrilla attacks. The key city along the Rio Grande was Matamoros, which commanded the main roads between Mexico and Texas and the lower river valley. The town was held by approximately 3,000 imperial troops, 300 of whom were Austrians, but the garrison was under a constant state of siege by a small number of Juaristas who commanded the surrounding countryside. ${ }^{32}$ The effect was a virtual stalemate even though the imperial troops were being starved out gradually. Juarez seems not to have been aware of his strength in northern Mexico, a fact which disgusted Sheriāan, who felt the liberals should be more aggressive. Fearful of rumors that the "willy-nilly" state Department might desert the Juaristas, Sheridan warned Grant to block such moves. Finally the liberals captured a large supply column carrying over a million dollars in military goods and eleven pieces of artillery. The I news dismayed the garrison of Matamoros. It marched south en masse giving the city to Juarez on June $24,1866.33$

After the fall of Matamoros, the whole imperialist position in Mexico crumbled. Sheridan worried that the French army might be trapped, thus forcing Napoleon to send more troops to relieve it, but

July 17, 1867, Seward to Romero, July 23, 1867, and Andrew Johnson to the House of Representatives, House Executive Documents, 40 th Cong., 2nd Sess., No. 25, 1-6. $163-64$.

${ }^{32}$ Denison, Sheridan, 193-94; Cohen, "The Texas-Mexican Border,"

${ }^{33}$ Sheridan to Grant, August 18, 1865, Grant papers; Sheridan to Grant, September 26, 1865, Sheridan papers; Sheridan to Grant, september 28, 1865, June 24, July 3, 1866, Johnson papers. See also, Dabbs, The French Army in Mexico, 171-72. 
his fears proved groundless. The fleeing French outmarched their pursuers. ${ }^{34}$ The greatly improved position of the Juarez government convinced Seward that the United States should make formal contact with the liberals. Accordingly he appointed Major General John Logan as the American minister to Mexico in November 1865. Later, in the following spring, Logan was replaced by Lewis D. Campbell who was given orders to find Juarez, hasten French withdrawal, and not to interfere in the quarrels between rival liberal factions. 35

Accompanied by Major General William T. Sherman, ${ }^{36}$ Campbell set sail in November 1866, for Vera Cruz. Since the French controlled the harbor, he declined to land but learned through agents that Juarez was believed to be at San Luis Potosi in the mountains north of Mexico City. Campbell then put into Tampico, a post held by the Juaristas, where he heard that Juarez was still in Chihuahua somewhere instead of San Luis Potosi. 37 Campbell decided that Matamoros would be a more convenient headquarters, and upon arrival was told by the local commander that Juarez would be in Monterrey on December 20. The American minister was about to depart overland to Monterrey but reported that

\footnotetext{
${ }^{34}$ Sheridan to Rawlins, July 21, 1866, Grant papers.

35 Pexkins, Monroe Doctrine, 494, 499-500; Seward to Campbell,
} May 21, October 25, 1866, House Executive Documents, 40th Cong., lst Sess., No. $30,4-7$.

${ }^{36}$ Sherman went along as a military advisor. Grant was initially given the position but, as commanding general, he declined to leave Washington. See Grant to Johnson, October 21, 1866, Grant to Stanton, October 27, 1866, Stanton to Grant, October 30, 1866, House Executive Documents, 40th Cong., 2nd Sess., No. 57, 72-73.

${ }^{37}$ Seward to Campbe11, November 9, 1866, Campbell to Seward, November 23, December 1, 1866, ibid., 40th Cong., lst Sess., No. 30 , $9,12,16-17$. 
he did not know with which group of rival Juarista bands to cooperate. He also feared capture by French forces en route. So, on Seward's suggestion, Campbell retired to New Orleans to let "events ripen in Mexico."38 When Juarez asked Campbell to come and be received, the latter procrastinated and ultimately resigned on June 15, 1867, ostensibly because of an illness in his family. It remained for his successor, Marcus Otterburg, the former U. S. Consul at Vera Cruz, to establish relations with the liberal government. 39

The hopelessness of Maximilian's empire was obvious after November 1865. The French Assembly was unhappy about the use of French troops in Mexico, Maximilian was rapidly retreating upon Mexico City, and Juarista strength was increasing. In addition, the whole Rio Grande was in liberal hands, which meant supplies could flow into Mexico freely from the United States. Napoleon reluctantly accepted the facts. The French and American governments agreed to a three-phase withdrawal beginning in November 1866. The rest of the French troops would be pulled out of Mexico in March and November 1867, although the Americans believed all the French forces would leave in the fall of 1866. When the French slowed their withdrawal to the agreed on timetable, they assured the United States that the delay was due only to

${ }^{38}$ Campbell to Seward, December 13, 24, 1866, January 7, 1867, ibid., 19-20, 23, 31. For a good discussion of this mission, see Martin H. Hall, "The Campbell-Sherman Diplomatic Mission to Mexico," Historical and Philosophical Society of Ohio, Bulletin, XIII (1955), 254-70.

${ }^{39}$ Campbel1 to Seward, December 24, 1866, February 9, 1867, Senor Lerdo de Tejada to Campbel1, April 22, 1867, exchange between Campbell and W. H. and F. W. Seward, June $3,5,6,15,16,1867$, W. H. Seward to F. W. Seward, June 21, 1867, all in House Executive Documents, 40th Cong., ist Sess., No. $30,25,41,63-64, \overline{71-72,74-75,} 76$. 
winter weather, and all forces would be removed by spring 1867. Maximilian at first panicked and announced his abdication, but his Mexican supporters managed to talk him out of his one brilliant idea in the whole unfortunate intervention episode. 40

Although Napoleon III refused to force Maximilian off the throne, the rapid exodus of the French arny in the spring of 1867 left the Emperor of Mexico at the mercy of the liberals. 41 The Emperor hurried an army northward to Queretaro where Juarez finally cornered him and forced his surrender. 42 Ignoring American appeals for mercy, the Juaristas executed Maximilian before a firing squad on June 19, 1867.43

Seward's game of bluff, as enacted by Sheridan and the Army of Observation, had been eminently successful. As Sheridan put it, "it is but the end of the rebellion which had its commencement in this

40 Seward to Campbell, October 25, 1866, ibid., 40th Cong., 2nd Sess., No. 57, 69-70; Seward to Campbel1, November 23, 1866, Campbel1 to Seward, December 1, 6, 1866, ibid., 40th Cong., lst Sess. , No. 30, 13-15, 17-18; Sheridan to Grant, November 8, 1866, January 12, 1867, Grant papers; Perkins, Monroe Doctrine, 504, 513.

$41_{\mathrm{Mr}}$. E. H. Saulnier to Seward, January 13, 1867, Mr. E. L. Plumb to Seward, March 7, 1867, Seward to Campbell, April 6, 1867, House Executive Documents, 40th Cong., lst Sess., No. 30, 39, 42, 58; Sheridan to Grant, April 18, 1867, Grant papers.

${ }^{42}$ Campbell to Seward, May 15, 28, 30, 1867, House Executive Documents, 40 th Cong., lst Sess., No. 30, 63, 69, 70; Sheridan to Grant, May 27, 1867, Grant papers.

43 Seward to Campbel1, June 1, 1867, House Executive Documents, 40 th Cong., lst Sess., No. 30, 70. The Brownsville Daily Ranchero, June 28, 29, 1867, sold out its issues announcing Maximilian's death on both days. There was much sympathy for Maximilian north of the border, but the liberals had suffered too much to do other than execute the emperor. 
country and its tragic termination in Mexico."44 Little Phil also immodestly asserted that the proximity of American troops to the Mexican border was the decisive factor in French withdrawal. ${ }^{4}$ Not all historians have agreed with his declaration. One of the most blistering attacks on the importance of the role played by the Army of Observation and seward's diplomacy, is that of C. A. Duniway. According to him, the American actions really had little influence on what Napoleon did in Mexico. Much more important, says Duniway, were the factors over which the United States had no control at all. Chief among these were the rise of Prussia, the inability of Maximilian to get along with his French military commanders, and the French internal political situation. ${ }^{46}$ Dexter Perkins, however, challenges Duniway's conclusions, pointing out that the German situation did not become a concern of Napoleon's until after the decision to withdraw from Mexico had been made. Perkins feels the decisive factor to have been American public opinion which demanded the triumph of the liberal government in Mexico. 47

While Perkins may be correct about the position of France vis a vis Bismarck's Prussia, in his emphasis on American public opinion

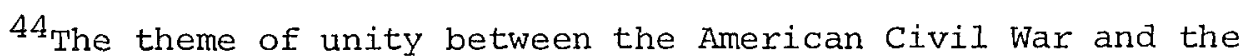
French intervention was constantly expressed, not only by Sheridan, but by Grant and Matias Romero. Sheridan to Rawlins, November 14, 1866, …‥, XLVIII, Pt. 1, 300; Sheridan to Grant, June 29, 1867, Grant papers; Sheridan, Personal Memoirs, II, 228; Miller, "Matias Romero," 231.

${ }^{45}$ Sheridan, Personal Memoirs, II, 227-28.

${ }^{46}$ C. A. Duniway, "Reasons for the Withdrawal of the French from Mexico," Annual Report of the American Historical Association, I (1902), $317,319, \overline{321,} 327-28$.

47 Perkins, Monroe Doctrine, 514-21.
} 
he appears to have slighted the real reason Napoleon withdrew his support from Maximilian, the internal political situation of France. By the mid-1860's Napoleon was on the defensive at home. Opposition politicians were challenging his control of the press, his control of the French assemblies, and most of all, the financial drain produced by Napoleons' long search for glory that spanned three great wars, 48 and the Mexican Adventure. Each episode was more costly to Napoleon in terms of French lives, the dwindling French treasury, and French public opinion. 49 Without support from home, 50 the French were helpless to do more than play for time, and hope Maximilian could establish himself firmly enough to withstand the Juarista opposition. The American stand was simply one more item on an already crowded list.

With the demise of the Mexican problem in the spring of 1867 , new domestic issues began to dominate Sheridan's thoughts as Congress drew up its final plans for the readmission of the southern states.

48 The Crimean war (1854-1856), the wars for Italian unification (1859-1861), and the Franco-Prussian War (1870-1871).

${ }^{49}$ See J. M. Thompson, Louis Napoleon and the Second Empire (New York, 1955), 220-21; Thomas w. Evans, The Second French Empire (New York, 1905), 140; Philip Guedalla, The Second Empire (New York, 1923, 2nd rev. ed.), 328-29; Archibald Forbes, The Life of Napoleon III (New York, 1897), 228; Walter Geer, Napoleon the Third: The Romance of an Emperor (New York, 1920), 242; G. P. Gooch, The Second Empire (London, 1960), 79-80; Albert Guerard, Napoleon III: A Great Life in Brief (New York, 1955), 162-63. Also of interest is Lynn M. Case (ed.), French Opinion on the United States and Mexico, 1860-1867 (New York, 1936), 402-36.

50 Albert Guerard, Napoleon III (Cambridge, Mass., 1943), 329-40, points out the half-hearted support of Maximilian when compared with the French effort in Morocco, where it took millions of francs, forty years of occupation, and a standing army of 60,000 to 85,000 men to subdue that part of North Africa alone. 


\section{SUBMISSTON BUT NOT ACCEPTANCE}

On August 11, 1865, the former postmaster general of the Confederacy, John $\mathrm{H}$. Reagan, wrote a letter in his cell at Fort Warren, Massachusetts. This lengthy "Fort Warren letter" was an appeal to his fellow Texans to "influence them to adopt a course which would save them from military government and from universal negro suffrage." Reagan began by stating that "our condition forces unwelcome thoughts and actions on us. . . " Therefore Texans had to adopt measures "which must be repugnant to your past experience and to your reason and your prejudices . . . " They were about to suffer "the necessity of political, social, and industrial reconstruction," he said. Because the state occupied "the condition of a conquered nation," all state government and state sovereignty were in abeyance until the United States chose to restore them. ${ }^{1}$

Reagan recommended that the state begin by recognizing the supreme authority of the Federal government and the abolition of slavery. He advised Texans to grant the former slaves equal civil rights and the franchise. At the same time, Reagan noted that the "evils" of an illiterate black vote could be mollified by property and educational requirements, provided that the tests were fairly administered to both blacks and whites. "If it be thought hard to

${ }^{1}$ John H. Reagan, Memoirs, With Special Reference to Secession and the Civil War (New York, 1906), 286-87. 
surrender so much," he stated, "it must be remembered that such is the fate of war . . ." Battle had solved the issues and no more discussion was needed. If Texas were wise and followed his recommended course of action, racial antagonism and political agitation would cease to interrupt the nation's prosperity. He realized "the painful struggles against education, and habit, and tradition, and prejudice, which such a course will require you to encounter," but he urged his countrymen "to exhibit this last crowning evidence. . . of your greatness and wisdom as a people."2

By the time Reagan had finished composing his "Fort Warren letter," nearly 10,000 former Confederates had already fled to Mexico rather than endure the "political, social, and industrial reconstruction" of the South. A large number of these refugees were Texans or Confederates stationed in Texas during the war. ${ }^{3}$ Fleeing bands of soldiers exacted tribute from the towns they passed through, looting and burning those villages that refused to contribute. Fearful of its fate, Rio Grande City raised $\$ 1,000$ for defense and employed a nearby cavalry company for protection. ${ }^{4}$ After the initial panic had passed, many who had hastily fled to Mexico wished to return home. Federal authorities allowed enlisted men to return provided they reported to

\section{Ibid., 287-92.}

${ }^{3}$ See William D. Wood, Reminiscences of Reconstruction in Texas and Reminiscences of Texas and Texans Fifty Years Ago (San Marcos, Texas, 1902), 5-6; Lawrence F. Hill, "The Confederate Exodus to Latin America," Southwestern Historical quarterly, XXXIX (1935-36), 100-34, 161-91, 309-26; W. C. Nunn, Escape from Reconstruction (Fort Worth, 1956).

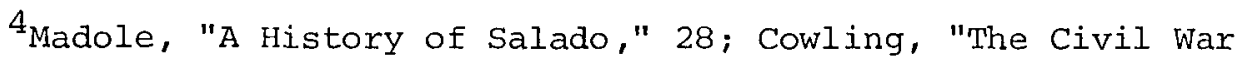
Trade of the Lower Rio Grande Valley," 143. 
the nearest Union army officer and signed a parole within thirty days of their arrival at their residences. Because of what sheridan termed "double dealing" after the surrender negotiations, commissioned officers and civilians charged with crimes were to be promptly arrested if they recrossed the Rio Grande. ${ }^{5}$ Most Texans, however, had never left the state because they had no money to finance the journey, knew of no place to go, and doubted Maximilian's ability to maintain his empire in Mexico. 6 "Your present duty is plain," General E. Kirby Smith had graciously reminded them before he fled to Mexico. "Return to your families. Resume the occupations of peace. Yield obedience to the laws. Labor to restore order. Strive both by counsel and example to give security to life and property."7

Preliminary reports to Andrew Johnson's provisional governor,

${ }^{5}$ Brig. Gen. James E. Slaughter to Brig. Gen. Fred steele, August 20, 1865, E. D. Townsend to Sheridan, October 14, 1865, Sheridan papers; GO 34, September 19, 1867, Printed Orders, Fifth Military District, R.G. 94, National Archives; Vera Lee Dugas, "A Social and Economic History of Texas in the Civil War and Reconstruction Periods" (Unpublished Ph.D. dissertation, University of Texas, Austin, 1963), 339-40.

${ }^{6}$ Belleville Countryman, July 1, 1865; John R. Baylor to Mary Maltby, January 11, 1866, Edward Clifton Wharton papers, Department of Archives and Manuscripts, IJouisiana State University. The Brownsville Daily Ranchero, April 10, 1867, called the immigration to Mexico "misguided." There was much suspicion that the French were aiding Confederate refugees escape to Mexico. See American Annual Cyclopaedia (1865), 319. For French interest in Texas during the Civil War, see Carland Elaine Crook, "Benjamin Theron and French Designs in Texas During the Civil War," Southwestern Historical Quarterly, LXVIII (1964-65), 432-54, and Charles W. Ramsdell, "The Last Hope of the Confederacy--John Tyler to the Governor and Authorities of Texas," The Quarterly of the Texas State Historical Association, XIV (1910-11), 129-45. others maintain that France kept the strictest neutrality during the war and after. See Milledge L. Bonham, Jr., "The French Counsels in the Confederate States," Studies in Southern History and Politics (New York, 1914), 104; Dabbs, The French Army in Mexico, 136, 142 .

${ }^{7}$ Army and Navy Journal, II (June 24, 1865), 689 . 
Andrew Jackson Hamilton, indicated that initially the defeated Texans did their best to follow Kirby Smith's advice. "I say nothing but the truth when I say as a people the bulk of our citizens exult in the overthrow of the secession oligarchy . . " wrote a Bonham Unionist. "In your task of organization," he continued, "our people will generally cooperate, on the basis laid down by the Federal administration." A committee of concerned citizens in Belton passed a series of resolutions which they sent to two state newspapers, General Granger, and the governor. The committee resolved that the war was at an end and "the questions which gave it origin are definitely set at rest." They further stated that they accepted the results of the war and pledged to be "good and faithful citizens of the United States." They also offered their aid in "the restoration of good order and the establishment of civil government." A Nacogdoches informant wrote to the governor that he believed a majority of the state had opposed secession in 1861, "and that that majority has since increased so as to umbrace nearly every man . . . " By early fall 1865 letters reported "things quieting down here" and the "people seemed resolved 'to be true and loyal.'" A Guadalupe County man wrote in October that "our once very rebel population" was no longer a threat to the nation. 8 Similar communications arrived in Army headquarters throughout the state. In the spring of 1866 the District of Texas ordered commanding officers to submit monthly reports on the condition of the people of the state. These reports were to include information about

${ }^{8}$ S. Hunt to A. J. Hamilton, July 6, 1865, Resolutions of Belton, July 20, 1865, Amos Clark to Hamilton, July 22, 1865, William Prusick to Hamilton, September 9, 1865, S. Wright to Hamilton, September 16 , October 6, 1865, all in Governor's papers (Hamilton). 
former Confederates, the treatment of northern men, refugees, and Negroes. Commanders were also asked to sample public opinion in their area and find the public's attitude toward the Army. ${ }^{9}$ First reports indicated there had been preliminary trouble at Yorktown. An officer and a German Unionist had been shot. Both men, however, were recovering rapidly and the area was reported to be "silent." Although citizens manifested no true Union sentiment, most were reported disposed to stay out of trouble. 10 In nearby Helena, the detachment commander found that the people disliked Unionists but he had received no complaints. Negroes were well treated and the area remained quiet. 11 Reports from other areas carried the same message. At Columbus, Captain George H. Merxill stated that most people treated refugees, freedmen, and soldiers well. He felt, however, that the Freedmen's Bureau and the military were necessary to restrain the less cautious persons in town. The officer in charge of Wharton, Texas, found identical conditions in his district. ${ }^{12}$ Along the coast the situation was particularly peaceful. Most citizens were friendly to soldiers and northerners although they remained "of the same unconquered

${ }^{9}$ Brig. Gen. Samuel D. Sturgis, CO, Sixth Cavalry and the Post of Austin, refused to submit such reports. He felt that the questions posed were too vague, and that he knew too few citizens for an accurate sampling of public opinion. See Sturgis to AAG, April 13, 1866, House Executive Documents, 40th Cong., 2nd Sess., No. 57, 123.

${ }^{10}$ Bvt. Brig. Gen. James Shaw, Jr. to AAAG, March 19, 1866, Capt. Collins Cheesebrough to AAAG, March 29, 1866, Maj. William Davis to AAAG, April 14, 1866, ibid., 95, 106-107.

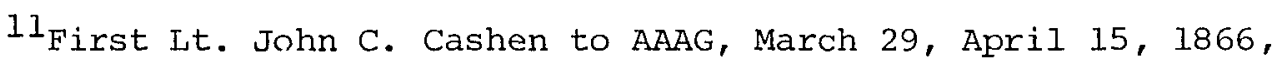
ibid. , 114.

12 Capt. G. H. Merrill to AAG, Maxch 25, April 10, 1866, First Lt. L. C. Manzer to AAG, March 25, April 10, 1866, ibid., 118-20. 
opinion." Negroes were treated differently by various people, but no pattern of racial intolerance was evident. In Brownsville, Major General George W. Getty reported everything to be satisfactory in all respects. 13

Even the volatile interior sections of east Texas, later a hotbed of racial violence, were quiet. Citizens were reported "legally loyal," and Negroes had experienced little adverse feeling from the white population. The presence of the Army was disliked, but there were few acts of violence perpetrated against blue-uniformed soldiers. What little trouble there was seemed to be caused by persons who had not fought in the war, usually loud-mouthed "grocery loungers." General Joseph A. Mower traveled to Jefferson and Marshall, where he found conditions so favorable that he recommended the withdrawal of their garrisons to Shreveport. Major T. H. Lathrop, the officer in charge of Houston, happily stated that the town experienced no incidents during the Fourth of July celebration in 1866. The citizens had willingly turned out in strength to raise United States flags on public buildings. ${ }^{14}$

These reports misjudged the true feelings of the state, just as Reagan found he had done. His letter had received the unqualified

13 Lt. Col. J. R. Lynch to AAAG, March 25, 1866, Capt. John Moran to $[$ AAAG], March 25, 1866, Capt. Thomas McCarty to AAAG, March 25, 1866, ibid., 103-104, 117, 125.

${ }^{14}$ See the reports of Lt. Col. R. Kennicott, Maxch 21, 1866, Maj. A. H. Longholy, Capt. Thomas Chapman, Lt. Col. H. B. Dox, Capt. H. Lossberg, First Lt. A. J. Norton, Capt. J. J. De Long, all dated March 25, 1866, Capt. Gallis Fairman, March 26, 1866, Capt. A. W. Evans, April 3, 1866, Capt. J. P. Gillespie, April 26, 1866, Bvt. Maj. Gen. J. A. Mower, May 21, 1866, Maj. T. H. Lathrop, July 5, 1866, ibid., 27-28, 98-101, 103, 109-10, 114-15, 117-18, 121 . 
praise of the Johnson administration, Republican congressmen and the Unionists of Texas. Governor Andrew Jackson Hamilton wrote the President and asked that he pardon Reagan and send him home. Elisha M. Pease, an influential Union man, echoed Hamilton's plea. ${ }^{15}$ But when Reagan returned to rexas, he found that "the people misunderstood the spirit and purpose of my letter and that they were not in condition to reason on the subject...." Reagan reluctantly concluded, "I had to abandon the idea of trying to induce them to make such concessions as it was certain would have saved them from both military government and universal negro suffrage." 16

Texans not only misunderstood Reagan's message, they also iniscalculated the feelings of the victorious North. Congress had never been too convinced by the outward manifestations of the state's devotion to the Union. In the spring of 1866 the Joint Committee on Reconstruction produced a series of witnesses whose testimony contradicted the assertions of loyalty which emitted from all of the southern states, including Texas. ${ }^{17}$ Thomas J. Mackey, a special.

15 Reagan, Memoirs, 227; Hamilton to Andrew Johnson, September 29, 1865, E. M. Pease to Johnson, September 28, 1865, Johnson papers.

${ }^{16}$ Reagan, Memoirs, 227-28; Ben Procter, Not Without Honor: The Life of John H. Reagan (Austin, 1962), viii, 181; Benjamin Harvey Good, "John Henninger Reagan" (Unpublished M.A. thesis, University of Texas, Austin, 1932), 294.

${ }^{17}$ Some of the congressional testimony was in the same vein as the letters and reports quoted above. See the statements of Caleb G. Forshey, Benjamin C. Truman, and Stephen Powers, in "Report of the Joint Committee on Reconstruction," House Reports, 39th Cong.., 1st Sess., No. 30, Pt. IV, 129-32, 136-40, 145-50. Truman's comments are amplified in his comprehensive report. See Senate Executive Documents, 39th Cong., lst Sess., ivo. 43. 
provost marshal in northern Texas, declared that "the masses of the people, never having felt the power of the government, scorn its clemency." A lieutenant stationed at Corpus Christi claimed that the people were becoming more and more insolent each day. He believed the solution rested in the application of more force. "Knocking down a rebel officer in the presence of his friends," concluded the lieutenant, "is very likely to exert a salutary influence for some time." General Custer found that Texans accepted the loss of the war, but they were "not at all friendly." He blamed the weak, vacillating Reconstruction policy of President Johnson for the increased defiance he saw in the state. Custer and other witnesses feared that if Texas were left unsupervised by the Federal government, the Negro would soon be placed in a form of pseudoslavery. ${ }^{18}$

Other testimony before the committee was of the same nature. Brigadier General William E. Strong, an inspector for the Freedmen's Bureau, was shocked to find slavery existing in eastern Texas in the fall of 1865, and he believed the institution was still extant in February 1866 as he submitted his report on conditions west of the Sabine River. Most of the witnesses agreed that the only solution was to garrison Texas with Union soldiers. One officer recommended a five-year occupation, but Custer felt that "our national safety in times to come" depended upon an indefinite term of occupation in the southern states, "until satisfied that they may, without detriment,

18 For the items mentioned in the text, see House Reports, 39 th Cong., lst Sess., No. 30, Pt. IV, 44, 72, 73, 76. Mackey was wanted in Texas for murder on a warrant issued by Governor Hamilton. See Haruiton to the Governor of Louisiana, April 2, 1866, Executive Correspondence, Axchives, Texas State Library, Austin. 
be intrusted [sic] with their former rights and privileges." Custer, as yet, had failed to see the Texans "manifest a penitent spirit for the great crime committed against the nation" or give any guarantee of better conduct in the future. Another general officer agreed. Major General Christopher C. Andrews believed Texans should be "made to understand that the privilege of franchise which they had forfeited was a high trust, to be extended to those only who should become heartily and unconditionally loyal." In the words of Texas refugee John T. Allen, "the last and only hope of loyal men is in the republican [sic] party in Congress." 19

One of the major problems that troubled not only Congress, but Texas Loyalists, was the political activity of former Confederate officials. "The people of the state. . have lost all sense of duty," complained one Unionist, "and are still determined to 'rule or ruin'. . . Such men care no more about an oath than a hog does about Sunday." Another informant wrote to Governor Hamilton that Colonel. Ashbel Smith, the envoy who tried to gain milder surrender terms for the state several months earlier, had been addressing political meetings in Houston. Smith was attempting to organize a political coalition composed of prominent Rebels. From Galveston came a letter testifying that "the hottest rebels.. . are getting all the Government Offices." Similar letters from all over the state arrived on the governor's desk, the writers asking to be relieved from the

19 House Reports, 39th Cong., Ist Sess., No. 30, Pt. IV, 36, $41,44,4 \overline{8,75}, \overline{78,92}, 125$. 
political control of the "disloyal element." 20

In addition to "disloyal" political activity, the Unionists

and the Army reported numerous attempts on the lives of men who professed their loyalty to the victorious Federal government. When General Custer sent Captain Jacob Greene into northeastern Texas to sample public sentiment there, Greene reported that the former Confederates were submitting to the results of the war with "an intense hatred." Greene found evidence that a large minority of the population was eagerly awaiting the day when they could pay the Yankees back and run the freedmen out of the state. Many letters and military reports mentioned the murder of Unionists, numerous cases of "high felony," continued slavery, the formation of a "Knights of the Golden Circle or something" to overthrow the Hamilton regime, and hostile feeling to troops and northerners in general. Loyalists disliked the Reconstruction policy of President Johnson; they blamed its mildness and forgiveness for making "the leading barbarians of the rebellion only more impertinent." A Corpus Christi man said that "nothing but severe handling will bring such fellows to their sences," while another concerned citizen recommended hanging the "leaders of the Rebellions."2l

20 John A. Wright to Hamilton, June 21, 1865, John Now [?] to Hamilton, July 18, 1865, J. M. MCAlpine to Hamilton, August --, 1865, Thomas F. Hudson to Hamilton, September 8, 1865, Petition of Citizens of Sabine County, October --, 1865, Petition of Citizens of Grayson County, November 10, 1865, Governor's papers (Hamilton).

${ }^{21}$ All spelling in the original. Merington, The Custer story, 176; J. J. Thornton to Hamilton, July --, 1865, A. A. Deavalon to Hamilton, July 10, 1865, w. Longworth to Hamilton, October 10, 1865, Governor's papers (Hamilton); Capt. A. W. Evans to AAG, April 18, 1866, House Executive Documents, 40th Cong., 2nd Sess., No. 57, 115-16. For other letters of the same content, see Capt. T. S. Post to Hamilton, August 30, 1865, John C. Weaver to Hamilton, January 26, 1866, The 
Unionist fears were evident in the innumerable requests for soldiers to be stationed throughout Texas. In Angelina County, thirtysix persons signed a petition asking for a garrison "to aid in the restoration of law and order, or afford protection until such can be done." The petition reported that "the Rebels of said county" were murdering, stealing, and robbing the inhabitants. Bandits or Confederate units that refused to surrender also plagued other areas of the state. A Bell County petition asserted that twenty known law violators were at large. The outlaws' leader boasted he had one hundred men who would protect him, and no one dared arrest him or his men. At Castorville the local sheriff was shot down and no one would hazard taking his place. The county judge requested a squad of twenty soldiers to uphold the law. 22

Other requests for troops were of a more political nature. Loyal Texans in Caldwell County protested gatherings of armed men that jostled and cursed Unionists in the Lockhart town square. They charged that their officials were incompetent and that slavery was

Children of Moritz Riedel to Hamilton, March 9, 1866, Governor's papers (Hamilton). See also, Lt. Col. Thomas M. Browne to Sturgis, February 12, 1866, and the reports of Maj. W. T. Baker, March 25, 1866, Lt. Col. E. H. Powell, March 27, 1866, Capt. G. Harazthy, March 28, 1866, Lt. Col. O. E. Pratt, March 28, April 12, 1866, Capt. S. P. Gillespie, April 11, 1866, Judge H. Christian, and others, April 12, 1866, Capt. Ira W. Clafin, April 17, 1866, Capt. George H. Henderson, April 28, 1866, Bvt. Lt. Col. William S. Abbott, October 20, 1866, all in House Executive Documents, 40th Cong., 2nd Sess., No. 57, 22-23, $32-33, \overline{100,106,111-12,116-17,} 121-25$.

${ }^{22}$ N. U. Gunn and 35 others to Hamilton, July --, 1865, H. Christian and 3 others to Hamilton, October 9, 1865, James Herrington and 20 others to Hamilton, n.d., Sheriff W. B. Pace to Hamilton, March 20, 1866, Judge G. H. Noonan to Hamilton, March 22, 1866, all in Governor's papers (Hamilton). 
still a common practice. They felt Federal soldiers were the only solution. C. B. Binkley reported to the post commander at Austin that troops should be sent north to Sherman. The townspeople were outspokenly disloyal and refused to submit to United States law, outlaws abounded in the area, and the Union men who had once before written asking for Federal aid were now marked for vengeance. Flake's Bulletin of Galveston believed it would be the height of folly to set up the new state government without the Army's assistance. It reprinted an article from a New Orleans newspaper which concluded that "no citizen of that state can reasonably object to the introduction of troops there." The Dallas Herald was not so enthusiastic in announcing the expected arrival of Union troops to render assistance "in closing up government business... . So far as this county is concerned, we believe that none will be required."23

Governor Hamilton, however, disagreed with the Herald's editor. The governor believed that "the spirit of rebellion is rampant in this state, and while there is no intention to organize armed resistance to the United States government, there is every disposition to browbeat and maltreat its friends the Unionists." Hamilton worried about the increasing violence. "Human life in Texas," he admitted, "is not worth as much . . . as that of domestic cattle." General Sheridan concurred with the Governor and informed him that, in his opinion, more soldiers were needed in the state. Because of the

${ }^{23}$ See, Petition of Citizens of Caldwell County, January 24 , 1866, C. B. Binkley and 2 others to Sturgis, February 12, 1866, in ibid.; Flake's Daily Bulletin (Galveston), July 8, 1865; Dallas Herald, October 14, $186 \overline{5 .}$ 
demobilization process, Texas was losing troops and there were none to spare from other departments. 24

The lack of troops and increasing intimidation of Union men merely made Hamilton's difficult responsibility of establishing a loyal government just that much harder. Usually called "A. J." or "Colossal Jack," Hamilton migrated to Texas from his native Alabama in 1847. Eventually arriving at Austin, he practiced law and entered politics, serving as state attorney general and as a state legislator. A Democrat, Colossal Jack broke with the party's southern wing in the late 1850's and successfully campaigned on Sam Houston's ticket for a seat in Congress. After supporting Stephen A. Douglas in the 1860 presidential race, Hamilton returned to l'exas shortly after its secession. In 1862, his outspoken Unionism forced him to flee to Mexico. Escaping Texas successfully, he traveled to New Orleans. While living there, President Lincoln tendered him a commission as brigadier general of volunteers. Shortly thereafter Lincoln also made him the military governor of Texas. The failure of the Red River campaign in 1864 prevented Hamilton from being more than an exiled official with no real authority. 25

24 The shortage of Federal soldiers can be seen in Sheridan to Hamilton, February 5, 1866, Sturgis to Hamilton, March 19, 1866, Governor's papers (Hamilton); Hamilton to Sheridan, February 26, 1866, House Executive Documents, 40th Cong., 2nd Sess., No. 57, 26; Hamilton to Andrew Johnson, March 28, 1866, Johnson papers.

25 John L. Wallex, Colossal Hamilton of Texas: A Biography of Andrew Jackson Hamilton (E1. Paso, 1968), ix, 3-55; John Robert Adkins, "The Public Career of A. J. Hamilton" (Unpublished M. A. thesis, University of Texas, Austin, 1947), 146; Homer S. Thrall, A Pictorial History of Texas from the Earliest Visits of European Adventurers to A.D. 1879 (St. Louis, 1879 ), 549-50. 
In the spring of 1865 President Johnson appointed Hamilton provisional governor with instructions to reestablish civil government, administer loyalty oaths and pardons, and convene a constitutional convention to adjust the state document to coincide with the results of the war. Texans received the news of Hamilton's appointment with some apprehension. They feared he would be vindictive about the hostility which had forced him to leave the state. Hamilton, however, quickly proved himself to be a moderate, conciliatory person who would administer Texas with a firm, just hand. 26

The new provisional governor disembarked at Galveston on July 22 and arrived in Austin a week later. All along his route of travel, Unionists turned out to meet and cheer him along. Hamilton wrote the President that not only were Union men happy about his arrival, but the "poor men" were also glad and they were taking the oath of amnesty freely. Colossal Jack mentioned that he was being deluged with requests for pardon from former Confederate officials and rich planters, but he cautioned the President against enfranchising these proscribed classes too soon. The governor feared their pardon would only return these men to power and hamper Reconstruction. A. J. bemoaned the fact that the government had not confiscated the property of a few leading Rebels. It would have had a good effect on the South, he said, but the proper time had already passed. 27

${ }^{26} \mathrm{Maj}$. Gen. C. C. Andrews to Johnson, July 28, 1865, Johnson papers; Waller, Colossal Hamilton, 58; Ramsdell, Reconstruction in Texas, 55-56; Wortham, A History of Texas, V, 2; Wallace, Texas in Turmoil, 163.

27 Hamilton to Johnson, July 24, 1865, Andrew Jackson Hamilton papers, Archives, University of Texas; Hamilton to Johnson, August 30, 
Hamilton's first task as governor was' to organize a provisional government to handle state affairs until a new administration could be elected under a revised constitution. He believed it was best to move slowly in the reorganization because of the lack of civil control, the vast size of Texas, and the impracticality of putting troops everywhere. Time was needed to find loyal men to whom the machinery of state government could be entrusted. Time was also necessary to organize the Unionists into a political party with enough power to win the postwar election. 28

The Loyalists suggested organizing their backers through political patronage and requests for jobs poured in by the hundreds. ${ }^{29}$ It was here that Hamilton's policy first caused a great deal of controversy. Contrary to charges that he dismissed former Confederates Exom offices, A. J. was so judicious in his appointments that many Loyalists feared he would turn the state over to unreconstructed Rebels. The governor denied charges that he appointed unrepentant Confederates, although he admitted that he had been fooled by some of his choices. But the simple fact was that there were not enough Unionists willing and available to fill the nearly three thousand

1865, Johnson papers. See also, Waller, Colossal Hamilton, 61; Ramsdell, Reconstruction in Texas, 57-58; Bancroft, A History of the North Mexican States and Texas, II, 478.

${ }^{28}$ Hamilton to Johnson, August 30, 1865, James H. Bell and others to Johnson, August 30, 1865, Johnson papers.

${ }^{29}$ For examples of requests for office and assertions of loyalty, see Charles A. Page to Hamilton, July --, 1865, A. H. Willie to Hamilton, August 4, 1865, Dr. Thomas Hertzberg to Hamilton, June 27, 1865, Governor's papers (Hamilton). 
appointments made. ${ }^{30}$ Hamilton, by necessity, had to use repentant Confederates, and he merely followed the Army's lead in this matter. ${ }^{31}$ In addition to appointing local civil authorities, Governor Hamilton was expected to supervise the adninistration of the loyalty oath and approve all applications for presidential amnesty. At first, the Army was in charge of taking the parole of former Rebel soldiers, but by August 1865, this function had been turned over to the provisional government. Hamilton delegated the power of administering the oath of allegiance in each county to a three-man board which consisted of the local chief justice, clerk of the county court, and clerk of the district court. 32

After the oath had been administered, the same three-man board registered all qualified persons to vote. President Johnson was disappointed that Texas was still registering voters while the rest of the South had already revised their constitutions and elected new state

${ }^{30}$ See E. A. Stevens to Hamilton, August 1, 1865, O. H. P. Garrett to Hamilton, August 7, 1865, ibid.; Hamilton to Johnson, September 23, 1865, Johnson papers. Hamilton's appointments may be found in the Election Registers, Nos. 261 and 262, Secretary of State's papers, Archives, Texas State Library. See also, Waller, Colossal Hamilton, 64-67, 71-72; Ramsdell, Reconstruction in Texas, 61; BanCroft, History of the North Mexican States and Texas, II, 479; W. C. Nunn, Texas Under the Carpetbaggers (Austin, 1962), 3; Reese, "A History of Hill County," 134 .

310. H. Garrett to Hamilton, August 7, 1865, GO 9, August 4, 1865, Post of Galveston, Governor's papers (Hamilton); Flake's TriWeekly Bulletin, June 17, 1865.

32 Proclamation of August 19, 1865, Executive Correspondence. See also, William B. Moore to Hamilton, August 1, 1865, C. W. Buckley to Hamilton, August 22, 1865, H. W. Kyser to Hamilton, October 21, 1865, Governor's papers (Hamilton); Waller, Colossal Hamilton, 79. 
officials. Hamilton apologized to the Chief Executive and stated that several things had slowed the process in Texas. The state's citizens still suffered greatly from their wounded pride at the downfall of the Confederacy. There was also much vindictiveness in Texas and an unwillingness to acknowledge the errors of secession. Most of all, Hamilton decried the absence of the Army from many sections of the state. Without Army control, these areas refused to concede the authority of the United states. Hamilton feared that any large population outside the military's control would only act to sabotage and prolong Reconstruction. Nevertheless, Colossal Jack ordered the convention election to be held January 8,1866 so the members could assemble on February $7 .{ }^{33}$

When the convention convened, it quickly became apparent that the Loyalists were in a minority. While the majority was not Secessionist, it was definitely conservative and composed of men who had followed Texas into war, regardless of how they felt about the legality of secession. This attitude was typified by James W. Throckmorton, the president of the convention. Throckmorton had been a Unionist in 1861. When Texas seceded, however, he accepted a brigadier generalship and helped organize the state's frontier defense. ${ }^{34}$ The politically attuned Hamilton quickly grasped the convention's mood. Several months earlier he had declared, "I am willing to take my chances with the Blacks" on social equality. He also asserted that "no fowler slander was ever uitered than that this is and was intended to be 'a White

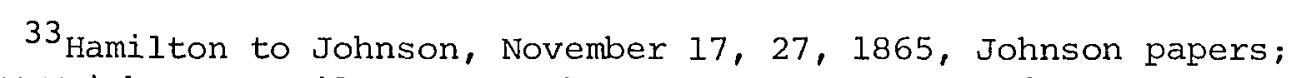
D. F. McKnight to Hamilton, December 29, 1865, Governor's papers (Hamilton); Ramsdell, Reconstruction in Texas, 61.

${ }^{34}$ Ramsdell, Reconstruction in Texas, 89. 
mans Govt.'" Instead, Hamilton had said, "It is and was intended to be a free mans Govt. . . ." Now he stood in front of the state convention and thanked God "that this is a white man's Government, and I humbly trust that the time will never come when it shall cease to be so." Then out of the other side of his mouth, the soft-stepping state executive asserted that he felt it would be wise to grant the Negro equal civil and political rights, in principle anyway. 35

After Hamilton's speech, the convention slowly got down to work. Following the procedure prescribed in President Johnson's Reconstruction program, 36 the sovereign body took up the problems of emancipation, the Confederate debt, and repudiation of secession. It recognized the freedom of the black race as a fact established by the force of arms. Since its revival was prohibited by the Thirteenth Amendment, the convention declared the "peculiar institution" to be at an end, but refused to ratify the amendment. It also granted the Negroes the basic rights of person and property, the right to sue and be sued, to be punished in the same manner as whites, and to testify in court in all cases concerning their race. The convention left it to the state legislature to grant Negroes the right to testify in all other cases. 37 Texans not only repudiated the war debt, they nullified the entire

${ }^{35}$ Spelling in the original. Waller, Colossal Hamilton, 62 , 88-89; undated speech, 1865, Hamilton papers; speech to the State Convention, February 10, 1866, in Journal of the State Convention Assem-

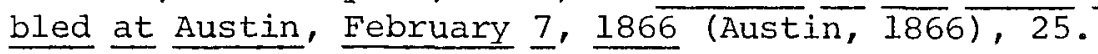

${ }^{36}$ James D. Richardson (comp.), A Compilation of the Messages and Papers of the Presidents, 1789-1897 (10 vols., Washington, 1897 ), VI, $321-23$.

37 The actual debates may be followed in Journal of the state Convention - - 1866. For a good synopsis of the proceedings, see Ramsdel1, Reconstruction in Texas, 99-101. 
state debt contracted between January 28,1861 and August 5, 1865. 38

Having disposed of slavery and the debt, the convention turned to the secession ordinance. It was here that the longest, most volatile debate occurred. The problem was whether to declare the secession ordinance void because of the results of the war or whether it was null and void $a b$ initio, that is, from the date of its inception. The staunch Unionists favored the latter position, but failed to convince the majority who voted for the milder provision. Hamilton and the Army had already recognized and followed all Texas laws not in conflict with the laws of the nation; the convention decided to do the same. 39

The convention also modified the Constitution of 1845 in other respects besides those required by President Johnson. The terms of state offices were increased from two to four years, and officeholders were given a raise in salary. The increased terms of office coupled with the denial of the right to vote to the Negro were obvious political moves by the conservatives to insure Democratic control of the state just as before the war. 40

In his Fort Warren letter, John Reagan had recommended that his fellow Texans demonstrate "greatness and wisdom as a people," realize

${ }^{38}$ Ramsdell, Reconstruction in Texas, 102 .

${ }^{39}$ Ibid., 94-96, 103-104. The ab initio issue is also discussed in Bancroft, History of the North Mexican States and Texas, II, 495; Wortham, A History of Texas, V, 52-53; and Wallace, Texas in Turmoil, 173. See also, Hamilton to Johnson, March 17, 1866, Johnson papers.

40 Ramsdel1, Reconstruction in Texas, 106 , plays down the political motives for the constitutional changes, but Frances Dora Ryan, "The Election Laws of T'exas, 1827-1875" (Unpublished M.A. thesis, University of Texas, Austin, 1922), 49, fully realizes the implications of the amendments. 
the realities of defeat, and admit the Negro to political and civil rights. By early 1866, however, Texans more and more expressed feelings similar to those of Thomas Affleck, a Brenham planter and an uncompromising, never-to-be-reconstructed Confederate. Affleck evidenced a deep burning hatred of the Yankees who had stripped him of the work of a lifetime and freed his slaves, and he vowed he would never hug the conqueror. He had taken the loyalty oath and he would support the Federal government. But the situation, he wrote the editor of the Houston Telegraph, was one "to be submitted to, but not accepted, as you flippantly insist... ." If Texans were willing to ostracize the likes of John Reagan, they would take even stronger measures to insure the restoration of the old political order. 41

4.1 Thomas Affleck to E. H. Cushing, July 24, 1865, Thomas Affleck papers. 


\section{NOT STRONG ENOUGH TO CARRY AN ELECTION}

On the last day of July 1865 editor Frederick Flake wrote a worried note to Provisional Governor Hamilton. The Federal soldiers had occupied Texas for a month and a half, the provisional government had recently been established, and all seemed well. But the loyal men of Galveston were troubled. Flake, editor of the influential Unionist sheet, Flake's Bulletin, expressed their fears: "I have, as directed by you, consulted with most of the Union men in this county. All agree that we are not strong enough to carry an election and that it is desirable you should appoint all officers . . . "l The Loyalists, however, could not rely on appointments forever; sooner or later, they would have to face an election.

Establishing a loyal civil government in Texas, one of the prime goals of Military Reconstruction, was an extremely involved process which lasted nearly five years. After the adjournment of the convention, the Unionists and the Conservatives quickly plunged into the campaign preceding the June 4 elections. Because there was less than two months in which to canvass the state, both factions did without nominating conventions and resorted to the old caucus method. The Conservatives put forth a ticket headed by James $W$. Throckmorton, the convention president. The Unionists turned to Hamilton who was forced

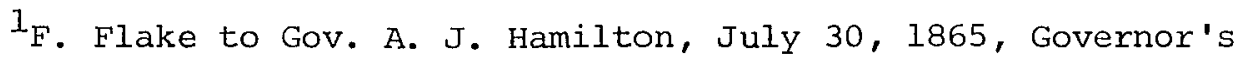
papers (Hamilton). 
to decline because of personal monetary problems. They then nominated Elisha M. Pease, a Connecticut man who had lived in Texas since the first days of the Republic. A lawyer by training, he had handled numerous state clerical positions and served as Comptroller of Public Accounts. Prior to the war, he was a state legislator and held the governorship for two terms. Refusing to support the Confederacy, Pease had sat out the war in Austin. ${ }^{2}$

Pease's inaction during the war, and the very name of his Union party, doomed him and his party to failure and he knew it. There was but one question in the June election, loyalty to the South. Regardless of what a candidate believed about secession, he must have supported his state and section. Throckmorton's backers wisely adopted the Conservative Union party label, indicating that they accepted the results of the war but without enthusiasm. In this manner, they also tempered the Loyalists' charge that they refused to abide by the war's outcome. 3

${ }^{2}$ Ramsdel1, Reconstruction in Texas, 106-108; Thrall, A Pictorial History of Texas, 598; Benjamin Hillon Miller, "Elisha Marshäl Pease: A Biography" (Unpublished M.A. thesis, University of Texas, Austin, 1927), 121-22. For letters urging Pease's candidacy, see A. B. Burleson to Pease, April 8, 1866, Thomas H. Stribling to Pease, April 9, 1866, James R. Burnett and 15 others to Pease, May 16, 1866, H. G. McDaniel to Pease, May 17, 1866, all in R. Niles Graham-Elisha Marshall Pease Collection, Archives, Austin Public Library, hereinafter cited as Pease papers.

${ }^{3}$ Pease to Carrie [his daughter], May 8, 18, 1866, Pease papers. The terms "Radicals" and "Conservatives" as used by Texas historians for this period are misleading. See, e.g., Ramsdell, Reconstruction in Texas, 106, and Wallace, Texas in Turmoil, 179-80. The election in $\overline{186} \overline{\mathrm{had}}$ one issue--Unionism. The Republican party was not organized until over a year later. Even then, there was no real "Radical" party in Texas until the Republicans split over the issues of the 1868-1869 convention in the summer of 1869. "Radicals" were always present, but to label the opposition party of the Democrats as such before 1869 is 
The Unionists suffered not only from a poor issue, but also because Pease was an extremely despondent candidate. He wrote his daughter shortly after he was nominated that he consented to run "against my own wishes as I know it is against the wishes of Mama . . ." A month later he was still saying that he did not "feel any personal interest in being elected" and that he ran only because he "would not have the Union men of Texas say that they could have succeeded if I had [but] become a candidate."4 Ignoring advice to "direct the campaign as much as possible of a partizan character," Pease plodded along to defeat. Conservative newspapers refused to attack the mild Pease and, instead, lambasted his Unionist supporters for their cowardice during the war. 5

The party's problem, however, ran deeper than its name or the campaign style of its candidate. The Union party simply lacked organization at the grass roots level. Edmund J. Davis, an early Pease supporter, said that a home guard was needed to protect Union voters fxom intimidation and to organize candidates and votes. Most of all, a broader base of power was needed. Union men made up less than onethird of the white population of the state. Davis recommended that the party change its name to "Republican," and call a state convention of all males twenty-one years of age or over. "By all means let us

to inaccurately describe the majority of its supporters. Men like Hamilton and Pease were never really in the "Radical" camp.

${ }^{4}$ Pease to Carrie, April 9, May 8, 1866, Pease papers.

${ }^{5}$ E. H. Cushing to Pease, March 24, 1866, Alexander Rossy to Pease, May 8, 1866, ibid. The bitter canvass spoken of by Ramsdell, Reconstruction in Texas, 109, was really much milder. See Miller, "Pease," 123. 
save ourselves, if in our power, from Rebel rule," he concluded. 6

Rebel rule, however, became an established fact on June 4, 1866 , when the Conservatives soundly trounced the Unionists throughout Texas. Throckmorton garnered 49,000 votes while Pease pulled slightly over 12,000. The same election approved the amended state constitution, although by only 5,000 votes. ${ }^{7}$ President Johnson now had to accept a government composed of men not of his own choosing or deny the practicality and validity of his Reconstruction program. Rather than admit defeat, the President made the best of a poor situation and backed the results of the election. ${ }^{8}$ The election had forced the President and the Conservatives into an unforeseen alliance. ${ }^{9}$ Johnson's former supporters in Texas, Hamilton, Pease, and the Unionists, now had to find a new sponsor or become politically impotent. The only source open to them was the National Republican party. Providentially, Congress was also at odds with the President over his vetoes of the Freedmen's Bureau and Civil Rights bills. In the summer and fall of 1866 the division was completed when the President made his disastrous "Swing Around the Circle" speaking tour of the North attacking congressional

${ }^{6}$ E. J. Davis to Pease, July 14, 1866, Pease papers. Emphasis in the original.

${ }^{7}$ Ramsde11, Reconstruction in Texas, 111-12; Brown, History of Texas, II, 444-46.

${ }^{8}$ Kenneth Stampp, The Era of Reconstruction (New York, 1965), 71-73. For the turnover of power, see the Circular of James H. Bell, Texas Secretary of State, August 13, 1866, Executive Correspondence.

9 Ramsde11, Reconstruction in Texas, 111 , errs when he calls the Johnson-Throckmorton alliance "natural." Johnson was maneuvered into the alliance by forces he could not control. 
leaders by name. 10

On August 13, 1866, Throckmorton was inaugurated as governor. A Tennessean by birth, the new state executive had come to Texas in 1841 . He was elected to the state legislature several times during the $1850^{\prime} \mathrm{s}$, and was a member of the secession convention where he had the distinction of being one of eight to vote against secession. He served in the Confederate army during the war and as a state senator. When Texas surrendered in 1865, Throckmorton was in Indian Territory treating with the Comanche. His overwhelming victory indicated that Texans believed endorsing his type of war-time Unionism w ; as far as they could go in placing a "loyal" man in office. 11

Shortly after Throckmorton assumed office, President Johnson issued his proclamation declaring the rebellion in Texas to be ended. ${ }^{12}$ Throckmorton and the Eleventh Legislature thought that the proclamation reestablished the supremacy of the civil government over any military authority, and they acted to secure this power. In his message to the legislature, the governor recommended that laws be passed safeguarding Negro rights, that Federal txoops be petitioned to withdraw from the interior, and that the frontier be more fully pro-

${ }^{10}$ The split between Johnson and Congress is detailed in Eric L. McKitrick, Andrew Johnson and Reconstruction (Chicago, 1960).

11 Thral1, Pictorial History, 625-26. Claude Elliott, Leathercoat: The Life History of a Texas Patriot (San Antonio, 1938), is the standard work on Throckmorton. See also, Ruby Crawford Holbert, "The Public Career of James Webb Throckmorton, 1851-1867" (Unpublished M.A. thesis, University of Texas, Austin, 1932).

12 Richardson (comp.), A Compilation of the Messages and Papers of the presidents, VI, 438 . 
tected. Throckmorton also suggested that the part of Texas extending north of the Red River might be sold to the United States for Indian reservations. All in all, the governor's address was very moderate. ${ }^{13}$ Throckmorton, however, reckoned without the legislature. The governor was a Conservative of the Union variety. He understood the responsibilities and requirements expected of his state in Reconstruction, particularly in giving equal legal rights to the black population. Men like Throckmorton had controlled the state convention where their prominent role had helped elect some of them to various local and state offices. Most of the Conservative Unionists chose not to run for public office, which allowed the legislature to be dominated by secessionists who had been on the "right" side in the war. Although Throckmorton was willing to compromise with the national administration, these men were out to obstruct Reconstruction as much as possible. ${ }^{14}$ In the legislature the Secessionists began their quarrel with the Conservative Unionists over the election of the United States senators. According to prior agreement, the legislature was to choose one senator from the western part of the state and one from the eastern part. The Conservative Unionists expected at least one of the senators to be of their political persuasion, and they supported John Hancock and Benjamin H. Epperson, both of whom had opposed leaving the Union. The Secessionists, however, banded together and elected David G. Burnet

13 Elliott, Leathercoat, 137-39, 166-67; Holbert, "The Public Career of . . Throckmorton," 82-92; Wallace, Texas in Turmoil, 186-89; Wortham, A History of Texas, V, 49; Bancroft, A History of the North Mexican States and Texas, II, 484, 490. 296.

$$
\text { 14 Ramsde11, Reconstruction in Texas, 114; Elliott, Leathercoat, }
$$


and Oran M. Roberts, both outspoken Rebels. Then the legislature proceeded to pass the infamous "Black Codes" which denied the Negroes full legal rights. At the governor's suggestion, the legislators authorized the enlistment of a state army to help defend the frontier. ${ }^{15}$ Although Throckmorton undoubtedly agreed with the legislative act regarding the frontier, he did not expect nor recommend the Black Codes or the election of Rebel senators. The governor now found himself in the same predicament President Johnson had experienced in June; he had headed the ticket that helped elect the lagislators and he could not now repudiate his own state government. To do so would be an admission that lexas could no longer adequately govern itself, and Throckmorton was too much of a democrat to deny that the people were the wisest rulers of the state. Like any good politician, the governor chose to lead his people and stay in power. Accordingly he moved over to the secessionist side. 16

Throckmorton's shift brought angry denunciations from both the military and the Unionists. Sheridan disgustedly referred to the "anomalous, singular and unsatisfactory" condition of Texas civil affairs. The state executive had for his standard "Pride in Rebellion; that it was a righteous but lost cause, being overpowered by the Federal forces," remarked Sheridan. He was doing his best to support the elected government "but it has been embarrassing in the extreme," said

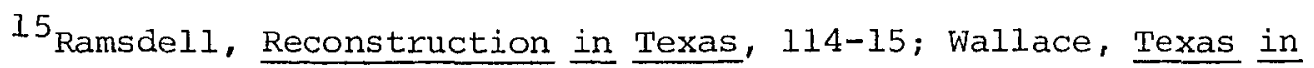
Turmoil, 184-85; Wortham, A History of Texas, V, 16; Bancroft, History of the North Mexican States and Texas, II, 485-90.

16 For the governor's reluctance to relinquish his office and leadership see Elliott, Leathercoat, 175-76. 
the general. Sheridan particularly marvelled that while Hamilton had constantly demanded more troops, Throckmorton seemed to deny their need at all. 17

The Unionists were equally dismayed about "Rebel rule." A San Antonio man reported that the influence of Throckmorton was so strong that even the local Federal garrison was on his side. Another Union man claimed that Army supply contracts were let mostly to ex-Rebels. Something obviously had to be done. "Henceforth we must rely upon the great Union party of the Country now represented by an overwhelming majority in Congress," said Hamilton. After his defeat, Elisha M. Pease had left for a Connecticut vacation and now he was utilized to explain the Texas situation to Congress. UnIess Congress acted to save the Unionists, the loyal voice in Texas would die out. The officeholding clause of the Fourteenth Amendment was deemed insufficient to insure Union control in Texas. Loyalists had even feared that Throckmorton's legislature would approve the amendment to stay in power. More stringent measures to disfranchise all former Confederates were needed, wrote Judge F. H. Duval to Pease. Duval wanted all voters to be required to take an oath that they had never voted for secession. ${ }^{18}$

The Union men need not have feared the Texas legislature's approving the Fourteenth Amendment. Already confident that they had won final control of the state, the legislature rejected the amendment

${ }^{17}$ Sheridan to Rawlins, November 14, 1866, Grant papers; Sheridan, Personal Memoirs, II, 232-33; Holbert, "The Public Career of . . . Throckmorton," 105.

18 J. L. Haynes to Pease, December 30, 1866, L. B. Camp to Pease, January 3, 1867, F. H. Duval to Pease, October 18, 1866, January 25, 1867, Pease papers; Speech of July 2, 1866, Morgan Hamilton to A. J. Hamilton, January 8, 1867, A. J. Hamilton papers; Miller, "Pease," 124 . 
and began to counterattack those "experimenting, humbuging, rascally, fanatical hounds of hell," as Throckmorton characterized the Loyalists. The Conservative regime utilized the state's newspapers as its sounding board. Pease's Washington activities were given a special blast by the Galveston Tri-Weekly News. "Too cowardly to rob, and too mean to beg," Pease had compromised and become "the swift and paid witness of those who are willing to pay for a lie," accused the News. Governor Throckmorton also cautioned President Johnson against believing men like Pease, whose only purpose was to falsely discredit the elected state government. 19

The only cheering news received by Texas Unionists during the winter of 1866-1867 was the hardening attitude of Army officers toward Throckmorton's government. Rumors spread that at last Congress would act to aid the Loyalists "if need be, by real military occupation," as one happy Union man put it. In January 1867 there was even talk among the loyal men as to whom they should recommend as the new military governor when the time came. 20

At the same time that Texans had been coping with the problems of choosing a new government, the Army was solving a few difficulties of its own. For reasons of geography, General Sheridan really had little to do with Texas Reconstruction. His headquarters were in New

${ }^{19}$ Throckmorton to B. H. Epperson, January 21, 1866, Benjamin H. Epperson papers, Archives, University of Texas; Throckmorton to Johnson, July 24, 1866, Johnson papers; J. L. Haynes to Pease, October 1, 1866, and clipping from Galveston Tri-Weekly News, September 28, 1866, Pease papers.

${ }^{20}$ George C. Rives to Pease, November 13, 1866, William C. Phillips to Pease, January 10, 1867, James A. McKee to Pease, February 5, 1867, Pease papers. 
Orleans, and he had enough trouble keeping in contact with the cutlying areas of the Pelican state, much less than with Texas. In addition, understanding the intricacies of Louisiana politics was a full time job in itself. When Sheridan arrived to assume command of the Military Division of the Southwest in June 1865, he immediately came into conflict with Major General E. R. S. Canby. Canby was in charge of the Department of the Gulf which included the entire state of Louisiana. Sheridan's command area, however, began on the west bank of the Mississippi River and stretched to the Rio Grande. In effect, both men shared the control of most of Louisiana. Sheridan found this situation to be "anomalous" because he had received his major general's rank two years before Canby, yet he had to "request" the junior officer's approval in logistical matters. In mid-July Grant solved the problem by creating the Military Division (later Department) of the Gulf, and placing Sheridan in control of Texas, Louisiana, and Florida. Canby was to head the District of Louisiana and receive his orders from Sheridan. 21

Once he assumed over-all command of the Department of the Gulf, Sheridan was faced with a new problem. As the division commander, he was "handcuffed" to his desk in New Orleans, unable to visit Texas, the Rio Grande, or Florida or to advise his subordinates in the field. Sheridan recommended that Florida be detached from his command and replaced with Mississippi. Further, he wanted Texas made a separate department with its own commander. Instead of reducing his workload,

$21_{\text {GO }} 95$, May 17, 1865, AGO, and GO I, July 17, 1865, Military Division of the Gulf, in O..R., XLVIII, Pt. 2, 475-76, 1087. See also, Sheridan to Rawlins, July 3, 7, 1865, Sheridan to Grant, July 14, 1865, Grant papers. Emphasis in the original. 
Fifth Military District Commanders*

Maj. Gen. Philip H. Sheridan

Bvt. Maj. Gen. Charles Griffin

Bvt. Maj. Gen. Joseph A. Mower

Maj. Gen. Winfield S. Hancock

Bvt. Maj. Gen. Joseph J. Reynolds

Bvt. Maj. Gen. Robert Buchanan

Bvt. Maj. Gen. Joseph J. Reynolds

Bvt. Maj. Gen. Edward R. S. Canby

Bvt. Maj. Gen. Joseph J. Reynolds

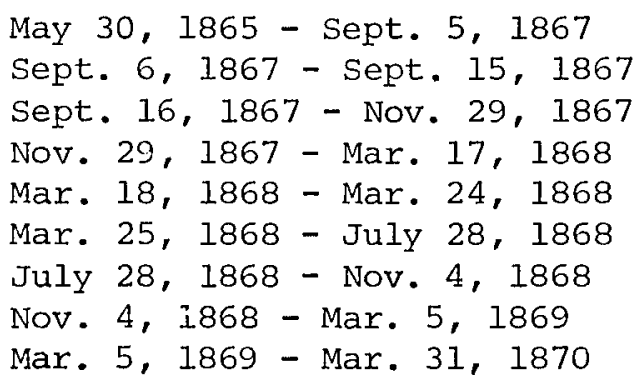

*Also Military Division of the Southwest, Division of the Gulf, Department of the Gulf.

\section{District of Texas Commanders}

Bvt. Maj. Gen. Gordon Granger

Bvt. Maj. Gen. Horatio G. Wright

Bvt. Maj. Gen. George W. Getty

Bvt. Maj. Gen. Samuel P. Heintzelman

Bvt. Maj. Gen. Charles Griffin

Bvt. Maj. Gen. Joseph J. Reynolds
June 13, 1865 - Aug. 21, 1865

Aug. 21, 1865 - Sept. 24, 1866

Sept. 24, 1866 - Oct. 24, 1866

oct. 24, 1866 - Nov. 28, 1866

Nov. 28, 1866 - Sept. 15, 1867

Sept. 16, 1867 - July 28, 1868

Governors of Texas

Andrew Jackson Hamilton

June 17, 1865 - Aug. 13, 1866

(Appointed by the President)

James Webb Throckmorton

Aug. 13, 1866 - July 30, 1867

(Elected by the People)

Elisha Marshall Pease

July 30, 1867 - Sept. 30, 1869

(Appointed by Maj. Gen. P. H. Sheridan)

Vacant - (Functions of the Office Sept. 30, 1869 - Jan. 18, 1870 Handled by Bvt. Maj. Gen. Joseph J. Reynolds)

Edmund J. Davis

Jan. 18, 1870 - Jan. 13, 1874

(Elected by the People and Appointed by Reynolds) 
however, Washington ordered Sheridan to assume the post of Assistant Commissioner of the Freedmen's Bureau for Louisiana and Texas. The exasperated department commander wrote to Grant that the new orders entailed too much work for one man. He sarcastically concluded that he fully expected to be appointed the Commissionex of Indian Affairs in Texas at any time. 22

Sheridan tried to keep in contact with affairs in Texas by making frequent journeys there but this system caused more trouble than it was worth. When he left one state, trouble started in another. The summer of 1866 was a good example. Sheridan went to Texas to confer with General Horatio Wright. He had no sooner left when New Orleans erupted in a massive race riot, and he had to rush back to Louisiana. But then United States soldiers burned down part of Brenham, Texas, in retaliation for the shooting of two of their comrades by townspeople. So Sheridan had to go back to Texas to help prevent further incidents there. All of this was in addition to his assignment to maintain American neutrality along the Rio Grande. 23 The only way for Sheridan to handle his responsibilities adequately was to appoint a reliable man to whom he could delegate all responsibility of command in the District of Texas. Sheridan needed an officer who could be trusted in a crisis and who would be as suspicious of the ex-Rebels in the state as he was. Sheridan used up five officers before he found the man he was looking for. The first

${ }^{22}$ Sheridan to Grant, August 22, 1866, Sheridan papers.

23 For a good description of events in Louisiana, see Joseph Green Dawson III, "Five Generals in Louisiana Reconstruction, 18651868" (Unpublished M.A. thesis, Louisiana State University, Baton Rouge, 1970), 13-14, 20-36. 
commander of the District of Texas was Major General Gordon Granger, who had had an excellent war record in the Western Theater. As a first move, Granger distributed the arriving Federal forces throughout the state and freed the slaves by military order. Granger, however, was too friendly with former Confederate officials. As early as May 29, 1865, when he was in command at Mobile, he had recommended to President Johnson that Alabamans immediately be restored to the Union "with their vested rights." Because of this letter, Grant held Granger suspect and asked Sheridan if the latter felt Granger's removal was advisable. Sheridan said he would be glad to see Granger leave, adding unfairly that he blamed Canby for his original appointment. When the puzzled Granger asked why he was being relieved after serving less than a month in Texas, Sheridan wrote to him that the reduction of troop strength in Texas was "probably the principle reason." 24

Granger's successor was Major General Horatio G. Wright, who headed the Department of Texas for the next twelve months. Wright had served in the Corps of Engineers until 1862 when he became a troop commander. He led a division and later the VI Corps of the Army of the Potomac. Wright was an amiable person who did his best to get along with the civil government in Texas. Wright's attitude posed no problems as long as the provisional government lasted, but it became a problem after the first election restored the former confederates to power in July 1866. Wright's continued policy of cooperation with

24 Granger to Johnson, May 29, 1865, Johnson papers; Grant to Sheridan, July 13, 1865, Sheridan to Grant, July 15, 1865, Grant papers; C/S to Granger, July 19, 1865, so 2, July 19, 1865, Military Division of the Gulf, O.R., XLVIII, Pt. 2, 1093. For Granger's military record, see Heitman, Historical Register, I, 469, and Ezra J. Warner, Generals in Blue: Lives of the Union Commanders (Baton Rouge, 1964), 181 . 
these men worried Sheridan, and when the Texas commander, after consultation with Throckmorton, suggested removing Federal forces from the state's interior to the frontier, sheridan became really alarmed. His worries were solved when Wright was mustered out of the volunteer service and assumed his old rank of lieutenant colonel of engineers. 25 Wright was replaced by Major General George W. Getty, a former division commander in Wright's old VI Corps who was previously in charge of the Sub-district of the Rio Grande. Since Getty was ill much of the one month he commanded the District of Texas, the War Department mustered him out of the volunteer service and granted him a prolonged leave of absence to cure his illness. ${ }^{26}$ The senior officer now left in Texas, Major General Samuel P. Heintzelman, assumed command immediately after Getty's departure. Heintzelman was one of the oldest officers in the entire army, having graduated from West Point in 1825. Before the war, Heintzelman had served for several years in Texas and was well-known and respected there. Once again Sheridan was saddled with an officer who extended kindness, consideration, and sympathy to the former Confederates who made up the state's civil administration. After the wearying year sheridan had just spent--going to Brownsville to stop filibuster raids, then to Galveston to check up

25 A. J. Hamilton to Johnson, July 24, 1865, Johnson papers; Wright to Sheridan, October 16, 1865, Sheridan papers; Wright to AAG, August 18, 1865, Telegrams Received, Department of the Gulf records, R.G. 303, National Archives. See also, Heitman, Historical Register, I, 1062, and Warner, Generals in Blue, 575-76.

${ }^{26}$ GO 2, September 24, 1866, GO 5, October 9, 1866, Printed Orders, District of Texas, R.G. 94, National Archives; Bvt. Maj. Gen. J. B. Kiddoo to AAG, September 16, 1866, Department of the Gulf records; Heitman, Historical Register, I, 452; Cullum, Biographical

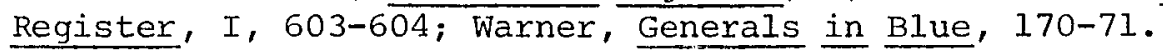


on the elections for the new civil government, then to New orleans for the July race riot, and back to Texas again for the Brenham fire--he could take no more chances. 27

When Heintzelman returned some old cannons to the city of Galveston, Sheridan went into action. With the connivance of Grant, Sheridan had Major General Charles Griffin assigned to Texas. Griffin's brevet rank was older in date than Heintzelman's, and this technically forced the latter to step down and rejoin his regiment. Heintzelman's colonelcy, however, pre-dated Griffin's. The old man was angry and puzzled as to why he should be relieved by this young upstart who was his junior in actual rank and kept under Griffin's command rather than transferred. Heintzelman wrote Senators J. R. Doolittle and Edgar Cowan and Representatives Gilman Marston and George W. Schofield. He complained that he was still a colonel and had been one since 1861 in spite of his good war record, and he asked them what he could have done wrong to deserve his recent humiliation in Texas. 28

Evidently, someone set Heintzelman straight about the realities of Reconstruction politics, for two months later he wrote a letter to Thaddeus Stevens, the Radical Republican leader in the House.

27 The feeling of Texans is well expressed in Gov. J. W. Throckmorton to Maj. Gen. S. P. Heintzelman, December 5, 1866, J. W. Throckmorton papers, Archives, University of Texas; Dallas Herald, December 19, 1866; San Antonio Express, December 13, 1866. See also, Heitman, Historical Register, I, 521; Cullum, Biographical Register, II, 295-96; Warner, Generals in Blue, 227-28.

${ }^{28}$ Grant to Sheridan, November 10, 1866, Sheridan to Grant, November 10, 1866, Grant papers; Heintzelman to Hon. J. R. Doolittle, December 12, 1866, Andrew Johnson papers; Heintzelman to Hon. George W. Schofield, January 12, 1867, Heintzelman to Hon. Edgar Cowan, January 28, 1867, Heintzelman to Hon. G. Marston, January 29, 1867, in Samuel Peter Heintzelman papers, Manuscripts Division, Library of Congress. 
Heintzelman, ordinarily a mild man, wrote a stinging attack on the civil government of Texas and the necessity of using martial law in all criminal cases. Several months later Heintzelman realized he had acted too late. He asked for and received three months' leave and was transferred to New York City and out of the Reconstruction picture. 29

In Charles Griffin, Heintzelman's replacement, Sheridan found the qualities for which he had been searching diligently. A ramrod stiff regular, Griffin had been an artillery instructor at West Point. He received a division in 1862 and served brilliantly with the Army of the Potomac. He was considered a strict disciplinarian, and his solid qualities caused Sheridan to elevate Griffin to corps command on the battlefield of Five Forks. Now, after the war, Sheridan again turned to Griffin. As one author put it, Griffin was "seemingly of [Sheridan's] own volatile and arbitrary temperament." More importantly, unlike his predecessors, Griffin "understood" the political purposes of Reconstruction. He would not hobnob with former Confederates. He would be suspicious of the intentions of the state's civil government and he would pursue the congressional policy even more enthusiastically than sheridan. 30

Shortly after Griffin assumed command, Congress passed the

${ }^{29}$ Heintzelman to Thaddeus Stevens, February 16, 1867, so 372, July 23, 1867, AGO, copy in Heintzelman papers; Grant to Sheridan, April 13, 1867, Grant papers.

${ }^{30}$ GO 10, December 1, 1866, GO 11, December 1, 1866, Printed Orders, District of Texas. Griffin's character is described in william A. Russ, Jr., "Radical Disfranchisement in Texas, 1867-1870," Southwestern Historical quarterly, XXXVIII (1934-35), 40; Bruce Catton, A Stillness at Appomattox (New York, 1954), 63-66. See also, Heitman, Historical Register, I, 478; Cullum, Biographical Register, II, 196-97; Warner, Generals in Blue, 190-91; Ramsdell, Reconstruction in Texas, 150. 
first two Reconstruction Acts. This legislation divided the South into five military districts, each commanded by a general officer of the Army. The Reconstruction Acts also allowed the Army to intervene in court cases where freedmen and Unionists had been denied justice and to supervise a new registration of voters who were to elect a new constitutional convention. The purpose of the convention was to alter the state's constitution to provide for universal male suffrage. The revised constitution would then be submitted for the approval of the people and a new government elected. When the new government was approved by Congress, it was then to ratify the Fourteenth Amendment. 31 On March 19, 1867, Sheridan issued General Orders No. 1, which announced his assumption of command of the Fifth Military District which was composed of Texas and Louisiana. Each state was to keep its present military commanders; hence Griffin retained control of the District of Texas. Sheridan declared the state governments to be provisional in nature, but he promised that there would be no wholesale removals of civil authorities from office unless the officeholders failed "to carry out the provisions of the law or impede reorganization . . . "32 Throckmorton quickly wrote both Sheridan and Griffin and announced his willingness to assist in reorganizing Texas. Sheridan curtly informed the governor that state authorities

${ }^{31}$ U. S., Statutes at Large, XIV, 428-29, ibid., XV, 2-4. See also, Sheridan to Grant, March 8, 1867, and Grant to Sheridan, March $9,13,15,1867$, Grant papers.

${ }^{32}$ GO 1, March 19, 1867, Printed Orders, Fifth Military District; Sheridan to Griffin, March 23, 28, 29, 1867, Letters Sent, Fifth Military District records. 
could help out only by supporting the Army with good feeling. 33

The Unionists lost no time in announcing their pleasure at the military's new role. They told the Army that slavery was still in existence in Texas and that loyal men had been horribly discriminated against in the courts. The Union men also complained that state offices were held by disloyal men. The Loyalists volunteered to serve as military appointees or recommended "true" men who should be considered for office. They wanted a change of affairs and awaited word from the Army on what they could do to end this Rebel stranglehold. ${ }^{34}$ General Griffin quickly acted to locate loyal men. He requested and received from Throckmorton the state records giving the names and residences of all who had been appointed to office during Hamilton's administration. As early as March 25, Griffin informed the Loyalists that if Throckmorton failed to clearly indicate that he "intends to do right," the general would remove him from office. Other "most cheering

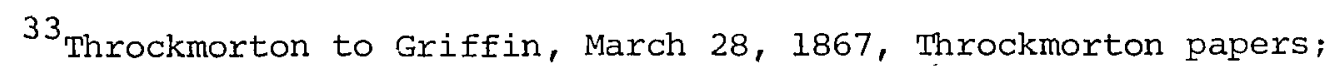
Sheridan to Throckmorton, March 29, 1867, Governor's papers (Throckmorton).

${ }^{34}$ See Jesse A. Ashbury to AAG, April 10, 1867, A. W. Bryant to AAG, May 22, 1867, Secretary of Civil Affairs to Livingston Linsay, July 1, 1867, William H. Sinclair to AAG, July 18, 1867, Letters Received, Civil Affairs, District of Texas records; B. F. McFarland to AAG, March 20, 1867, Petition of the Citizens of Tarrant County to AAG, April 6, 1867, John Plumer and others to AAG, April 16, 1867, B. F. Floydstine to AAG, August 10, 1867, ibid., Fifth Military District records; San Antonio Express, July 9, 1867; Griffin to Throck-

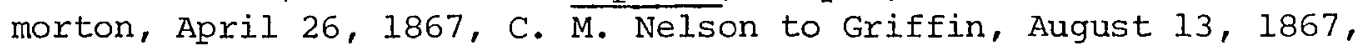
Governor's papers (Throckmorton); John Dix to AAAG, April 23, 1867, House Executive Documents, 40th Cong., lst Sess., No. 20, 90; Petition of the Citizens of Parker and Jack Counties to Griffin, April 16, 1867, "Transcript of Records, 1838-1869," Texas Adjutant General's Office records, Archives, University of Texas; W. B. Moore to AAG, March 29, 1867, Letters Received, Fifth Military District records. 
and satisfactory" interviews with Griffin established the district commander's interest in making more substantial changes in the composition of Texas civil government after Throckmorton's demise. 35 Immediate letters were sent to Elisha M. Pease urging him to return to Texas to lead the new Republican party. Equipped with a certificate authorizing him to organize Union Loyal League ${ }^{36}$ branches throughout Texas, Pease hastened home. In Houston, he presided over the first Republican convention in July 1867 which was attended by black and white delegates from twenty-seven counties. The Conservative press called it a "Radico-Congo" convention, but Pease felt such statements only showed that they feared the new party's growing power. ${ }^{37}$

Griffin was pleased with the progress made by the Republicans in the spring and summer of 1867. An informant notified Pease that "the Genera.l believes, as we do, that the car of progress has received a start in the state of Texas that is to end in the triumph of liberty and confusion to treason." The same man notified Pease that he was to be "the bulwark against which unrepentant treason is to dash itself to pieces." Unfortunately for the Republicans, however, affairs in Texas were moving too rapidly toward a quick registration and election

${ }^{35}$ Griffin to Throckmorton, April 8, 1867, "Transcript of Records, 1838-1869"; Throckmorton to Griffin, April 12, 1867, Throckmorton papers; E. P. Hunt to Pease, March 25, 1867, William Alexander to Pease, April 12, 1867, Pease papers, emphasis in the original.

36 The Loyal League was a Republican political front that organized the Negro vote in the South. See the printed form dated June 11, 1867, Pease papers.

37 S. M. Swenson to Pease, March 28, 1867, Pease to Carrie, July 11, 1867, ibid.; Paul D. Casdorph, A History of the Republican Party in Texas, $1865-1965$ (Austin, 1965), 4 4-5. 
of the new convention. One Republican organizer in Hidalgo County complained "that a Union man has no more of a chance of getting elected to office than Satan has of getting to heaven." 38

There was only one loophole in the Republican takeover. The state government was still in the hands of Governor Throckmorton who was smilingly and obediently doing all he could to assist in the registration while he obstinately criticized Army policy and quietly appointed Conservatives or authorized illegal elections to fill vacant offices. ${ }^{39}$ Throckmorton's independence irritated Griffin, and in late March he asked Sheridan to remove Throckmorton. Sheridan passed the request on to Grant, at the same time recommending the removal of the Governor of Louisiana, James Madison wells. Grant, however, demurred because he was not sure the removal power existed under the current laws. A few days later Grant changed his mind. He wrote Sheridan that he believed Congress intended that a commander should have the right of removal which, however, should be used sparingly. 40 sheridan tested Grant's theory by removing Governor Wells and the Louisiana Levee

${ }^{38}$ William Alexander to Pease, April 12, 1867, W. B. Moore to Pease, July 7, 1867, Pease papers; W. B. Thompson to AAG, May 12, 1867, Letters Received, Civil Affairs, District of Texas records. See also, Elliott, Leathercoat, 167, who hints at the practical nature of the Republicans' interest in the Negroes.

${ }^{39}$ William Alexander to Pease, April 12, 1867, Pease papers; A. W. Bryant to AAG, May 22, 1867, Letters Received, Civil Affairs, District of Texas records; GO 66, April 15, 1867, Printed Orders, District of Texas; Griffin to Throckmorton, May 4, 1867, Governor's papers (Throckmorton); Throckmorton to Uvalde County Judge, May 7, 1867, "Transcript of Records, 1838-1869."

${ }^{40}$ Griffin to Secretary of Civil Affairs, March 28, 1867, Letters Sent, Civil Affairs, District of Texas records; Sheridan to Grant, April 2, 1867, Grant to Sheridan, April 3, 1867, Johnson papers; Grant to Sheridan, April 5, 1867, Sheridan papers. 
Commission from office. These acts created such a furor that he deemed it best to refrain from removing Throckmorton lest an irate President Johnson transfer him to another post. 41

The Texas Repubiicans were dismayed at Sheridan's reluctance to act. "All depends upon Sheridan" a loyal man wrote to Pease; only Little Phil could authorize Griffin to oust Throckmorton but Sheridan refused to move against the Texas governor without a more explicit legal sanction. ${ }^{42}$ The only hope left was for Congress to grant the removal power by law. Pease recognized this when he informed his daughter that such an act would "greatly aid the Union cause in this State by placing its government in the hands of loyal men."43 Griffin also realized that Congress would have to act. "I trust so soon as the law will permit," he wrote Sheridan, "that there will be changes in the civil officers of this state." 44

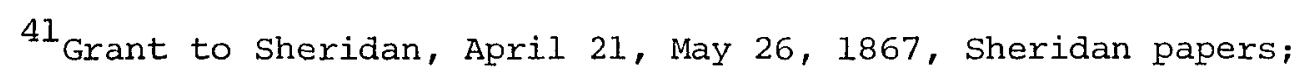
Stanton to Sheridan, June 3, 1867, Grant to Sheridan, June 7, 1867, Grant papers. Only one civil official was removed in Texas before July 30, 1867. He was Mayor J. E. Haviland of Galveston who was set aside for "contumacious conduct" on June 11. See So 109, June 11, 1867, Sheridan to Griffin, June 14, 1867, in File 57M1868, Microcopy 619, Roll 634, National Archives. All of Griffin's appointments were to fill existing vacancies. For these appointments see so 81, May 4 , so 90 , May 18, So 91, May 20, so 110, June 12, so 116, June 24, so 128, July 10, So 130, July 12, so 136, July 20, so 139, July 24, 1867, all in ibid. After July 30, Griffin removed several district judges (so 153, August 15, so 170, September 11, 1867), the rest of the state's executive officers (SO 160, August 27, 1867), and the state supreme court (so 169, September 10, So 171, September 12, 1867), and made more appointments to fill vacancies. See So 145, August 1, SO 150, August 10, SO 154, August 19, SO 165, September 4, 1867, all in ibid.

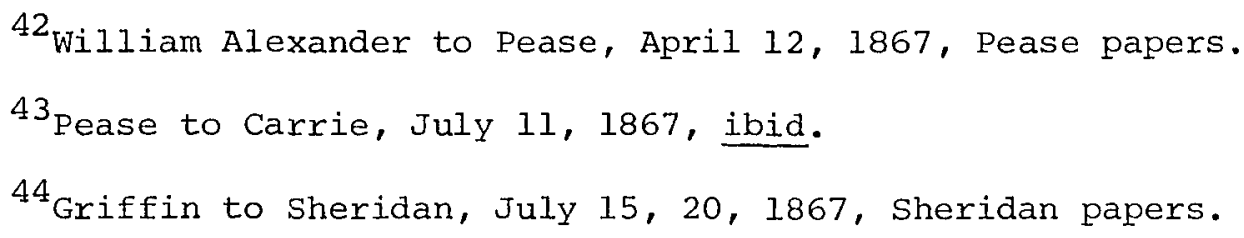


Pease and Griffin did not hope in vain, for Congress passed a third Reconstruction Act which authorized military commanders to remove any civil or military officer who obstructed the Reconstruction process. 45 Sheridan made the first removal under the new act. "A careful consideration of the reports of Brevet Major General Charles Griffin . - shows that J. W. Throckmorton, Governor of Texas, is an impediment to the reconstruction of the state, under the law; he is therefore removed from office." Sheridan appointed Elisha M. Pease as the new provisional governor--the man who had overwhelmingly lost the election that had placed Throckmorton in office one year before. 46

The Republicans in Texas were elated only momentarily. In Washington, President Johnson exercised his prerogative under the Reconstruction Acts and removed Sheridan as commander of the Fifth Military District. He appointed in his stead, Winfield Scott Hancock, a man with an enviable war record as a corps leader in the Army of the Potomac, but more importantly, a well-known Democrat. 47 The Texas Republicans had but one chance to organize their own state government. They would have to act in the interval between Sheridan's departure and Hancock's arrival from the North. Fortunately for the Republicans,

45 U. S., Statutes at Large, XV, 14-16. ${ }^{46}$ SO 105, July 30, 1867, Printed Orders, Fifth Military District.

47 The pertinent documents describing Sheridan's relief are in House Executive Documents, 40th Cong., 2nd Sess., No. 57, 3-7. Because of the intricacies of the command system, Sheridan was ordered to report to St. Louis and relieve Hancock, who commanded there. Hancock then went to Washington to consult with President Johnson before coming to New Orleans. Johnson made Hancock's appointment on the advice of Lieutenant General Richard Taylor, who had commanded the Confederate armies in Mississippi and Alabama in 1865. See Richard Taylor, Destrucm tion and Reconstruction: Personal Experiences of the Late war (New $\overline{\text { York }}, \overline{1879)}, 251$. 
Griffin, as the senior officer in the Fifth Military District, would handle both his and Sheridan's functions until Hancock arrived. He could be counted on to approve the "correct" appointments. Then Griffin suddenly succumbed to the yellow fever epidemic that was raging along the Gulf Coast. 48 The Texas Republican party desperately needed a miracle to set in motion their patronage program. It came in the person of Major General Joseph Jones Reynolds.

${ }^{48}$ GO 32, April 6, 1867, Printed Orders, Fifth Military District; AAG to Grant, September 13, 15, 1867, Bvt. Maj. Gen. A. Doubleday to Grant, n.d., Grant papers. 
VI. "WE MUST RUBB OUT AND BEGIN ANEW"

The men who made up the Texas Republican party in 1867 wanted to establish a completely new power structure in the state. "I do not adopt the cant phrase 'The Union as it was and the Constitution as it is!"" said A. J. Hamilton, "I want the Union as it wasn't and the Constitution as it Isn't." Others echoed Hamilton's sentiments. "We must have a change before we can have peace and quietness in the country," wrote M. H. Beatty to Governor Elisha M. Pease, adding that the "Modern Democracy" was a Rebel plot to "rule or ruin" the country. The only remedy was reconstruction of the state's politics and government by loyal men. "He, who occupying an official position does not aid us in spirit, is an obstruction, and ought give way (voluntarily) to those who will," thundered one irate Republican judge. As another supporter curtly phrased it, "We must rubb out and begin anew."I The Texas Republicans saw the appointment of Elisha M. Pease to the provisional governorship as the first step in the process of necessary change. "I hope Gov. Pease may be invested with full authority to make further changes among the state officials as he may deem necessary," said Judge T. H. Duval. In consultation with Pease, General Griffin slowly began to fulfill the Republicans' hopes. As

${ }^{1}$ S. M. Swenson to Pease, June 17, 1865, J. L. Haynes to Pease, November 28, 1866, W. C. Phillips to Pease, December 18, 1866, C. Caldwell to Pease, September 3, 1867, M. H. Beatty to Pease, January 12, 1867, in Pease papers. See also, undated speech, 1865, Hamilton papers. All spelling and emphasis in the original. 
much as he believed in the Texas Republicans' aspirations, Griffin could not operate freely. He was subordinate to Sheridan who refused to allow wholesale removals without specific and just cause in each case. "In this Sheridan, in my opinion, makes a great mistake," Griffin informed Pease. Neither could see why anything but party label was necessary to justify the removal of any Democrat. Not until late August 1867, did Sheridan authorize the removal of any state official who was "disloyal to the government." 2

Shortly afterwards Sheridan was set aside as commander of the Fifth Military District. His replacement, General Hancock, was a Democrat and, therefore, more of an obstacle to Republican party goals than Sheridan ever was. The Republicans expected Griffin to continue in control over the Fifth Military District until Hancock's arrival. This would allow them sufficient time to clean out the Democratic officeholders, but Griffin's sudden death dashed their hopes.

The new ad interim head of the District of Texas was Major General Joseph Jones Reynolds. Born in Kentucky, Reynolds was graduated from West Point in 1843. He served in the Army until 1857 when he resigned to assist in the family grocery business in Indiana. The war saw Reynolds rise rapidly from regimental to corps command in the Western Theater where he was breveted for heroic action at Chickamauga and Missionary Ridge. He became the colonel of the Twenty-sixth

2T. H. Duval to John Hamilton, Hamilton papers; Pease to AAG, August --, 1867, Letters Received, Fifth Military District records; Griffin to Pease, August 15, 1867, Pease papers; Sheridan to Griffin, August 27, 1867, File 57M1868. Griffin made most of his removals and appointments after August 27. See so 160, August 27, so 165, September 4, So 169, September 10, so 170, September 11, SO 171, September 12, 1867, all in ibid. 
Infantry in 1866 and was assigned to the Sub-district of the Rio Grande. ${ }^{3}$

As Griffin's replacement, Reynolds was the key to Republican success or failure in their patronage program. The outlook, however, was very gloomy for them. Reynolds had been an extremely popular officer in Brownsville, close to the people and highly praised by that uncompromising archenemy of Reconstruction, the Brownsville Daily Ranchero. "I do not know what to advise our friends in Texas to do except to prepare (secretly) for defense," a worried A. J. Hamilton informed his brother. ${ }^{4}$

Reynolds received his appointment on september 17 and assumed command of the District of Texas four days later. He temporarily established his headquarters at Austin because the yellow fever epidemic along the coast made travel to Galveston perilous. ${ }^{5}$ seeking to make a good impression on Reynolds, Republican leaders consulted with friendly local commanders and asked them to present the party's program to him. ${ }^{6}$ The first sign of hope came soon after Reynolds' arrival in

$3_{\text {Heitman, Historical Register, I, 825; Cullum, Biographical }}$ Register, II, 78-79; Warner, Generals in Blue, 397-98.

4 For Reynolds' send-off from Brownsville, see Brownsville Daily Ranchero, September 29, 1867. See also, A. J. Hamilton to M. C. Hamilton, september 22, 1867, Hamilton papers.

$5_{\text {SO }} 141$, September 17, 1867, Printed Orders, Fifth Military District; GO 31, September 21, GO 36, October 14, 1867, Printed Orders, District of Texas; J. J. Reynolds to AAG, October 4, 1867, Telegrams Received, Fifth Military District records; AAG to Reynolds, November 13, 1867, Telegrams Sent, ibid.

6E. Degener to Pease, September 24, 1867, Pease papers. There was close cooperation between the Army and Austin. Local commanders continually recommended "loyal" men, warned against doubtful appointments, and exposed "Rebel" officials which gave them important control over patronage. See Capt. T. S. Post to A. J. Hamilton, August 30 , 
Austin when his Secretary of Civil Affairs ${ }^{7}$ wrote Governor Pease to ask his advice on a list of names submitted for appointments. ${ }^{8}$ One month later the alliance between Reynolds and the state executive was completed.

Pease indicated his trust in Reynolds in a proclamation issued on October 25. He declared that the powers of his government rested on the March Reconstruction Acts, Sheridan's orders placing these acts into effect, the July Reconstruction Act, and any oxders promulgated by the head of the Fifth Military District. There was no "legal" state government of Texas, continued Pease, but he would allow the laws of Texas existing in March 1867, except those that had been nullified by Congress, to continue in effect. Those persons in office when the

1865, Governor's papers (Hamilton); Robert K. Smith to Judge [James H. Bell], November 14, 1867, James H. Bell papers, Archives, University of Texas; William H. Sinclair to Pease, December 4, 1867, Pease papers; Thomas J. Loader to AAG, February 11, 1869, Letters Received, Fifth Military District records; Second Lt. G. E. Overton to AAG, October 23, 1869, ibid., Civil Affairs; AAAG to Alexander McCoppin, April 29, 1869, Letters Sent, Fifth Military District records; Secretary of Civil Affairs to Mayor of Town of Travis County, June 4, 1869, Secretary of Civil Affairs to Post CO, Austin, June 11, 1869, Civil Affairs. The local $\mathrm{CO}$ could also allow citizens to recommend appointments in town meetings, Georgetown Watchman, April 17, 1869. Pease and the military exchanged over fifty letters concerning appointments. See, e.g. , Pease to AAG, March 25, 1868, Letters Received, Civil Affairs, Fifth Military District records. Functions of governor and military commander were so similar that appointment requests were addressed to both men. See Citizens of Jefferson to Pease and Reynolds, June 19, 1868, Governor's papers (Pease).

7 The Secretary of Civil Affairs had the responsibility of informing candidates of their appointment, receiving oaths of loyalty, paying registrars of voters, explaining the Reconstruction laws to local authorities, declaring election results, and supervising local government. The Secretaries also handled the enforcement of law and order and military trials of civilians.

${ }^{8}$ Secretary of Civil Affairs to Pease, September 27, 1867, Letters Sent, Civil Affairs, District of Texas records. 
March Reconstruction Acts were passed and who had not been removed were the representatives of the provisional government. 9

The Proclamation of October 25 was Pease's way of recognizing the Army's supreme control in the state, something both Hamilton and Throckmorton had denied. In addition, Pease adopted the military's interpretation of the validity of all laws passed since secession except those held null and void by Federal laws. In this matter, Pease challenged the ab initio faction of his party and initiated a split that caused trouble in the constitutional convention and the election of 1869. The governor also ordered all state officials to obey the principles set forth in the proclamation. ${ }^{10}$

In exchange for the governor's proclamation, Reynolds agreed to appoint a Republican administration before Hancock's arrival. Reynolds was able to keep his end of the bargain because the yellow fever epidemic delayed Hancock's arrival. The Army had already lost one general because of the disease and was not willing to risk Hancock's life unnecessarily. The new temporary head of the Fifth Military District, Major General Joseph A. Mower who commanded the Department of Louisiana, wrote to Grant and recommended that Hancock stay in Amite, Louisiana, until it was saie to come into New orleans. Grant decided instead to keep Hancock in St. Louis until mid-October. He later extended his

${ }^{9}$ Republican leaders had suggested that Pease deliver such an "inaugural address." See C. Caldwell to Pease, September 3, 1867, Pease papers. For the Proclamation of October 25, 1867, see Executive Correspondence.

10 Hamilton's concept of military rule is revealed in his letter to Maj. Gen. N. J. T. Dana, December 20, 1863, and his speech of February 9, 1867, both in Hamilton papers. See also, Ramsdell, Reconstruction in Texas, 178-79. 
stay there to the end of November. ${ }^{11}$

Mower, like Sheridan, became so involved in Louisiana politics that he had little time for Texas matters, and he received no reports from Reynolds. Mower, and thus Grant, knew only that Reynolds was rumored to have replaced some Texas officials. When Reynolds finally communicated with New Orleans, he received Mower's permission to remove several state judges, district attorneys, and the state attorney general. 12 Mower himself replaced some Louisiana civil authorities. When Grant heard of Mower's action, he telegraphed a new order to suspend all removals until Hancock arrived; Mower complied. 13

Because of Mower's preoccupation with Louisiana, Reynolds was free to live up to his agreement with the Texas Republicans. By October 20 he had appointed thirty-three men to vacant offices, perhaps to indicate his good will to Pease. A week after Pease issued his proclamation, Reynolds announced Special Orders No. 195, a thirteenpage document that removed 400 Democrats from office and appointed 436 Republicans. ${ }^{14}$ During the next six days, the general appointed

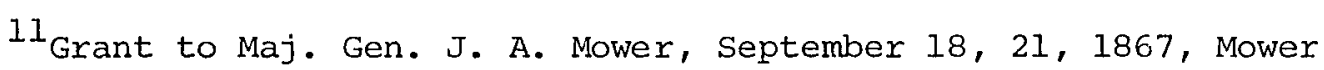
to Grant, September 16, 19, 1867, Grant papers.

12 Mower to Grant, September 18, 1867, Mower to C. B. Comstock, October 21, 1867, Grant to Mower, November 2, 1867, ibid.; AAG to Reynolds, November 5, 8, 1867, Telegrams Sent, Fifth Military District records; Reynolds to AAG, November 13, 1867, Telegrams Received, ibid.; Secretary of Civil Affairs to Reynolds, November 15, 1867, File 57M1868. It was not unusual for Galveston and New Orleans to fail to keep in touch. See Reynolds to AAG, February 18, 1868, Letters Received, Fifth Military District records; PAG to Reynolds, February 24, 1868, Letters Sent, ibid.

13 Grant to Mower, November $22,25,1867$, Mower to Grant, November 22, 1867, Grant papers.

${ }^{14}$ SO 192, October 20, SO 195, November 1, 1867, File 57 M1868. 
Republican officials to the city governments of San Antonio and Austin and filled eighty-eight miscellaneous state offices, removing the incumbents from all but fourteen of the latter. After a brief respite, the commander of the District of Texas struck again. Between November 18 and the end of the month, he appointed eighty-seven more men to local government jobs, twenty-five of which had been vacant. The miracle had happened; the Republicans were entrenched in state government as never before. 15

Reynolds did not act a day too soon because Hancock finally arrived on November 28. The new commander was a native of Pennsylvania and graduated from West Point in 1844. He sexved in the Mexican War as an infantry lieutenant and on the frontier primarily as a quartermaster. During the war, he had a meritorious career with the Army of the Potomac, rising from brigade to corps command. Hancock was instrumental in saving the Union army on the first day at Gettysburg, and his corps bore the brunt of the fighting of the next two days, during which he received a serious hip wound. He later returned to action and led his corps in the 1864 campaign against Richmond until his old wound reopened. Because of his fine record, Congress made Hancock the junior major general in the Army in 1866. The general served as

${ }^{15}$ SO 197, November 4, SO 198, November 5 , so 199 , November 7 , So 206, November 18, So 207, November 19, SO 209, November 21, so 210, November 22, 1867, ibid. Ramsdel1, Reconstruction in Texas, 181, speaks of the wrong man when he notes that Mower followed "a more moderate policy" than Sheridan. In actuality, Reynolds swept the Democrats out of office more thoroughly than Sheridan had ever dreamed. Even Griffin looked mild by comparison, although he probably would have followed the same policy as Reynolds. Removals and appointments are listed by county in the ledgers marked "Election Register, 18661870," Archives, Texas State Library, and "Civil Officers, Texas," R.G. 393, National Archives. 
commander of the Department of the West until he was assigned to the Fifth Military District. 16

Hancock formally took command at New Orleans on November 29. His first act was to replace Mower with Major General Robert C. Buchanan; this was done because Mower's effectiveness supposedly had been impaired when Grant told him to reinstate several deposed Louisiana officeholders. ${ }^{17}$ The officials set aside by Reynolds in Texas had been eagerly awaiting a similar reprieve. Upon Hancock's assumption of command, they flooded the Fifth Military District headquarters with angry letters protesting Reynolds' action. Many of these complaints referred to Reynolds' removal of Judge James Love of the criminal court of Galveston and Harris counties. The bar associations of Galveston and Houston both attested to the judge's competency for the bench. Governor Pease, however, said that before the war the Texas bar had considered Love an incompetent judge and had forced him to resign. The governor marvelled at how their tone had changed. He assured Reynolds that Love and the bar associations' members were former Confederates, and Love's successor was a "thoroughly loyal and educated gentleman." Reynolds sent Pease's remarks to New Orleans, adding that Love's legal background was irrelevant since he was disqualified from holding office because he could not take the oath. ${ }^{18}$

16 Heitman, Historical Register, I, 496-97; Cullum, Biographical Register, II, 108-109; Warner, Generals in Blue, 202-204.

${ }^{17}$ Grant to Maj. Gen. W. S. Hancock, September 11, 15, November 29, December 3, 1857, Grant to Mower, November 27, 1867, Mower to Grant, November 27, 1867, Hancock to Grant, September 11, 14, November 28, 29, December 2, 1867, Grant papers. See also, GO 40, November 29, 1867, Printed Orders, Fifth Military District.

${ }^{18}$ Judge Love's case is in A. N. Morrison and 32 others to Han- 
Prompted by the various complaints, Hancock demanded that Reynolds detail his power and justification for the removal of so many state officials. At the same time, he ordered Reynolds to make no further changes in civil officials and permit those who had been removed (but who still physically held their offices) to remain in their positions. After an extended delay, Reynolds finally explained his course of action. The replacements had been made "after consultation with Governor Pease and were based on written evidence in this office," said Reynolds. He admitted that he did not know any of the men involved nor had he seen all of the evidence. His basis for acting without Hancock's authorization was Sheridan's letter of August 27 to Griffin in which Little Phil had told Griffin to remove all disloyal persons from office. Reynolds also believed he had proper authority under the Reconstruction Acts to eliminate any officeholder who tried to "hinder, delay, prevent, and obstruct" the laws of Congress. 19 The Democrats in Texas were not satisfied with this explanation, and they pressured Hancock to reverse the November office changes. They also indicated that they believed Reynolds should follow Mower to another assignment. The Brownsville Daily Ranchero, happy with Rey-

cock, December 4, 1867, William H. Crook and 14 others to Hancock, November 27, 1867, Pease to Reynolds, December 27, 1867, Reynolds' endorsement of the same letter, December 30, 1867, all in File 57M1868. For other removal protests, see also, George T. Todd to Hancock, December 9, 1867, M. H. Roysten to I. W. Harris, January 8, 1868, in ibid.; T. T. Gammage to AAG, December 12, 1867, Pease papers; N. L. Hancock and others to Hancock, January 1, 1868, Governor's papers (Pease).

${ }^{19}$ Secretary of Civil Affairs to Reynolds, December 4, 1867 (two messages), Telegrams Sent, Civil Affairs, Fifth Military District records; Reynolds to Hamilton, December 30, 1867, Reynolds to AAG, December 31, 1867, File 57Ml868. 
nolds in September, now crucified him. "We sincerely hope that Major General Hancock may find a retired spot in the corner of New England for that pious, double-faced, double-dealing, smiling, fawning, sycophantic Maj. Gen. Reynolds, by brevet," said the Ranchero. The Democratic organ laughed at Reynolds because he claimed to be a Douglas Democrat. "Hell is full of such democrats [sic]. He is a spy, and a lying spy on the people of the South," charged the Ranchero. The paper bemoaned the fact that Reynolds was "now the law-maker, lawgiver, judge, jury, pettifogger, and teazer over the whole state of Texas." 20

Unsure of how far he should go in disciplining Reynolds, Hancock wrote to Grant and explained the whole situation. Grant approved limiting Reynolds' right to make further removals, but he felt it would be wise to confirm the appointments already made. ${ }^{21}$ Hancock followed Grant's advice but told the complaining Texas Democrats he could not act in their behalf because the Reconstruction Acts prevented reappointment of an official once removed. ${ }^{22}$ Although Hancock refused to replace local officials for political reasons, he did appoint some ninety-odd men to offices already vacant. 23

${ }^{20}$ Samuel L. Earle to Pease, January 29, 1868, Citizens of Dallas to Pease, February 25, 1868, Governor's papers (Pease); Brownsville Daily Ranchero, December 11, 1867.

${ }^{21}$ Hancock to E. D. Townsend, January 11, 1868, Grant to Hancock, January 13, 1868, Grant papers.

22 Secretary of Civil Affairs to T. T. Gammage, John J. Good, James Love, January 2, 1868, Secretary of Civil Affairs to T. J. Jennings, H. A. Stanley, January 6, 1868, Letters Sent, Civil Affairs, Fifth Military District records.

23"Election Register, 1866-1870," 1ists Hancock's appointees. See also, so 16, January 22, so 18, January 25, so 44, February 27 , 
If Hancock did not overtly change the situation in Texas, he did bring into effect a new spirit of administration. Hancock had no desire to command the Fifth Military District because he knew that his feelings on Reconstruction differed from those expressed by the Reconstruction Acts. President Johnson, however, appointed him for just that reason. On his trip south, the new commander voiced his apprehensions to his wife several times. "I am expected to exercize extreme military authority over these people," Hancock told her. "I shall disappoint them." The general said that he had not been educated to overthrow civil authorities in time of peace, and that he intended to issue a proclamation to that effect. He also expressed his fear that he might lose his commission, but he would rather do that than "retain it at the sacrifice of a life long principle." The night before he arrived in New Orleans, the general stayed up until 4:00 a.m. working on his proclamation. Gazing at the finished product, he sighed to his wife, "They will crucify me." Hancock knew President Johnson was on his side, but he also realized that Johnson could do little to help him survive the impending political attack. ${ }^{24}$

On November 29, 1867, Hancock issued his proclamation as General Orders No. 40. The general announced his assumption of command and stated his principles. Hancock declared that he regarded "the maintenance of the civil authorities in the faithful execution of the

So 48, March 3, So 62, March 24, so 89, April 25, 1868, Printed Orders, Fifth Military District. Hancock's desire to stay clear of politics is expressed in Secretary of Civil Affairs to Reynolds, January 30 , 1868, Letters Sent, Civil Affairs, Fifth Military District records. ${ }^{24}$ Hancock to Grant, January 27, 1867, Grant papers; A. R. Hancock, Reminiscences of Winfield Scott Hancock by His Wife (New York, 1887), 120-24. 
laws as the most efficient [thing to do] under existing circumstances." The war was over and it was time for the civil authorities to exercise full power. "The right of trial by jury, the habeas corpus, the liberty of the press, the freedom of speech, the natural rights of property must be preserved," continued the proclamation. If the civil authorities proved themselves unequal to the task before them, the general pledged military action to insure "the liberties of the people . . . ."25

Hancock refused to compromise on the principles enunciated in General Orders No. 40. When Governor Pease tried to obtain a military trial for three men accused of murder in Uvalde County, Hancock demurred even though it was doubtful that the prisoners could be held long enough for the civil processes to take effect. The general noted that the right of organizing military commissions was "an extraordinary power" to be used only in the "extraordinary event that the local civil tribunals are unwilling or unable to enforce the laws against crimes." Hancock did not find Texas civil authorities unwilling to hold fair trials and refused the request for a military court. He suggested that if an unfair trial was feared in Uvalde, the local judge could grant a change of venue under Texas law. If an escape from jail were feared, the courts should ask the Army to hold the prisoners until their trial could be scheduled. If more judges were needed to fill existing vacancies and help end the legal backlog, Hancock would make the necessary appointments. Until the civil outlets had been exhausted, however, the military would not interfere directly with the courts,

${ }^{25} \mathrm{GO} 40$, November 29, 1867, Printed Orders, Fifth Military District. 
concluded the general. 26

A few days after he wrote Pease, Hancock publicly condemned petitions sent to his headquarters which implied that he had the right to make arbitrary law in civil controversies. "One petitioner solicits this action, another that, and each refers to some special consideration of grace or favor which he supposes to exist, and which should influence this department," he said. "The rights of litigants do not depend on the views of the general . . ," concluded the order. "Arbitrary power,, such as he has been urged to assume, has no existence here. 27

On receiving Hancock's letter of December 28 and the new order, Governor Pease quickly fired an irate missive back to Hancock. The governor denied that Texas was in "full exercize of its proper powers." According to the acts of Congress, said Pease, there was no legal state government in Texas and any civil government which did exist was fully subordinate to the Fifth Military District. Therefore the general in New Orleans was the true executive head of Texas government. Then Pease challenged Hancock's assertion that Texas was in a time of "profound peace." A large majority of the white population was embittered against the United States, said the governor, and this made it hard to enforce criminal laws in the state. Often civil officers refused to act or could not act because of continual intimidation. Pease blamed "a perceptable increase of crime, and manifestations of

${ }^{26}$ See Secretary of Civil Affairs to Pease, December 28, 1867, in The Civil Record of Major General Winfield Scott Hancock, During His Administration in Louisiana and Texas (n.p., 1871), 18-21. District.

${ }^{27}$ GO 1, January 11, 1868, Printed Orders, Fifth Military 
hostile feelings" directly on Hancock's attitude as commanding general. 28

Hancock temporarily ignored the governor's letter and continued to exasperate the Texas Republicans. On January 21 the general left New Orleans to make a personal inspection of the Long Horn State. Pease disgustedly told his daughter of the reception Hancock had received in Austin where more Rebels had attended than Republicans. "The former expect great things from him," said Pease. There had been rumors to the effect that Hancock would remove both Pease and Reynolds, but the governor felt that Hancock would be superseded first by "some officer whose feelings are more in sympathy with the Union men of Texas. "29

Back in New Orleans, Hancock continued his crusade against military intervention in local government. When a Freedmen's Bureau agent tried to secure military trials in his jurisdiction, Hancock refused because the agent made "only vague and indefinite complaints." He promised to consider any particular case on its mexits, but the Recon-

28 Pease to Hancock, January 17, 1868, in House Executive Documents, 40th Cong., 3rd Sess., No. 1, 268-71. Hancock was incensed at Pease's accusation that $G O 40$ had caused an increase in crime. He tried to get more facts on the situation from Reynolds, but the latter evaded the question by sending incomplete information. See Hancock to Reynolds, January 30, February 12, 1868, Telegrams Received, Civil Affairs, Fifth Military District records. The governor claimed that "over 100" cases of homicide had occurred in 1867, while the constitutional convention maintained that 331 cases occurred during the same year. Neither of these figures is really very large when compared to Benjamin C. Truman's assertion that Texas averaged 450 murders each year before the Civil War. See Pease to Hancock, January 17, 1868, ibid.; Journal of the Reconstruction Convention, Which Met at Austin,

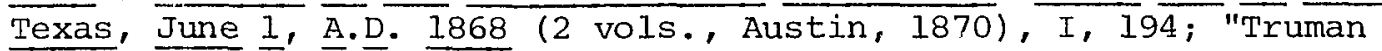
Report," Senate Executive Documents, 39th Cong., lst Sess., No. 43, 11.

29 Pease to Carrie, January $25,1868, C$. Caldwell to Pease, January 26, 1868, Pease papers; Hancock to Grant, January 21, February 3 , 1868, Grant papers. 
struction Acts gave the district commander "the duty of protecting all persons in their rights and property," said Hancock, including former Rebels. 30

Then Hancock again gave his attention to Governor Pease. "Your communication of 17 th January last was received in due course of mail," began Hancock, ". . but not until it had been widely circulated by the newspaper press." The general asserted that he replied "as soon as leisure from more important business would permit." Hancock admitted he had full power over civil affairs in Texas and the right to order a military trial. He believed, however, that "the power to do a thing . . and the propriety of doing it, are often very different matters." The main complaint that Pease had against the people of Texas, said Hancock, was that they did not agree with the governor's political views. "It would be difficult to show that the opponents of [the] government in the days of the elder Adams or Jefferson, or Jackson, exhibited for it either 'affection' or 'respect,'" continued Hancock. 31

Since the war had been over for two years, Hancock felt it was time "to tolerate again free, popular discussion, and extend some forebearance and consideration to opposing views." As for the lawlessness in Texas and the failure of officials to arrest, indict, and convict, Hancock said, "there is no place in the United States where it might not be done with equal propriety." Hancock was not going to annul

30 Hancock to Maj. Gen. O. O. Howard, February 24, 1868, in The Civil Record of Major General . . Hancock, 29-30.

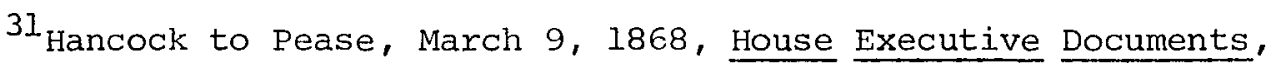
40 th Cong., 3rd Sess., No. 1, 262-63. 
the state civil code to attain law and order. The general also asserted that many of the officials refusing to act to preserve the peace were recent Republican appointees. Hancock denied that his General Orders No. 40 had caused any increase in disorder in Texas. It had been issued in the last days of November, said the general, and Pease had not yet had enough time to fully and accurately ascertain its effect. Besides, all the order had done was declare "the great principles of American liberty." 32

Hancock professed to find little in Pease's letter "but indications of temper lashed into excitement by causes which I deem mostly imaginary, . - an intolerance of others, [and] a desire to punish the thoughts and feelings of those who differ with you . . ." Above all, the general was dismayed at Pease's "most unsound conclusion that while any persons are to be found wanting in affection or respect for the government, or yielding it obedience[r] from motives which you do not approve" they should be submitted to martial rule. 33

Hancock's biographers consider his general orders and the March 9 letter to Pease to be heroic documents that guarantee fundamental civil liberties. ${ }^{34}$ This analysis of Hancock, however, ignores

$$
\begin{aligned}
& 32 \text { Ibid., 264-67. } \\
& 33 \text { Ibid., 267-68. }
\end{aligned}
$$

${ }^{34}$ Augustus T. Freed, Hancock: The Life and Public Services of Winfield Scott Hancock (Chicago, 1880), 84-85; John W. Forney, The Life and Military Career of Winfield Scott Hancock . . (Rochester, New York, 1880), 233-35; Frederick 0. Goodrich, The Life and Public Services of Winfield Scott Hancock, Major General, U. S. A. (Boston, 1880), 240-49, 285, 299, 301; "The Civil Record of Major General Winfield S. Hancock During His Administration in Louisiana and Texas," Southern Review, IX (1871), 907-908, 912; Francis A. Walker, General Hancock (New York, 1894), 299-302. Most of the works 1isted above were written when Hancock ran for President. The same theme, however, 
his interference with the attempts of Texas and Louisiana Republicans to build up their party through military patronage. By avoiding any Army intervention in the status quo and insisting that civil authorities assume full responsibility for governing their areas, Hancock maintained Conservatives in power. James Marin, a special agent for the Treasury Department in New Orleans, recognized this fact when he informed President Johnson that "Gen. Hancock's influence is most decidedly felt in our favor." Marin realized that the general, by avoiding military interference in politics, could act in the name of civil liberties--the rights of free speech, free press, trial by jury, and open dissent--to prevent further changes in the composition of local government. 35

Believing in a restricted role for the Army in Reconstruction, Hancock naturally turned the military to other fields of activity. In Texas, he concentrated on planning frontier defense against Indian attacks, and directed the construction of Forts Concho, Richardson, Griffin, and Burnham. He also ordered the Army to establish a defense line stretching from the new forts to the Rio Grande. Smaller picket details were placed at Forts Chadbourne, Phantom Hill, and Belknap. Hancock ordered Reynolds to shift the infantry "to the points most

prevails in more modern studies. See William John Ulrich, "The Northern Military Mind in Regard to Reconstruction, 1865-1872: The Attitudes of Ten Leading Union Generals" (Unpublished Ph.D. dissertation, Ohio State University, Columbus, 1959), 48-49, 67, 75; and Glenn Tucker, Hancock, The Superb (Indianapolis, 1960), 279-80. Tucker $(337 \mathrm{n}$. 21) theorizes that Hancock's Reconstruction plans were influenced by possible discussions with Lincoln during the war. This ignores Hancock's affiliation with the Democratic party which determined most of his ideas. Hancock was not really interested in justice, but rather in increasing his party's political strength in future elections.

35 James Marin to Johnson, February 21, 1868, Johnson papers. 
likely to be required for the performance of its legitimate duties." This involved moving the Twenty-sixth Infantry to the Rio Grande Valley and forwarding the Seventeenth and Forty-first (Colored) regiments to the frontier. Hancock sent all of his cavalry to the west and ordered that no other work but frontier duty be required of it. Reynolds, however, delayed the troop movements as long as possible and thus negated some of their effect. 36

Congressional Republicans soon began to scheme for Hancock's removal, but were not sure how to proceed. The senate considered a bill that would reduce the number of generals in the Army by retiring the last ones on the list. As the major general with the least seniority, Hancock would have lost his commission. This attempt died in committee, however, when party leaders detected signs that Hancock might become not only a martyr but also a serious Democratic contender for the presidency in 1868. As President Johnson was happy with the general's policies, the only other way to secure Hancock's removal was to force his resignation. 37

Hancock conveniently provided the Republicans with the issue they needed by removing the New Orleans city council for holding an unauthorized election. At first Grant had approved the action but ten

36 See Hancock to Grant, February 3, 6, 1868, Grant to Hancock, February 3, 1868, Grant papers; so 27, February 6, 1868, Printed Orders, Fifth Military District. The troop movements are described in so 37 , February 27, So 38, February 28, so 39, March 3, so 40, March 4, 1868, in ibid. See also, AAG to Reynolds, February 11, 1868, Letters Sent, Fifth Military District records; Hancock to Reynolds, March 14, 1868, Telegrams Sent, ibid. The latter telegram was sent the day before Hancock was relieved.

${ }^{37}$ Hancock, Hancock, 127-28; The Civil Record of Major General . . Hancock, 30-31; Congressional Globe, 40th Cong., 2nd Sess., $1867-68, \mathrm{XXXIX}$, Pt. $1, \overline{491 .}$ 
days later he ordered the council's reinstatement. Grant reasoned that Hancock's General Orders No. 40 expressly stated that civil authority had been restored in the Fifth Military District; this gave the council the power to call an election. For Hancock to interfere, said Grant, was to deny the veracity of his own order. Hancock could do nothing but reluctantly obey the command. Shortly thereafter Grant refused to allow Hancock to remove the New Orleans street commissioner. Hancock protested and wired the full particulars of the case to washington. Grant told him to stop using the telegraph and resort to the mails when "there is not a greater necessity for prompt reply than seems to exist in this case." with his authority so severely compromised, Hancock asked for reassignment and left for Washington on March 14.38

When Hancock departed, Major General Robert C. Buchanan became the senior officer in the Fifth Military District. Buchanan was an old regular officer whose career was very similar to that of General Heintzelman. Graduated from west Point in 1831, Buchanan had fought in the Black Hawk War, the Seminole War of the 1830's, and the Mexican War. During the Civil War he had commanded the Regular Brigade of infantry in the Army of the Potomac. His military record was highlighted by incidents of bravery and numerous brevets; however, his regular rank was only that of colonel. Like Heintzelman, he was another old-timer who had been passed over in favor of younger heroes during the war. Buchanan had replaced Mower as head of the Department

38 Hancock to Grant, February 7, 9, 11, 27, March 15, 1868, Grant to Hancock, February 8, 11, 24, 29, March 14, 15, 1868, Rawlins to Hancock, February 21, 28, 1868, Johnson papers; Hancock to AG, USA, February 27, 1868, in The Civil Record of Major General . - Hancock, 31. 
of Louisiana in December 1867 and, when Hancock left for Washington, he naturally expected to assume command. 39

The adjutant of the Fifth Military District, however, mistakenly assumed Reynolds to be the senior officer and ordered him to replace Hancock. President Johnson intervened upon Hancock's request and appointed Buchanan commander of the Fifth Military District. When Reynolds arrived in New Orleans, he found a copy of the order assigning Buchanan to command. He was enraged at the maneuvering that had gone on behind his back and stated that the whole process was unfair and illegal. Rather than create trouble, Reynolds returned to Texas and satisfied himself with a letter to the Adjutant General's office in Washington requesting it to take such action "as the good of the service demanded." 40

Buchanan's replacement of Reynolds had little effect in Texas even though Buchanan announced that he would continue Hancock's policy of no interference with civil authorities. Iike Mower, Buchanan was more interested in Louisiana and he was unfamiliar with the strange names, places, and events across the Sabine. Louisiana politics were especially demanding that spring of 1868 because the state was completing the final steps required by the Reconstruction Acts for readmission to the Union. Once again Texas was placed in the hands of

\footnotetext{
${ }^{39}$ Heitman, Historical Register, II, 258; Warner, Generals in Blue, 48-49.

40 See Hancock to Grant, March 15, 1868, Grant papers. The other events are related in GO 14, March 16, GO 15, March 18, GO 16, March 28, 1868, Printed Orders, Fifth Military District; Reynolds to AG, USA, March 24, 1868, Telegrams Sent, Fifth Military District records; Reynolds to AGO, March 30, 1868, Letters Sent, District of Texas records.
} 
Reynolds and Pease, and they immediately began rebuilding the Republican party. 41

Buchanan stayed out of Texas affairs until Governor Pease made the mistake of questioning the loyalty of Buchanan's appointee as mayor of Jefferson. Buchanan indignantly stated that he approved of nearly all of the appointments suggested by Reynolds and Pease, who had recommended whatever public officers were disloyal and incompetent. Buchanan also complained that pease saw loyalty only as a party label, not as a characteristic of any efficient officeholder. He further objected to the manner in which Pease was willing to overlook state residence requirements in selecting "loyal" appointees. Buchanan admitted that military appointees did not have to satisfy residence rules but he felt it best to follow the state law as closely as possible. Accordingly, Buchanan removed several Republican officeholders over Pease's violent protests and ordered the governor to submit a list of all state officials who lacked proper residence requirements along with comprehensive reasons why they should be retained in office. Buchanan also hinted that pease might be his next victim. ${ }^{42}$ Fortunately for Pease, Buchanan's reign was cut short by

\footnotetext{
${ }^{41}$ Reynolds made a total of 759 appointments according to "Election Register, 1866-1870," in the Texas State Archives. The "Civil Appointments, Texas" volume in the National Archives 1ists 1,176 appointments for Reynolds during the same period, september 16, 1867 to November $4,1868$.

42 Maj. Gen. R. C. Buchanan to Grant, May 16, 1868, Grant to Buchanan, May 8, 1868, Grant papers; Buchanan to Rawlins, July 18, 1868, Secretary of Civil Affairs to Pease, July 24, 1868, Letters Sent, Civil Affairs, Fifth Military District records. For Buchanan's removals and appointments, see so 93, April 30, so 95, May 2, so 103, May 12, so 120, June 1, so 147, July 1, so 148, July 3, so 158, July 17 , 1868, Printed Orders, Fifth Military Distxict. Buchanan made 171 appointments, see "Election Register, 1866-1870."
} 
Louisiana's readmission to the union on July 28. The general was retained in New Orleans as the commander of the new Department of Louisiana and Arkansas. The Fifth Military District now consisted only of Texas, commanded by General Reynolds. To more fully control the state, Reynolds permanently moved his headquarters from Galveston to Austin. There was much Democratic deadwood for the Republicans to rout out of Texas government, and the general commanding would not let the Republican party down. 43

43 Grant to Buchanan, June 26, 1868, Grant papers; Go 55, July 28, 1868, AGO, in American Annual Cyclopaedia (1869), 42; GO 1, August 10, 1868, so 1, August 10, 1868, Printed Orders, Fifth Military District. 


\section{INDUSTRIOUSLY MANIPULATED}

The Reconstruction Acts prescribed that one of the principal responsibilities of the district commander was to secure a registration of voters who could then proceed to elect a constitutional convention. In Texas, the search for qualified registrars began in March 1867, but the actual registration did not commence until May because Sheridan wanted first to consult with General Griffin. The latter feared that the "disloyal" Throckmorton would make the enrollment of voters difficult but, to his surprise, the governor cooperated fully in obtaining the names of qualified registrars. Griffin was able to establish a registration board at nearly every county seat so that few potential voters had to travel over twenty miles to register. ${ }^{1}$

The greatest problem in the registration process was the nebulous language of the Reconstruction Acts. This made it almost impossible for the Army to know exactly what could disqualify a man from registering. Sheridan requested advice from Grant, who told Sheridan to act on his own judgment until an advisory opinion could be obtained from U. S. Attorney General Henry Stanbery. Little Phil decided to

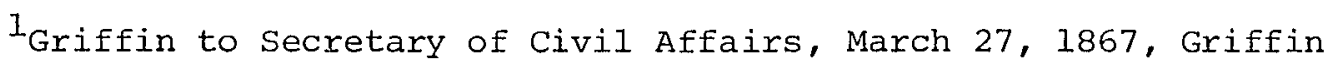
to Sheridan, March 30, 1867, Letters Sent, Civil Affairs, District of Texas records; Sheridan to Grant, April 12, 1867, Grant papers; printed circular, April 8, 1867, Throckmorton to Griffin, May 3, 1867, Throckmorton papers; Circ. 12, April 17, Circ. 16, May 16, Circ. 19, June 1, 1867, Printed Orders, District of Texas; Griffin to AAG, May 7, 8, 1867, Telegrams Received, Fifth Military District records; Sheridan to Grant, May 18, 1867, Johnson papers. 
give the most rigid interpretation to the law. He would "exclude from registration every person about whose right to vote there may be doubt."2 Although Attorney General Stanbery's opinion recommended a more liberal approach, Sheridan received Grant's permission to continue his more restrictive policy until further notice. ${ }^{3}$ Congress vindicated Sheridan's position in the July 19 Reconstruction Act, giving the registrars wide discretionary power in voter registration. 4 The registration boards' subjective power caused a great deal of dissatisfaction among Texans. Numerous letters arrived at Army headquarters accusing the boards of arbicrary action in refusing to register qualified whites. ${ }^{5}$ Texans also believed that the registrars had enrolled Negroes ahead of the regular registration period, had allowed blacks to register without having to stand in line to wait, and had registered freedmen who were under age or could not meet residence requirements. ${ }^{6}$ one disgruntled white related that he had

${ }^{2}$ Sheridan to Grant, April 1, 1867, Grant to Sheridan, April 7, 1867, Grant papers; Sheridan to Grant, April 6, 1867, Johnson papers; Grant to Sheridan, April 21, 1867, Sheridan papers; SO 15, April 10, 1867, Printed Orders, Fifth Military District.

3 James E. Sefton, The United States Army and Reconstruction, 1865-1877 (Baton Rouge, 1967), 128-34.

${ }^{4} \mathrm{U}$. S., Statutes at Large, XV, 14-16.

5 John K. Conally to AAG, December 23, 1867, John M. Claiborne to Hancock, December 23, 1867, I. L. Irion to AAG, December 26, 1867, John W. Hood to Hancock, December 27, 1867, File 57M1868. See also, E. D. Townsend to AAG, October 29, 1867, Letters Received, Fifth Military District records; R. W. Davis to AAG, April 10, 1867, Stephen Southwick to AAG, December 24, 1867, ibid., Civil Affairs.

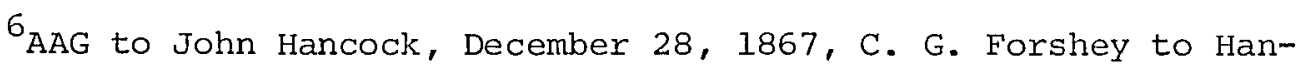
cock, January 5, 1868, File 57M1868; Nat Benton and others to AAG, February 15, 1868, Letters Received, Civil Affairs, Fifth Military District records. 
gone into clarksville to registex, but "a big black nigger, with a nose like a dormant [sic] window, and a pair of lips that looked like he had been sucking a bee gum and got stung in the operation" objected to his enrollment. The rebuffed applicant turned on the black registrar and "took him a clue over the head that would have stunned a beef, but he never winked... ." Undaunted by his failure, the angry white then "gave him twelve inches of solid shoe leather on the shins that brought him to his milk in short order." 7

Many board members would have considered a kick in the shins mild treatment compared to the violence usually reserved for registrars. $^{8}$ In the spring of 1867 there had been many volunteers asking to serve on registration boards. ${ }^{9}$ By the following fall, however, intimidation had caused a large accumulation of resignations at Army headquarters or demands for more pay to offset the hazards of the job. 10

When General Hancock assumed command at New Orleans, he revamped 128.

7J. W. Wilbarger, Indian Depredations in Texas (Austin, 1889),

${ }^{8}$ Capt. L. H. Sawyer to AAG, April 15, 1868, Letters Received, District of Texas records; Griffin to Sheridan, July 15, 1867, Sheridan papers; Flora G. Bowles, "The History of Trinity County" (Unpublished M.A. thesis, University of Texas, Austin, 1928), 55. The Army was forced to provide escorts for the boards, see Circ. 20, June 1, 1867, Printed Crders, District of Texas.

${ }^{9}$ See John C. Brooke to AAG, April 9, 1867, Edward D. Jarrot to AAG, April 29, 1867, John Dix to AAG, April 29, 1867, Letters Received, Civil Affairs, Fifth Military District records; Ange J. de Saint to AAG, May 27, 1867, ibid., District of Texas records.

${ }^{10}$ Dozens of resignations were received by headquarters. E.g. , see James Brown to AAG, September 28, 1867, Letters Received, Civil Affairs, District of Texas records. For the increase in salary request, see Richard Allen to AAG, November 12, 1867, Letters Received, District of Texas records. 
the entire registration system. He admitted there was much doubt as to the intent of the Reconstruction Acts, but he negated Sheridan's guidelines because they were too strict and discriminated unfairly against white applicants. Hereafter, said Hancock, the only rules the boards were to follow were the Reconstruction Acts and the disfranchising clause of the proposed Fourteenth Amendment. ${ }^{11}$

In addition to changing the rules of procedure, Hancock did his best to mitigate possible registration injustice by ordering that certain doubtful cases be registered, but the jealous boards disliked military interference with their decisions. ${ }^{12}$ General Reynolds outwardly appeared to agree with Hancock about registration. He ordered Republicans in each county to do their best to find white registrars and told the boards to confine themselves to asking whether the applicant had ever held a Federal or state office, taken an oath to support the Federal government, or voluntarily engaged in the Rebellion. ${ }^{13}$ In reality, however, Reynolds allowed the boards to pursue their own course with a minimum of interference. 14

${ }^{11} 1_{\text {GO }} 3$, January 11, 1868, Printed Orders, Fifth Military District. Hancock's orders really affected few persons, but again his attitude was important. See Russ, "Radical Disfranchisement in Texas," $45 \mathrm{n} .22$. It is also possible that some of the boards ignored Hancock's orders and registered potential voters only if they favored a new constitution and Negro suffrage. See Dallas Herald, February 1, 1868.

12 SO 57, March 13, 1868, Printed Orders, Fifth Military District records; R. Anthony to AAG, February 19, 1868, Letters Received, Civil Affairs, Fifth Military District records; Charles King to AAG, August 4, 1868, Letters Received, Fifth Military District records.

13 See printed form, AAAG to Nathan Patten, August 29, 1868, Johnson papers. See also, so 51, October 7, 1868, GO 78, April 20, 1869, Go 92, May 12, 1869, Printed Orders, Fifth Military District.

14 There are dozens of letters refusing to overrule registration board rulings. See e. 9. , AAAG to R. E. Borden, April 23, 1869, AAAG 
Because of the yellow fever epidemic and Army command changes, the election scheduled for November was postponed until February 1868; this delay was partly responsible for the Republican victory. ${ }^{15}$ Initially, the Democrats thought that no convention would meet unless a majority of the potential electorate registered and voted. They soon realized, however, that they were mistaken. The crucial factor was whether or not a majority of those registered voted in favor of the convention. The party leaders began to urge their supporters to register and refuse to vote in February. Shortly before the election, it became obvious that the Republicans and their Negro allies had sufficient strength to carry the state even if the Democrats did not vote. The Democratic leaders once again changed their tactics and told their backers to vote against the convention. At the same time, party members were instructed to cast their ballots for conservative candidates who would oppose Negro suffrage. The continual changes in Democratic policy merely confused the voters and resulted in an overwhelming Republican victory. 16

to Valentine Haas, May 5, 1869, Letters Sent, Fifth Military District records; Case of B. Garwood, November 20, 1869, ibid., Civil Affairs.

15 Grant to Mower, September 27, October 1, 1867, Mower to Grant, September 27, 1867, Hancock to Grant, December 7, 1867, Grant to Hancock, December 8, 18, 1867, Grant papers; Hancock to Grant, December 17, 1867, Telegrams Sent, Civil Affairs, Fifth Military District records; so 213, December 18, 1867, Printed Orders, Fifth Military District.

16 Ramsde11, Reconstruction in Texas, 194-99. For the results of the election, see Capt. Daniel o. Drennan to AAG, March 16, 1868, Johnson papers, and so 78, April 13, 1868, Printed Orders, Fifth Military District. See also, Secretary of Civii Affairs to Reynolds, April 16, 1868, Letters Sent, Civil Affairs, Fifth Military District records. Another election was held in April to fill vacancies caused by the deaths of several of the delegates, so 61, April 11, 1868, Printed Orders, District of Texas. 
The convention was scheduled to convene on June 15 , but at Grant's suggestion Buchanan advanced the date to June 1.17 should the convention act quickly, it was possible that the Texas electoral vote could be counted in the Republican column in the up-coming presidential election. But even though the Republicans held all but a dozen of the ninety convention seats, it was immediately obvious that the party was badly split between the men of principle who favored the ab initio doctrine (nullifying all laws passed since 1861), and the more practical politicians who supported Governor Pease's view (validating all laws passed since 1861 not in conflict with the results of the war). Pease's stand had been part of his deal with General Reynolds to gain Army patronage to build up the party's strength. The ab initio men, however, had anxiously awaited a chance to force the party to repudiate Pease's notion, but the governor refused to back down. Under Reynolds' watchful eye, ${ }^{18}$ he forcefully reiterated his concept in his introductory message to the convention. ${ }^{19}$

The Republicans were also split over another issue--whether to divide Texas into two or more states. The size of Texas had been a continual problem in its history. During the debates over the Compromise of 1850 , Congress had entertained a series of resolutions

${ }^{17}$ Grant to Buchanan, May 4, 5, 1868, Buchanan to Grant, May 4, 5, June 3, 1868, Grant papers; So 97, May 5, 1868, Printed Orders, Fifth Military District.

${ }^{18}$ Both Reynolds and Pease were escorted down the aisle to the rostrum. Although Reynolds was offered a seat in the convention, he appears to have attended only Pease's speech. See Journal of the Reconstruction Convention . . 1868, I, 9-10, 32 .

${ }^{19}$ Message to the State Convention, June 3, 1868, Executive Correspondence; Ramsdell, Reconstruction in Texas, 206-11. 
proposing to reduce the state's territory. At the same time Senator William H. Seward of New York sponsored a petition from residents of Brownsville, who asked that the Rio Grande valley be made independent of the rest of Texas to help validate dubious land titles there. Both attempts Eailed. 20

During the secession crisis, the western half of Texas was strongly Unionist and opposed the pro-Confederate eastern section. This difference in public sentiment continued throughout the war and into Reconstruction. "In the interest of the Union," wrote a San Antonio man, "the Republican element must be strengthened. Strategically it is important to shut off the old secession element from the frontier." Both of these objectives could best be accomplished by dividing the state in half, he concluded. Governor Pease, however, refused to sanction the scheme and spoke out against it in his message to the convention. Once again the Republicans split over an important issue; the ab initio faction supported the division of the state and the other side opposed it. 21

Although Republicans disagreed among themselves on ab initio and dividing Texas, all sides concurred in the approach to a third problem--law and order. Lawlessness was rife in the state and the convention established a special committee to find out why. The committee concluded that it was "not difficult to fix the responsibility of this

${ }^{20}$ Ramsdell, Reconstruction in Texas, 212-16; Holman Hamilton, Prologue to Conflict: The Crisis and Compromise of 1850 (New York,

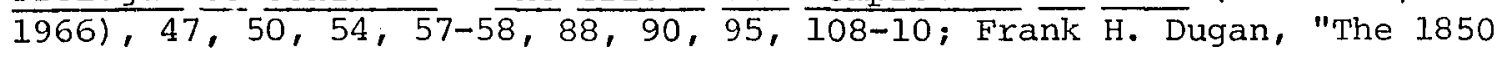
Affair of the Brownsville Separatists," Southwestern Historical quarterly, LVI (1957-58), 270-87.

${ }^{21}$ E. Degener to Pease, October 24, 1867, Pease papers; Message to the State Convention, June 3, 1868, Executive Correspondence. 
increase of crime" on General Hancock and his General Orders No. 40. Special castigation was reserved for General Buchanan because he "turned a deaf ear to the cry of tried and persecuted loyalists." The committee charged Buchanan with the deaths of "hundreds" of Union men, "a responsibility that should load his name with infamy, and hand his very memory to coming years as a curse and an execration." 22 The convention voted an appropriation of $\$ 25,000$ in reward money to assist civil officers in apprehending criminals. It stipulated, however, that none of the money would be paid unless the offenders were tried by military commissions. 23

In August the state Republican party assembled in a private meeting at Austin to work out a party platform. Because the ab initio faction controlled only one-third of the seats, the state Republicans easily adopted Governor Pease's viewpoint as party policy. Their angered opponents withdrew from the party's councils and held their own meeting in which they endorsed the ab initio doctrine. Since the party regulars held the patronage and the constitution still had to be written, however, $\underline{a b}$ initio men returned to the party ranks once more. 24 Shortly after the Republican party conference ended, the state convention adjourned. It had been in session for eighty-five days but had accomplished little constructive work on the constitution. The Republicans argued among themselves instead; the idealogues refused to yield in their insistence that the convention endorse the ab initio

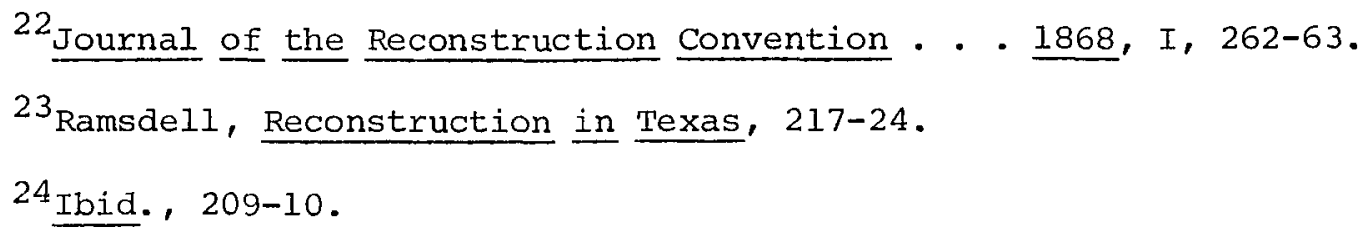


position. The Democrats did everything in their power to prevent either side from achieving a victory. The convention's $\$ 100,000$ expense account was nearly exhausted, and the irritated General Reynolds refused to authorize additional expenditures. 25

In addition to a shortage of funds, the national political scene now assumed an important role in the Reconstruction process in Texas. If the Republican presidential candidate, General Grant, won the 1868 election, Military Reconstruction could be expected to continue in full force and the Texas party would benefit from Federal patronage. Should the Democrats win the presidency and the House of Representatives, Texas might not have to comply too rigorously with the Reconstruction Acts. On July 20 Congress forbade the unreconstructed states of Texas, Mississippi, and Virginia from having their electoral votes counted, but the law did not expressly prohibit those states from holding an election. 26

Because the presidential race promised to be a close one, it was possible that a deadlock might develop in the electoral college. The Texas Democrats decided that their state should participate in the balloting just in case their electoral vote might be counted. State law required the governor to order an election, but Pease refused to act. Rather than directly challenge Pease's authority by having Throckmorton (whom many considered the "rightful" governor) issue the proclamation, the Democratic state executive committee recommended an

\footnotetext{
${ }^{25}$ Journal of the Reconstruction Convention . . 1868, I, 779, $858-59,1 \overline{060}$.

${ }^{26}$ Ramsdell, Reconstruction in Texas, 235-36; U. S., Statutes at Large, XV, 257.
} 
alternate course. All registered voters in each county would informally meet on November 3, appoint an election supervisor, cast their ballots, and send their returns to the committee. Reynolds, however, was taking no chances that Texas would appeax in the Democratic column in any election. He immediately declared that no balloting for presidential electors would take place in any form at any time. 27

Not only was Grant elected in Noveminer, but Reynolds was removed by President Johnson. ${ }^{28}$ Reynolds' replacement was Major General Edward R. S. Canby who had been in charge of the Department of Louisiana after the war. Canby left Louisiana in 1866 and President Johnson used him as a troubleshooter in states with difficult Reconstruction problems. Canby had helped engineer successful constitutional conventions in both North and South Carolina, 29 and in 1868 Johnson hoped to utilize his services in Texas. The President liked Canby because the general exercised good judgment, foresight, and moderation in dealing with southern whites. Rarely did he try to overawe them with a show of excessive strength. Congress also found Canby acceptable because he was insistent about protecting the rights of Negroes and Loyalists. 30

${ }^{27}$ SO 44 , September 29,1868 , Printed Orders, Fifth Military District; Ramsdell, Reconstruction in Texas, 236-37.

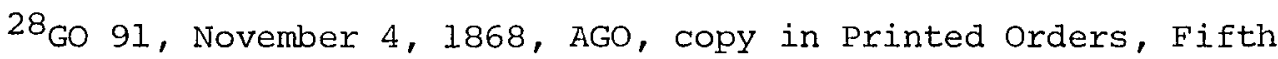
Military District.

${ }^{29}$ For Canby's service in North and South Carolina, see J. G. de Roulhac Hamilton, Reconstruction in North Carolina (New York, 1914), 232, 234-40; Francis B. Sinkins and Robert H. Woody, Reconstruction in South Carolina (Chapel Hill, 1932), 65-67, 107, 109-10, 175. Canby's service record is in Heitman, Historical Register, I, 279;

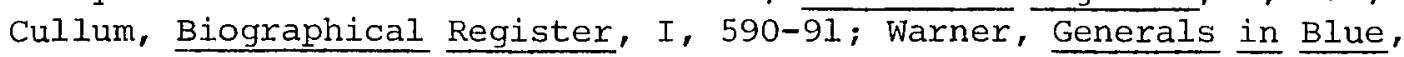
$67-68$.

${ }^{30}$ Max L. Heyman, Jr., Prudent Soldier: A Biography of Major 
Canby's first task was to ensure that the Texas convention wrote a constitution. Then he had to call an election to ratify it and see that the voters chose a new government. Once again, however, the two Republican factions refused to cooperate with each other. Although the ab initio question had died out, the quarrel over dividing Texas into several states persisted. The idealogues, who had supported ab initio, even drew up a constitution for "West Texas" which they hoped to submit to Congress for approval. They had to obtain Texas' permission first, however. The debates over division lasted until late January when the divisionists, led by Edmund J. Davis, the convention president, finally won. The measure was passed only because of doubtful parliamentary measures, which included voting without a quorum. 31

Although the Radical Republicans, as they were becoming known, had their way on the division issue, the Moderate Republicans and the Democrats combined to defeat them on a second matter, the disfranchisement of former Confederates. The Moderates led by A. J. Hamilton and Governor Pease believed that the future of the Texas Republican party depended upon attracting the "thinking element" of the opposition to its ranks. To restrict their participation in politics beyond the officeholding restrictions of the Fourteenth Amendment would alienate this source of votes from the party, which was still a minority in the state. The Radicals, however, refused to compromise, perhaps because they felt that Congress would authorize the proposed state of

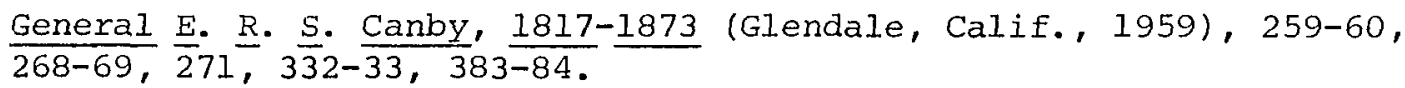

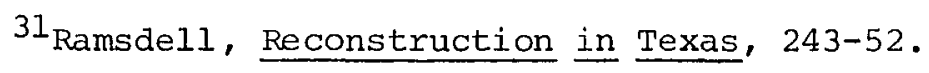


West Texas. If so, there was no need to appeal to the former Confederates who lived primarily in the eastern part of the state. ${ }^{32}$ Because of the serious political in-fighting in the convention, few members were pleased with the new constitution. The Moderates and most Democrats decided to live with the document, but twenty-two Radicals introduced a resolution condemning it. They charged that the constitution failed to declare the laws passed after 1861 null and void, to disfranchise the former Confederates, to require a strict loyalty oath of all officeholders, and to safeguard equal political and civil rights for all persons. The signers asked the voters to refuse to ratify the constitution. ${ }^{33}$

Canby did his best to avoid interfering with the convention's business. But when the body refused to provide for the preservation of the recoxds because of political bickering, he felt obliged to intervene. The general warned the convention that he would print the records if they did not. The convention was so divided by this time that each faction adjourned separately. A. J. Hamilton contacted Canby and asked him to supervise the preparation of the convention's records. Hamilton had forcibly confiscated the documents from an assistant secretary and Davis supporter, A. T. Bennett. Canby received the papers and ordered a three-man committee (M. C. Hamilton, A. J.'s brother and a Radical; J. W. Thomas, a Moderate; and Major C. R. Layton 
of his staff) to supervise their preparation. 34

Having provided for the preservation of the convention records, Canby then ordered the constitution submitted to the people in July. He felt the long delay was necessary because all of the registrars had been discharged after the last election and they still held the registration books. He feared that to locate them would take two or three months. The general also believed a semblance of law and order could be restored to Texas by summer provided he could find civil officers for the thirty counties that had none. ${ }^{35}$ Canby moved immediately to fill the vacant civil offices and appointed about 200 men. Unlike his predecessors, he found it necessary to replace only a few officials, sixteen in all. 36

While Canby was straightening out civil affairs in Texas, both Republican factions sent committees to Washington to confer with Grant and Congress and convince the national government that they represented the true party. The Radicals failed to persuade Congress that Texas should be divided in half. They were further disappointed that Congress was disposed to accept the new constitution and end

\footnotetext{
${ }^{34}$ Canby to Davis, February 5, 1869, Davis to Canby, February 5, 1869, ibid., 527, 529; So 30, February 7, 1869, Printed Orders, Fifth Military District; Canby to Rawlins, February 11, 1869, House Executive Documents, 40th Cong., 3rd Sess., No. 97, 2-3; Ramsdell, Reconstruction in Texas, 258-60; Heyman, Prudent Soldier, 337-38.

${ }^{35}$ Canby to Rawlins, February 4, 1869, Letters Sent, Fifth Military District records.

${ }^{36}$ Heyman, Prudent Soldier, 238-39. Canby issued sixty orders making appointments. Typical examples are so 15, January 19, so 26 , February 3, So 40, February 18, so 75, March 31, 1869, Printed Orders, Fifth Military District. Canby is listed as making 203 appointments in "Civil Officers, Texas," and 179 in "Election Register, 1866-1870." His removals are in "Civil Officers, Texas."
} 
Reconstruction in the state. The President-elect, however, remained noncommittal and informed the two committees that Federal patronage would be divided equally between them. A. J. Hamilton and J. L. Haynes, who led the Moderate delegation, were introduced to Grant by an old mutual friend, General Reynolds. As Grant's old classmate, and now his advisor on the Texas situation, Reynolds secured the majority of the Federal appointments for the Moderates. 37

In Washington the Moderates managed to obtain another favor from Grant. Most Texas Republicans felt that Reynolis had been treated unfairly when he was removed from the command of the Fifth Military District by President Johnson. They had no real quarrel with Canby's policies, but he was much too judicious and non-partisan to suit party members. They needed someone "reliable" should an "emergency" situation develop as the Reconstruction process was ended. 38

On March 5, the day after Grant was inaugurated, he reassigned Reynolds to the Fifth Military District replacing Canby. ${ }^{39}$ Reynolds arrived in Texas on April 8, and immediately set to work to insure a Republican victory in the upcoming election. He first faced a problem;

37 Haynes to W. W. Mills, April 9, 1869, Hamilton to Mills, June I, 1869, W. W. Mills papers, Archives, University of Texas.

${ }^{38}$ See C. B. Sabin to Pease, November 14, 1868, Pease papers. There were continued references to "the faithful and impartial manner" in which Reynolds acted to enforce the Reconstruction laws at the state convention. One Republican even tried to amend the convention's welcome to Canby by prefacing it with the statement, "While regretting the removal of Bvt. Maj. Gen. Reynolds and whereas.. . ." Journal of the Reconstruction Convention . . 1868, II, 40-41, 171.-73.

${ }^{39}$ GO 10, March 5, 1869, AGO, copy in Printed Orders, Fifth Military District; GO 71, April 8, GO 72, April 8, 1869, ibid. Canby was sent to Virginia, Heyman, Prudent Soldier, 339. 
he had to decide which party faction to support. It was becoming more and more obvious that there would be two Republican tickets in the election. The Moderates, or Republican ticket, was headed by their gubernatorial nominee, A. J. Hamilton; the Radical slate was led by Edmund J. Davis who had presided over the convention. 40

Hamilton, the practical politician, sought to expand the base of the Moderates by attracting Democratic support. His stand in the convention against disfranchisement had mitigated much of the hate and hostility his Unionism had secured for him. "It is deeply gratifying to witness everywhere I go," he wrote, "so complete a change of feelings, sentiments, and purposes on the part of those who have been in hostility to the Government. "4l

The Davis party accused Hamilton of selling out to the Rebels. Although the Davis committee had failed to secure Grant's support in February, Davis did make a favorable impression on many Republicans in Congress as well as on Grant's cabinet. Hamilton, on the other hand, had offended some Republicans. Attorney General E. R. Hoar once had a "fierce interview" with Hamilton in which he called the Texan a "copperhead." The outraged governor leaped up, shook his fist, and shouted, "G-d d--n you, or any man, who impugns my political motives!" Hamilton knew there was only one way to win in an honest election in Texas--he would have to have a large number of Democratic votes. 42

40 Hamilton to Mills, June 1, 1869, Mills papers.

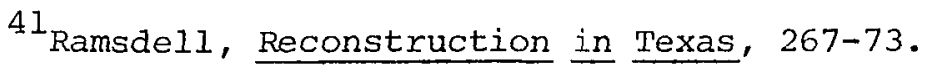

42 William H. Fleming to Pease, April 20, July 8, 1869, Pease papers; clipping enclosed in letter of Michael Hahn to Mrs. W. W. Mills, May 3, 1869, Mills papers. 
General Reynolds, however, knew that elections in Texas might not be honestly conducted. Ready to use his control of the patronage and military force to achieve a victory for one side, he felt that his services entitled him to some reward. Upon his arrival in April, Reynolds indicated to the Moderates that they should formally split up the party and "organize on the basis of new men," including himself. The Moderates responded favorably to his proposal knowing that Reynolds "might not despise a seat in the U. S. Senate" in exchange. "I think he should be industriously manipulated," wrote A. P. McCormick to James H. Bell, "and you and Haynes and Governor Pease will have to do this for Gov. Hamilton wont do that kind of work." 43

While the Moderate leadership was industriously manipulating Reynolds, the general was diligently juggling the registration procedure to insure a large Democratic (Moderate) vote. Reynolds' dedication led the Davis group to attempt his removal but they failed to shake Grant's confidence in him. ${ }^{44}$ Rumors abounded in Texas and Washington about Reynolds' deal with the Moderates. No one was sure of the terms but a senatorial seat was frequently mentioned. In due time, A. J. Hamilton learned the truth and was so incensed at the negotiations carried on behind his back that he publicly repudiated the whole agreement. Hamilton's honesty and desire to appeal to the Democrats put him at a great disadvantage. ${ }^{45}$

$43 \mathrm{~J}$. G. Tracy to Pease, April 8, 1869, A. P. McCormick to Pease, April 28, 1869, Pease papers; McCormick to [James H. Be11], April 28, 1869, Bell papers.

${ }^{44}$ Haynes to Pease, June 15, 1869, Pease papers.

45 Ramsde11, Reconstruction in Texas, 274-75. To keep Democratic support, Hamilton had to be extremely careful in his relations 
Rebuffed by Hamilton, Reynolds calmly turned to the Radicals and made the usual arrangement. For the promised senatorial seat, Reynolds offered the Radicals state patronage and time to organize their party on local levels, Federal patronage and influence with the Grant administration, and control of the state election machinery. The first thing Reynolds did was postpone the scheduled July election until further notice. Time was on the Radicals' side; the longer they waited, the more tenuous the ties between Hamilton and the Democrats became. Time also meant that Davis and Reynolds would be able to replace those local officeholders who were in the Hamilton camp. 46 Governor Pease had largely controlled appointments for local offices for nearly two years and Pease was a Hamilton supporter. During the short time Reynolds had been with the Moderates, he had helped Pease replace those Davis men in office with Moderates. Reynolds now reversed the process and began to remove the Hamilton men and replace them with Radicals. They were aided by Hamilton's earlier insistence that certain reconstructed Confederates be used and a new law passed by Congress which declared that all officeholders had to

with the military. To appear too friendly might cost him the election. The Democrats already had a ticket in the field supported by those who felt a vote for either Hamilton or Davis was a Radical vote. The more Democrats that voted for their party, the more Davis stood to win. For anti-Hamilton Democrats, see Texas News (Bonham), January 9, February 13, March 6, 20, 1869; Brownsville Daily Ranchero, January 15, 1870.

${ }^{46}$ Ramsdel1, Reconstruction in Texas, 274-75. The need for time to organize the Radical party on the grass roots level is emphasized in M. C. Hamilton and others to AAG, November 8, 1869, and E. J. Davis to AAG, November 10, 1869, Letters Received, Civil Affairs, Firth Military District records. Reynolds originally asked Grant to schedule the election in late May, which would have helped Hamilton. See Reynolds to AGO, May 20, 1869, Letters sent, ibid. 
take the "ironclad oath." The Radicals estimated they would need at least half of the 3,000 Pease appointees removed. ${ }^{47}$ Between January 1869 and January 1870 the Army issued 300 orders in Texas of which 196 converned removals and appointments. Two-thirds of these decrees were Reynolds' and the rest were Canby's. By insisting on the "ironclad oath," Reynolds was able to fill nearly 2,000 political openings in local government and most of them were Radicals. 48

Reynolds' influence was also decisive in securing Federal patronage and influence with the Grant administration. Reynolds was Grant's ultimate source of knowledge on all that went on in Texas. Because the Republican party was split, he received two accounts of every incident. Naturally the President turned to his old West Point classmate for the "truth" and advice on all appointments. In the summer of 1869 Reynolds recommended Radicals just as he had suggested Moderates before. Appropriately, the first Moderate to lose office was the customs collector at El Paso, W. W. Mills, Hamilton's son-inlaw. When he was queried about the change in policy, Reynolds told the President that he had tried to use the best men of both Republican factions but found he could not. Hamilton was allied with the Demo-

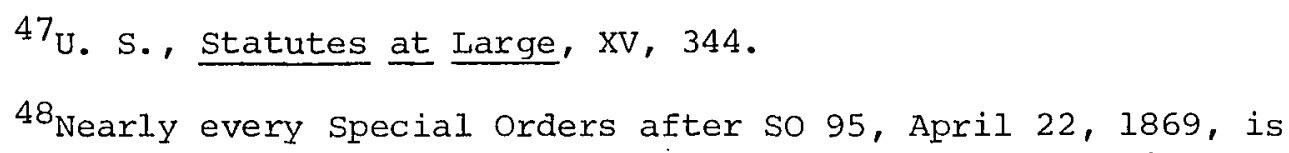
filled with appointments and removals. See Printed orders, Fifth Military District, 1869 series. See also, "Civil Officers, Texas," which lists 2,051 appointments and "Election Register, 1866-70," which lists 1,667 appointments. The oath requirement allowed Reynolds to have to make only 139 removals. See "Civil Officers, Texas." For the effect of Reynolds' manipulations on the local level, see Reese, "History of Hill County," 136, and Marion Merseburger, "A Political History of Houston, Texas, During the Reconstruction Period As Recorded by the Press, 1868-1873" (Unpublished M.A. thesis, Rice Institute of Technology, Houston, 1950), 44-45, 47-48, 78, 97. 
crats, said Reynolds, and his victory "will put the state in the hands of the very men who, during the entire period of the rebellion, have exerted every nerve to destroy the Union, and who have uniformly opposed the reconstruction laws . . . ."49

Reynolds' use of the Federal patronage and his letter to Grant brought about an unexpected dividend--Governor Pease's resignation. Pease had never liked being governor ${ }^{50}$ and had reluctantly assumed the job "to aid in carrying out the laws of Congress for equal rights for all." He felt the only way this could be achieved was to ratify the new constitution and elect Hamilton. Pease disliked the way in which "the influence and patronage of the Military Commander of this state, and of the Administration at Washington" were being used "in behalf of those Republicans who have exerted themselves to delay and defeat the reconstruction of the state... ." He refused to have his name connected with Reynolds' actions and resigned. 51

Shortly after Pease's resignation, Reynolds grew overly cautious. He refused to appoint a new provisional governor and some Radicals feared he was flirting with the idea of putting a Hamilton man in office. "Reynolds is an honest amiable man," declared one Radical, "but he is no more fit for a Military commander in Texas than a child." Morgan Hamilton, A. J.'s brother and a Davis supporter, quelled these

${ }^{49}$ C. Caldwel1 to Pease, July 17, 1869, Pease papers; Reynolds to Grant, September 4, 1869, in American Annual Cyclopaedia (1869), 674-75. See also, Ramsdell, Reconstruction in Texas, 276-77.

50 Pease to Carrie, August 3, 1867, March 21, 1868, Pease papers.

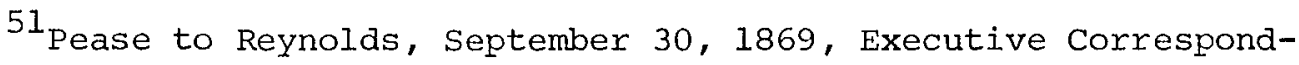
ence. For Reynolds' acceptance of Pease's resignation, see so 232, October 2, 1869, Printed Orders, Fifth Military District. 
worries. Leave Reynolds alone, he said. The general was already frightened to death over what he had done and he would not move again without a direct order from Grant. 52

With Reynolds now acting as military commander and governor, the Radicals controlled all of the election machinery in the state. Before his adherence to their cause, the Radicals had had only one advantage over the Moderates. Because Davis presided over the convention, he saw to it that the election returns for each district would be sent to "safe" collection points, and counted. 53 Now Davis and Reynolds would show Hamilton that victory was not necessarily guaranteed to whoever had the most votes, but to whoever counted them. At Reynolds' suggestion, Grant ordered the Texas election to be held at the beginning of December, six months later than originally planned. The Army stationed ten men near each polling spot. The troops were not to appear at the polls, however, unless a breach of the peace occurred. 54 The election was remarkably quiet and without incident. The constitution was overwhelmingly approved, but because a large number of whites stayed home, Hamilton's vote was much smaller than expected. Numberous cases of fraud were reported ${ }^{55}$ and both the Moderates and

52 George C. Rives to J. P. Newcomb, September 7, October 5, 1869, M. C. Hamilton to Newcomb, October 16, December 25, 1869, J. P. Newcomb papers, Archives, University of Texas.

53 Haynes to Mills, April 9, 1869, Mills papers.

54 GO 174, October 1, GO 185, October 18, 1869, Printed Orders, Fifth Military District. Congress had delegated to Grant the authority to call elections on April 10, 1869. U. S., Statutes at Large, XVI, 40-41.

${ }^{55}$ See, e.g.., James E. Wood to AAG, December 31, 1869, L. P. Harris to AAG, December 31, 1869, E. Degener to AAG, February 7, 1870, Letters Received, Fifth Military District records; Secretary of Civil 
Democrats demanded that Reynolds investigate election irregularities, especially in Navarro and Milam counties. Reynolds, however, simply refused to count the vote in these counties and declared Davis elected by about 800 votes. $^{56}$ In January 1870 the general appointed all those elected to serve provisionally until Congress accepted the new constitution and government. 57

Reynolds' services to the Radicals were not yet completed. In December, M. C. Hamilton wrote Reynolds and complained that the oath of office in the new Texas constitution was too lenient and easily falsified. He asked Reynolds to require that the oath be administered by a Federal official and that the penalties for perjury be attached to it.. Reynolds went further than Hamilton asked; on February 5, 1870, the general ordered all members-elect of the state legislature to subscxibe to the "ironclad oath." Reynolds reasoned that since these mer were serving provisionally until Congress approved of the new constitution and government, they were technically Federal rather than state officials. 58

Affairs to Thomas H. Brenard, January 5, 1870, Letters Sent, ibid. See also, Ramsdell, Reconstruction in Texas, 284.

${ }^{56}$ For the figures, see GO 18, February 1, GO 19, February 1, Gu 73, April 16, 1870, Printed Orders, Fifth Military District; Texas Almanac (1870), 194-97.

${ }^{57}$ So 6, January 8, Go 5, January 11, 1870, Printed Orders, Fifth Military District. Fifty-nine of eighty-four Special orders contain appointments to offices. Local commanders informed the appointees of their election and appointment. See Secretary of Civil Affairs to CO, Post of Waco, January 14, 1870, Letters Sent, Civil Affairs, Fifth Military District records. Local commanders and politicians asked Reynolds to appoint those elected. CO, Ft. Brown to AAG, January 31, 1870, J. B. Ferguson and others to AAG, February 18, 1870, Letters Received, ibid.

58 M. C. Hamilton and 3 others to Reynolds, December 20, 1869, 
After requiring the "ironclad oath," Reynolds appointed a board of military officers to hear disputes over eligibility questions. The board would rule on a candidate's ability to take the oath, but such a ruling was not to be considered as a determination for contested legislative seats. Once a candidate was declared eligible by the Army, he had to be approved by the respective house of the legislature before he could take his seat. Naturally, with their Democratic antecedents, Hamilton candidates would have more difficulty in taking the "ironclad oath. " 59

In February the provisional legislature met in Austin. It quickly ratified the Fourteenth and Fifteenth amendments and proceeded to the next order of business, the election of United States senators. Reynolds was among the leading contenders but unexpected opposition developed within the Radical party. The Democratic newspapers also castigated him for becoming a candidate before a body which he had largely manipulated into office. On February 16 the general announced he would not seek any civil office and the legislature elected Morgan Hamilton and J. W. Flanagan. 60

With the seating of the Davis legislature and the approval of the Fourteenth and Fifteenth amendments, Texas had complied fully with the Reconstruction Acts. On March 31 the jurisdiction of the Fifth

House Executive Documents, 4lst Cong., 2nd Sess., No. 60, 1-2; GO 21, February 5, 1870, Printed Orders, Fifth Military District; Russ, "Radical Disfranchisement in Texas," 51.

${ }^{59}$ See e.g., GO 24, February 9, GO 25, February 9, GO 28, February 14, $\overline{\mathrm{G} O} 30$, February 19, 1870, Printed Orders, Fifth Military District.

${ }^{60}$ Ramsdel1, Reconstruction in Texas, $290,307$. 
Military District was terminated and the state became the Military

Department of Texas commanded by Reynolds. Civil government was fully restored on April 16, 1870, and Texas was back in the Union nine years after she had left it. 61

${ }^{61}$ The last Special Orders is appropriately a list of military appointments, see SO 84, April 16, 1870. For the termination of military rule, GO 35, March 31, 1870, AGO, copy in Printed Orders, Fifth Military District; GO 74, April 16, 1870, ibid. The Office of Civil Affairs did not complete its work (paying election registrars and supervisors) until August 31, 1870. 
VIII. "OUTSIDE THE DUTY OF MY PROFESSION"

Brigadier General Samuel D. Sturgis had a reputation for saying what he thought in a very blunt manner. A tough old regular, he was best known for his classic Civil War statement about Major General John Pope, "I don't care for John Pope one pinch of owl dung!" Now Sturgis was on Reconstruction duty in Texas and he hated the nonmilitary aspects of his job as much as he had disliked Pope. When garrison commanders were instructed to submit monthly reports on civil affairs, Sturgis obstinately grumbled that the whole matter was "outside the duty of my profession," and refused to cooperate. ${ }^{1}$

Sturgis and other officers who supervised the Texas government during Reconstruction had to handle many varying and complex problems that their west Point training had not prepared them for. In addition to state politics, the Army's concern extended into the fields of economics, property seizures, taxes, newspaper censorship, mail service, and regulations concerning sanitation. All of this forced the Army to solve a massive logistical problem in its attempts to supply its troops who were stationed all over the state.

The Army played an important role in regulating and stimulating the state's economy after the Civil War. A typical example was the cattle industry. Raising livestock had been an important part of the

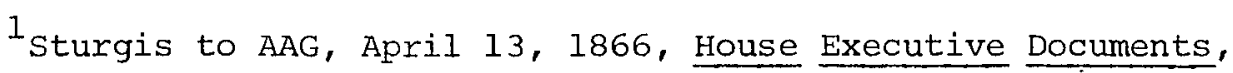
40 th Cong., 2nd Sess., No. 57, 123. 
Texas economy before the war. Herds were shipped eastward to New Orleans and up the Mississippi River to northern markets. The war ended this trade, and although confederate armies needed large herds of beef, the Vicksburg campaign effectively separated Texas from the rest of the South. The result was that the untended herds grew wild and multiplied. The triangle formed by the Gulf, the Rio Grande, and a line running east and west south of San Antonio, held an estimated five million head of stock in $1865 .^{2}$

On the overstocked Texas ranges, the price of beef was too low to make rounding up the cattle worthwhile. But in the North the price ran close to fifty dollars per head. The eager cattlemen could gather a herd in spring, run it north to a Kansas railhead, and return rich men. The entire North suffered from a lack of meat after the war. In addition, other markets existed in the former Confederacy and on the plains where the Army and railroads offered lucrative contracts to suppliers. The profitable trade was offset by the outlaws who infested the trails to the north, and it became part of the Army's job to protect these trail drives. ${ }^{3}$

To regulate and stabilize the cattle industry, the Army issued General Orders No. 17, which stated that all persons buying or selling

2 Walter Prescott Webb, The Great Plains (Boston, 1931), 207-15; Daniel Evander McArthur, "The Cattle Industry in Texas, 1590-1918" (Unpublished M.A. thesis, University of Texas, Austin, 1918), 94-96; Frank E. Vandiver, "Texas and the Confederate Army's Meat Problem," Southwestern Historical Quarterly, XLVII (1943-44), 225-33; Alonzo Bettis Cox, "The Economic History of Texas During the Period of Reconstruction" (Unpublished M.A. thesis, University of Texas, Austin, 1914), 50-74; John Evetts Haley, "A Survey of Texas Cattle Drives to the North, 1866-1895" (Unpublished M.A. thesis, University of Texas, Austin, 1926), 106-108.

3Haley, "A Survey of Texas Cattle Drives," 109-11, 127. 
beef had to deal in branded animals. The fine of twenty-five dollars for this offense was to be shared by the informer and the convicting jury. Local authorities required dealers in hides to report who had sold them their wares. If civil courts proved lax in their enforcement of the law, military commissions could be set up to handle offenders. In a later order, the Army established inspection stations along the cattle trails to eliminate rustling on the way to market. Inspection, however, was made only upon request, and the complainant had to pay for all loss of time if the herd passed the investigation. 4 Although the Army regulated the cattle trade, it generally did not interfexe in the industrial development of Texas. There was very little industry in the state before, during, or after the war even though the Confederate government had passed a law granting 320 acres of 1 and for every $\$ 1,000$ invested in manufacturing. Of the major cities in Texas, Galveston and Jefferson both declined after the Civil War. Galveston had a harbor no deeper than twelve feet but it was the deepest in the state. The port was susceptible to yellow fever and hurricanes, and the business community stifled its growth by charging excessive cargo rates and ignoring railroad development. Jefferson also neglected the advancing rail system, placing its money in steamboats. The result was that the economic centers of the state became the inland towns of Houston, San Antonio, and Austin, which did back the railroad networks. Washington ordered Sheridan to protect the rights of the stockholders of the Buffalo Bayou, Brazos and Colorado Railway Company and to allow them to operate the line privately unless

${ }^{4}$ GO 17, February 25, 1869, GO 108, June 7, 1869, Printed Orders, Fifth Military District; Bvt. Brig. Gen. H. B. Clitz to AAG, May 2l, 1869, Letters Received, Fifth Military District records. 
it failed to provide adequate service. The Army built another line in the Rio Grande Valley but it was soon sold at public auction. The Army's attitude was that Texas law was adequate on all matters pertaining to taxiffs, freight charges, and railway company rights within the state. Officers were cautioned not to interfere in these matters. 5 While cattle-raising and industry expanded after the Civil War, Texas remained primarily a cotton-producing state. Because of the effects of the war and the freeing of the slaves, it was not until 1873 that the farmers even matched the 1860 crop. Plantations were broken up and to some limited extent the white planters, especially in northern Texas, diversified their production by shifting to corn and wheat. The Army was very interested in cotton in 1865, because much of the crop had been sold or pledged to Confederate agents and thus became public property subject to confiscation. United states treasury agents flooded the state searching for "public property." 6 The treasury agent system lent itself to corruption. Men passed themselves off as agents and robbed farmers of their cotton. Naturally Texans came to suspect all men who claimed to be agents. Sheridan issued an order to facilitate the movement of private cotton

${ }^{5}$ Cox, "Economic History of Texas," 137; Nunn, Texas Under the Carpetbaggers, 239-40; Bernard Axlerod, "Galveston: Denver's DeepWater Port," Southwestern Historical Quarterly, LXX (1966-67), 219-20; Ruby Lee Garner, "Galveston During the Civil War" (Unpublished M.A. thesis, University of Texas, Austin, 1927), 21-22; Kenneth W. Wheeler, To Wear a City's Crown: The Beginnings of Urban Growth in Texas,

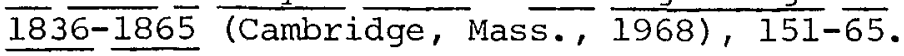

${ }^{6}$ Cox, "Economic History of Texas," 2, 5, 13, 136-37, 142; Berta Lowman, "The Cotton Industry in Texas During the Reconstruction Period" (Unpublished M.A. thesis, University of Texas, Austin, 1927), $8-10$. 
out of Texas and to make local officers assist legitimate treasury men in the collection of public goods. At the same time, the general warned his soldiers that they were "not authorized to employ military authority in any way that might embarrass the public service or impede the shipment of cotton in private hands." Nonetheless, when Thomas Affleck, a Brenham planter, tried to ship his crop the local commander confiscated two bales of it as public property before it was allowed to pass. 7

Other complaints against Army personnel and treasury agents arrived in Austin. A Prarie Lea man asserted that his brother had brought home a two-horse wagon that had been given to him while he was in the Confederate Army. A nearby Yankee provost marshal seized the vehicle as public property after the man bought it from his brother. The Waco Manufacturing Company wrote a letter to Governor A. J. Hamilton testifying that treasury agents had confiscated the firm's machinery as public property. Other establishments found that pre-war debts were now being collected with incerest. Turner and Daggett, a dry goods store in Fort Worth, had paid the Confederate government $\$ 30,000$ which had supposedly cancelled its debt of a like sum to a New York dealer. But in 1865 Turner and Daggett were re-assessed the debt by their New York creditors who were backed by the Federal government by means of the Army. ${ }^{8}$

At key towns throughout Texas, public property was collected by

7Lowman, "The Cotton Industry," 12, 15-16; GO 3, June 1, 1865, Printed Orders, Military Division of the Southwest; Grant to Sheridan, May 28, November 2, 1865, Grant papers.

8 Leo Hardeman to A. J. Hamilton, November 5, 1865, Thomas Harrison to Hamilton, January 22, 1866, Governor's papers (Hamilton); Sergeant, "Early History of Tarrant County," 150. 
surrendering Confederate authorities and turned over to Governor Hamilton's new civil officials. When the Yankees finally arrived, they began to repossess the goods from Hamilton's people. To prevent confusion and breakdown in local government, Governor Hamilton asked General Wright not to enforce the order to collect public property if his own provisional government officials had already assumed responsibility for it. 9

This confiscation of property led to some bitterness. Lieutenant Colonel Thomas M. Browne, Seventh Indiana Cavalry, commissioned Judge A. M. Bryant to accept and collect all public property in Grayson county and to appoint sub-agents to assist him. One of these subagents, George P. Boyd, repossessed a revolver with "U. S." markings from an ex-Rebel soldier. The former confederate went to a local justice of the peace who issued an injunction against Boyd and ordered the weapon returned. When Boyd informed Judge Bryant of this, the latter ordered all of the parties to appear in his court and returned the six-shooter to Boyd. The ex-Confederate then proceeded to a higher court where a grand jury indicted Bryant and Boyd for false arrest. A suit for $\$ 10,000$ damages was also filed against them. Bryant wrote the Army a hasty letter asking for help. He dismissed the indictment of the local grand jury as "mob law" and said the petit jury would be filled with "traitors." He stated that both he and Boyd were loyal Union men while the other defendants were once in the Confederate army. ${ }^{10}$ 
Not only did the Army supervise the confiscation of public property, but it was also concerned with the collection of state and local taxes. The state treasury was empty when the occupying forces arrived in 1865 because brigands had broken in and taken the remaining $\$ 5,000$ in specie on June 11,1865 . The state ledger was not kept between June 8 and October 13 that year, a dramatic illustration of the inoperable condition of state government. ${ }^{11}$

The Army was instrumental in forcing the payment of overdue Federal taxes and cancelling unpaid Confederate Ievies. ${ }^{12}$ when the Reconstruction Acts were passed, there was some confusion as to whether or not state taxes could be collected. Many citizens believed that the eradication of state boundaries and government would also cancel state taxes. General Griffin quickly issued Circular No. 15, May 13, 1867, which informed Texans that their tax obligations to the state would

${ }^{11}$ See Edmund Thornton Miller, A Financial History of Texas (Austin, 1916), 155. Also of interest are his articles, "The state Finances of Texas During the Civil War," The Quarterly of the Texas State Historical Association, XIV (1910-11), 1-19; "The State Finances of Texas During Reconstruction," ibid., 87-109; "Repudiation of the State Debt in Texas Since 1861," Southwestern Historical Quarterly, XVI (1912-13), 169-83. Miller finds there was no corruption or financial mismanagement in the Texas treasury during Military Reconstruction, and not an excessive amount during the $\mathrm{E}$. J. Davis regime that followed, although the Davis period was the worst until that time. Miller admits that many attempts were made to fill friendly pockets with state funds, but points out that Governor Davis and his state comptroller refused to cooperate. When compared with the nation at large or other southern states, Reconstruction spending in Texas does noi appear to be excessive. The larger expenditures of the Davis administration are part of a new philosophy of government that provides for more public services, particularly education. Nunn, Texas Under the Carpetbaggers, 174, 240, 243, and Bancroft, History of the North Mexican States and Texas, II, 503-504, both fail to make this point clearly.

12 Brownsville Daily Ranchero, June 13, 1867; Circ. 17, May 25, 1867, and so 94, July 11, 1867, House Executive Documents, 40th Cong., 2nd Sess., No. 342, 203, 207-208. 
stand as before. A later order, however, cancelled any penalty charges for late tax payments. ${ }^{13}$ Throughout Military Reconstruction the Army regulated the taxing policies of state and local governments by setting rates, approving levies, and negating taxes considered excessive or unfair. The Army also conducted audits of accounts to insure that monies went into the correct funds and were not corrupted. When necessary, the military provided escorts for tax collectors who were unpopular men and hence fearful for their lives. ${ }^{14}$

The military faced numerous miscellaneous tasks that were not envisioned in the scope of the Reconstruction Acts. They had to act as advisors in municipal government ${ }^{15}$ and were involved with such matters as incorporating towns. ${ }^{16}$ In a typical case, General Reynolds received two petitions; the first asked that a county seat be removed to a new town, while the other begged that it be allowed to remain where it was. Reynolds tried to avoid the issue by refusing to consider either request. He thus made a decision by default in favor of the second petition--a matter that he had conveniently failed to consider. ${ }^{17}$

${ }^{13}$ Circ. 15, May 13, 1867, so 192, October 20, 1867, so 200, November 8, 1867, Printed Orders, District of Texas.

${ }^{14}$ SO 3, January 4, 1869, Civil Affairs, GO 41, March 25, 1869, So 17, January 22, 1870, ibid.; R. W. Lane to AAG, May 26, 1868, Letters Received, District of Texas records.

15 James Masterson to AAG, December 18, 1867, Letters Received, Civil Affairs, Fifth Military District records.

${ }^{16}$ SO 29, February 7, so 43, February 24, 1870, Printed orders, Fifth Military District.

${ }^{17}$ Secretary of Civil Affairs to Judge J. S. Goodrich, July 31, 1869, Letters Sent, Civil Affairs, Fifth Military District records. 
Even stranger requests were made of the general. A Fort Worth resident asked that the military intervene and evict squatters on his land because there was "no telling when there will be any Court held in the Denton district. . . " ${ }^{18}$ Another man asked Reynolds to decide who owned all of the rails, timber, and property deposited on his land by a flash flood. The exasperated general decreed that everything belonged to the man whose property they lodged on unless the owner laid claim to them. If the contending parties could not reach an agreement, they could resort to state courts. ${ }^{19}$ A letter from weatherford asked the Army to provide more and better mail service; so Reynolds ordered all males between seventeen and fifty to report to the county courts to repair the public roads which were in an abysmal state. ${ }^{20}$ There was also an order issued to the post commandant at waco to enforce the ordinance on the removal of hogs from the city streets until the law had been ruled on by the state supreme court. 21

Besides handling the more mundane tasks of government, the Army also involved itself with newspaper censorship. The majority of the state's newspapers were openly "disloyal" in their editorial comments. Except in the larger towns like Galveston, Houston, Austin, and San Antonio, few Republican sheets existed. 22 The Brownsville Daily

18 A. G. Walker to AAG, March 7, 1870, Letters Received, ibid. ${ }^{19}$ GO 128, July 10, 1869, Printed Orders, Fifth Military District. ${ }^{20}$ GO 132, July 17, 1869, ibid.; D. O. Norton to AAG, March 3, 1868, Letters Received, Civil Affairs, Fifth Military District records.

21 Assistant Secretary of Civil Affairs to CO, Post of Waco, September 27, 1869, Letters Sent, ibid.

22 The Army did grant printing contracts to local editors to help them stay in business. E.. $\underline{\text {.. }}$, Secretary of Civil Affairs to M. P. 
Ranchero was a rabidly anti-Negro, pro-Democratic organ that daily lambasted the black soldiers in the Rio Grande Valley. Sheridan received adverse reports that the Ranchero used the "basest language" when referring to Federal authority and openly supported Maximilian in Mexico. The Negro soldiers stationed near the city had to be closely watched by their officers to keep them from rioting and destroying the newspaper plant. Such an incident would only have helped the ex-Confederates. The Ranchero and other such papers in the South prompted the War Department to ask commanders to keep a close check on editorial policy. The district commanders required Texas editors to send a copy of each issue to Galveston where it was perused for disloyal articles. By August 1866 Congress considered Federal control strong enough that this order was cancelled. 23

The repeal of the regular newspaper check, however, did not free the editors from the Army's yoke. An offensive article was a sure way for a publisher to sell his product. If he were arrested, he became an instant martyr. Thus, in Brenham the editor of the Southern Banner, a man named McGary, took a great deal of pleasure in criticizing the Freedmen's Bureau and harassing the local troop contingent. The Bureau arrested and fined McGary but he refused to pay and was ultimately released. After he had made fun of the new Negro school, the Freedmen's Bureau again had him arrested, tried before a military

Barrett, February 16, 1870, Letters Sent, Civil Affairs, Fifth Military District records.

${ }^{23}$ Sheridan to Wright, November 28, 1865, Sheridan papers; Sheridan to Grant, January 22, 1866, Grant papers; GO 11, March 9, GO 26, August 2, 1866, Printed Orders, District of Texas. 
court, and fined $\$ 200$. The incident merely served to dramatize what McGary had been saying all along; the Army and the Bureau were despotic and ought to be opposed by "right-thinking" citizens. A short time later, townspeople and soldiers had an argument which resulted in the burning of a substantial part of the business district. ${ }^{24}$

A similar incident occurred at Jefferson. Two freedmen and a white Radical named George $w$. Smith were arrested by civil authorities on charges that were obviously false. They appealed to the military for protection, and the Army succeeded in having them transferred to its stockade. That night, however, an armed mob of one hundred men disguised in $\mathrm{Ku}$ KIux Klan regalia forced the stockade entrance and murdered all three of the accused. The military cracked down and arrested thirty-five suspects who were held without the right of habeas corpus. In response, the newspaper editor, R. W. Loughery, wrote an impassioned editorial denouncing military rule as arbitrary and despotic and sent it to northern newspapers for reprinting. In response to an inquiry from William T. Sherman, the commanding general of the Army, General Reynolds published a lengthy order explaining the whole problem. Continued outbursts by Loughery resulted in his arrest two months later and, like McGary, he became an instant hero. 25 Another problem that faced the Army in Texas was disease.

${ }^{24}$ Capt. A. S. Craig to AAG, April 14, 16, August 21, 23, 1866, Letters Received, Texas Freedmen's Bureau records, R.G. 105, National Archives; AAG to Craig, August 30, 1866, Bvt. Brig. Gen. J. B. Kiddoo to Throckmorton, September 3, 13, 1866, Letters Sent, ibid.

25 Unnumbered order, May 19, 1869, Printed Orders, Fifth Military District; Clarksville standard, July 10, 1869; Sherman to AAG, March 31, 1869, Letters Received, Fifth Military District records. 
"Yellow Jack," as yellow fever was commonly called, and Asian cholera were feared on the Gulf Coast. In 1866 the Army prepared a series of health rules for the state to ensure against the entrance of contagious diseases from a tropical port. Ships arriving from the West Indies were subjected to a twenty-day quarantine and inspection by a health officer. Ships found to be disease-ridden were sealed off and clothing and cargo burned if necessary. The whole vessel was thoroughly fumigated and the crew and cargo were not allowed ashore until fifteen days after the last case was cured. The quarantine laws were in effect from March 7 to September 29.26

In addition to the sequestration of diseased ships, the Army ordered a general cleanup of all towns and camp areas. Decayed matter was ordered buried, sinks and privies were filled with dirt regularly, lime was used to keep buildings dry, and personal cleanliness was enforced. Army medical officers were told to investigate all rumors of disease, especially those involving discharges of the bowels. The Galveston Daily News supported the sanitation orders and suggested that the Army commander and the mayor divide the city into cleanup districts to achieve maximum results. 27

The success of the Army's sanitation program in 1866 led to its repetition the following year. Extensive health ordinances were drawn up by the military. If civil authorities did not keep pace with these orders, the Army took over local health facilities and appointed

\footnotetext{
${ }^{26} \mathrm{GO} 10$, March 7, GO 12, March 19, GO 13, March 21, so 11, September 29, 1866, Printed Orders, District of Texas. $27_{\mathrm{GO}} 16$, April 14, 1866, ibid.; Galveston Daily News, May 28, 1866.
} 
doctors to assist them. In spite of all precautions, the dreaded Yellow Jack landed at Indianola in July, and Austrian troops fleeing from Mexico also brought the disease across the Rio Grande to Brownsville. ${ }^{28}$ The Brownsville Daily Ranchero noted that the economy of the town would collapse without trade, but it was either that or death. "This question is for the military to decide," concluded the newspaper, "not us." General Reynolds quickly placed a rigid quarantine on the port city, turning down many lucrative bribes in the process. 29 On August 10 Sheridan wrote to Grant that yellow fever "of a malignant type" was spreading in the Fifth Military District; he recommended that all detached officers remain elsewhere until October 15. Sheridan added that in Galveston the suffering was of tremendous proportions. By early september the city had no more military surgeons; they had all died of the fever. Two weeks later General Griffin himself succumbed to the disease. ${ }^{30}$ In Hempstead alone, thirty-five soldiers and 103 townspeople died. It took Huntsville ten years to recover from the economic stagnation and death caused by yellow fever in 1867. During the epidemic, the residents of Anderson begged the

28 GO 16, April 24, 1867, Printed Orders, District of Texas; San Antonio Herald, May 22, 1867; Griffin to AAG, July 3, 1867, Telegrams Received, Fifth Military District records; Hobart Huson, Refugio: A Comprehensive History of Refugio County from Aboriginal Times to $19 \overline{5} 3$ (2 vols., Woodsboro, Texas, 1953), II, 127-28, William Lawrence Haskin, The History of the First Regiment of Artillery From Its Origin in 1821

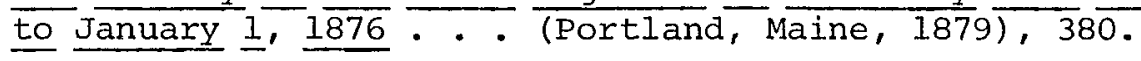

${ }^{29}$ Brownsville Daily Ranchero, August 3, 18, 21, 1867; so 94, July 8, 1867, Sub-district of the Rio Grande, House Executive Documents, 40 th Cong., 2nd Sess., No. 342, 207.

${ }^{30}$ Sheridan to Grant, August 10, 20, 23, September 3, 1867, Grant to Sheridan, August 26, 1867, Grant papers; GO 28, August 26, GO 29, September 5, GO 30, September 9, unnumbered circular, september 15, GO 33, October 9, 1867, all in Printed Orders, District of Texas. 
Army commander there to enforce the quarantine to save the town. 31 It was November before Texans and the Army could rest their fears of the contagion. 32

In the following spring the Army repeated its sanitation orders, this time strengthening the provisions by adding a $\$ 100$ fine and a thirty-day jail sentence for violators. The quarantine ran from May 1 to November 1, 1868. The surgeon-in-chief, District of Texas, also issued new instructions on ship inspection procedures. No one was allowed off a ship until it was inspected. All ships were to be quarantined for three weeks upon arrival or for three weeks after the last known case had been cured. Detailed descriptions of how to fumigate an infected vessel were included. ${ }^{33}$ In 1869 the previous orders on diseases were repeated, and the quarantine period ran from May 26 to November 1. Both years were relatively free of incidents. ${ }^{34}$

Texas suffered from Asiatic cholera concurrently with yellow fever. The cholera outbreaks, however, were much less severe. United

${ }^{31}$ A History of Texas: History of Milam, Williamson, Bastrop, Travis, Leee, and Burleson Counties (Chicago, 1893), 242; Harry F. Estill, "The Old Town of Huntsville," The Quarterly of the Texas state Historical Association, III (1899-1900), 276; Frank MacD. Spindler, "The History of Hempstead and the Formation of Waller County," Southwestern Historical Quarterly, LXIII (1959-60), 419-20; Citizens of Anderson County to Capt. Randlett, October 3, 1867, Governor's papers (Pease).

32 E. D. Townsend to AAG, November 11, 12, 1867, Letters Received, Fifth Military District records.

${ }^{33}$ GO 23, May 1, GO 34, June 5, GO 16, October 19, 1868, Printed Orders, Fifth Military District; GO 11, May 11, GO 12, June 10, Go 13, June 13, 1868, Printed Orders, District of Texas.

${ }^{34}$ GO 104, May 26, GO 184, October 18, 1869, Printed Orders, Fifth Military District. 
States Army recruits brought the disease to Austin in 1866 but their immediate seclusion prevented its spread. In the spring of 1867 cholera again struck, prompting the Army to issue instructions on its prevention. Medical authorities recommended adequate ventilation of buildings, general cleanliness, and a liberal application of quick lime, charcoal powder, chloride of lime, sulphate of iron, and permanganate of potassium to privies, cellars, stables, bed pans, sickrooms, and closets in varying amounts and combinations. ${ }^{35}$ The Army also supplied medical assistance and rations to the beleaguered population after such natural disasters as tornadoes and hurricanes. 36 These illustrations merely emphasize the immensity of the Army's involvement in Texas. Another indication of the reliance placed on the Army's domination of the state is the frequent troop requests received by headquarters. Soldiers were asked to assist the Freedmen's Bureau secure Negro rights and to help force Negroes to work on plantations. 37 Whenever Unionists feared reprisals, they complained to the nearest military post. Loyalists also reported "rebel" sympathizers who held local offices and recommended their replacement. ${ }^{38}$ Republi-

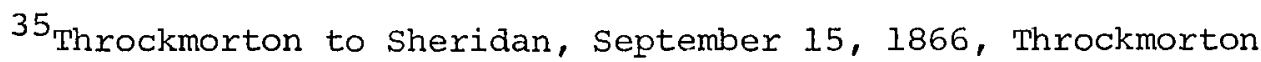
papers; GO 13, April 10, Cixc. 11, April 16, 1867, Printed Orders, District of Texas.

${ }^{36}$ Haskin, The History of the First Regiment of Artillery, 246-47; So 159, October 30, 1867, Sub-district of the Rio Grande, House Executive Documents, 40th Cong., 2nd Sess., No. 342, 208.

${ }^{37}$ SO 64 , April 11, 1867, so 115, May 27, 1867, so 17, January 25, 1868, Printed Orders, District of Texas; Dallas Herald, December 7, 1867; Reynolds to AAG, January 24, 1868, Letters Received, Fifth Military District records.

${ }^{38}$ Griffin to Throckmorton, February 6, 1867, Governor's papers (Throckmorton); First Lt. J. T. Kirkman to AAG, April 30, 1867, Mary Jane Houston to AAG, January 21, 1868, Letters Received, Civil Affairs, 
can members of the constitutional convention of 1868-1869 wanted Army bodyguards to protect them fxom assassination. ${ }^{39}$ The Army also had to police all local elections; this demand resulted in depleted garrisons' sending a handful of men to each county seat. 40 Most common were the requests to stop desperadoes and raiders from terrorizing small towns which lacked local law enforcement. ${ }^{41}$ If a local sheriff did not investigate a crime to the satisfaction of the victim, the citizens might ask the Army to send a military investigator to the scene. 42 Witnesses refused to testify at trials without military protection, ${ }^{43}$ and sheriffs commonly petitioned post commanders for escorts while transporting prisoners to jail, conducting executions, or preventing

Fifth Military District records; Officers and Registrars of Dallas County to AAG, February 15, 1868, Letters Received, Fifth Military District records.

${ }^{39}$ Ham Duval and others to AAG, August 28,1868 , Letters Received, Fifth Military District records.

40 Bvt. Maj. S. M. Whitside to AAG, October 30, 1869, ibid.

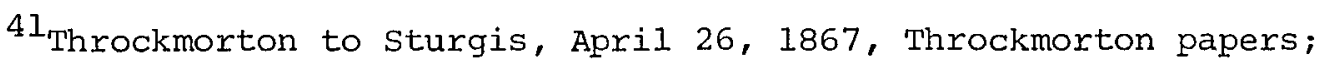
E. M. Pease to Bvt. Brig. Gen. James Oakes, August 30, 1867, Oakes to Pease, October 2, 1867, Canby to Pease, December 31, 1868, Governor's papers (Pease); Richard Lecke to AAG, December 22, 1867, Letters Received, District of Texas records; Sheriff N. B. Ferguson to AAG, September 3, 1868, Letters Received, Fifth Military District records; Canby to Pease, December 31, 1868, AAAG to G. W. Paschal, January 16, 1869, Letters Sent, ibid.; Pease to Reynolds, June 22, 1869, in "Transcript of Records, 1838-1869"; A. Bledsoe to AAG, September 14 , 1869, James E. Brady to AAG, February 9, 1870, Letters Received, Civil Affairs, Fifth Military District records.

42 J. L. Farquar to AAG, February 21, 1868, Letters Received, Civil Affairs, Fifth Military District records; Dr. J. N. Williams to AAG, July 22, 1868, Letters Received, District of Texas records.

${ }^{43}$ George K. Leet to AAG, January 18, 1869, Luetters Received, Fifth Military District records. 
lynchings. ${ }^{44}$ post commanders were constantly requesting more men to fulfill these obligations, 45 and a lack of personnel led headquarters to refuse many requests for assistance after 1869.46

The continual shifting about of garrisons from one area to another created an immense logistical problem. 47 Even before the war when only the frontier posts had existed, supplying the troops had

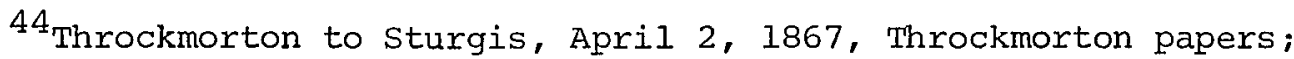
Throckmorton to Chief Justice, Iampasas County, May 30, 1867, Executive Correspondence; Oakes to Throckmorton, June 12, 1867, J. B. McFarland to Pease, December 4, 1868, Governor's papers (Pease); So 191, October 26, 1867, District of Texas, in House Executive Documents, 40th Cong., 2nd Sess., No. 342, 206.

${ }^{45}$ Griffin to AAG, April 1, 1867, Bvt. Brig. Gen. Julius Hayden to AAG, september 3, 1868, First Lt. A. H. M. Taylor to AAG, December 25, 1868, Bvt. Col. S. H. Starr to AAG, November 4, 1869, Letters Received, Fifth Military District records; Capt. Edward Collins to AAG, May 26, 1867, Letters Received, District of Texas records; AAG to Bvt. Brig. Gen. George P. Buel, June 30, 1869, Letters Sent, Fifth Military District records.

${ }^{46}$ Secretary of Civil Affairs to Samuel W. Moorehead, June 2, 1869, Secretary of Civil Affairs to A. MCWiggenton and others, July 8, 1869, Letters Sent, Civil Affairs, Fifth Military District records; Bvt. Lt. Col. J. S. Stewart to AAG, February 1, 1869, Letters Received, Fifth Military District records. Officers found themselves running errands en route to duty stations to make up for the lack of personnel, e.g.., so 95, May 24, 1867, Printed Orders, District of Texas. Part of the shortage was caused by a reduction and consolidation of Army regiments by order of Congress. See GO 20, March 4, 1869, ibid.; Reynolds to AGO, May 26, 29, 1869, Letters Sent, Fifth Military District records. Civilian laborers and teamsters were reluctantly employed to free soldiers from menial tasks. See GO 1, January 1, 1866, GO 4, January 25, 1866, Printed Orders, District of Texas; So 63, June 7, 1867, GO 26, May 4, 1868, Printed Orders, Fifth Military District; AAG, Galveston to AAG, New Orleans, April 5, 1867, Letters Received, Fifth Military District records.

47 Another question created by the change of posts was unique to Texas among the western states and territories. Texas was the only state in the Union in which there were no public lands, which meant that all posts had to be purchased or leased from the state or private landowners. See Capt. Edward Collins to AAG, May 19, 1868, Letters Received, District of Texas records; Reynolds to AGO, March 7, 1870, in House Executive Documents, 41st Cong., 2nd Sess., No. 228, 1-2. 
been difficult ${ }^{48}$ during Reconstruction the task multiplied severalfold because the Texas command was plagued by a lack of transportation. Troop movements to the state had to be delayed until mid-June 1865 when a sufficient number of steamers could be obtained. Sheridan complained that his men were being shipped westward at a "snail's pace." The Army was forced to reconstruct the wharves at Indianola, and the engineers built seventy miles of railroads inland from that port. Another line was to be laid in the Rio Grande Valley, but when Washington threatened to prevent its construction, Sheridan wrote to Grant that "it seems like a want of reflection or a suggestion on the part of some old man who was in the Mexican war, when we got along without it." Sheridan also expressed his hope that "these people will die off" soon for the benefit of the service. Grant approved of the construction. 49 After the troops arrived in Texas, they found themselves limited to coastal operations. Major General David S. Stanley said he had enough soldiers "to smear all over the country, the only difficulty being the question of transportation." The best port in Texas was Galveston, but it was too far east to adequately supply the frontier garrisons and lacked rail connections with the northern part of the state. For this reason, Indianola and Jefferson became important

48 Arrie Barrett, "Federal Outposts in Texas, 1846-1861" (Unpublished M.A. thesis, University of Texas, Austin, 1927), 39. The difficulties of transporting materiel across the vast plains of Texas led to an experimental use of camels as beasts of burden. See Leo Edwin Mahoney, "The Camel Corps: An Attempted Solution of the Problems of Western Transportation" (Unpublished M.A. thesis, University of Texas, Austin, 1928), 1-18.

${ }^{49}$ Sheridan, Personal Memoirs, II, 213; American Annual Cyclo-

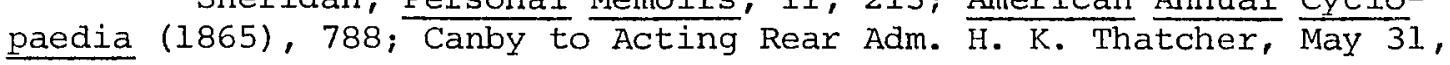
1865, …‥, XLVIII, Pt. 2, 692; Sheridan to Rawlins, June 12, 19, August 5, 1865, Grant papers; So 10, June 30, 1865, Printed Orders, District of Texas. 
supply centers. Supplies were gathered in New Orleans and transported to Brashear, Louisiana, by rail. There the supplies were loaded into coastal vessels and shipped to Indianola. The materiel then went by rail to Cuero near San Antonio, where it was loaded into wagons. The wagons made the last leg of the journey to San Antonio where the supply columns were parceled out to the posts along the California Trail and the western frontiex. The interior garrisons were provisioned from Jefferson, which received its goods through the Red River system by steamboat from New Orleans. From Jefferson the materiel was transported by wagons to the various posts in eastern Texas. When the military's role in Reconstruction ended in 1870, Jefferson was abandoned for an alternate route from Galveston through waco to the northwestern frontier. The Rio Grande Valley was always supplied via Brownsville. 50

The difficulty of supplying the Army in Texas was augmented by a lack of communication between posts. The numerous forts along the Texas frontier were connected by the telegraph but not until 1875 . The interior garrisons never had good communication. In one instance the post commandant at Bryan Station was ordered to send a courier to find the headquarters of three companies of the Fifteenth Infantry. The companies had left Nacogdoches several weeks earlier and were lost somewhere in the pine forests of "Deep East" Texas. Reliable

50 Lowel1 H. Harrison, "Supplying Texas Military Posts in 1876," Texas Military History, IV (1964), 23; Maj. Gen. D. S. Stanley to Hamilton, August 8, 1865, Governor's papers (Hamilton); Sheridan to Rawlins, November 14, 1866, O.R. , XLVIII, Pt. 1, 299; Canby to AGO, February 1, 1869, Reynolds to Bvt. Maj. Gen. Montgomery C. Meigs, April 7, 1870, Letters Sent, Fifth Military District records. The roads in Texas were uniformly bad. See Capt. Eugene Carter to AAG, February 23, 1869, Letters Received, ibid. 
communication was possible only between Galveston, Austin, and San Antonio. 51

The Army had to handle many tasks during Reconstruction. Many of these seemed senseless to West Pointers, but they resulted from the military's complete domination of state government. In spite of the various non-military responsibilities and their own logistical problems, the officers and men did their best in a most difficult situation.

${ }^{51}$ On the telegraph, see L. Tuffly Ellis (ed.), "Lt. A. W. Greely's Report on the Installation of Military Telegraph Lines in Texas, 1875-1876," Southwestern Historical quarterly, LXIX (1965-66), 67, 69; Sheridan to Rawlins, November 15, 1865, Grant to Maj. Gen. H. W. Halleck, November 16, 1866, Grant papers; E. D. Townsend to AAG, February 11, 1868, Letters Received, Fifth Military District records. For the lost companies of the Fifteenth Infantry, see AAAG to CO, Post of Bryan, June 19, 1869, Letters Sent, Fifth Military District records. 


\section{UNDENIABLE TRUTHS}

In 1865 Lilly Barr would not have spoken to a Federal soldier; by 1867 she was actively associating with the young bachelor officers stationed in her home town of Galveston. One fine spring day when Lilly was out promenading her new hat she met Captain McLean, a friend of hers in the Sixth Cavalry, and General Griffin. Lilly stopped to flirt with Captain McLean who jovially remarked that her hat was too small and she would be burned black by the glaring sun. "Oh," Lilly replied, "well that is alright, . . . you'll like me better then." All three broke out in laughter. Lilly's remark might have cost her some embarrassing moments immediately after the war but things had changed since 1865. This modification in the attitude of the Army and Freedmen's Bureau bore an ominous sign for the black race and its hopes and aspirations in Reconstruction Texas. ${ }^{1}$

In the last analysis, the primary issue of Reconstruction was the Negro and his relationship to the white majority in American society. The Civil War had begun over secession and culminated in freedom for the slaves. Reconstruction promised a revolution in the entire social structure of American society. It was over the issue of equality that the South drew the final battle line--and won because the North lacked the commitment necessary to force the issue to a

\footnotetext{
${ }^{1}$ Amelia Barr to Jennie, June 3, 1867, Amelia Barr papers, Archives, University of Texas.
} 
successful end. ${ }^{2}$ The history of the Negro in Texas after the Civil War provides a graphic illustration of this point.

During the Civil War, Texas had remained pleasantly remote from the horrors of the battlefields. There were few engagements, no massive cavalry raids, and good crop conditions. The neighboring states of Missouri, Arkansas, and Louisiana, however, did not fare so wel1. When the Yankees invaded these states, the slaveholders saw Texas as a haven from the ravages of war. Slowly at first, then in droves, the residents of the Trans-Mississippi area sent their bondsmen to Texas for safekeeping. There were 275,000 slaves in Texas in 1861. By 1865 the black population had risen to $400,000 .^{3}$

To solve the problems brought on by the end of the war and emancipation, Congress set up a new agency on March 3, 1865. The Bureau of Refugees, Freedmen, and Abandoned Lands illustrated by its title the problems that faced the South. This agency was more commonly known as the Freedmen's Bureau and was to last for the duration of the

${ }^{2}$ See C. Vann Woodward, "Equality: The Deferred Commitment," The American Scholar, XXVII (1958), 459-72.

${ }^{3}$ These figures are in round terms. See Bancroft, History of the North Mexican States and Texas, II, 480. The figures in Wallace, Texas in Turmoil, 153, $20 \overline{0,000}$ for 1861 and 400,000 for 1865 , are closer to the 1860 census which lists 182,566 slaves. Joseph $\mathrm{C}$. G. Kennedy (comp.), Population of the United States in 1860 . . (Washington, 1864), 479, 483. The historian of Matagorda County claims that so many Negroes were sent there from the rest of the South during the war, that it took until 1910 for the whites to obtain a majority in numbers. John Columbus Marr, "The History of Matagorda County, Texas" (Unpublished M.A. thesis, University of Texas, Austin, 1928), 163. The 1870 census, however, shows a substantial decrease in Negro population when compared to the 1865 figures. Francis A. Walker (comp.), The Statistics of the Population of the United States . . (Washington, 1872), 65 . 
war and one year thereafter. ${ }^{4}$ Even though it was separate from the Army, its commissioner was Major General Oliver Otis Howard, and many sub-assistant commissioners of the Bureau were Army officers. In Texas, if a post area had no Freedmen's Bureau representative, the commanding officer of the nearest Army detachment automatically assumed those duties in addition to his troop assignment. 5

The Freedmen's Bureau in Texas was headed by five men, ${ }^{6}$ and all of them were conservative in action, if not words, in their approach

${ }^{4}$ U. S., Statutes at Large, XIII, 507. General works on the Bureau include Oliver Otis Howard, Autobiography (2 vols., New York, 1908); Paul Skeels Pierce, The Freedmen's Bureau: A Chapter in the History of Reconstruction (Iowa City, 1904); W. E. Burghardt Du Bois, "The Freedmen's Bureau," Atlantic Monthly, LXXXVII (1901), 354-65; John and La Wanda Cox, "General Howard and the 'Misrepresented Bureau,'" Journal of Southern History, XIX (1953), 427-56; George R. Bentley, A History of the Freedmen's Bureau (Philadelphia, 1955); John A. Carpenter, Sword and Olive Branch: Oliver Otis Howard (Pittsburgh, 1964); William S. McFeely, Yankee Stepfather: General 으. ㅇ․ Howard and the Freedmen (New Haven, 1968). On Texas, the standard study of the Bureau is Claude Elliott, "The Freedmen's Bureau in Texas," Southwestern Historical Quarterly, IVI (1952-53), 1-24. An excellent analysis of the Texas Bureau personnel is Lonnie Sinclair, "The Freedmen's Bureau in Texas: The Assistant Commissioners and the Negro" (Unpublished paper submitted to the Institute of Southern History, The Johns Hopkins University, Baltimore, July 22, 1969, manuscript in the author's possession). The author would like to express his thanks to Mr. Edward Rademaker for drawing his attention to this paper.

${ }^{5}$ Circ. 3, February 1, 1867, Printed Orders, District of Texas. Some Texas civilians asked to be made sub-assistant commissioners. See G. M. Martin to Gov. A. J. Hamilton, August 1, 1865, Governor's papers (Hamilton); Sam L. Earle to Hon. James H. Bell, October 13, 1865, James H. Bell papers; Throckmorton to Brig. Gen. J. B. Kiddoo, October 25, 1866, Throckmorton papers.

6 The five heads of the Bureau in Texas and their dates of appointment are as follows: Maj. Gen. Edgar M. Gregory, September 21, 1865; Brig. Gen. Joseph B. Kiddoo, April 2, 1866; Maj. Gen. Charles Griffin, January 24, 1367; Maj. Gen. Joseph J. Reynolds, September 21, 1867, and April 8, 1869; and Maj. Gen. E. R. S. Canby, January 18, 1869. Canby served less than three months and had little influence on Bureau policy in the state. See Pierce, Freedmen's Bureau, 47-48, 174; Bentley, History of the Freedmen's Bureau, 216. 
to the Bureau's responsibilities. ${ }^{7}$ The most controversial head of the Texas Bureau was its first assistant commissioner, Major General Edgar M. Gregory. Howard appointed Gregory to the Texas position because he was fearless, and Howard felt that Texas was a post of great peril. Gregory was the only one of the state commissioners who was a radical abolitionist, a fact which did not endear him to the white population of the state. 8

Gregory had conflicting ideas about the character of the ex-slaves. He felt they were respectable people with an unquestionable right to social and political equality. They were also docile and patient, thought Gregory, "strongly impressed with religious sentiment, and their morals are equal if not superior to those of a majority of the better informed and educated" in Texas. At the same time, however, the general felt that he personally was superior to any black. Gregory saw as his prime task the establishment of a free labor system and he made an extensive tour of the former slaveholding areas of Texas to speak to whites and blacks. The general encouraged the Negroes to stay at home and work and to sign labor contracts as well as to work for a share of the crop or wages. On his speaking

7 The goals of the Bureau were to introduce and promote a system of compensated labor, provide for the destitute, aged, and sick, establish Negro schools, protect loyal, white refugees, and adjudicate differences between blacks and whites when civil courts proved inadequate. There were few abandoned lands in Texas, and the white refugees in the state tended to depend upon the regular Army, not the Bureau agents. See Elliott, "Freedmen's Bureau in Texas," 3; Pierce, Freedmen's Bureau, 53; Howard, Autobiography, II, 243; Ramsdel1, Reconstruction in Texas, 74-75.

8 Bentley, History of the Freedmen's Bureau, 60; McFeely, Yankee Stepfather, 72-73; Elliott, "Freedmen's Bureau in Texas," 2; Howard, Autobiography, II, 218. Gregory's military career is outlined in Heitman, Historical Register, I, 477. 
tour, Gregory passed out printed copies of "acceptable" contracts to serve as guides for the planters and fieldhands during labor negotiations. Above all, Gregory attempted to still the persistent rumor that the freedmen would receive forty acres and a mule at Christmas. ${ }^{9}$ Although Gregory did little more than encourage the Negro to stay at home, sign a contract, and work for his former master, his reports to Washington and his assertions that the blacks were equal, if not superior, to the Texas whites caused him immediate trouble. Gregory was also unpopular because he increased Army patrols in plantation areas and enforced contract terms at the point of a bayonet. In short, he was much too conscientious, and complaints of his conduct flooded military headquarters in Galveston, New Orleans, and Washington. Howard asked for an investigation to be undertaken by General Wright, commander of the District of Texas. Wright remarked that Gregory was a good officer who worked hard at his job, but he felt there was no denying that the assistant commissionex was a highly unpopular man and that someone with more tact might fare better in the position. Shortly thereafter, David G. Burnet, an important pre-war Texas politician, accused Gregory of fomenting racial unrest with his anti-white speeches and of being too inclined to accept the freedman's side of a controversy. Burnet's accusations reached President Andrew Johnson who referred them to Howard. The commissioner of the Bureau personally never doubted Gregory's integrity, but he succumbed to the political pressures brought against him and promoted Gregory to an inspector

${ }^{9}$ Circ. 1, October 12, 1865, Texas Freedmen's Bureau, R.G. 105, National Archives; Sinclair, "Freedmen's Bureau in Texas," 2-3; Elliott, "Freedmen's Bureau in Texas," 1-3; Ramsdell, Reconstruction in Texas, 72-73. 
general's position, thus removing him from Texas. Gregory's greatest sin was trying to make the ex-slave free in fact, not just on paper. The joy of Texans at his removal can be seen in the one sentence comment which appeared in the conservative Galveston Daily News: "Gen. Gregory left yesterday for New Orleans!"10

Gregory's replacement was Brigadier General Joseph B. Kiddoo. Like his predecessor, Kiddoo was a civilian who had joined the Army in 1861 and advanced to the rank of general. Kiddoo had received a severe spinal injury during the war which sometimes affected his ability to handle the rigors of his job. The new assistant commissioner concentrated his efforts on Negro education. He felt that the Negro needed an education to better prepare him for his new life of freedom. Black education was spasmodic at first, but Kiddoo formalized and expanded the school system. He absorbed various missionary association teachers into the Bureau structure and arranged for both the churches and the government to pay them. In this manner, he hoped to attract good personnel with higher salaries. Kiddoo established a black normal school at Galveston and began a program to educate the colored troops along the Rio Grande. The general wanted those soldiexs to stay in Texas and teach after their muster-out. Kiddoo also

${ }^{10}$ Gregory later took over the Bureau's operations in Maryland. see Sinclair, "Freedmen's Bureau in Texas," 4-6. Elliott, "Freedmen's Bureau in Texas," 10-11; Bentley, History of the Freedmen's Bureau,

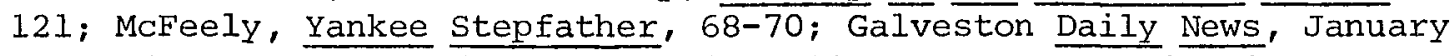
28, 1866, June 20, 1866. Gregory's policy can be seen in his reports to Howard, December 9, 1865, January 31, 1866; Brig. Gen. William E. Strong to Howard, January 1, 1866, Dr. I. J. W. Mintzer to Gregory, January 31, 1866, all in House Executive Documents, 39th Cong., 1st Sess., No. $70,304-13,37 \overline{4-77}$. 
abolished Gregory's tuition plan and set up free schools. 11

Kiddoo's desire to educate the blacks met severe opposition in the state. Texans resented the evangelical fervor of the Yankee teachers who felt they were God's chosen instruments to "save" the South. Texans claimed that the Negroes were too sub-human to be educated successfully and resented the Yankees proving them wrong. The whites also believed that those who taught Negroes placed themselves on the same social level as their students. The state newspapers ridiculed the blacks' ignorance and attempted to show the freedmen to be no more than uneducable children. At the same time, schools were burned out, teachers threatened, and students intimidated. One woman in Houston reportedly said that she would sooner put a bullet in a Negro than see him educated. 12

In spite of the obstacles, Lieutenant E. M. Wheelock, the Bureau's superintendent of education, reported that one hundred-eighty schools had been established in the state with 4,400 students. When he turned the schools over to the Reverend Joseph Welch in 1867, Wheelock was pleased with the results and estimated that 10,000 Negroes had learned to read and write. As the educators persisted, white

${ }^{11}$ Sinclair, "Freedmen's Bureau in Texas," 8; Elliott, "Freedmen's Bureau in Texas," 12-14; Howard, Autobiography, II, 195-96; Circ. 20, August 31, 1866, Texas Freedmen's Bureau. See also, Henry Lee Swint, The Northern Teacher in the South, 1862-1870 (Nashville, 1941), 26-32. For Kiddoo's career, see Heitmen, Historical Register, I, 596 .

12 The Negro schools were a favorite target for Ku KIux KIan raids. See William Garrott Brown, "The Ku Klux Klan Movement," Atlantic Monthly, LXXXVII (1901), 642; Howard, Autobiography, II, 377, 384-85; Bettie Hayman, "A Short History of the Negro of Walker County, 1860-1942" (Unpublished M.A. thesis, Sam Houston State College, Huntsville, 1942), 18-19; D. J. Baldwin to Hamilton, November 7, 1865, Governor's papers (Hamilton); Elliott, "Freedmen's Bureau in Texas," $21-2 \dot{4}$. 
Texans began to cautiously support the black schools for the first time. By June 30, 1870, when the Freedmen's Bureau withdrew from the state, the schools remained its only really successful program. ${ }^{13}$ Kiddoo, however, did not last as long as his schools. He suffered from uncooperative civil authorities who resented his unwillingness to condone the Black Codes. General Heintzelman sided with the state government and removed several of Kiddoo's staff officers, thus severely limiting the Bureau's effectiveness. Finally the Bureau was being placed under more direct control by the Army. This entailed joining together the office of district commander and assistant commissioner. When this was done, Kiddoo resigned rather than be subordinated to the regular chain of command. "Gen. Kiddoo had managed the Bureau rather satisfactorily," commented the Galveston Daily News when the general left the state, "which we think is more than can be said of any other of the heads of the Bureau." 14

The new assistant commissioner was the next commander of the Department of Texas, General Griffin. Griffin's chief contribution to the work of the Bureau was the extension of its tentacles of control into every corner of the vast state. At the same time, however, he abolished free schools and reintroduced a tuition system which severely curtailed attendance. The expansion of the Bureau was also hindered by the focus of attention in Texas on the political demands placed on the South by Congress. The passage of the Reconstruction Acts and the consolidation of the army district commander and the assistant commis-

13 Elliott, "Freedmen's Bureau in Texas," 7-10, 16-18, 24.

${ }^{14}$ Sinclair, "Freedmen's Bureau in Texas," 10-11; Galveston Daily News, February 5, 1867. 
sioner into one position caused the Bureau post to lose its identity in the mass of problems involving voter registration, law and order, and black representation on juries. The job was really too much to expect of one man, and Griffin and his successor, General Reynolds, tended to ignore Bureau duties and concentrate on the military aspects of the job. The situation deteriorated even further when the officer in charge of the Fifth Military District, General Hancock, prohibited Bureau authorities from interfering with civil courts, and separated local troop units from Bureau control. With the readmission of Louisiana into the Union in 1868, Reynolds was forced to assume command of the Fifth Military District in addition to his other duties--one more burden that cost the Bureau his attention. On December 31, 1868, all functions of the Freedmen's Bureau except education were ended in Texas. Four months later Howard notified the general that the position of assistant commissioner in Texas had been discontinued. ${ }^{15}$

If the assistant commissioners were relatively conservative, other factors must explain the condemnation the Bureau received in Texas. Part of the answer lay in the fact that the overburdened commissioners relied heavily on local agents to formulate and carry

${ }^{15}$ Reynolds to AAG, February 19, 1868, Letters Received, Fifth Military District records; Sinclair, "Freedmen's Bureau in Texas," 11-19; Elliott, "Freedmen's Bureau in Texas," 14-16; Howard, Autobiography, II, 342-43; Wallace, Texas in Turmoil, 157; McFeely, Yankee Stepfather, 293, calls the Army officers who took over the Bureau "illdisposed to the freedmen." Undoubtedly some were, but in Texas Griffin and Reynolds were less "ill-disposed" than overworked. Both men tried to develop a private company to help Negroes sell their crops independently from the planter, but their failure was due more to their preoccupation with other tasks than it was to lack of sympathy with the blacks' condition. This may also explain why the later assistant commissioners appeared to support President Johnson's policy of ignoring the potential power of the Bureau (ibid., 196-97). 
out policy. Texas had sixty-eight sub-assistant commissioners--more than any other state. Even so, because the state was so large, the efforts of these men to regulate labor were likened to "tickling a rhinoceros with a straw." Although there were many kinds of agents, southern whites accused all of them of dishonesty and mismanagement. Given the circumstances under which they had to work, the local agents found it an almost impossible task to maintain impartiality between the races. 16

The catalogue of complaints against the sub-assistant commissioners was lengthy. "We have borne patiently and silently for some time, the arrogant assumption of arbitrary power by the Freedmen's Bureau," wrote a Galveston editor, "until we can no longer hold our peace . . ." The editor was upset about the arrest of a white man because he had orally condemned the Bureau to the devil. The citizen had had a quarrel with a Negro over the possession of a turkey. The black obtained a Bureau order giving him the turkey but the white man had refused to comply. This type of encounter and the Bureau's willingness to arrest any white over a seemingly trivial matter was a typical complaint. In Tyler a white man claimed a Negro had intentionally pushed his "big fat wife" against a white woman causing her to fall down on the sidewalk. When the white man seized and hit the Negro, the Freedmen's Bureau agent had him arrested for assault. To Texans who were used to settling personal affronts without troubling the law, this was tyranny. 17

\footnotetext{
16 Bentley, History of the Freedmen's Bureau, 136, 137, 139; McFeely, Yankee Stepfather, 72 .
}

17 Galveston Daily News, January 8, 1867; Sue Estella Moore, 
In another case William Burton of Houston testified that he had been confined indefinitely without bail after having been tried for the murder of three freedmen. He asked that the legal process be completed or that he be released on parole. Bureau agents were accused of shielding blacks from civil courts. The agent in Bosque County released a Negro charged with rape even though his decision was based on hearsay evidence. The same agent threatened the county sheriff with military arrest when he protested the release. A black indicted for assault in Matagorda County was released in a similar manner. The Grimes County sheriff was denied permission to extradite a prisoner who had escaped to the Freedmen's Bureau headquarters in nearby Harris county. While there may have been extenuating circumstances, the white citizens saw the Bureau as a biased force which prevented justice. 18

There were numerous protests against the Bureau's interference with private property. John Corbett of Galveston indignantly wrote Governor A. J. Hamilton that the "so-called Freedmen's Bureau" had seized some land he had bought in 1859 from a free woman of color. The woman told the Bureau that Corbett had expropriated the property, but Corbett insisted he had paid $\$ 2,800$ for it and that her lawyer had drawn up the agreement. From Corpus Christi came a letter from Mrs.

\footnotetext{
"Life of John Benjamin Long" (Unpublished M.A. thesis, University of Texas, Austin, 1924), 55-56.

${ }^{18}$ John R. Chite to AAG, January 7, 1868, Anonymous to AAG, January 9, 1868, Letters Received, Civil Affairs, Fifth Military District records; Throckmorton to Kiddoo, November 7, 1866, Throckmorton to Griffin, December 18, 1866, Throckmorton papers; Throckmorton to Andrew Johnson, December 22, 1866, January 8, 1867, Johnson papers; Kiddoo to Throckmorton, January 3, 1867, "Transcript of Records, 18381869"; Elliott, "Freedmen's Bureau in Texas," 19.
} 
Margaret E. Love asking for relief from the Army for $\$ 2,500$ worth of her property which had been seized by the Bureau. Other seizure complaints and an accusation that a sub-assistant commissioner suspended a court order relative to the will of the estate of a Robertson County man were received. It is possible some of this property may have been confiscated from Unionists during the war and sold by the Confederate government. In such cases the Freedmen's Bureau was assigned the task of recovering the loss. 19

Many complaints against the Bureau concerned its courts which had been organized by General Kiddoo although they had operated sporadically prior to this time. According to the rules, the courts had jurisdiction only in cases involving Negroes or in those in which the civil court system was deemed untrustworthy or prejudiced against black testimony. The courts ruled in favor of blacks in certain areas and whites in others, depending on local circumstances. One historian finds that of 286 cases tried in fifteen Bureau courts, 194 were settled in favor of Negroes and ninety-two in favor of whites. General Griffin felt that the lack of uniform procedure in the Bureau courts resulted in valid criticism and therefore withdrew much of the authority of local agents to conduct trials. The process was further limited by General Hancock who transferred all cases involving legal questions to the civil courts in Louisiana and Texas. Hancock warned Bureau agents not to interfere with civil authorities in such instances. This 
meant the sub-assistant commissioners could only seize property if there was "clear and positive" evidence that the landholder had tried to cheat his laborers out of their wages and after the state authorities had refused to act. 20

The Freedmen's Bureau and the civil government of Texas were at odds throughout the Bureau's sojourn in the state. "While I am ready to acknowledge that many wanton wrongs are perpetrated upon black people," remonstrated the elected governor, James W. Throckmorton, to General Griffin, "yet I cannot but mention it is a singular fact that while it is notorious that the blacks themselves commit many wrongs and offer many provocations, still there is scarcely a mention of such occurrences. . . ." Throckmorton was glad the Freedmen's Bureau wanted justice for all men, but he decried the fact that the Bureau courts trusted black testimony alone and assumed the Negroes "are a guiltless, unoffending, and immaculate race." Throckmorton wanted the freedmen treated fairly; something he himself could not impress upon local civil officers despite the many letters he wrote asking that justice be done "every class of the people."2l

The governor was also incensed at the lack of respect shown toward civil authorities by the Bureau agents. Whenever a subassistant commissioner was charged with a crime by local officials,

20 Andrew M. Moore to AAG, December 25, 1867, Samuel M. Scott to AAG, December 30, 1867, Letters Received, Civil Affäirs, Fifth Military District records; Elliott, "Freedmen's Bureau in Texas," 12; Bentley, History of the Freedmen's Bureau, 159, 161, 166; Wallace, Texas in Turmoil, 157 .

21 Throckmorton to Griffin, February 7, 1867, Throckmorton to Chief Justice, Panola County, February 8, 1867, Executive Correspondence. 
the Army would protect him from prosecution. Undoubtedly many of the charges were false, but even obvious cases of criminal activity were shielded from state action. In desperation the governor once wrote Griffin and implored that the "negro or officer in charge" be directed to deliver the Bureau agent of Wharton County to a local court. When an Army officer in Seguin was indicted, the Bureau agent, also an Army officer, seized and burned the court records to prevent a trial. At Victoria, Negroes on their way to the state prison were taken from a peace officer by a Bureau agent who said they had been convicted on insufficient evidence. 22

Texans felt the Freedmen's Bureau to be biased not only in its legal proceedings but also in its tampering with politics. General Sheridan, for example, used the Bureau to set up voter registration districts, recommend people for positions as registrars, and distribute information on political rights to eligible voters. Freedmen's Bureau agents and Yankee school teachers were instrumental in organizing branches of the Union Loyal League, a Republican political front. While they may have had the purest of motives in mind, white Texans felt the political instruction was designed to make the Negroes "soured, dissatisfied, and hostile" with the white population. ${ }^{23}$

22 Fred Barnard to Hamilton, December 25, 1865, Col. Edward Colyer to J. L. Cunningham, March 5, 1866, Cunningham to Hamilton, March 8, 1866, Governor's papers (Hamilton); Throckmorton to Griffin, December 22, 1866, Throckmorton papers; Throckmorton to E. D. Townsend, January 8, 1867, Johnson papers; Griffin to Throckmorton, January 28, 1867, Governor's papers (Throckmorton); Throckmorton to Griffin, February $7,22,1867$, Executive Correspondence.

23 Bentley, History of the Freedmen's Bureau, 185-86, 190, 214, feels that political interference destroyed what little good the Bureau did in the South. Texas historians agree. See Ramsdell, Reconstruction in Texas, 77; Rosemary F. Haynes, "Some Features of Negro Partici- 
Not all Freedmen's Bureau agents were interested in forwarding the condition of the black race. An officer of the Twelfth Illinois Cavalry reported the agent at Livingston did little to assist Negroes in his district. He was a resident of the town and feared reprisals Exom his neighbors if he acted. The agent at Marshall, Lieutenant I. M. Beebe, was pleasantly surprised at the favorable reception he received-particularly because northeastern Texas was a graveyard for most Bureau agents who served there. Beebe's popularity probably hinged on the fact that he had prevented Negroes from leaving their old plantation quarters to wander along the roads. The sub-assistant commissioner at Centerville was understandably popular with the local citizens. He was courting an attractive widow who lived near town and helped her with disciplinary problems by tying up "runaways" by their thumbs. 24

pation in Texas History Through 1879" (Unpublished M.A. thesis, Texas Agricultural and Industrial University, Kingsville, 1948), 77; Bertha Atkinson, "The History of Bell County" (Unpublished M.A. thesis, University of Texas, Austin, 1929), 128; Harrell Budd, "The Negro in Politics in Texas, 1867-1898" (Unpublished M.A. thesis, University of Texas, Austin, 1925), 1-2, 7, 31; William D. Wood, Reminiscences of Reconstruction in Texas, 14-15.

${ }^{24}$ Capt. W. H. Redman to Lt. Col. E. H. Powell, April 16, 1866, House Executive Documents, 40th Cong., 2nd Sess., No. 57, 124; Lt. I. M. Beebe to AAG, May 26, 1866, Letters Received, District of Texas records; Frances Jane Leathers, Through the Years, A Historical Sketch of Leon County, and the Town of Oakwood (Oakwood, Texas, 1946), 53. Brown, "Annals of Travis County," ch. XXVI, 15, notes that the Bureau at Austin required Negroes to handle all civil cases in state courts. There is sufficient evidence of this nature to challenge Ramsdell's statement that as long as the regular Army controlled Reconstruction, "efforts were made to keep the negroes under strict supervision," but that this ended with the arrival of the Freedmen's Bureau commissioners. Ramsdell, Reconstruction in Texas, 48. Too often the Bureau agent and the local post commander were the same person with the same racial attitudes, much to the blacks' dismay. Such evidence also casts doubt on Ramsdell's assertion that the Army "refused to allow coercion on the part of employers" against Negroes. Ibid., 50. 
The Freedmen's Bureau also suffered because of the whites' attitudes and beliefs about the Negro. The whites were not only determined to keep the freedman in an inferior social and economic position, but they even had some reservations about freeing the slaves at all after the war. In June 1865 when General Granger arrived at Galveston to assume command of the District of Texas, he issued General orders No. 3, which declared the slaves free by executive order of the President. Although the San Antonio News expected little opposition to Granger's order, General Gregory found it necessary to repeat its provisions in a new dictate which he published four months later as the first circular of the Freedmen's Bureau. General Gregory had good reason to reissue the freedom order since Texans looked upon emancipation as an unwise and arbitrary confiscation of private property. Planters vainly hoped that they would be compensated for the loss of their slaves or that the Supreme Court or the election of 1866 would overturn the Republicans' majority in Congress. In addition, there was a cotton crop to bxing in that fall. For these reasons, the planters forced their ex-bondsmen to stay on the plantation as slaves in fact, if not in name. To achieve this end, the farmers liberally employed whipping and murder. Blacks who fled their old masters were hunted down with bloodhounds just as before the war. Negroes were still sold as slaves throughout 1865 and, until Union soldiers arrived in the area, slavery continued without interruption, especially east of the Trinity River. 25

${ }^{25}$ GO 3, June 19, 1865, Printed Orders, District of Texas; Circ. 1, October 12, 1865, Texas Freedmen's Bureau; San Antonio News, June 27, 1865; Bancroft, History of the North Mexican States and Texas, II, 481; Ramsdel1, Reconstruction in Texas, 70; Wallace, Texas in Turmoil, 150, 
Those planters who had read Granger's freedom order to their Negroes introduced few changes in the plantation routine. Free Negro labor was seen as an experiment that would probably fail because the innate qualities of the blacks made them unfit for any other station in life. Texans believed their Negroes were childlike, inherently inferior, irresponsible, in need of discipline, and incapable of living as freedmen. Whites feared the only way the blacks could be elevated was through racial amalgamation, a disquieting thought to any "right-thinking" southerner. "Then the kinky hair, the mellow eye, the axtistic nose, the seductive lips, the 'emotional heart,' the gambril shins, the hollowness of foot, the ebony skin and bewildering odor will be ours," moaned one editor, "all ours, ours, ours." The only alternative was to keep the Negroes "in theix places."26

The actions of the blacks duxing the first six months of freedom made the whites more steadfast in their opinion of free Negro

166; Cox, "The Economic History of Texas During the Period of Reconstruction," 1, 29, 30; W. E. Burghardt Du Bois, Black Reconstruction: An Essay Toward a History of the Part Which Black Folk Played in the Attempt to Reconstruct Democracy, 1860-1888 (New York, 1935), 553 . For examples of brutal treatment of Negroes and continued slavery, see the following letters written to Governor Hamilton: Nat Hart Davis, August --, 1865, Thomas Ford, Philip Howard, and L. L. Aicholz, September 6, 1865, S. T. Richardson, September --, 1865, John E. Thompson, October 8, 1865, Governor's papers (Hamilton). See also, Hamilton to President Johnson, October 21, 1865, Johnson papers; Wright to AAG, July 21, 1866, Sheridan papers.

${ }^{26}$ Ramsdel1, Reconstruction in Texas, 70; Cox, "Economic History of Texas," 31, 38, 40; Hayman, "A Short History of the Negro of Walker County," 13, 21-22; Cole, "The Texas Career of Thomas Affleck," 201-202; Brownsville Daily Ranchero, April 19, 1867; Thomas Affleck to Alexander Hannay, July 14, 1865, Affleck papers. For examples of stories purported to show Negro "inferiority," see John J. Linn, Reminiscences of Fifty Years in Texas (New York, 1883), 357-60; W. A. Carter, History of Fannin County, Texas: History, Statistics, and Biographies (Bonham, Texas, 1885), 56-57. 
labor. In the same order that had freed the slaves, General Granger had warned the blacks against gathering "at military posts" and informed them "that they will not be supported in idleness either there or elsewhere." Granger asked the freedmen to "remain quietly at their present homes and work for wages." The Negroes, however, had different ideas. They left the plantations and took to the roads, wandering aimlessly, congregating at Army camps and in cities. Some of those brought into Texas during the war set out for their old homes in Louisiana and Arkansas. Negroes with cruel masters took the opportunity to flee the lash. Black artisans moved to the cities to look for work. Others left for strange places to start a new life without the painful memories of a past bondage continually staring them in the face. For these people, it was easier to feel free if they did not have to feel obliged to habitually say "Mastah" and "Missus" each day, but most merely wished to test their freedom and to have the joyful experience of going where they pleased without restriction. 27 Those Negroes who returned or stayed at home showed a great reluctance to sign labor contracts. They preferred to wait for the promised forty acres and a mule which they expected would be give at Christmas 1865. The Army did its best to discourage this expectation, but to no avail. ${ }^{28}$ As Christmas approached, worried whites began to

27 Ramsdel1, Reconstruction in Texas, 49-50; Bancroft, History of the North Mexican States and Texas, II, 480; Cox, "Economic History of Texas," 29, 41; Hayman, "A Short History of the Negro of Walker County," 14-15; Seth Shepard McKay, "Texas Under the Regime of E. J. Davis" (Unpublished M.A. thesis, University of Texas, Austin, 1919), 57; Speer, History of Blanco County, 38.

$28_{\text {The }}$ "forty acres and a mule" had real potential with Texas Negroes. They may have learned that Senator James H. Lane of Kansas had introduced a bill in 1863 to grant the state's lands between the 
fear that disappointed freedmen might forcefully divide up their plantations when they discovered the forty acres were not forthcoming. To be prepared for any contingency, the planters organized a temporary police force. 29 The Negroes' idleness and reluctance to sign contracts had led the planters to concoct a scheme to introduce immigrants into the state to replace the black laborers. The Texas Land, Labor, and Immigration Company sent Thomas Affleck to Europe to induce settlers to come to the state. The project failed, however, because Europeans hesitated to come to the politically unstable South; moreover, the planters slowly became aware that Negro labor would be practicable under free conditions. 30

Colorado and the Rio Grande to black settlers. See Congressional

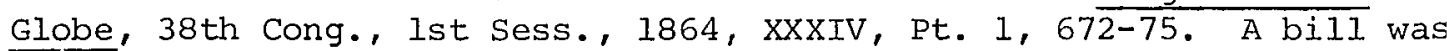
passed to grant forty acre allotments to Negroes from abandoned lands in 1864. Such plots were granted to blacks on the South Carolina sea Islands, and Maj. Gen. W. T. Sherman's famous GO 15 gave all lands within thirty miles of the coast to freedmen, but all of these grants were later negated by the government. See La Wanda Cox, "The Promise of Itand for the Freedmen," Mississippi Valley Historical Review, XLV (1958), 413-40. See also, Hamilton to President Johnson, October 21, 1865, Johnson papers; Ramsde11, Reconstruction in Texas, 71-72; Cox, "Economic History of Texas," 35. Gregory tried to discourage Negro hopes for land. See Circ. 1, October 12, 1865, Texas Freedmen's Bureau.

29 J. O. Thilly to Hamilton, November 6, 1865, A. P. McCormick to Hamilton, November 13, 1865, Charles B. Stewart to Hamilton, November 27, 1865, Citizens of Liberty County to Hamilton, November --, 1865, W. B. Price to Hamilton, December 23, 1865, Governor's papers (Hamilton).

30 Although the whites feared the Negro would not work unless compelled, crop production rose steadily during Reconstruction, in spite of black migration to the cities. See Cox, "Economic History of Texas," 4, 28, 46. See also, Bentley, History of the Freedmen's Bureau, 82; John William Rogers, The Lusty Texans of Dallas (New York, 1951), 101-103; Bowles, "History of Trinity County," 51 . Lowman, "The Cotton Industry in Texas During the Reconstruction Period," 73, feels the reliability of Negro labor, the increased industriousness of the white man who was now freed of the onus slavery cast on physical labor, and immigration between 1866 and 1880 are what kept crop production rising in the state. On immigration efforts and their general failure, 
The most controversial attempt to facilitate the use of former slaves as free laborers came in the fall of 1866 when the Eleventh Jegislature passed a series of measures collectively known as the "Black Codes." The Army played a conservative role once again by allowing all of the acts to stand except one. ${ }^{31}$ Because Texas had been late in reorganizing its government after the war, she had the benefit of northern criticism leveled at Black Codes passed by the other southern states. In many cases she used this to her own advantage by enacting Army orders as state laws. The state act "to provide for the punishment of persons tampering with, persuading or enticing away . . laborers or apprentices under contract . . " was quite similar to Freedmen's Bureau Circular No. 14, of May 15, 1866. The Texas law stated that anyone "who shall persuade, or entice away from the service of an employer, any person who is under a contract of labor to such an employer" was liable to be punishea by a fine or imprisonment in the county jail or both. Any person who employed a laborer before his contract to another employer had expired would receive similar punishment. To protect an apprentice's rights, an employer who discharged him had to pay a fine unless he gave the apprentice a written certificate of discharge to enable him to find a new position. Circular No. 14, did not go into as much detail but it did provide that those who enticed away a laborer or apprentice under contract

see Cole, "The Texas Career of Thomas Affleck," 227-446, passim. Most of the newcomers to Texas probably came from other southern states. See Houston Telegraph, January $4,1870$.

${ }^{31}$ Sefton, United States Army and Reconstruction, 42-43; Theodore $B$. Wilson, The Black Codes of the South (University, Alabama, 1965), 57-60; Joe M. Richardson, "Florj.da Black. Codes," Florida Historical Quarterly, XLVII (1968-69), 369-70. 
would suffer a fine. In addition, the Bureau circular provided that the laborer who allowed himself to be enticed away could be fined with the amount being withheld from his wages. 32

The Army also helped entrench the lien and share-cropping system in agriculture. General Gregory ordered any labor contract to constitute a lien on the crop in the fall of 1865. The state legislature passed a lien law one year later providing that any provisions, tools, stock, or cash advanced to make a crop constituted a lien on that crop. The lien had preference to any other debts that might be contracted except the rent of the land. Two months later, in December 1866, the Bureau issued Circular No. 25 which ordered agents to recommend that Negroes work for a share of the crop rather than wages. With the Bureau's approval, the lien and share-cropping were well established in the state by 1869, and the Negro was doomed to be a tenant at the mercy of $h$ is economic betters. 33

For these reasons, the Army acquiesced in a strict vagrancy law designed to make plantation work more attractive than idleness to the freedmen. The act defined a vagrant as any "idle person, living without any means of support, and making no exertions to obtain a live-

32 H. N. P. Gammel (comp.), The Laws of Texas, 1822-1897 (10 vols., Austin, 1898), V, 998-99; Circ. 14, May 15, 1866, Texas Freedmen's Bureau. Circ. 17, June 19, 1866, ibid., ordered Bureau agents to read Circ. 14 to the Negroes in their area and see to it that the circular was strictly enforced. For the "general apprentice law" which had similar penalties, see Gammel, Laws of Texas, V, 979-81. Certain rights were given to Negroes (the right to sue, "to have and enjoy the rights of personal security, liberty, and private property"), and certain slave codes were repealed at the same legislative session. Ibid., 976, 1049-50.

${ }^{33}$ Gamme 1, Laws of Texas, V, 982; Circ. 25, December 21, 1866, Texas Freedmen's Bureau; Cox, "Economic History of Texas," 41. 
lihood, by any honest employment." Included in this definition were gamblers, prostitutes, habitual drunkards, "or persons who stroll idly about in the streets of towns or cities, having no local habitation, and no honest business or employment . . . " Such persons, when convicted, could be fined and put to labor on public works until their debts were paid off. Those who refused to work for the municipality could be lodged in the town jail and live on bread and water until they changed their minds. Their sentences would not begin until such time as they began to work them off. The Freedmen's Bureau believed that vagrancy laws were a valid means of dealing with Negroes who refused to sign labor contracts, as long as the laws were applied equally to whites and blacks. General Gregory was very strict in this matter and he defined any black away from his employer more than one day "without a just cause" a vagrant. 34

The Army, however, had grave doubt.s about the November 1 law, "An Act Regulating Contracts for Labor." Unlike the other laws, the military believed this measure obviously applied only to the freedmen. ${ }^{35}$ Parts of the act followed earlier Freedmen's Bureau directives.

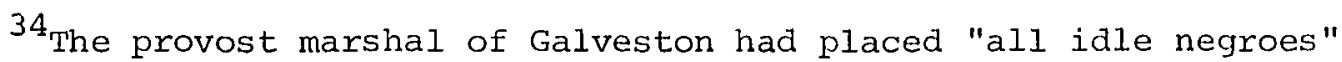
to work on city streets within two weeks of the Army's arrival, Galveston Daily News, June 28, 1865. See also, Gammel, Laws of Texas, V, 1020-22; Circular Letter, October 17, 1865, Gregory to Benjamin G. Harris, August 20, 1866, Letters Sent, Texas Freedmen's Bureau records. Local communities followed the state legislature's lead and also established strict vagrancy laws. See Tausch, "Southern Sentiment Among the Texas Germans," 81; Dudley Richard Dobie, "History of Hays County, Texas" (Unpublished M.A. thesis, University of Texas, Austin, 1932), 77.

${ }^{35}$ Cole, "The Texas Career of Thomas Affleck," 360-61, maintains that the labor laws were introduced by the same men interested in attracting white immigrant laborers to the state. These laws were designed to safeguard the employer's rights when these laborers arrived. Cole feels the laws received little opposition because it was recognized they could be used against Negro labor, but that this 
Contracts binding on all family members were made with heads of families; they were to be written out in triplicate with copies for the employer, the laborer, and the county records; they constituted a lien on the crop; and the employee could not leave his place of work without his employer's permission. ${ }^{36}$ Other sections of the act, however, hinted at a re-enslavement of the colored laborers. If the laborer feigned sickness, an amount equal to double his wages could be deducted for the lost time. Any disobedience by the laborer incurred a fine for each offense. Losses due to theft were to be restored to the employer at double their value. Most importantly, the employer was allowed to assess these fines himself although the laborer then had the right to appeal to the nearest justice of the peace. Another especially offensive demand was that laborers be on call twenty-four hours each day with the stipulation that "it is the duty of this class of laborers to be especially civil and polite to their employer, his family and guests. . . " 37

General Kiddoo disliked the discriminatory sections of the labor act, and on January 3, 1867, he ordered that it be disregarded

was a secondary consideration. The act's sponsors believed free black labor would never be successful and were looking for a practical alternative. Cole's thesis contradicts Ramsdell, Reconstruction in Texas, 125, and Du Bois, Black Reconstruction, 143.

${ }^{36}$ The law is in Gammel, Laws of Texas, $V, 994-97$. Similar statements by the Bureau are in Circular Letter, October 17, 1865, Letters Sent, Texas Freedmen's Bureau records.

${ }^{37}$ Gammel, Laws of Texas, V, 994-97. Ramsdell, Reconstruction in Texas, 122, sees the Black Codes as an honest attempt by the legislature to provide the "constant watchfulness and semi-coercion" the Bureau used to keep the Negroes at work by providing "a system of regulation more permanent than that of the Bureau professed to be." The labor act went considerably further, however, than the Bureau directives. See also, ibid., 120-21, 125-26. 
by state courts. There evidently was some problem in forcing the state courts to ignore the labor law because General Griffin had to reissue the order seven months later. By January 1868, however, General Hancock's policy of relying on civil authorities to enforce the laws had severely undercut the Bureau's ability to regulate labor contracts. Once again, the Army had acted to preserve planter control of Negro labor. ${ }^{38}$ In spite of the Army's conservative role on the labor problem, its very presence as a third force in the state was resented by the planters. Thomas Affleck wanted to draw up a fiveyear contract with his Negroes but feared the Army would not allow it. "Yankee-like, they will not give up their assured right (the right of might) to interfere between me \& the negroes at all times," wrote Affleck, "and that, after a contract is made, I will not tolerate."39 The history of the Negro in Texas Reconstruction is the tale of how a defeated state achieved the principles for which it had seceded from the Union. "We hold as undeniable truths that the governments of the various states, and of the confederacy [the United States] itself, were established exclusively by the white race, for

38 There seemed to be some confusion as to just when the act took effect. See San Antonio Ledger, November 9, 1866. For the orders cancelling the law, see GO 2, January 3, 1867, Go 25, August 3, 1867, Texas Freedmen's Bureau. See also, A. H. Moore to AAG, January 25, 1868, Letters Received, Civil Affairs, Fifth Military District records. An interesting sidelight occurred when the Black Codes were nullified. The fines were to have gone into a fund to care for pauper children. No further provision had been made by the state legislature for the children which left them wards of the counties. The local governments were slow to help these indigent children, especially if they were black. See Capt. Charles F. Rand to AAG, February 11, 1867, "Transcript of Records, 1838-1869"; Throckmorton to Griffin, March 4, 1867, Throckmorton papers; Throckmorton to Harris County Judge, March 4, 1867, Executive Correspondence.

${ }^{39}$ Affleck to Hannay, July 14, 1865, Affleck papers. 
themselves and their posterity," declared the secession document, "that the African race had no agency in their establishment . . . and can only exist as an inferior and dependent race." The declaration continued, "that in this free government, ALL WHITE MEN ARE AND OF RIGHT OUGHT TO BE, ENTITLED TO EQUAL CIVIL AND POLITICAL RIGHTS . . . " The Army acquiesced in these principles more than the epithet "Military Rule" might suggest. 40

${ }^{40}$ Quoted in Wortham, A History of Texas, IV, 391-97, especially 396. For the early adoption of white supremacy by Texans, see also, Barry A. Crouch and L. J. Schultz, "Crisis in Color: Racial Separation in Texas During Reconstruction," Civil War History, XVI (1970), 37-49. 


\section{IACKING WATER AND GOOD SOCIETY}

A native Texan once apologetically told Senator Benjamin Wade of Ohio that all Texas needed to make it a paradise was water and good society. Wade supposedly replied with a laugh, "that's all they need in hell!" Ben Wade was not alone in his feelings because comparing Texas with hell was a national pasttime during the postwar years. "I am not much given to profanity," wrote one county judge to Governor A. J. Hamilton, "and you must know the intensity of my feeling when I say that I had as soon be in Hell as Texas." Even General Phil Sheridan allegedly made the usual analogy during an inspection of the District of Texas. The general observed that if he owned both Texas and hell, he would rent out Texas and live in hell. A local wag reportedly countered that he always admired a man who would stand up for his home country; but conditions in Reconstruction Texas gave alarming verity to Little Phil's preference. ${ }^{1}$

The Civil war had left behind social debris in place of organized society, and most white Texans believed that the Federal government's Reconstruction policy threatened to destroy what remained of self respect, decorum, and morals. As early as May 1864 Governor

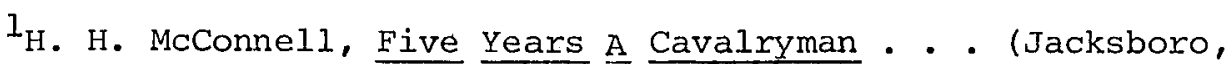
Texas, 1889), $214 \mathrm{n}$.; Barkley, History of Travis County and Austin, 101; Rupert N. Richardson, et al., Frontier Forts of Texas (Waco, 1966), 63; Du Bois, Black Reconstruction, 677; C. Caldwell to Gov. A. J. Hamilton, January 23,1867 , Hamilton papers. 
Pendleton Murrah protested that the "rule of the mob, the bandit, of unbridled passions rides over the solemn ordinance of the government." The anarchy of the final war years continued long after the surrender. At times it seemed as if every man in the state was trying to shoot, hang, maim, or rob everyone else. Border areas held so many fugitives from the law that the Nueces River became known as "the deadline for Sheriffs." The ex-Confederates, the Unionists, and the Negroes refused to cooperate to preserve the peace. Hence the ordinary forces of social control broke down and left each individual to protect himself. Murder became so common that people ceased to think of it as crime, and much of the public indifference to the Army's peace-keeping role must be seen in this light. ${ }^{2}$

Northern observers in the state after the war were shocked at the "go-as-you-please" attitude of Texans toward law and order, as Elizabeth Custer phrased it. Visitors were amazed at the numerous persons armed with shotguns, rifles, revol.vers, and knives which were

${ }^{2}$ Ramsdell, Reconstruction in Texas, 23; Reese, "History of Hill County," 147; Curtis, "History of Gillespie County," 67; Dobie, "History of Hays County," 77; W. C. Holden, "Law and Lawlessness on the Texas Frontier, 1875-1890," Southwestern Historical Quarterly, LXIV (1940-41), 202-203; Wallace, Texas in Turmoil, 145; Bancroft, History of the North Mexican States and Texas, II, 473, 499; Nunn, Texas Under the Carpetbaggers, 4-5, 245-46; Pool, "History of Bosque County," 92; Chester P. Mysilwiec, "A History of Karnes County, Texas" (Unpublished M.A. thesis, University of Texas, Austin, 1952), 66; Oreta Turner, "Border Troubles Along the Rio Grande From 1848-1878" (Unpublished M.A. thesis, East Texas State University, Commerce, 1940), 12, 14; J. Frank Dobie, A Vaquero of the Brush Country (Boston,

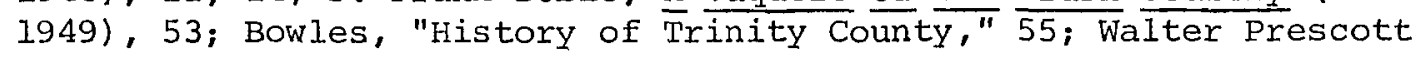
Webb, The Texas Rangers: A Century of Frontier Defense (Austin, 1965,

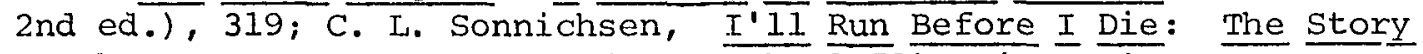

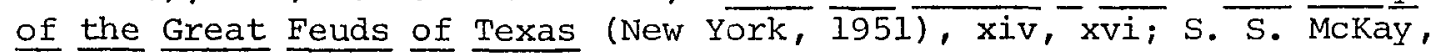
"Social Conditions in Texas in the 1870's," West Texas Historical Association, Year Book, XIV (1938), 44-45. 
poorly concealed under their "humped-up coats." Not only were Texans well armed, they knew how to use these weapons and did so with little provocation. The number of armed men with a "reckless dare-devil look" that roamed Brenham's streets horrified Thomas North, a Yankee dry goods dealer. North believed "the standard of moral sentiment with the public in gross is lower in Texas than elsewhere in the South," and he attributed this to the "pioneer life" conditions in the state. Even the battle-hardened veterans of the Seventh Indiana Cavalry were overawed by what they saw. "I can say this of Texas generally," recorded their historian, "it is a very mean state." Benjamin Truman told the United States Senate that Texas had never had any law to speak of and he asserted that the state averaged 450 murders a year before the Civil War. ${ }^{3}$

Texans vehemently protested that the lawless picture of their state was exaggerated beyond just proportions. "At the time . . every person now living in Texas, who was old enough to remember the facts," reminisced one authority, "knows that.. . law and order prevailed; that there was no disturbance, except what was created by Indians and a few desperadoes on the frontier...." This same Texan claimed "there was no resistance to Federal law or opposition to Federal authority" and he believed "that life and property were as safe in Texas" during Reconstruction "as they were before the commencement of the Civil War ... ." Texas newspapers insisted that the

3 McConnel1, Five Years A Cavalryman, 44; Custer, Tenting on the plains, 218, 223, 225, 241-42, 260; North, Five Years in Texas, 68, 104-105; Cogley, Seventh Indiana Cavalry, 172; "Truman Report," Senate Executive Documents, 39th Cong., 1st Sess., No. 43, 11. 
Radical Republicans had to overemphasize what lawlessness there was in order to justify the Reconstruction Acts of 1867. The Denton Monitor even called the Ku Klux Klan a "radical trick" and claimed the Klan was run by the Union Loyal League. The Brownsville Daily Ranchexo attacked southern Republican newspapers, which "are intended to make black white and white black for the eyes of the northern reader -. . May they succeed," snapped the Ranchero, "and the country go straight to hell!" In Galveston the Daily News remarked that the frequent lawless acts in the North were inadequately reported and complained that "we do not hear anything about declaring martial rule there on account of the lack of 'adequate protection of life and property. " "4

The reputation Texas had for lawlessness and disorder undoubtedly owed much to the nation's picture of what life in Texas was like. Texans were thought of as great fighters; big men, with hard fists, and quick guns. Robert E. Lee considered the Texas Brigade his prime shock troops, able to accomplish the impossible when all others had failed. Texas stories and legends were big business, and the literature of the period abounded with tales of violence about the land west of the Sabine River. When Yankee visitors imbued with stories of Texas adventure axrived in the state, they looked for verifying evidence and often exaggerated minor incidents. But all legends are based on some fact, and Texas did have more than its share of lawlessness and violence after the war's end. 5

${ }^{4}$ William D. Wood, Reminiscences of Reconstruction in Texas, 7-8; Denton Monitor, May 30, September 5, 1868; Brownsville Daily Ranchero, May 15, 1867; Galveston Daily News, March 9, 1867.

${ }^{5}$ Llerena B. Friend, "The Texan of 1860," Southwestern Historical 
Many of the crimes committed in Texas had racial overtones. The problem was caused, in part, by the difficulty of convincing whites that they could no longer punish Negroes summarily. Thomas Affleck, an affluent planter who lived near Brenham, wrote of the anguish he went through trying to live under the new system. When several of his field hands "grossly insulted my wife," Affleck confessed "to be under such a degree of excitement that I dare not trust myself to deal with them." Affleck sent a loyal Negro to town to bring out the local Freedmen's Bureau agent, "the officer in command of this class of people," to solve the problem. ${ }^{6}$

Other whites, however, were not as circumspect as Affleck and preferred to take Negro discipline into their own hands. Planters regularly administered whippings to Negroes for theft or minor irritants such as not prefacing a white man's name with "Mas." Freedmen were run out of town by groups of horsemen or prankishly shot at by town loafers. One Texas white was arrested and tried in a military court for shooting a Negro with small bird shot. The defendant received six months at hard labor on Ship Island, Mississippi. General Sheridan was especially incensed at the Texan's motive--"the object being not to kill . . but to punish severely." If blacks reported the incidents to the Army, the area would become mysteriously quiet

\footnotetext{
quarterly, LXII (1958-59), 1-17; James Seborn Scaief, "Texas in National Periodical Literature, 1865-1885" (Unpublished M.A. thesis, University of Texas, Austin, 1943), 60, 118, 143, 144; J. C. Dykes, "Dime Novel Texas: Or, The Sub-1iterature of the Lone Star State," Southwestern Historical Quarterly, XIIX (1945-46), 327, 329.

6 Thomas Affleck to Lt. B. I. Arnold, November 12, 1865, Affleck papers, emphasis in the original.
} 
while the soldiers made their investigations. When the troopers moved on to examine new outbreaks miles away, the shootings and whippings would begin anew in the area they had just left. Masked men warned Negroes that the Army could not remain their protector forever, and that sooner or later the whites would have their revenge. Those few white men who were caught beating Negroes were generally tried by state courts for simple assault and released with a small fine. One defendant escaped with a ten dollar fine for beating up a Negro with an oxbow. Most soldiers felt the blacks were worse off after emancipation than before when they at least had an economic value which provided some protection from atrocities. 7

There was little paternal protection available to Texas Negroes during Reconstruction. Cabins on the big plantations were visited by individuals and groups who murdered, assaulted, robbed, and burned at will. Planters who were too cooperative with the military authorities were warned not to interfere when their white neighbors drove off their field hands with threats and intimidations. ${ }^{8}$ In an extremely

7 These and similar incidents are described in William B. Dewees to A. J. Hamilton, - 1865, J. C. McAlpine to Hamilton, September 4, 1865, W. Longworth to Hamilton, October 9, 1865, D. J. Baldwin to Hamilton, November 7, 1865, Governor's papers (Hamilton). See also, W. G. Phillips to Throckmorton, December 14, 1866, Byron Porter to Bvt. Lt. Col. H. A. Ellis, December 18, 1866, ibid. (Throckmorton); B. F. Barkley to A. Wright, June 25, 1868, ibid. (Pease); Capt. Gaza Harazthy to AAAG, April 13, 1866, Capt. Harlan P. Spalding to AAAG, April 26, 1866, House Executive Documents, 40th Cong., 2nd sess., No. 57, 111, 113; Wright to AAG July 21, 1866, House Reports, 39 th Cong., 2nd Sess., No. 61, 1-4; Throckmorton to Griffin, Apri1 6, 186\%, Throckmorton papers; Sheridan to Grant, May 10, 1867, Grant papers; Lt. J. M. Beebe to $A A G$, May 26, 1866, Letters Received, District of: Texas records; CO, Post of Austin to AAG, July 5, 1869, Letters Received, Civil Affairs, Fifth Military District records.

${ }^{8}$ Statement of 'Thomas Holliman, February 25,1867 , and $\mathrm{l}$. W. Reinhard to AAG, February 18, 1867, in "Transcript of Records, 14331869"; Second Lt. C. G. Gordon to AAG, March 12, 1868, Governor':; 
brutal case, three Waco men were charged with castrating a Negro boy.

In spite of protestations by local citizens and Governor Throckmorton, the Army held the men without bail although they were later released to state authorities for trial. 9

Violence was common when Negroes were accused of serious criminal activity, and few blacks arrested for rape or murder came to trial. A black accused of murdering a former Confederate soldier was shot in front of the San Marcos jail by a mob which ordered the sheriff to step aside to give them a clear field of fire. In Georgetown a local man whose wife had been raped shot the Negro suspect in his jail cell. In northern Texas, a more enterprising husband produced a letter supposedly signed by none other than Brigadier General J. B. Kiddoo, head of the state's Freedmen's Bureau. The letter gave the man custody of the suspected black rapist who was eventually killed. It is noteworthy that Bell County handed out the first hanging penalty of its history after the Civil War to a Negro defendant. ${ }^{\circ}$ Another frequent cause of crime in Texas was the clandestine activity of the Ku Klux Klan. Colonel Roger Q. Mills was believed to

papers (Pease); Richard Kimball to AAG, February 7, 1869, Letters Received, Fifth Military District records.

9 Lt. A. F. Manning to Kiddoo, January 20, 1867, and Messrs. Flint and Chamberlain to Throckmorton, January 22, 1867, both in "Transcript of Records, 1838-1869"; Throckmorton to B. H. Epperson, January 29, 1867, Governor's Correspondence; Throckmorton to Griffin, January 28, 31, 1867, Throckmorton papers; AAAG to Lt. A. F. Manning, February 5, 7, 1867, Letters Sent, Texas Freedmen's Bureau records.

10 Bowles, "History of Trinity County," 56; Dobie, "History of Hays County," 78; Throckmorton to Kiddoo, August 30, 1866, Throckmorton papers; Georgetown Watchman, March 20, 27, 1869; Atkinson, "History of Bell County," 133; William Samuel Mills, History of Van Zandt County (Canton, Texas, 1950), 235-36. 
head the organization, but the various terrorist groups seemed to operate more on a local level with no central direction. The Klan operated to fill the vacuum left by the disappearance of the old slave patrols and punished Negroes for many of the same "crimes," such as being out after curfew hours or acting "uppity." Besides the Ku Klux Klan, other bands known as Pale Faces, Knights of the White Camellia, White Brotherhood, or the Constitutional Union Guards operated in eastern Texas. 11

White Texans considered the Klan to be their "savior from evil and oppression" and thought that no other method "could have lifted us so easily and completely in so short a time." The movement was supposedly composed of citizens of high standing and local law enforcement personnel who, "by vigorous but cautious action," re-established "the proper relationship between the white race and the negro element." The myth asserted that little or no bloodshed or violence accompanied the Klan's activities and that its record read "more like a fairy tale than sober reality."12 But the United States Senate believed that the main problem in securing law and order in the southern states came from Ku Klux threats, and even contemporaries expressed some doubt as

${ }^{11}$ Susan Lawrence Davis, Authentic History: Ku Klux Klan, 18651877 (New York, 1924), 254; Stanley F. Horn, Invisible Empire: The Story of the Ku Klux Klan, 1866-1871 (Boston, 1939), 284-85; Brown, History of Texas, II, 634-35, 639-40; Nunn, Texas Under the Carpetbaggers, $247-49 ;$ William D. Wood, "The Ku Klux Klan," The Quarterly of the Texas State Historical Association, IX (1905-1906), 262-68.

${ }^{12}$ Charles H. Moore, "Anderson County During Reconstruction," (Unpublished Manuscript in the Charles H. Moore papers, Archives, University of Texas), 6; Wood, "Ku Klux Klan," 266; Barbara Susan Overton Chandler, "A History of Bowie County" (Unpublished M.A. thesis, University of Texas, Austin, 1937), 50; Mooxe, "The Life of John Benjamin Long," 53-54. 
to the sterling character of the Klansmen. The Sulphur Springs Klan found it could not control its hotbloods who insisted on violence to back up the group's veiled threats against Negroes in Hopkins County. The cooler minds disliked violence because it attracted Federal military patrols to an area. ${ }^{13}$

Klan activities ranged from murdering the Goliad sheriff because he "favored" Negroes to whipping two men in Bell County who belonged to an odd religious sect and another man who asserted he had no religion at all. In Matagorda County, the local Klansmen deposited their arms at J. C. McNeill's house and were issued ammunition by McNeill's wife and children when he was absent on business. A similar tactic was used in San Augustine where a Negro, Henry Garrett, organized a militia company that drilled near a fortified house. The whites of the area also organized and visited individual Negro militiamen at night to administer them a "good flogging." When the whites felt strong enough and Army patrols were not in the area, they attacked and subdued the Negro fort. Nightly raids continued on isolated Negro homes until the blacks were "inspired . . with a wholesome respect for the white population," and "encouraged to vecome useful citizens." In Hallettsville a band of masked men tried to force their way into

13 Major Guy M. Bryan wrote Rutherford B. Hayes, a personal friend, that the Klan tales were completely false and no such organization existed in Texas. Bryan wanted Texas eliminated by name from a congressional investigation report but he failed to persuade Hayes. See Bryan to Hayes, August 29, 1871, in E. W. Winkler (ed.), "BryanHayes Correspondence," Southwestern Historical Quarterly, XXVI (1922-23), 60-62. See also, Senate Reports, 42nd Cong., 2nd Sess., No. 41, Pt. 1, 2; James Lee Martin, "History of Goliad, 1836-1880" (Unpublished M.A. thesis, University of Texas, Austin, 1937), 134; Gladys Annelle St. Clair, "A History of Hopkins County, Texas" (Unpublished M.A. thesis, University of Texas, Austin, 1940), 69. 
the home of Jacob Oakman, a Negro. When Oakman successfully prevented their entrance, the interlopers fired shots into his home from all directions. The raiders returned again a week later with the same results. In Brenham a party of men rode about shooting at Negroes, hogs, dogs, and houses, creating much anxiety among the local blacks. Whites who attempted to organize Negroes politically were a favorite target of Ku Klux groups. In Trinity County the church housing one such meeting was fired on by unknown assailants, while in Belton a scalawag who had talked to Negroes was ducked in a nearby creek. Belton's cellars were regularly used as places of punishment for recalcitrant blacks and theix white allies. 14

The Army tried unsuccessfully to halt these raiders. Their identity was well-concealed by hoods and masks, and their victims were unable or unwilling to identify them. Headquarters ordered soldiers to arrest anyone wearing a disguise or a mask. Troop commanders were to hold such suspects indefinitely. The arrested men were sent from post to post in the area in order to find witnesses who would identify

\footnotetext{
14 Martin, "History of Goliad," 133; Atkinson, "History of Bell County," 129-30, 142, 148; John Columbus Marr, "The History of Matagorda County, Texas" (Unpublished M.A. thesis, University of Texas, Austin, 1928), 165; George Louis Crocket, Two Centuries in East Texas: A History of San Augustine County and the Surrounding Territory From 1685 to the present Time (Dallas, 1932), 347-49; Judge A. K. Foster to AAG, February $6, \frac{1869}{186}$ Letters Received, Fifth Military District records; Bowles, "History of Trinity County," 57. There were several areas that, for various reasons, experienced few racial problems. See Real, "History of Kerr County," 50. Boden, "History of Burnet County," 76; Curtis, "A History of Gillespie County," 68; Memorial and Biographical History of Navarro, Henderson, Anderson, Limestone, Freestone, and Leon Counties (Chicago, 1893), 260; Hayman, "A Short History of

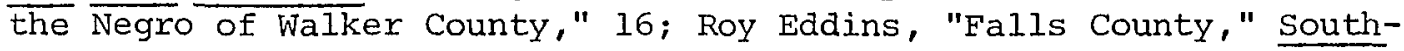
western Historical Quarterly, LIV (1950-51), 225; St. Clair, "History of Hopkins County," 68 .
} 
them as Klansmen but to no avail. An exasperated General Reynolds informed Washington that civil law was dead east of the Trinity River. Law officers were Klan leaders, victims were regularly announced at public meetings, and the number of Negroes murdered was so high as to defy an accurate body count, said Reynolds. Federal soldiers sent to restore order were also frequently murdered. ${ }^{15}$

The Klan was not the only agent disrupting law and order in Texas. Bands of guerrillas and brigands abounded along the Red River and the dense woods in eastern Texas known as the "Big Thicket." These outlaw groups posed a grave threat to the Army for they seldom hesitated to ambush troop detachments or lightly guarded supply wagons. The Big Thicket and the Red River bottom had long been a no man's land in Texas, and even before the war the area abounded with murderexs, feuding gangs, horse thieves, slave stealers, and assorted toughs hiding from the law. These marauders were organized by a local sheriff or judge who could offer immunity from prosecution. 16

The Civil War brought a new notoriety to the wilds of eastern Texas because Confederate deserters and draft dodgers also fled to the

${ }^{15}$ See GO 15, October 12, 1868, Printed Orders, Fifth Military District; B. W. Musgrove to AAG, July 20, 1868, Letters Received, District of Texas records; Reynolds to AGO, USA, October 22, November 4, 1868, Letters Sent, Fifth Military District records; St. Clair, "History of Hopkins County," 69.

${ }^{16}$ Sonnichsen, I'll Run Before I Die, 4-5. In addition to the outlaws, feuds also plagued Texans for years. The Regulator-Moderator war left many ill-feelings in eastern Texas during the 1840's, drove settlers from the area, and attracted brigands. John Warren Love, "The Regulator-Moderator Movement in Shelby County" (Unpublished M.A. thesis, University of Texas, Austin, 1936), 10-11. The Taylor-Sutton feud, fought in and around De witt County after the war, was put down by the Army in 1868. See Huson, Refugio, I, 128. 
area. These deserters increased the ranks of the outlaws greatly and they fought many successful battles with Confederate and state troops sent to subdue them. As the war drew to a close, die-hard Confederates who had failed to reach Mexico drifted into the woods, again providing a rich source of recruits for the brigands. ${ }^{17}$ By the summer of 1865 , the number of marauders in Texas had reached an all time high, and the Army had declared these men to be guerrillas, an offense punishable by death. ${ }^{18}$ In response to several requests from Governor Hamilton, General Custer sent numerous cavalry patrols into northeastern Texas to quell the desperadoes with little real success. When the regular cavalry arrived in late 1865, Generaj. Wright recommended that small posts be set up at key points in the area to stop further raids. But the bandits had already learned that a half dozen armed men could easily terrorize a town and that the soldiers could not be everywhere at once. 19

Cullen Baker, Benjamin F. Bickerstaff, and Bob Lee led the major outlaw gangs that pillaged northeastern Texas. Baker, "The Swamp Fox

17For Civil War incidents, see Anne Ethel Cassles, "A History of Hunt County" (Unpublished M.A. thesis, University of Texas, Austin, 1935), 54-55; Heintzen, "Fredericksburg in Civil War and Reconstruction," 77-78; Charles Adelbert Herff, "A Forward or Forerunner" (Typescript in Charles A. Herff papers, Archives, University of Texas), 25-26; North, Five Years in Texas, 68-69; Brig. Gen. E. B. Brown to AAAG, June 2, 1865, Sheridan papers; San Antonio News, May 30, 1865.

18 Flake's Daily Bulletin (Galveston), July 10, 1865; Bellville Countryman, July 15, 1865; AAG to Maj. Gen. T. J. Wood, August 6, 1865, in $\underline{0} . \underline{R}_{.}, \mathrm{XLVIII}$, Pt. 2, 1169-70.

19 Hamilton to Custer, November 21, 1865, Governor's Correspondence; Custer to Hamilton, November 23, 1865, Governor's papers (Hamilton); Wright to AAG, March 2, 1866, Sheridan papers; Hamilton to Johnson, March 1, 1866, Johnson papers; "Truman Report," Senate Executive Documents, 39th Cong., lst Sess., No. 43, 13. 
of the sulphur," was typical of the bandit chieftains. He had a record of murder before the war and had joined the Confederate army only to desert in 1863 to the safety of the swamps east of Sulphur springs. Here he began his career of plunder which was spiced by numerous killings of Negroes and Freedmen's Bureau agents--a Baker specialty. Baker liberally referred to anyone who opposed him as an "abolitionist" who was marked for death. Soon his name was on the lips of everyone in the region because of his natural talent for making fools out of the soldiers sent to capture him. He rode singlehandedly up to one patrol, introduced himself, and would have shot the lieutenant in command had his revolver not misfired. Another time, the lone Baker was credited with chasing a patrol into Boston, Texas, and then audaciously demanding that the twenty soldiers surrender to him. Baker ran an outlaw's "school" in the swamp where he taught his recruits the fine points of using a six-shooter and the virtues of shooting all prisoners or wounded soldiers in the head. He regularly ambushed the columns sent for him in the dense swamplands. If the Army made things too risky in Texas, Baker would slip across the border to Indian Territory or Arkansas until the situation quieted. Then he would return and begin his raiding all over again. 20

${ }^{20} \mathrm{Cullen}$ Baker's legend is found in R. H. Watlington, "Memoirs" (Typescript in R. H. Watlington papers, Archives, University of Texas), 72-73, 84-85; Ed Bartholomew, Cullen Baker: Premier Texas Gunfighter (Houston, 1954), 26-27, 42, 43, 50-54, 61, 63, 76. Bartholomew also includes Thomas Orr's, Life of the Notorious Desperado, Cullen Baker - . as an appendix to his work $(86-132)$. Orr was the Unionist who killed Baker. Bartholomew subscribes to theory that the evils of Reconstruction made Baker an outlaw and he tends to picture him as a hero $(50-51,84)$. For the murder of Bvt. Capt. W. G. Kirkham, Freedmen's Bureau agent, see Denton Monitor, November 7, 1868. 
Because of his antics with the Army, his raiding of Army wagons, and his clever rationalizations of his thievery as loyal southern acts, Baker became a kind of Robin Hood in northeastern Texas. He achieved this in spite of his frequent murders of Texans who dared to associate his name with any crime whatsoever. Finally, however, Baker's psychotic drive to kill became obvious even to the most ardent Confederate flag wavers. It was evident that Texans were afraid of him and had rationalized their losses as aid to a persecuted son of the South, just as Baker had hoped they would. On January 6, 1869, one of Baker's "abolitionist" enemies, Thomas Orr, rounded up a half dozen friends and gunned Bakex down. 21

Bickerstaff and Lee were both shot by troopers of the Sixth Cavalry within three months after Baker's death. Like Baker, they had made a career of bushwacking soldiers and stealing Army supplies. Bickerstaff's gang controlled the Sulphur springs area so well that the local Army garrison lived in a state of siege. In September 1868 headquarters sent Captains A. R. Chaffee and T. W. Tolman with two companies of the Sixth Cavalry to Sulphur Springs to destroy the outlaws. While Tolman secured the town, Chaffee hounded the Bickerstaff gang across northern Texas. His merciless tactics and his harsh treatment of civilians who aided the thieves earned his unit the name of "Chaffee's Guerrillas," but he produced results. Several of the

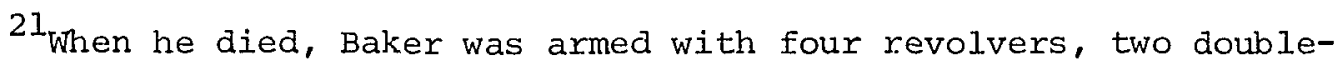
barreled shotguns, three derringers, and six knives. Bartholomew, Cullen Baker, 82-84. Bartholomew feels Baker was shot only because he was drunk or asleep. He ignores the fact that Baker had finally overstepped his bounds when he tried to kill orr once before and failed. Orr was a desperate man when he learned that Baker had come for him a second time, and he acted out of character to save his own life. See Orr's account, ibid., 130-32. 
bandits were captured near Pilot Grove, and the gang scattered.

Bickerstaff managed to elude capture until April 1869 when he and two accomplices were killed near Alvarado. ${ }^{22}$ About the same time, Bob Lee was shot "while resisting arrest" outside Sherman. It had been a difficult victory for the Army; one of the companies that helped bring the outlaws to bay had marched over a thousand miles in three months. ${ }^{23}$ Other smaller gangs of outlaws plagued Texas, but few reached the potential of the Baker, Bickerstaff, or Lee bands. One group of bandits plagued Texana during the summer of 1865, while another roamed Trinity County. In a rare case of frankness, S. L. Johnson, who reported the Trinity problem to the Army, was even willing to list the names of the outlaws. Another raider, Elisha Guest, intimidated the Clarksville region. When a patrol of soldiers looking for Guest rode into Mount pleasant, the lieutenant in charge found the place "in a state of rebellion" and he had to arrest three townsmen. The officer also reported that the whole area was in sympathy with Guest. Captain

\section{${ }^{22}$ The activities of the Bickerstaff gang are described in The} Standard (Clarksville), August 15, 1868; Houston Weekly Times, September 11, 1868; Austin Republican, September 22, 1868; Capt. T. W. Tolman to AAG, August 31, 1868, Capt. A. R. Chaffee to AAG, september 21, 27, October 5, 30, 1868, Letters Received, Fifth Military District records; Reynolds to AGO, USA, April 30, 1869, AAAG to Lt. Col. W. B. Pease, April 17, 1869, Letters Sent, ibid. Both Tolman and Chaffee had trouble with civilians in the Sulphur Springs-Pilot Grove area who refused to be disarmed and had to be shot. The Army was accused of several atrocities in this area. See McConnell, Five Years A Cavalryman, 192 .

$23_{\text {For }}$ the Bob Lee gang, see W. H. Carter, "The Sixth Regiment of Cavalry," in Rodenbough and Haskin (eds.), The Army of the United States, 242; Texas News (Bonham), May 28, 1869; Lt. M. P. Eakin to AAG, February 8, 1869, Bvt. Lt. Col. R. M. Morris to AAG, June 8, 1869, Letters Received, Fifth Military District records; Secretary of Civil Affairs to W. C. Philips, July 14, 1869, Letters Sent, Civil Affairs, ibid. There had been a reward of $\$ 1,000$ each for Baker, Bickerstaff and Lee. See The Standard (Clarksville), September 19, 1868. 
A. R. Chaffee, who participated in the destruction of the Bickerstaff gang, recommended that Guest's head be priced at the standard $\$ 1,000$ rate, dead or alive. Warnings by local citizens enabled a Bell County gang to escape the patrol sent to capture them, and an audacious group of brigands dressed in Yankee army uniforms terrorized the citizens of Montgomery. 24

Law enforcement was severely compromised by the frequent failure of local sheriffs to do their duty. The sheriff was very important to the Army. When soldiers arrived in a community, the first person contacted by the officer in charge was the sheriff. Troop commanders usually had orders to assist these men directly, obtain their side of any disturbance first, and follow their orders in quelling disturbances in the area. ${ }^{25}$ Although both Sheridan and

24 Brig. Gen. Joseph Conrad to AAG, August 19, 1865, ㅇ..…, XLVIII, Pt. 2, 1194; Chaffee to AAG, November 20, 1868, Bvt. Brig. Gen. George P. Buel to $A A G$, May 22, 1869, Lettexs Received, Fifth Military District records; S. L. Johnson to AAG, January --, 1868, CO, Post of Waco to AAG, August 2, 1869, P. N. Yell to AAG, August 23, 1869, ibid., Civil Affairs. The Army suspected Texans feared reprisals unless they supported the gangs, Bvt. Brig. Gen. James Shaw, Jr. to AAG, April 3, 1866, House Executive Documents, 40th Cong., 2nd Sess., No. 57, 95-96. Citizens who supported the outlaws for any reason were liable to military trial. Neighborhoods infested with guerrillas were also responsible for their acts. See Secretary of Civil Affairs to CO, Post of Austin, June 5, 1869, Letters Sent, Civil Affairs, Fifth Military District records, and GO 5, June 30, 1865, Printed Orders, Military Division of the Southwest.

25 Assuming that Democratic officials tended to ignore criminal activity against Negroes and Loyalists, and that Republican officials were especially diligent in arresting former Confederates, it was feasible for a troop contingent to report to a Democratic sheriff and act to frustrate Repubilican objectives in an area. Reynolds never did remove all the Democratic officeholders on the local level, Journal of the Reconstruction Convention . . 1868, I, 200-201. In January 1869, Reynolds warned local authorities against using posses composed of men from one political party. Justice was to be impartial, said the general, and all able-bodied volunteers were to be accepted regardless of political sympathy. See GO 7, January 21, 1869, Printed 
Griffin found it beneath their dignity to trust an ex-Rebel like Throckmorton, the governor did his best to work with the military in the matter of law enforcement. ${ }^{26}$ The governor regularly offered rewards for the capture of dangerous criminals and he sent special agents to make difficult arrests. He wrote repeatedly to local officials that "the laws ought to be rigidly enforced. It can only be done by the [civil] officers energetically discharging their duty." The governor ordered local officials to act vigorously when race was involved. This prompted Griffin to write Throckmorton a letter in which he sarcastically stated that he was happy to hear of the governor's desire to cooperate with the military in enforcing the state's criminal laws. Griffin magnanimously concluded that there would be no "embarrassment or difficulty" in Texas Reconstruction although his unenthusiastic tone of voice belied his true feelings. 27 Griffin's suspicions were brought about by the fact that Throckmorton never really managed to get the local elected officials,

Orders, Fifth Military District; AAAG to CO, Post of Galveston, June 16, 1868, AAG to CO, Post of Austin, January 20, 1869, Letters sent, Fifth Military District records; Secretary of Civil Affairs to John B. Johnson, May 19, 1869, ibid., Civil Affairs; CO, Post of Austin to AAG, June 15, 1869, Letters Received, ibid.

${ }^{26}$ Sheridan's assertion that everything was going along peacefully until Throckmorton assumed office is erroneous. Hamilton had the same problems with lawbreakers because sheriffs refused to act. See Sheridan, Personal Memoirs, II, 232; Sheridan to Grant, October 6, 1866, House Executive Documents, 40th Cong., 2nd Sess., No. 57, 18. Elizabeth Custer, Tenting on the plains, 262, mentions Hamilton's use of the military to preserve order.

27 Throckmorton to Griffin, March 7, 27, 1867, Throckmorton to Brig. Gen. Oakes, April 29, 1867, Throckmorton papers; Brownsville Daily Ranchero, May 26, 1867; Throckmorton to Panola County Attorney, April 2, 1867, Throckmorton to Griffin, March 7, 1867, Executive Correspondence; Griffin to Throckmorton, April 11, 1867, Governor's papers (Throckmorton). 
generally Democrats, to go along with his policy of cooperation with the Army. The town constable and the deputy sheriff of Jefferson typified the problem. Hugh Freeman, a local tough with a reputation for killing Negroes and soldiers, murdered a freedman named "Rough Alexander." The justice of the peace ordered Freeman's arrest but both the deputy sheriff and the constable refused to serve the warrant even after the Army offered to assist them with a squad of soldiers. When the lieutenant in charge of the patrol tried to make the arrest, several townspeople held him at bay with loaded revolvers while Freeman escaped. For their act of defiance the deputy and the constable were removed from office. 28

On the other hand, conscientious Republican judges found it necessary to have soldiers guard their courtrooms. Judge Moses B. Walker of the Fourth Judicial District, traveled his circuit with an escort of soldiers. Judge B. F. Barkley of Fort worth took the same precaution. The fear of assassination, however, drove many a lesser man from office. Others became more selective about whom they arrested and tried for crimes. Officials who were lax in prosecuting criminals were frequently warned by the Army "to use increased diligence" and were removed from office if they did not. Although it was a poor option, removal from office was the only effective threat the governor and the Army had. Throckmorton, however, was too opposed to military interference in state government to wholeheartedly follow this alter-

28 First Lt. Stanton Weaver to AAG, May 24, 1867, House Execu-

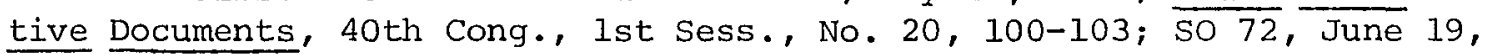
1867, Printed Orders, Fifth Military District. Some military officers were also negligent in arresting lawbreakers. See Moore, "Anderson County During Reconstruction," 9; AAAG to CO, Post of Wharton, January 25, 1869, Letters Sent, Fifth Military District records. 
native. Besides, the net effect of the removals was to eliminate the few men who would serve as sheriff or county judge. An 1869 Army investigation into disturbances near Boston, Texas, revealed there had been no town government for years, even the town charter had been misplaced in the resulting chaos. 29

By 1868 the situation had deteriorated to such an extent that the state convention appointed a special committee on lawlessness and violence. This committee found that between June 1865 and June 1868 a total of 939 muxders had been recorded in Texas. The committee had not attempted to catalog assaults with intent to kill, rapes, robberies, whippings of freedmen, and other outrages because "such a summation would impose an endless task." The investigators believed that many "of these homicides have doubtless been committed for the purpose of plunder and robbery"; they found the highways crowded with thieves, most of whom were ex-Confederate soldiers. 30

The convention's committee was also appalled at the large number of freedmen killed by whites. Deaths of blacks composed 429 of the total homicides. Of those, 379 had been committed by whites; but, said the committee, freedmen were responsible for killing only ten

${ }^{29} \mathrm{CO}$, Post of Austin to AAG, July 5, 1869, Judge B. F. Barkley to AAG, September 5, 1869, April 27, 1870, Letters Received, Civil Affairs, Fifth Military District records; so 42, February 20, 1869, so 256, November 1, 1869, Printed Orders, Fifth Military District; Speer, History of Blanco County, 46; Sergeant, "Early History of Tarrant County," 180; Capt. N. H. Randlett to AAG, July 2, 1867, Governor's papers (Throckmorton); CO, Post of Austin to AAG, January 15, 1869, Second Lt. James Davidson to AAG, June 21, 1869, Letters Received, Civil Affairs, Fifth Military District records. See also, Assistant Secretary of Civil Affairs to Judge W. R. Fayle, August 31, 1869, Letters Sent, ibid. $193-94$.

$$
{ }^{30} \text { Journal of the Reconstruction Convention. . 1868, I, }
$$


whites. "This great disparity between the numbers of the two races killed, the one by the other," concluded the investigators, "shows conclusively that 'the war of the races' is all on the part of the whites against the blacks." Further, the committee insisted that most of the 470 whites who had met a violent death were Unionists, while their attackers, with few exceptions, were former Rebels. "The obligations of the government and of the citizens are mutual and correlative," said the committee. "If the true allegiance is rendered by the latter, ample protection is due from the former." The report closed with a plea "that Congress may afford such relief as, in their wisdom, we may be entitled to." 31

In August 1868 pressure caused by the convention report and increased disorder in northeastern Texas forced General Reynolds to send Lieutenant Charles A. Vernon to investigate the disturbances. Vernon visited as many towns as possible and assured the local authorities that the Army would uphold the law without regard to political party. The lieutenant also insisted that the civil processes be used in all disputes. The local law officers were warned that they were expected to fulfill the demands of their positions and told that they would receive all the military aid they needed to keep the peace. At the same time Reynolds obtained the Fifteenth Infantry and sent the regiment to Marshall and Jefferson to bolster the defense of that area. $^{32}$

$$
{ }^{31} \text { Ibid. , 194-96, } 203 .
$$

32 AAAG to Lt. Charles A. Vernon, August 11, 1868, AAG to Brig. Gen. O. L. Shepard, August 18, 1868, Letters Sent, Fifth Military District records; Reynolds to AAG, June 11, 1868, Letters Received, ibid. 
In January 1869 General Canby, the new commander of the Fifth Military District, issued General Orders No. 4 in response to new depredations. This command was designed to secure prompt and exact execution of the laws, protect ali persons in their rights and property, and suppress insurrection. Canby told all post commanders to assume the powers of county officials and judges and to use the civil courts and Texas law to suppress the rampant lawlessness in the state. Canby hoped for the "moral support" of all "good citizens" to "avoid the necessity of military interference," but he authorized the use of military courts in criminal cases if civil officials refused to cooperate. He then divided Texas into twenty-nine patrol areas and detailed soldiers to each zone. Troop commanders were to dispose of their units as they saw fit, but a central reserve force was to be kept at each district headquarters. Canby hoped the assignments would allow the Army to obtain more complete control by setting up a distinct chain of command and responsibilities. ${ }^{33}$ when a fugitive fled from one zone to the next, district commanders were authorized to continue pursuit provided that they notified the officer in charge of

${ }^{33}$ GO 4, January 16, 1869, Printed Orders, Fifth Military District. Canby also was trying to alleviate complaints received from his post commanders about a lack of sufficient numbers of officers. See, e.g., Second Lt. C. G. Gordon to AAG, March 9, 1868, Letters Received, District of Texas records; AAAG to Capt. F. W. Bailey, September 28, 1868, Letters Sent, Fifth Military District records; Bvt. Lt. Col. E. B. Beaumont to AAG, June 29, 1869, Letters Received, ibid. Another problem was inadequate horseflesh. See Bvt. Lt. Col. A. W. Evans to AAG, April 2, 1867, "Transcript of Records, 1838-1869"; Second Lt. J. H. Sands to AAAG, October 3, 1868, Letters Received, Fifth Military District records; AAAG to CO, Post of Columbus, May 31 , 1869, Letters Sent, ibid.; Lt. Col. James H. Carleton to AAG, March 24, 1870, Letters Received, ibid. Both problems continued to plague the Texas command throughout Reconstruction. 
the next area. Unless the pursuit was immediate, however, Canby preferred officers to signal the next zone officer to continue the chase. 34

A few days later, Canby set forth additional orders which included pertinent sections of the state Code of Criminal Procedure. This described the duties of civil magistrates and peace officers in preventing and punishing crime and detailed the procedures for arresting fugitives and suppressing riots. Sheriffs and judges were ordered to report anyone who threatened or obstructed them. All "combinations or conspiracies" were to be tried by military courts and punished according to Federal law. Each month sheriffs and marshals were to make consolidated reports of all crimes that occurred within their jurisdiction and send them to the nearest post commander. Clerks of court were to report immediately all persons charged with serious crimes who had forfeited their bail by not appearing in court. Garrison officers were expected to have a list of all the civil officers in their area and to recommend names to fill all vacancies. The civil officers were warned to enforce the laws while Army officers were instructed to render aid and strictly discipline their men. 35

Canby also called attention to the poor security of Texas jails. Once the Army turned a prisoner over to trustworthy civil authorities he was very likely to escape. The jailhouses were in very poor con-

34 AAAG to Capt. James Thompson, February 24, 1869, AAAG to Buel, February 26, 1869, AAAG to CO, Camp Concordia, April 1, 1869, Letters Sent, Fifth Military District records. See also, secretary of Civil Affairs to CO, Post of Austin, June 2, 1869, id. to CO, Post of san Antonio, June 8, 1869, id. to CO, Post of Waco, June 17, 1869, Letters Sent, Civil Affairs, ib id.

${ }^{35} \mathrm{GO} 5$, January 20, 1869, Printed Orders, Fifth Military District. 
dition and were inadequately guarded. Not only could the locks be picked easily, but in Georgetown duplicate keys for jail locks were available at any hardware store. ${ }^{36}$ To solve the problem, the Army constructed its own jails. The stockades, known as "bull pens," were generally small log forts with walls ten feet high and a guard walk near the top. There was rarely any permanent shelter so the prisoners took refuge from the weather in small A-tents. If the troopers were in an extremely hostile town, they spent the nights within the walls of the stockade for protection. Town jails were also "up-graded" by the Army and made more secure. At Bryan, which had no jail, the military supervised the construction of a structure fifteen feet off the ground on four uprights. Called the "Bryan sky parlor," this imposing jailhouse could be reached only by means of a removable ladder. ${ }^{37}$ Life in the stockade was harsh. At Corpus Christi one prisoner complained of having been held in solitary confinement in an iron cage exposed to the elements. The prisoners at Brownsville claimed to be overworked, underfed, and unsuitably housed. 38

${ }^{36}$ AAAG to Judge G. T. Harris, May 26, 1869, Letters Sent, Fifth Military District records; Carleton to AAG, May 6, 1869, Anonymous to AAG, May 3, 1869, Letters Received, ibid.

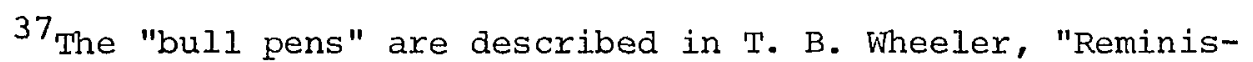
cences of Reconstruction in Texas," The guartexly of the Texas State Historical Association, XI (1907-1908), 62-64; Alexander White Neville, A History of Lamar County, Texas (Paris, Texas, 1937), 137; St. Clair, "History of Hopkins County, "65-66; Barkley, History of Travis County and Austin, 97. The Bryan jail is mentioned in Joseph M. Nance, Early History of Bryan and the Surrounding Area (College Station, Texas, 1962), [47]; and Elmer Grady Marshall, "The History of Brazos County, Texas" (Unpublished M.A. thesis, University of Texas, Austin, 1937), $85 c$.

${ }^{38}$ Secretary of Civil Affairs to Reynolds, May 12, 1868, Letters Sent, Civil Affairs, Fifth Military District records; Prisoners of Brownsville to AAG, December 15, 1867, Letters Received, ibid. 
At times, however, military jails were not much more secure than their civilian counterparts. Sentries were bribed by prisoners to desert and help them escape. The stockade at Jefferson was a town joke. It was broken into by a mob which murdered four prisoners. Other inmates regularly escaped from sentinels, which prompted Brigadier General George P. Buel, commander of the Fifteenth Infantry, to threaten to bring charges of negligence and disobedience against any Officer of the Day who had an escape on his watch. Buel had to assign sole control of the jail to his executive officer, restrict keys to the sergeant of the guard, and curtail visiting privileges to stop the rash of escapes. 39

As Canby correctly observed, the "moral support of all good citizens," and "the timely exercise of the powers" with which the peace officers were invested would "generally preserve the peace and prevent the commission of crime."40 At the same time, he warned military officers against "harshly or oppressively" executing the Reconstruction Acts. They were to see "that arrests are not made without sufficient cause; that the manner of arrest shall, as far as practicable, be the same as is prescribed by the laws of the state . . . "41 Many months passed before a correspondent was able to inform the Army

39 Reynolds to AAG, May 12, 1868, Letters Sent, District of Texas records; Bvt. Lt. Col. James Biddle to AAG, June 28, 1869, Letters Received, Fifth Military District records; GO 15, October 12, 1868, Printed Orders, Fifth Military District; Buel to AAG, May 16, 22, 23, 1869, Letters Received, Fifth Military District records. District.

${ }^{40}$ GO 4, January 16, 1869, Printed Orders, Fifth Military

${ }^{41_{\text {GO }}} 5$, January 20,1869 , ibid. 
and Navy Journal that there were two sides forming in Texas; the Army and the people against the desperadoes. ${ }^{42}$ The judicious action of General Canby in January 1869 was responsible, to a large extent, for this change in attitude which helped bring Texas much of the way from hell toward good society.

42 Army and Navy Journal, VII (September 25, 1869), 78. 
XI. EQUAL JUSTICE FOR ALL

An integral part of the problem of maintaining law and order in Texas was the operation of the state courts. There were three court systems in Texas during Reconstruction, all of which competed with each other for criminal jurisdiction. The Freedmen's Bureau courts had first claim on all cases dealing with Negroes. The state courts claimed jurisdiction in all criminal cases, and the Army had its own military tribunals that tried cases involving Federal personnel. The Army could also interfere in state trials in which a defendant received an unfair hearing because of his race or politics. ${ }^{1}$

Unfair trials were a common occurrence in Texas according to both Loyalists and former Secessionists. The Unionist position was well stated in the 1868-1869 convention proceedings. Loyalists "feel that the courts are only employed as an engine for their oppression -. ." It was the convention's solemn conviction that the courts, especially the juries, as a rule would not convict ex-Rebels for offenses committed against Union men or freedmen. Of the 249 indictments for murder in the state in the first three years following the surrender, only five men had been convicted in state courts, the statement concluded. A single legal execution took place and the victim was a freedman. Similar reports filtered into military headquar-

${ }^{1}$ Ramsdell, Reconstruction in Texas, 77-78. The Bureau courts are handled in chapter IX above. 
ters: a man in McLennan County claimed he could not obtain justice in Waco courts; excessive fines and "incompetent" juries were common in Navasota; several counties requested new judges; and in Anderson a citizen reported the grand jury failed to indict a man for assault and battery. ${ }^{2}$

Identical protests came from former Confederates who asserted that they also had been denied justice. The Tarrant county court was headed by A. B. Norton and Hardin Hart; the former was a carpetbagger while the latter was a scalawag, and both were distrusted and hated by local whites. In Refugio County the police courts reportedly dealt "summarily" with violators and gave "such orders as pleased it and arrested and tried those whom it saw fit." One source stated that any ex-Confederate would lose his case in San Antonio's courts. ${ }^{3}$

Undoubtedly both sides told the truth. Courts were biased according to the political affiliation of the judge and jury. But in the story of Reconstruction the salient point is that those courts that refused to fairly consider cases involving Unionists and freedmen were openly mocking the results of the war. They were denying the victor the symbolic proofs of his triumph. 4

J. R. Burns, a citizen of La Grange, warned his fellow Texans

\footnotetext{
${ }^{2}$ Journal of the Reconstruction Convention . . . 1868, I, 198200; N. Patten to AAG, Apri1 13, 1867, Thomas J. Jennings to AAG, December 21, 1867, W. H. King to $A A G$, n.d., Letters Received, Civil Affairs, Fifth Military District records; A. M. Boatright to AAG, Apxil 15, 1867, Letters Received, Civil Affairs, District of Texas records; H. S. Thomas to AAG, June 24, 1867, Letters Received, ibid.

${ }^{3}$ Sergeant, "Early History of Tarrant County," 175-76; Huson, Refugio, II, 126; Taylor Thompson, "Reconstruction Days in San Antonio," Frontier Times (November 1923), 29.

${ }^{4}$ The necessity for the ritual of acting out one's defeat is described in Mckitrick, Andrew Joinson and Reconstruction, 15-41.
} 
against such folly. Unless the state courts upheld equal justice for all, said Burns, "military men who for the most part know but little of civil justice and law and not much more about its administration" will take them over. "Would it not be better for the people to have their controversies and difficulties settled by their own fellow citizens than by military strangers?" asked Burns. He preferred "to have the judgment of the courts executed by process in the hands of their fellow citizen sheriffs than by the bayonet in the hands of some military Tom, Dick, or Harry--by perhaps a white soldier--perhaps a black one!"5 Unfortunately Burns' warning went unheeded.

The ultimate in Rebel defiance occurred when the Eleventh Legislature gerrymandered Judges Thomas A. Stribling and W. P. Bacon off the bench. Stribling and Bacon and six other Unionists had been elected to office on June 25, 1866. Eight of twenty district judgeships had been won by Loyalists in that election, an extremely good showing in "Rebel" Texas. The Democratic legislature decided to "purify" the district courts and that fall it abolished five court districts. The legislature also wanted to eliminate the district of Judge G. H. Noonan of Uvalde, but geographical considerations forced them to reconsider. 6

Immediate protests flooded headquarters. 7 In response, Sheri(Hamilton).

${ }^{5}$ J. R. Burns to Hamilton, November 15, 1865, Governor's papers

$6^{\mathrm{J}}$. L. Haynes to Griffin, April 30, 1867, House Executive Documents, 40th Cong., 1st Sess., No. 20, 90-94; Griffin to AAG, June 7, 1867, Telegrams Received, Fifth Military District records.

${ }^{7}$ See e.g., Citizens of San Antonio to AAG, March 28, 1867, R. Walfing and others to AAG, March 28, 1867, Letters Received, Civil Affairs, Fifth Military District records; Citizens of San Antonio to AAG, March 28, 1867, ibid., District of Texas records. 
dan decreed that the districts of Stribling and Bacon be re-established as they originally were. He remarked that the only reason the districts had been abolished was the Unionist opinion of the jurists, and that the new districts were "of such extent as to make it impossible to administer justice within them through the courts." Sheridan informed Grant that reports of Bacon's unfitness were "humbug" and that his El Paso court was necessary to prevent citizens from having to use courts in New Mexico Territory. Griffin later tried to have all of the districts set back as they were in June 1866, but he apparently did not succeed. 8

The military commanders did not like to interfere with the civil courts' jurisdiction. ${ }^{9}$ Sheridan warned his officers to give way to the civil authorities whenever possible, "for it is hard to enforce martial law after war has ceased and a form of civil government is in existence." General Wright wrote to Hamilton that all matters concerning whites were to be handled by the civil government while those affecting blacks would be dealt with by the Freedmen's Bureau. The Army would render assistance to either of these bodies only if it were necessary. But if the civil courts failed to act justly, the

${ }^{8}$ SO 65, June 10, 1867, SO 208, November 20, 1867, Printed Orders, Fifth Military District; Sheridan to Griffin, June 10, 1867, Letters Sent, Fifth Military District records; Sheridan to Grant, June 20, 1867 (letter and telegram), Grant papers; Griffin to Sheridan, August 13, 1867, Letters Sent, District of Texas records. No answer or order in response to Griffin's letter was found.

${ }^{9}$ Cases involving private property were never tried by military courts. See AAAG to W. H. Griffin, May 7, 1869, Letters Sent, Fifth Military District records; Assistant Secretary of Civil Affairs to CO, Post of Jefferson, August 9, 1869, ibid., Civil Affairs. 
Army would step in and transfer the case to the Bureau courts or use its own military tribunals. ${ }^{10}$

Although General Wright's position was fairly moderate, individual officers went far beyond his original intent when they confiscated county court records. The Calhoun County archives and court records were removed to Indianola by a provost marshal who refused to give the county clerk a receipt for the papers. In seguin the local post commander forcibly seized and destroyed certain court records and refused to allow a fellow officer to stand trial on gambling charges. Shortly thereafter, a Sixth Cavalry patrol mutilated the records of the Lockhart courthouse, while in Grayson County, elements of the same regiment removed a prisoner from the county jail. In Hopkins County, the soldiers changed the location of the court records and archives from Tarrant to Sulphur springs where they were stationed. This angered the citizens of Tarrant. When a new post commandex was assigned, the Tarrant men took advantage of his tolerant nature and moved the records back to the old courthouse. ${ }^{11}$

President Johnson, however, wanted no interference with civil government and he ordered the practice stopped completely. Then in the spring of 1866, he issued his proclamation declaring that the "insurrection is at an end and that peace, order, tranquillity, and

${ }^{10}$ Sheridan, Personal Memoirs. II, 260-61; Sheridan to Rawlins, October 7, 1865, Grant papers; Wright to Hamilton, October 10, 1865, Governor's papers (Hamilton).

${ }^{11}$ John R. Burke to Hamilton, August 4, 1865, Governor's papers (Hamilton); Throckmorton to Kiddoo, October 13, 1866, Throckmorton to Getty, October 13, 1866, Throckmorton to Sheridan, October 30, 1866, Throckmorton to Heintzelman, October 30, 1866, in Throckmorton papers; st. Clair, "History of Hopkins County," 64-65. 
civil authority now exist. . . ." This statement created some confusion in Texas. Governor Throckmorton felt the proclamation restored all judicial authority to the state courts. The attorney general, Henry stambery, wrote the governor that orders had been sent to the military "as will prevent the collision between military and civil jurisdiction in the state of Texas." Sheridan thought the President's proclamation did not interfere with martial law or the Freedmen's Bureau courts, but Grant informed him differently. 12

The state judges had been confused all along. The chief justice of Bell County inquired as to what he was to do with black vagrants, orphans, and invalids? Could freedmen sue whites, give valid testimony against whites, claim property from their former masters? Another judge wanted to know if he was required to drop charges against some treasury agents; he hated to see state sovereignty so maligned. These and other questions continued to plague the justices as 1ate as 1867, as witness the letter from the Army to Judge William H. Burckhart advising him that he could not discriminate between black and white testimony. Another jurist wished to know if he could hold court in cases where no jury was necessary; he had been a Unionist but he went with the state in 1861. He claimed that most of his cases involved

\footnotetext{
12 Edwin M. Stanton to Sheridan, October 10, 1865, Governor's papers (Hamilton); Richardson (comp.), A Compilation of the Messages and Papers of the Presidents, VI, 429-32, 437-38. See also, Throckmorton to Heintzelman, September 8, 1866, Throckmorton papers; H. Stanbery to Throckmorton, November 6, 1866, Governor's papers (Throckmorton). The following orders were negated: GO 5, January 27, 1866, GO 21, April 23, 1866, and Circ. 3, April 17, 1866, Printed Orders, District of Texas. See also, George K. Leet to Sheridan, November 1 , 1866, House Executive Documents, 40th Cong., 2nd Sess., No. 57, 18-19. Sefton, The United States Army and Reconstruction, 74-82, discusses the confusion among the Army commanders.
} 
freedmen who were quick to take each other to court for picayune matters. 13

The Reconstruction Acts ended much of the confusion and gave the Army a new sanction to supervise the state courts. Post commanders received orders to take charge in all cases of suspected injustice and forward all particulars to higher headquarters. ${ }^{14}$ Under this circular, Army officers ordered stays in prosecution, ${ }^{15}$ dismissal of cases, 16 changes of venue, ${ }^{17}$ reduced sentences, ${ }^{18}$ and transferral of cases to military courts. ${ }^{19}$ The Army also sent reporters to important trials or asked for full transcripts from the clerks of court. ${ }^{20}$ The military gave permission for lawyers to defend clients ${ }^{21}$ and released prisoners

13 Hiram Christian to Hamilton, October 21, 1865, B. W. Gray to Hamilton, November 30, 1865, Governor's papers (Hamilton); Secretary of Civil Affairs to W. H. Burckhart, April 29, 1867, Letters Sent, Civil Affairs, District of Texas records; John E. George to AAG, March 30, 1867, Letters Received, ibid. See also, Throckmorton to Griffin, May 14, 1866, Throckmorton papers.

${ }^{14}$ Circ. 10, April 5, 1867, Printed Orders, District of Texas.

${ }^{15}$ First Lt. S. C. Plummer to Judge Ireland, May 14, 1867, Governor's papers (Throckmorton).

${ }^{16}$ Bvt. Brig. Gen. James Oakes to Judge, Second Judicial District, May 25, 1867, ibid.; So 193, October 30, 1867, Printed Orders, District of Texas.

${ }^{17}$ So 187, October 18, 1867, Printed Orders, District of Texas.

${ }^{18}$ SO 192, November 21, 1867, Printed Orders, Fifth Military District.

19 AAAG to CO, Ft. MCKavett, March 15, 1869, Letters Sent, Fifth Military District records.

20 John W. Harris to AAG, March 23, 1868, ibid.; Secretary of Civil Affairs to B. B. Hart, June 1, 1869, Letters Sent, Civil Affairs, ibid.

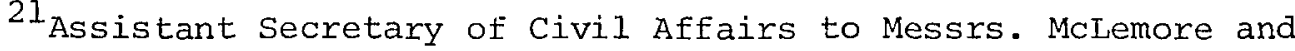
Hume, August 19, 1869, Letters Sent, Civil Affairs, ibid.
} 
on bond. ${ }^{22}$ Headquarters helped organize United States district courts, and extended the justice of the peace courts within the state. $^{23}$ Most importantly, the Army ordered courts to meet in several counties that had had no legal proceedings for as long as two years. The military approved lengthened sessions to help them clear their crowded dockets. ${ }^{24}$ whenever possible, officers were instructed to allow the civil authorities to make the first move. If they refused, then the Army could prod them along. The Army tried to keep local petit juries, grand juries, and judges from abdicating theix responsibility of treating all defendants equally. 25

The most controversial military interfexence with the civil courts occurred on April 27, 1867, when Griffin issued Circular No. 13 . Griffin was concerned over the discriminatory treatment Negroes had been receiving in Texas courts, and he was determined to act. He first supported the Freedmen's Bureau's attempt to free all of the black prisoners incarcerated at the Huntsville penitentiary. For his trouble, he received a refusal and an eight-page morality lecture from

${ }^{22}$ Canby to CO, Post of Jefferson, January 8, 1869, ibid.; Assistant Secretary of Civil Affairs to CO, Post of Helena, September 11, 1869, Letters Sent, Fifth Military District records.

23 Wright to AAG, November 20, 1865, House Reports, 39th Cong., 2nd Sess., No. 61, I; GO 27, March 17, 1869, Printed Orders, Fifth Military District.

${ }^{24}$ SO 142, September 18, 1867, so 1, January 2, 1868, so 107, December 24, 1868, SO 109, December 28, 1868, Printed Orders, District of Texas. See also, Wesley Ogden to Pease, August 5, 1868, Governor's papers (Pease); Cassles, "History of Hunt County," 56.

25 AAG to CO, Ft. Duncan, March 24, 1869, AAG to Gen. J. Hayden, December 3, 1868, Letters Sent, Fifth Military District records; Assistant Secretary of Civil Affairs to CO, Post of Bryan, September 1, 1869, ibid., Civil Affairs. 
Governor Throckmorton. ${ }^{26}$ The rebuffed general then issued his circular to prevent "persons disqualified by law" from serving as jurors. The circular required that all potential jurymen take the "ironclad oath" that they had not voluntarily given "aid, countenance, counsel or encouragement" to the Confederacy. In the same order, he printed section 2 of the Civil Rights Act of 1867 which provided that anyone who "under color of any law, statute, ordinance, regulation or custom" deprived any citizen of his civil rights was guilty of a misdemeanor, and subject to a fine of $\$ 1,000$ or one year in jail or both. 27

The effect of the "jury order" was to exclude the Secessionists from courtroom juries, producing a howl of rage from whites throughout the state. A Houston man wrote to President Johnson pleading with him to alleviate "the helpless, wretched condition of a people denied the protection of courts of law . . ." A lawyer from Rusk wrote the President that there were not twelve whites in the entire county who could take the "ironclad oath," and he protested using uneducated Negroes as jurors. He also stated that he had recently represented a freedman who sued a white man and had received justice from a white court. Fifteen attorneys Erom Jefferson sent a petition to the White House in which they expressed fears that the oath was too strict and Negroes were too ignorant to be jurors. Another lawyer told Governor Throckmorton that the inability of whites to serve on juries would prevent trying all the cases in his area unless the defendants would

26 Throckmorton to Oakes, March 18, 1867, Governor's papers (Throckmorton). Haynes, "Some Features of Negro Participation in Texas History Through 1879," 72, alludes to this incident but her facts are somewhat confused.

${ }^{27}$ Circ. 13, April 27, 1867, Printed Orders, District of Texas. 
waive their right to a jury trial. The Brownsville Daily Ranchero printed a plea for white jurors to come forward and noted that there was a great aversion to taking the oath. 28

Other whites simply boycotted the courts. Alexander W. Terrell, a prominent Houston attorney, argued a case before a Negro jury, the members of which had been conscripted from a construction site across the street from the Harris County courthouse. The clerk of court had to write out the verdict and note each juror's name after his " $\mathrm{X}$ " mark. Terrell was too outraged at the whole idea to mention whether the decision was a reasonable one. He disgustedly abandoned his profession and took up managing a Brazos plantation. As Terrell phrased it, "I found it more congenial with my nature to direct negroes in the field than to bow before them and call them 'gentlemen of the jury. ' " 29

Governor Throckmorton placed the plight of his constituents before the President, but at the same time he advised all judges to follow the circular until further notice. Throckmorton felt it was unfair that Federal juries in the state did not have to take the "ironclad oath" while those in state courts did. When Griffin heard of this charge, he made inquiries and found the oath was taken at the discration of the judge in Federal courts. Throckmorton sent Griffin

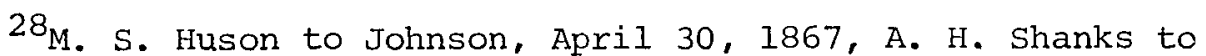
Johnson, May 8, 1867, G. B. Lipscomb and others to Johnson, May 9, 1867, Johnson papers; M. D. Ector to Throckmorton, May 10, 1867, Governor's papers (Thrnckmorton); Brownsville Daily Ranchero, May 11, 1867. Even some Unionists felt the circular was excessive, see [torn] to Hamilton, May 29, 1867, Hamilton papers.

29 Mary Ellen Wallis, "The Life of Alexander Watkins Terrell, 1827-1912" (Unpublished M.A. thesis, University of Texas, Austin, 1937), 70-71. 
a copy of his letter to Johnson because he felt that the circular had been misrepresented to the general. Privately, however, Throckmorton suspected that the general had issued the jury circular in order to force him to oppose it, thus giving Griffin cause to remove him from office. 30

The massive attack on Circular No. 13 put Griffin on the defensive. He justified his order to Grant by stating that its purpose was not to force Negro jurors on Texas, 31 but rather to ensure that loyal whites and blacks were able to serve and protect themselves from injustice. The oath was the same that Congress required of Federal officials, said Griffin. He further maintained that he had not interfered with the state requirements that a juror must be a qualified voter, a householder of the county, or a freeholder of the state. These existing regulations could exclude nearly every Negro in the state from being a juryman. He labeled as untrue the complaints that there was a lack of jurors in many counties. The problem could be solved, asserted Griffin, by going to neighboring counties for jurors. In one specific instance, Judge J. J. Holt of the Tenth Judicial District erroneously reported he had no jurors to draw on; Griffin personally knew of sixteen qualified whites, and Governor

\footnotetext{
${ }^{30}$ See printed form to all judges dated May 2, 1867, and Throckmorton to Johnson, May 2, 1867, in Throckmorton papers. See also, Griffin to Throckmorton, May 7, 1867, Griffin to Judge J. C. Watrous, May 16, 1867, Letters Sent, Civil Affairs, District of Texas records; Throckmorton to Griffin, May 20, 1867, Johnson papers; Throckmorton to B. H. Epperson, May 4, 1867, B. H. Epperson papers, Archives, University of Texas.

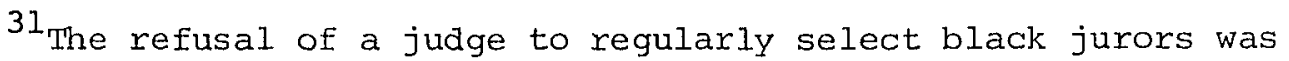
grounds for removal from office. See so 249, October 23, 1869, Printed Orders, Fifth Military District.
} 
Throckmorton had a list of thirty-eight more. ${ }^{32}$

Sheridan agreed with his subordinate. Little Phil believed it was necessary to remove "the disaffected element" from the juries because of their opposition to Reconstruction. He told Griffin that if Texas officials tried to embarrass him by including unqualified Negroes on juries, then Griffin should report them and Sheridan would remove them from office. ${ }^{33}$ one officer even recommended that Circular No. 13 be enforced throughout the Fifth Military District. This was opposed by Grant who said the rules for selecting juries should assure "equal justice for all classes." Grant insisted that if a man could be considered loyal enough to vote, he was loyal enough to serve as a juror. This policy was adopted by the end of september 1867, and the jury lists were revised accordingly. 34

The most effective method of regulating justice in Texas was the use of military commissions to try civilians. All of the commanders of the District of Texas and the Fifth Military District, except General Hancock, employed military tribunals. Hancock insisted that each case be given to a civil court before he would sanction military interference. $^{35}$ Hancock, however, seldom allowed much supervision

${ }^{32}$ Sheridan to Grant, May 22, 1867, Grant papers; Griffin to Sheridan, May 29, 1867, Griffin to Maj. George Forsyth, June 10, 1867, Sheridan papers.

${ }^{33}$ Shexidan, Personal Memoirs, II, 275; Sheridan to Griffin, May 25, 1867, House Executive Documents, 40th Cong., Ist Sess., No. 20, 72 .

${ }^{34}$ Bvt. Brig. Gen. F. T. Dent to AAG, August 8, 1867, Letters Received, Fifth Military District records; Grant to Sheridan, August 15, 1867, Sheridan to Grant, August 15, 17, 1867, Grant papers; SO 151, September 28, 1867, SO 192, October 20, 1867, Printed Orders, Fifth Military District.

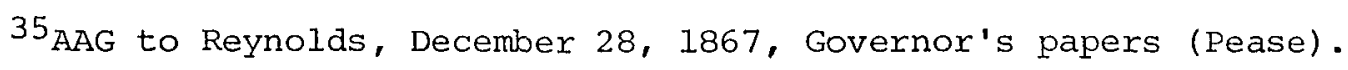


over civilian courts. Sheridan and Griffin were not as circumspect as Hancock and more ready to order military trials of civilians while General Reynolds was a devout supporter of such trials. "I am decidedly opposed to Military Commissions in the time of peace," claimed Reynolds, "except in such extreme cases as are provided for by the laws of Congress." He believed that the only way the spirit of the Reconstruction Acts could be enforced in Texas was by military tribunals. 36 But he kept strict control over military proceedings against private citizens. Officers holding civilian prisoners had to submit their names to headquarters for a ruling on the type of trial they would receive. ${ }^{37}$ No local commander could issue an order affecting civilians without the approval of Reynolds. The general also reviewed the necessity of those orders already in existence which involved citizens. 38

Besicies the obvious reason that military courts would convict those who persecuted Negroes and Unionists, the major complaint against them was that they operated on different rules of procedure than civil tribunals and could be more arbitrary. They used no juries, a twothirds vote of the bench could condemn a man to death, and officers could refuse to honor the writ of habeas corpus and hold prisoners

\footnotetext{
${ }^{36}$ Reynolds to AAG, June 8,1868 , Letters Sent, District of Texas records.
}

${ }^{37}$ GO 41, Noverber 22, 1869, Printed Orders, District of Texas; AAAG to Bvt. Maj. Gen. James H. Carleton, April 30, 1869, Letters Sent, Fifth Military District records; Assistant Secretary of Civil Affairs to $\mathrm{CO}$, Post of Jefferson, August 26, 1869, ibid., Civil Affairs.

${ }^{38}$ GO 3, August 28, 1868, Printed Orders, Fifth Military District. 
indefinitely. ${ }^{39}$ The Brownsville Daily Ranchero spoke out bitterly. against military trials of civilians in time of peace. The editor asserted that he expressed his ideas with "no unkind feeling, nor from a disposition to prejudice the case" being considered, but he held that these trials were "an unpardonable farce." Texans were helpless before them, continued the editor, and could only evoke "the coward's power--appeal to God for protection." 40

Reynolds tried to check this criticism by inviting state district attorneys to attend civilian trials held by the Army. ${ }^{41}$ There were also cases of pardon or reduction of sentences when injustice was done, and many acquittals as well as the expected convictions. ${ }^{42}$ But Texans continued to condemn the numerous trials, 43 and on occasion they took even more violent action. Lieutenant Gregory Barrett had an unpleasant experience when he found a Tyler inhabitant guilty of

${ }^{39}$ See, e..g., General Court Martial Order 51, August 11, 1866, Printed Orders, District of Texas; John E. Lockwood to AAG, January 18, 1868, Letters Received, Civil Affairs, Fifth Military District records; AAAG to Jack Helm, June 14, 1869, Letters Sent, Fifth Military District records.

40 Brownsville Daily Ranchero, August 29, September 3, 1867.

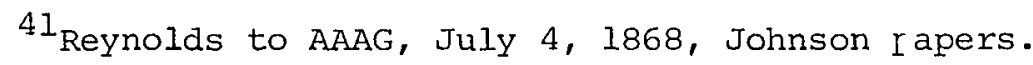

$42_{\mathrm{GO}} 37$, November 4, 1867, GO 19, October 24, 1868, GO 26, November 24, 1868, Printed Orders, Fifth Military District.

${ }^{43}$ There were thirteen commissions held in 1868, while nine were held in the first four months of 1870. Each commission tried several defendants. The one in Jefferson tried 24 persons for $\mathrm{Ku} \mathrm{Klux} \mathrm{Klan}$ activities; all but six were acquitted. See GO 202, November 12, 1869, ibid. The commission orders for 1868 are GO 12, February 1.3, GO 45, March 26, GO 67, April 1, GO 107, June 5, GO 127, July 7, GO 170, September 25, GO 175, October 2, GO 181, October 13, GO 202, November 12, GO 205, November 15, GO 211, November 20, GO 212, November 22, GO 234, December 20, 1868. For 1869, see GO 3, January 6, GO 8, January 18, GO 14, January 24, GO 26, February 10, GO 27, February 11, GO 33, February 26, GO 41, March 18, GO 53, April 6, GO 62, April 11, 1869 . 
assault. After the verdict had been read and the sentence pronounced, the defendant's friends drew concealed weapons and fired on the court from the gallery. Three soldiers were hit, and the accused escaped with his liberators. 44

Another aggravating problem was the Army's refusal to allow soldiers to be tried for crimes in state courts. The Army had good reason to believe that many of the charges were false accusations, a common form of harassment. Captain Frederick Rockwell of the Eighteenth New York Cavalry was hounded by civil authorities after his discharge. He had been arrested in Texas but freed by Sheridan's orders. He was accused of illegal actions when he was provost marshal of San Antonio. 45 Even soldiers suspected of murder received military protection or military trials, ${ }^{46}$ although occasionally a trooper would be turned over to civil authorities. 47 More often, however, when a civilian preferred charges against a soldier, he was politely ignored. A San Antonio man exemplified this plight when he wrote headquarters about the accusations he had made against Brevet Brigadier General James Oakes, the commanding officer in central Texas. He had heard nothing since filing his original complaint and he wanted an inquest

${ }^{44}$ Reynolds to AAG, July 23, 1868, Telegrams Received, Fifth Military District records.

${ }^{45}$ Sheridan to Merritt, October 21, 1865, Sheridan to Bvt. Col. E. S. Parker, November 18, 1865, Sheridan to Wright, April 9, 1866, E. D. Townsend to Sheridan, May 17, 1866, Sheridan papers.

46 Throckmorton to Heintzelman, September 8, 1866, Executive Correspondence; Throckmorton to Col. R. M. Morris, september 21, 1866, Morris to Throckmorton, September 21, 1866, Throckmorton papers.

47 Throckmorton to Griffin, January 1, 1867, Throckmorton papers. 
held in Austin where he could produce the proper witnesses. 48

The role played by the Army in arresting and punishing criminals demonstrates that the military had only the interests of the whole population in mind. The Army did its best to administer the laws fairly. In its zeal to protect the rights of the Negro and loyal whites, however, the Army frequently rode roughshod over the rights of the majority. Regardless of its noble intentions, the military's presence was thought of as nothing more or less than the negation of what Texans believed to be the democratic process of trial by a jury of one's peers.

48

C. G. Napier to AAG, February 5, 1870, Letters Received, Fifth Military District records. 
The presence of large numbers of soldiers in the South who were disliked by a majority of the whites inevitably led to clashes. In Texas, as in other southern states, wartime hatreds remained active long after the Confederate surrender. Although the blue-uniformed soldiers suffered innumerable wrongs at the hands of the local citizens, the Army itself contributed to the unrest.

Federal soldiers were frequently ostracized socially by the townspeople living near their posts. Although General Wright threatened to deal "summarily" with anyone who insulted his men, subtle means of affrontery were devised to evade punishment. The Twenty-sixth Infantry remembered Tyler, Texas, as a place of cold stares and remote citizens who spoke to soldiers only in an official capacity. The isolated feelings undermined morale, and the soldiers were more than happy when they were ordered to the Rio Grande Valley. When commanders tried to break the social barriers by inviting local belles to military dances, their efforts met with mixed success. One woman noted that her daughters received tickets and a very pressing invitation to the ball given by the Sixth Cavalry "but, of course, never thought of going." Girls who associated with Yankee soldiers were frowned upon by the rest of the population. A Houston woman wrote a confidant that she had met a mutual friend walking with a bluecoat one evening. With "a rudeness unworthy of a Southern woman, but with a spice of real spite- 
fullness," she walked up to the couple and said, "Bless my soul, if that isn't Hortense McGreel, and walking with a Yankee!"I

Although Governor Throckmorton tried to help the soldiers enter local society, his efforts were rebuffed. When an Army captain presented Throckmorton's letter of introduction to James H. Starr at Nacogdoches, Starr wrote the governor, "Accession to our social circle, forsooth! Well, my part of the 'social' matter will be quite limited. Respectful politeness . . seems proper enough . . . But my 'social Cordiality' [sic] is out of the question." starr felt that the soldiers were "instruments of oppression" and "as well might we be expected to extend social courtesies to the same persons if specifically commissioned to burn our houses, confiscate our property, and cut the throats of our children." 2

Some Texans, however, were not as unyielding about receiving the social advances of the occupation troops. In Indianola the town's initial hostility gave wal to a real friendship that resulted in the marriage of several local women to bluecoats. The Seventeenth Infantry was treated well in Hempstead, while Houston held a "complimentary ball" for elements of the regiment stationed there when they left for the frontier in 1868. Angelina County, which had voted strongly

\footnotetext{
$1_{\text {Aubrey A. Wilson, "A Soldier of the Texas Frontier: Brevet }}$ Major Robert Patterson Wilson, United States Army," West Texas Historical Association, Year Book, XXXIV (1958), 85-86. General Wright's comments are in Flake's Daily Bulletin (Galveston), January 23, 1866. See also, Amelia Barr to Jenny, March 3, [1867], Barr papers; Jeannie Chew Young to Louisa Wharton, January 16, 1866, Wharton papers.

${ }^{2}$ Quoted in John Nathan Cravens, "The Life and Activities of James Harpex Starr, 1809-1890" (Unpublished M.A. thesis, University of Texas, Austin, 1940), 302-303.
} 
against secession in 1861, received off-duty soldiers with grace. But more often the Texans' friendliness was of the type extended to the garrison commander at Centerville. "Too bad he chose to fight for the wrong side," commented a contemporary, "for he was a likeable person otherwise." Those soldiers who attended social functions did so at considerable risk. A discharged Federal soldier went to a dance in Tarrant County, his home before he joined the Army in 1865, and received several offers to fight from other young men. After escorting his lady friend home, he returned to the ball and was fired upon by unknown parties. 3

The social ostracism experienced by the Union soldiers was mild when compared to the more brutal forms of harassment they were subjected to. The blue uniform was an open invitation to murder in Texas throughout the Reconstruction period. These senseless killings began as early as September 1865 when three Yankee troopers were assaulted near Jefferson. Two of the men were killed and the third escaped by feigning death. The Eighteenth New York Cavalry had a rough time with bushwackers near Yorktown, Texas. Captain Henry J. Nolan reported that two of his men on tired horses fell behind the main column while on escort duty. When they failed to catch up, an investigating party rode back and found them murdered beside the road. In Leon County, a lone orderly was shot and dumped down a well "pollut-

3oozer, "The History of Indianola," 87; Spindler, "The History of Hempstead and the Formation of Waller County," 220; Works Progress Administration, Houston, 84; Effie Mattox Boon, "The History of Angelina County" (Unpublished M.A. thesis, University of Texas, Austin, 1937), 79; Leathers, Through the Years, 53. See also, Affidavit of F. R. Moun, January 18, 1870, Letters Received, Civil Affairs, Fifth Military District records. 
ing the water supply for some time," in the words of the area's historian. One officer swore he would burn Tyler to the ground after a mob assaulted and shot him in the county courthouse but the local judge dissuaded him from carrying out the threat. 4

Another notorious case occurred in Panola County where three homeward bound Yankees were murdered after their discharge. Governor A. J. Hamilton asked the Army to stay with the case because county officials refused to arrest and prosecute the killers. The Army, however, frequently had trouble finding the fugitives they were after. When a company of the Seventeenth Infantry arrived in Navasota to arrest two men, they were confronted by a crowd of thirty or forty townspeople who refused to let the soldiers pass. The lieutenant in charge shouted a quick command and the infantrymen surrounded the crowd and disarmed it. A search of the area failed to turn up the parties mentioned in the arrest warrant. The town newspaper editor told the lieutenant that had he made the arrests, the infantry would not have been allowed to leave town with its prisoners. In another instance, Captain Nolan of the Eighteenth New York Cavalry was seized and shot by a gang in front of a house whose owner he was about to arrest. Similar experiences awaited other officers carrying out

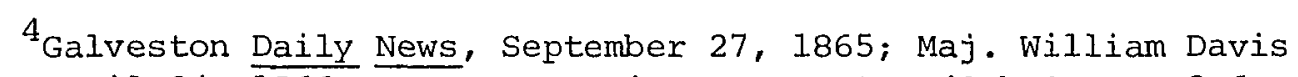
to AAG, April 24, 1866, House Executive Documents, 40th Cong., 2nd Sess., No. 57, 110; Sheridan to Mr. Barry West, June 4, 1866, Sheridan papers; AAG to Bvt. Maj. Horace Jewett, January 20, 1869, Letters Sent, Fifth Military District records; Bvt. Capt. J. Whitney to AAG, June 7, 1869, Letters Received, ibid.; CO, Post of Austin to AAG, July 5, 1869, ibid., Civil Affairs. Leathers, Through the Years, 53; Atkinson, "History of Bell County," 127-28; Moore, "Life of John Benjamin Long," 55-56. These assaults and inability or unwillingness of southern courts to convict men who attacked Federal scldiers are important reasons why Radical Reconstruction was passed in the spring of 1867. See "Murder of Union Soldiers," House Reports, 39th Cong., 2nd Sess., No. 23,5 . 
arrest orders. ${ }^{5}$

There were times when conditions deteriorated to guerrilla warfare. Brigands regularly plundered Federal supply wagons. Another tactic was to ride through towns garrisoned by the military and shoot up the streets, killing a few troopers in the process. The purpose of these hit-and-run raids was to trick the soldiers into following the raiders into ambushes. The Army quickly learned not to fall for such ruses but it was still unsafe for the bluecoats to patrol in squads of less than six. The guerrillas were so successful in their war against the soldiers that some garrisons were under a virtual state of siege. The Eighteenth New York Cavalry at Yorktown received threatening letters which stated that the post would be "attacked and wiped out." Loyal citizens were threatened with death when the soldiers left. One desperado, Cullen Baker, kept northeastern Texas in an uproar for years with his daring antics. He was reputed to have defeated, singlehandedly, a party of soldiers sent to arrest him, and he often publicly taunted the Army in the streets of Boston, Texas. 6

Local citizens supported him and other outlaws either from fear

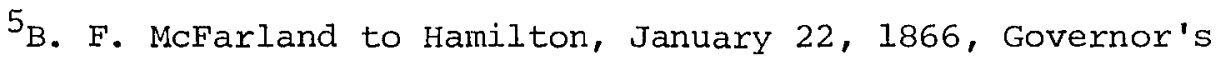
papers (Hamilton); First Lt. William A. Sutherland to AAG, March 23, 1867, "Transcript of Records, 1838-1869"; Maj. William Davis to AAG, March 29, 1866, Capt. Collin Cheesebrough to AAG, March 29, 1866, McFarland to Sheridan, March 30, 1867, House Executive Documents, 40th Cong., 2nd Sess., No. 57, 107, 126-27; Sheridan to Mr. Barry West, June 4, 1866, Sheridan papers.

6 Maj. William Davis to AAG, April 27, 1866, House Executive Documents, 40th Cong., 2nd Sess., No. 57, 108; Paul Carl Boethel, "The History of Lavaca County, 1685-1930" (Unpublished M.A. thes is, University of Texas, Austin, 1932), 99; Maurice Mattie O'Bannion, "The History of Caldwell County" (Unpublished M.A. thesis, University of Texas, Austin, 1931), 151; Marshall, "The History of Brazos County," 85b-85c; Chandler, "History of Bowie County," 49-50. 
or a misplaced feeling that they were upholding the southern way of life. Civil juries found men accused of beating soldiers "nonnegligent." The cases had few reliable witnesses, thus making it almost impossible to determine who struck the first blow. In addition, legal action was taken against commanders who were overzealous in handling Reconstruction duties. When Congress came to their aid and passed a law providing accused officers with legal help at government expense, the citizens devised other stratagems to occupy the officers. Local newspapers accused officers of illegal acts and printed slanderous materials which undermined what little public confidence the Army had gained. The only real solution was to transfer these officers to other posts or send them on detached duty. General Heintzelman was once accosted by the sheriff of Galveston who claimed he had a warrant for the general's arrest. Heintzelman demanded to see it. The sheriff decided he must have misplaced it and promised to return later to complete the task. Heintzelman ended the conversation saying that he would not be arrested by anyone. The sheriff never returned, and Heintzelman reported to his superiors that he would not have considered his life safe in the hands of civil authorities. 7

The United States Army, however, was not without guilt in many of the incidents between soldiers and civilians. One problem was the low quality of a large portion of the enlisted men in any regiment.

${ }^{7} \mathrm{CO}$, Post of Jefferson to AAG, May 21, 1869, Letters Received, Civil Affairs, Fifth Military District records; Second Lt. J. H. Jones to AAG, June 22, 1869, Letters Received, Fifth Military District records; Dallas Herald, October 13, 1866; U. S., Statutes at Large, $\mathrm{xV}, 248$; Circ. 1, January 17, 1867, Printed Orders, District of the Gulf; Maj. G. C. Cram to AAG, August 1, 1868, Letters Received, District of Texas records; Heintzelman to AAG, December 27, 1866, Heintze1man papers. 
H. H. McConnell, a Sixth Cavalry trooper, characterized the recruits he met as "bounty jumpers, blackguards, and criminals." McConnell believed they "had sought the army as an asylum from the punishments that the law would have justly meted out to them had they remained in civil life." There were exceptions, of course (McConnell immodestly considered himself a prime example), "but the vast majority of those who joined the service. . . had some urgent if not good reason for doing so." The end of the Rebellion had left only the "riff-raff of the war" among the enlisted men, and a covey of jealous, quarreling officers, angry with their recent demotions in rank. 8 The members of the Seventeenth Infantry typified the class of soldier described by McConnell. The citizens of Galveston had originally welcomed the arrival of the seventeenth because it heralded the end of the town's occupation by Negro troops. ${ }^{9}$ It soon became obvious to the most devout white supremacists that their joy was for naught. The first regulars to come ashore became drunk and started innumerable fights. After its first taste of the Seventeenth's liberties, even the pro-Union Flake's Daily Bulletin called for an order from headquarters placing all establishments that sold liquor off limits to the bluecoats. Two days later the regulars were at it again. This time men from the now renowned Seventeenth sharpened their expertise in street fighting by cutting up a sergeant from another outfit. Others

${ }^{8}$ McConnel1, Five Years A Cavalryman, 13, 17, italics in the original. See also, Wilson, "A Soldiex of the Texas Frontier," 86.

${ }^{9}$ It is important to remember that the Seventeenth Regiment was divided into three parts in July 1866. Thus it supplied the original. cadre of all of the infantry used in Texas, except the Fifteenth Infantry stationed at Jefferson. 
in the regiment were instrumental in starting a half-dozen fights with the departing Negro soldiers and causing a small race riot. When the city's liquor supply was declared off limits, the thirsty men broke into stores and bars at gun point and ordered dxinks for all present. "We have never had a garrison that so disgraced itself," commented Flake's, "and violated the public peace." As if the uniformed men of the Seventeenth were not enough for the town, Galveston was also plagued by scores of deserters from the regiment. ${ }^{10}$

The provost marshal's details soon cracked down on the rowdy soldiers. When two drunk men from the Seventeenth smashed store windows and refused to be arrested, a provost guard bayoneted one of them in the calf. The Army shipped habitual offenders to the Dry Tortugas but the trouble continued. In one affair, four Seventeenth Infantry soldiers demanded entrance to the Galveston Theater. When they were refused, the men threatened to use force. The theater owner asked for their orders and received expletives in return. The owner decided to admit the armed men to the show and they behaved in an orderly manner. Despite their behavior, Flake's asked that off duty soldiers not be allowed to go armed in the streets. One month later three men of the Seventeenth stabbed a Negro soldier four times after they had administered him a severe beating. Not only did the officers fail to disarm the regiment when it was off duty, but citizens living near the

10Flake's Daily Bulletin (Galveston), April 25, 27, 1866. Commanding officers were ordered never to send a soldier on detached duty without written orders. Many atrocities were committed by soldiers who claimed to be acting on verbal orders. Go 14, April 13, 1867, Printed Orders, District of Texas. 
Army's camp reported numerous stray bullets flying about their homes. The editor of the Daily News asked that hereafter the guns be pointed seaward when the men took firing practice. ${ }^{11}$

As the United States Army spread its control over the rest of the state, the problems between citizens and soldiers increased. Much of the trouble occurred when soldiers became drunk. The problem was so severe that a captain of the homeward bound Thirty-seventh Illinois Infantry prohibited the sale of liquor on board the vessel that was transporting his men. A civilian who ignored the order, was caught selling intoxicants to the soldiers and was promptly tied up by his thumbs with his toes just off the ground. When a fellow passenger protested the harshness of the punishment and accused the Illinoisans of having been drunk before boarding the ship, the irate officer sirung him up in the same manner beside the liquor salesman. 12 Drunkenness ashore was an even greater problem. Liquor was so easily obtainable that one officer asked distxict headquarters for permission to prohibit the sale of alcohol under any circumstances. In Houston a drunken soldier assaulted a policeman who was forced to shoot the assailant. The provost marshal arrested the law officer who reportedly "had a terrible time before he was released." Military officers imbibed excessively in liquors which affected the performance of their duties. General Custer's paymaster was continually drunk to the point of being completely incapacitated. In addition, the

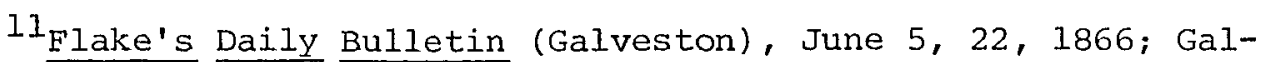
veston Daily News, February 7, March 19, April 4, 1867.

12 McConne11, Five Years A Cavalryman, 91, 118; Galveston Daily News, May 18, 1866; Flake's Daily Bulletin (Galveston), May 19, $\overline{1866 .}$ 
paymaster allowed his hotel room to be used as an officers' gambling club. When General Reynolds became commander of the Fifth Military District, he ordered reports made on all officers who frequented gambling houses or had "other vicious habits." The officers listed were to be placed before a retiring board as soon as practicable. Shortly thereafter, a captain was removed from the post at Clarksville for gambling and displaying "personal habits wholly unworthy a gentleman and a soldier."13

Other problems flowed from drink. Soldiers in Galveston robbed a store because it was out of whiskey. Further south at Victoria, Colonel I. T. Rose of the Seventy--seventh Pennsylvania, "a more despicable specimen of humanity than Santa Ana himself," commandeered a local merchant's store because he allegedly had not paid his taxes. The storeowner protested but the "investigation" took two months. When his establishment was returned to him, its supply of cigars and whiskey was missing. 14

Much of the theft perpetrated by soldiers involved food. Drab Army rations of salted beef, hardtack, and beans left a lot to be desired. On pay day those troopers who did not buy whiskey, gorged themselves on non-ration foods. Pay days were scarce in far-off Texas,

13 S. O. Young, True Stories of old Houston and Houstonians (Galveston, 1913), 45; Custer to AAG, - , 1865, in Merington, The Custer Story, 171; GO 14, October 7, 1868, Printed Orders, Fifth Military District; Maj. Lynde Catlin to AAG, September 16, 1869, Lt. Col. George P. Buel to AAG, December 15, 1869, Letters Received, Fifth Military District records.

14 Flake's Daily Bulletin (Galveston), May 2, 1866; Linn, Reminiscences of Fifty Years in Texas, 360-61. 
however, and Federal soldiers frequently rode up to a farmhouse and demanded a free meal from the farmer's wife. Theft, murdex, or rape was often a by-product of these incidents. Some soldiers were more subtle and left false requisition vouchers, a common practice when stealing cattle or horses. Any steer away from the main ranch house was slaughtered with impunity. At Weatherford a rancher shot a Sixth Cavalry corporal in command of a foraging detachment. The soldiers had been sent to purchase bacon, but the owner could not find the smokehouse key. The troopers had tried to help themselves by breaking the lock notwithstanding the verbal protests of the rancher. ${ }^{15}$ United States troops were very lackadaisical in regard to private property. This was particularly true of the volunteers who purposely destroyed property in an effort to be sent home sooner. When a house in Victoria was destroyed by soldiers, the judge and a friend went into the infamous Colonel Rose's office to complain. Rose asserted he did not care a "God dam" for the judge's allegations, and after the judge pulled a jackknife, Rose shot him in the leg and had him and his companion arrested. A barrage of complaints came from property owners who lived near Army camps or allowed their land to be used for campsites; rent went unpaid, fence rails were used for firewood, fruit trees were chopped down, and cattle and crops disappeared.

${ }^{15}$ These and similar outrages are described in McConnell, Five Years A Cavalryman, 30-33, 156; Cravens, "James Harper Starr," $\overline{304-305 ;}$ Boozer, "History of Indianola," 87; Boethel, "History of Lavaca County," 99-100; Wood, Reminiscences of Reconstruction in Texas, 13-14; North, Five Years in Texas, 188-89; Madole, "History of Salado," 28-29; Dallas Herald, June 16, 1866; The Texas News (Bonham), June 18, 1869; Capt. William C. Wilson to AAG, March 25, 1866, House Executive Documents, 40 th Cong., 2nd Sess., No. 57, 102-103; Fred Ohlenberg to AAG, November 21, 1867, Parris C. Looring to AAG, February 12, 1868, Letters Received, District of Texas records. 
Governor Hamilton ordered rowdy soldiers off the state capitol grounds, and other civil officials complained that noisy, boisterous Army guards kept county courthouses from handling government business because citizens were afraid to run the gauntlet of soldiers in the corridors. 16

Soldiers used the threat of damaging property as a convenient extralegal way to punish troublemakers and harass insulting townspeople. In september 1866 soldiers from the Seventeenth Infantry burned a section of Brenham, Texas, to the ground. In the months before the fire the troops had endured a great many insults. The local newspaper editor, a man named McGary, was the leader of the harassment. Even though he had been arrested and fined for his actions, the incidents continued. On september 7 several soldiers caused a ruckus by attending a Negro dance. When white citizens who were holding a ball nearby tried to stop the trouble, insults were traded, threats were made, and two infantrymen were shot. Later that night the soldiers returned, arrested several men, and looted a bar and a general store. The store was set afire and the conflagration spread to other buildings. A man identified as Brevet Major G. W. Smith, or more accurately, a man on the major's horse, directed the whole operation. The threat of attack from the townsmen caused the soldiers to fortify their camp. Ensuing investigations failed to solve the mystery. The Army realized

${ }^{16}$ Petition of 7 Civil Officers to Hamilton, October --, 1865, Bvt. Brig. Gen. S. D. Sturgis to Hamilton, December 23, 1865, Henry Robey to Hamilton, February 9, 1866, Governor's papers (Hamilton); Throckmorton to Robert Burnet and B. H. Epperson, December 20, 1868, Epperson papers; Throckmorton to Brig. Gen. James Oakes, May 18, 1867, Throckmorton papers; Oakes to Throckmorton, May 20, 1867, Governor's papers (Throckmorton); John Burke to AAG, July 30, 1867, Letters Received, Fifth Military District records. 
its men should be punished but there were so many conflicting stories, the matter was allowed to lapse as quietly as possible. This and other similar incidents led the detachment that was sent to Lockhart, Texas, to erect a warning sign in their tent area: "If this camp is molested, every house in the community will be burned." 17

Several months after the Brenham fire, two hundred Twenty-sixth Infantry recruits marching from Indianola to Austin endured insults and threats from sevexal armed mobs. Some bystanders even offered the soldiers whiskey in an attempt to make the men more responsive to the harassment. Especially rough treatment was reserved for the recruits' guards, ${ }^{18}$ a detachment of the Third United States Colored Troops. Finally the Negroes could stand no more and profanely told a Mrs. Oliver to keep quiet. The woman's husband wrote a letter of protest to Governor Throckmorton who forwarded the complaint to Lieutenant Colonel Samuel D. Sturgis asking that the troops' route of travel be changed. Sturgis replied that the kind of treatment endured by the recruits and their guards had led to many unfortunate incidents but he refused to order the men to change their course. Throckmorton fired back a letter which challenged Sturgis' contention. The governor

17 Most of the testimony is in House Executive Documents, 40 th

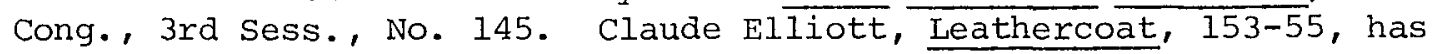
a good factual account. The unfootnoted assertion that Bvt. Maj. G. W. Smith was promoted to a higher rank by secretary of war stanton seems to be in error (155). He was transferred to seguin and placed in the Thirty-fifth Regiment when the Seventeenth was split up later that fall. Two and a half years later, with the same rank, Smith was court martialed for embezzlement and misappropriation of Freedmen's Bureau funds and acquitted. GO 101, May 18, 1869, Printed orders, Fifth Military District. For the Lockhart sign, see O'Bannion, "History of Caldwell County," 146-47.

${ }^{18}$ Guards were sent with all recruits to prevent desertion before they were assigned to actual units. 
said the soldiers had caused the ill-feeling by their own faulty conduct. 19

Occasionally the troops' resentment of Texan impudence led to murders. A convenient method of dealing with persistent troublemakers was to arrest them and then shoot them for "attempting to escape." A notorious example of this occurred in Bell County where a man named Lindley accused two men, Duncan and Daws, of hanging Unionists during the Civil War. Actually, Lindley, a horsethief, feared that Duncan and Daws had evidence that might convict him. Lindley accompanied the arresting party and, in collusion with the soldiers, murdered the men. The official report read "shot while trying to escape." Another technique was to kill fugitives and justify it by accusing them of firing first. 20

Although accusations of murder were serious affairs, some clashes between troops and civilians were quite minor. For example, the returning Confederate soldiers had few clothes except the remnants of the uniforms they had worn for the past four years. Responsible men in Indianola advised them to remove the uniform buttons so as not to give offense to the occupying Yankess. At sumpter, Texas, howevex,

19 Affidavit of Capt. George Everett, n.d., Lt. Col. S. D. Sturgis to Throckmorton, January 3, 1867, "Transcript of Records, 18381869"; Throckmorton to Sturgis, January 4, 1866, Throckmorton papers.

20 Throckmorton to Heintzelman, September 24, 1866, Throckmorton to Griffin, April 6, 1867, Throckmorton papers; GO 45, March 29, 1869, Printed Orders, Fifth Military District; H. W. Branch to AAG, February 26, 1868, Reynolds to AAG, May 29, 1868, Letters Received, Fifth Military District records; Buchanan to Pease, June 5, 1868, Letters Sent, ibid.; Griffin to Throckmorton, April 23, 1867, "Transcript of Records, 1838-1869"; O'Bannion, "History of Caldwell County," 147; Elliott, Leathercoat, 150-52; Wallace, Texas in Turmoil, 187-88. 
this precaution was not taken and when Federal soldiers clumsily tried to cut the buttons off of E. B. Robb's uniform, Robb pistolwhipped one of them. The other soldiers, not expecting resistance, scattered momentarily. Robb took advantage of the lull and tore the United states flag from the pole across the street, threw it to the ground, and stamped it into the dirt. The soldiers vowed revenge, and the townsmen armed themselves to support Robb. Fortunately the commanding officer did not pursue the matter. Those who persisted in wearing Confederate uniforms were walked about clothed in wooden barrels. The Army usually discouraged insults to the flag by marching the offender to and fro under the standard while a military band played patriotic airs. 21

The actions of the United States Army received much criticism, but there was also much praise. "The soldiers go about in a quiet home-like manner," commented the Galveston Daily News, "mix unobtrusively with the citizens, and indulge in no spread-eagle excentricities [sic]." H. H. McConnell felt that Texans and the Army got along quite well. Even as devout a sympathizer of the lost cause as James Harper starr reluctantly admitted the soldiers in Nacogdoches were well-disciplined, commanded by strict officers, "and committed few outrages upon our people." When a troop column arrived in Navasota looking for the murderers of two soldiers, they were subjected to the usual taunts and insults. A citizen wrote a letter of apology to Governor Throckmorton for the town's attitude. He explained that soldiers had never been in the area before and blamed the insults on

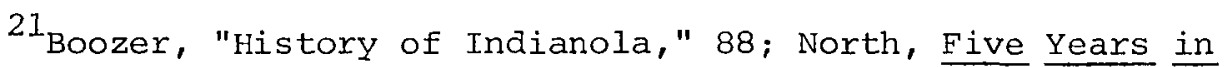
Texas, 188; Bowles, "History of Trinity County," 53-54.
} 
the town drunk who had been promptly locked up by the mayor. He also complimented the troops' bearing and discipline in a difficult situation. 22

Individual officers were commended for their conduct also.

Colonel G. W. Clark of the Thirty-fourth Iowa Infantry was well-liked in Galveston. The "present popular commander of the post" and his regiment had "behaved in such an orderly and in every way creditable manner, that we earnestly hope it may be stationed at the Post" as long as necessaxy, said a local newspaper. If Galveston had to suffer military rule, the commentary continued, "at least let it be under those we can respect." When the Seventeenth Infantry was transferred to Virginia in 1869, the Dallas Herald regretted the loss of Captain Henry Norton of Company G. "We. . commend him to our old friends in the old Dominion," said the Herald, "as a gentleman, a good officer, and beloved by our citizens. His conduct here was high-toned . . . ." John S. Ford praised Major General Daniel McCook, who was in charge of the Rio Grande Valley, for his kindness and understanding. His exemplary conduct made Texas lose sight of the fact that it had been

22 Flake's Tri-Weekly Bulletin (Galveston), June 20, 1865; Gal-

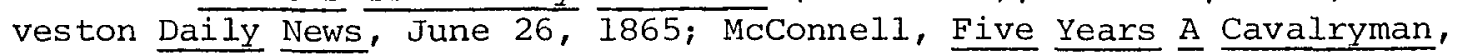
159; Cravens, "James Harper Starr," 305-306; E. D. Johnson to Throckmorton, April 27, 1867, Governor's papers (Throckmorton). For other expressions favorable to Union troop conduct, see Army and Navy Journal, $\mathrm{V}$ (May 16, 1868), 619; Boethel, "History of Lavaca County," 96-97; Marr, "History of Matagorda County," 162; Arwerd Max Moellering, "A History of Guadalupe County, Texas" (Unpublished M.A. thesis, University of Texas, Austin, 1938), 43; Memorial and Biographical History of Navarro, Henderson, Anderson, Limestone, Freestone, and Leon Counties, 460; Moore, "Anderson County During Reconstruction," 4 ; Hamilton to Johnson, August 30, 1865, Johnson papers. Corpus Christi continually tried to obtain a military post and, when one was set up, insure its permanence. See William Headen and B. B. Fly to AAG, July 20, 1868, P. Doddridge to AAG, August 7, 1869, Letters Received, Fifth Military District records. 
conquered. He governed the district "mildly and pleasantly," concluded Ford. 23

One of the most sensitive issues in the South was the use of Negro soldiers as occupation troops during Reconstruction. Although evidence of praise tendered the black units is scarce, ${ }^{24}$ they were often well-disciplined. Most white southerners, however, felt "the idea of a gallant and high-minded people being ordered and pushed about by an inferior, ignorant race" was "shocking to the senses."25

An immediate campaign was undertaken to put the "uppity," proud Negro soldiex in his place before the local colored population was infected with the same attitude. Frequent racial incidents occurred, often resulting in gun play. A Galveston man, G. A. Jones, found a Negro soldier "loitering" near his home. When the black refused to move on, Jones threatened him with his cane. The trooper reached for his gun, whereupon Jones beat a hasty retreat to his house for a revolver. The soldier was joined by a friend and both demanded that Jones come outside. Jones asked the name of their commanding officer, but was told it was "none of your d----d business." He claimed a black then pointed his gun at him causing him to fire first, dropping

23 Galveston Daily News, July 15, 1865, January 12, 1866, March 12, April 26, 1867; Dallas Herald, May 25, 1867, May 29, 1869; San Antonio Weekly Express, April 7, 1870; Ford, Rip Ford's Texas, 410-11; Hughes, Rebellious Ranger, 248.

${ }^{24}$ The only regiment to receive praise from the white Texans was the Tenth United States Colored Troops stationed at Galveston. A pro-Union newspaper asserted "it would be difficult for any of us to name a regiment that has conducted itself in a more praiseworthy manner," Flake's Daily Bulletin (Galveston), May 3, 17, 1866.

25 Bellville Countryman, August 18, 1865. Texans also feared that the black troops would "demoralize" their local Negroes, Galveston Daily News, September 18, 1865. 
the soldier with a single shot. The deputy town marshal at Jefferson shot and killed two members of the Eighteenth United States Colored Troops who were quietly eating watermelon. For no apparent reason, the peace officer first blasted them with his double-barreled shotgun and then administered the coup de grace with his pistol. In Calhoun County two black soldiers were murdered while transferring two Army horses to another post. When a black cavalryman became drunk in san Antonio and tried to ride down a white woman in the street, he was knocked from his saddle by a "volley of shots" from the sidewalk. 26 Like their white counterparts, Negro soldiers were accused of numerous crimes, the most provocative usually involving white women. A black followed one white woman home in Galveston but he disappeared as she entered the house and reported the incident to her husband. Another woman drove off a colored soldier with a pistol when he tried to break into her home one night. Trespassing complaints were common. The usual excuse for both white and black soldiers was that they had "orders" to pass. In Brownsville a Negro trooper was refused a haircut in a barbershop. The soldier drew a revolver and threatened the barber and two customers. "G-d d--n you," he swore, "I'll blow the top of your head off, too." He was reported to his superior who had him bucked and gagged as punishment. The local editor claimed the incident was "typical of the demands for equality and heightening of

\section{Flake's Daily Bulletin (Galveston), February 25, April 30,} 1866; Capt. A.V. Loweli to AAG, September 3, 1866, Sheridan to Rawlins, October 1, 1866, House Executive Documents, 40th Cong., 2nd Sess., No. 57, 32, 126; Griffin to Throckmorton, January 21, 1867, "Transcript of Records, 1838-1869"; Throckmorton to Griffin, January 30, February 18, 1867, Executive Correspondence; Thompson, "Reconstruction Days in San Antonio," 28-29. 
racial tensions" in the area. 27

Whenever a Negro regiment entered an area, the population invariably traced the majority of all thefts and vandalism to it. In Indianola the black soldiers were reported to be unwelcome. The Negroes had sacked a nearby farm and threatened the owner's life. Fortunately an officer had intervened to prevent further incidents. In the lower Rio Grande Valley an angry letter from "Veritas" accused "nigger troops" of numerous assaults and robberies. The correspondent hoped the blacks would be transferred to another area. 28

Because the Negro troops operated under the double liability of the blue uniform and their race, they sometimes reacted harshly to the insults and discrimination shown them. The colored soldiers often sided with the freedmen in asserting their rights. At Clarksville, policemen who were arresting a freedman were surrounded by a group of Negroes. The mob claimed that "no d----d white man should arrest colored people any more." The white police fled to a nearby store. When the Negro soldiers arrived, they attacked the white lawmen. The ensuing gunfight left one white policeman and one Negro soldier wounded. In spite of the efforts of the troop commander, the black troopers later returned and patrolled the streets making threats and saying the day of white rule had ended. The Negro soldiers at Galveston were involved in numerous racial shootings and riots. In Brownsville

\section{Flake's Daily Bulletin (Galveston), February 25, July 29,} 1866; Houston Telegraph, May 9, 1866; Brownsville Daily Ranchero, June $6,1867$.

${ }^{28}$ Boozer, "History of Indianola," 87-89; Brownsville Daily Ranchero, March 4, 1868. "Veritas" was granted his wish when the Forty-first (Colored) Infantry was transferred to the California Trail shortly thereafter. 
a patrol of black troops was fired on by a drunken white peace officer. the Negroes returned fire and killed the policeman and a barkeeper. The town mayor later exonerated the soldiers from any blame. ${ }^{29}$

The colored troops and freedmen also received numerous racial affronts from white Yankee soldiers who seemed to dislike Negroes as much as the Texans did. White soldiers often broke into Negro shacks and beat the occupants. The Seventeenth Infantry fought pitched battles with black soldiers leaving both sides with a number of casualties. Threats were commonly exchanged on the streets, and southern juries staunchly found white soldiers guiltless in most racial cases taken to court. In one instance a white trooper demanded a dollar from a Negro "for services rendered in emancipation." The Negro indignantly refused and the two were prevented from coming to blows only by the intervention of passersby. 30

There were even cases where white Texans intervened to prevent further attacks on Negroes by United States soldiers. At Hempstead a

${ }^{29}$ Flake's Daily Bulletin (Galveston), January 11, February 27, 28, March 3, May 4, 1866; San Antonio Express, May 24, 1866; Reynolds to AAG, January 19, 1867, House Executive Documents, 40th Cong., 2nd Sess., No. 57, 34; Reynolds to Rawlins, January 19, 1867, Johnson papers. Other incidents included blatant murder attempts by Negro soldiers. See, e.g. , the William walker case in which two colored soldiers murdered a hired man near Victoria, Texas, Throckmorton to ------- , September 24, 1866, Executive Correspondence; Throckmorton to Heintzelman and James P. Kean, September 25, 1866, Throckmorton papers; Throckmorton to Sheridan, November 8, 1866, Capt. Charles w. Peters to AAG, November 29, 1866, AAG to Throckmorton, December 15, 1866, all in Governor's papers (Throckmorton). See also Galveston Daily News, June 9, 1866; Brownsville Daily Ranchero, February 10, 1870.

${ }^{30}$ Daniel Thompson (colored) to Hamilton, August 26, 1865, Governor's papers (Hamilton); Flake's Daily Bulletin (Galveston), January 17, April 26, 1866; Galveston Daily News, April 26, July 5, 1866, March 19, June 1, 1867; Throckmorton to Griffin, March 5, 1867, Executive Correspondence. Negroes occasionally attacked white soldiers also. See Flake's Daily Bulletin (Galveston), March 30, 1866 . 
vigilante committee killed two soldiers of the Ninety-ninth Illinois Infantry for committing "nameless outrages" on a Negro woman. When black prisoners rioted in the Galveston jail, members of the Fortyeighth Ohio Infantry Battalion were called in to restore order. One black was killed and two wounded by a bayonet charge. The angered white soldiers then attempted to beat the other prisoners severely, but "the sheriff interposed his authority" to stop the affray. 31

While more atrocities were recorded than examples of cooperation this is to be expected because Texans were always suspicious of the conduct of Reconstruction soldiers. Hence they played up the dramatic and tended to ignore the commonplace. But the multiplicity of incidents was important because it helped those who opposed the purposes of Reconstruction to swing public opinion to their side. This was poignantly illustrated in a letter from Dr. W. A. Brown to Governor Hamilton. Dr. Brown, a Unionist from Cunningham, was complaining about an Army wagon driver who left a sick man soaked with discharges of blood and vomit in a muddy field. "This case has created any amount of excitement here," protested Brown, "and is just the kind of food for the minds of the secessionists." 32

${ }^{31}$ Spindler, "History of Hempstead and the Formation of waller County," 419; Flake's Daily Bulletin (Galveston), January 12, 1866.

${ }^{32} \mathrm{Dr}$. W. A. Brown to Hamilton, November 8, 1865, Governor's papers (Hamilton). In fairness to the Army it should be pointed out that both the Texas Rangers and the Confederate army committed fewer but similar depredations. These organizations, however, faced a different political situation; therefore, their offenses were more easily forgotten. See Barrett, "Federal Outposts in Texas," 88-89. For the conduct of the Confederate Army, see Lois Ellsworth, "San Antonio During the Civil War" (Unpublished M.A. thesis, University of Texas, Austin, 1938), 48-55. 
One of the most vexing and persistent issues that faced nineteenth century Texas was the Indian problem. When Sam Houston became the first president of the Republic in 1836, he instituted a policy of peace and fair dealing with the Indians. Unlike many of his constituents, he opposed the use of roving ranger companies which sought out and destroyed any Indian village on the frontier. Despite Houston's peace policy, the Indian attacks continued as the advancing settlers encroached on the tribes' hunting areas. Dissatisfied with Houston's approach, the Texans elected Mirabeau B. Lamar as governor. Lamar believed the settlers and Indians could never live in peace and he was determined to drive every tribe he could from the confines of the state. His program, however, cost a great deal of money and quite a few more lives than Houston's. War weariness helped reelect Houston in 1841, and the Indians quickly took advantage of the change in policy and sued for peace. Anson Jones, the last president of the Republic, followed Houston's peace policy but depredations and conflict continued. 1

After the Mexican War the defense of the frontier was assumed by the United States Army. The military sent the First Infantry, half

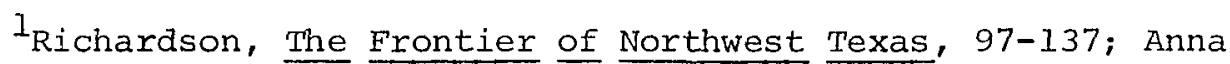
Muckleroy, "The Indian Policy of the Republic of Texas" (Unpublished M.A. thesis, University of Texas, Austin, 1919), 82-84, 86, 122-23, 127, 164-65. Lamar had the Cherokee, Shawnee, and Kickapoo removed to an area north of the Red River. 


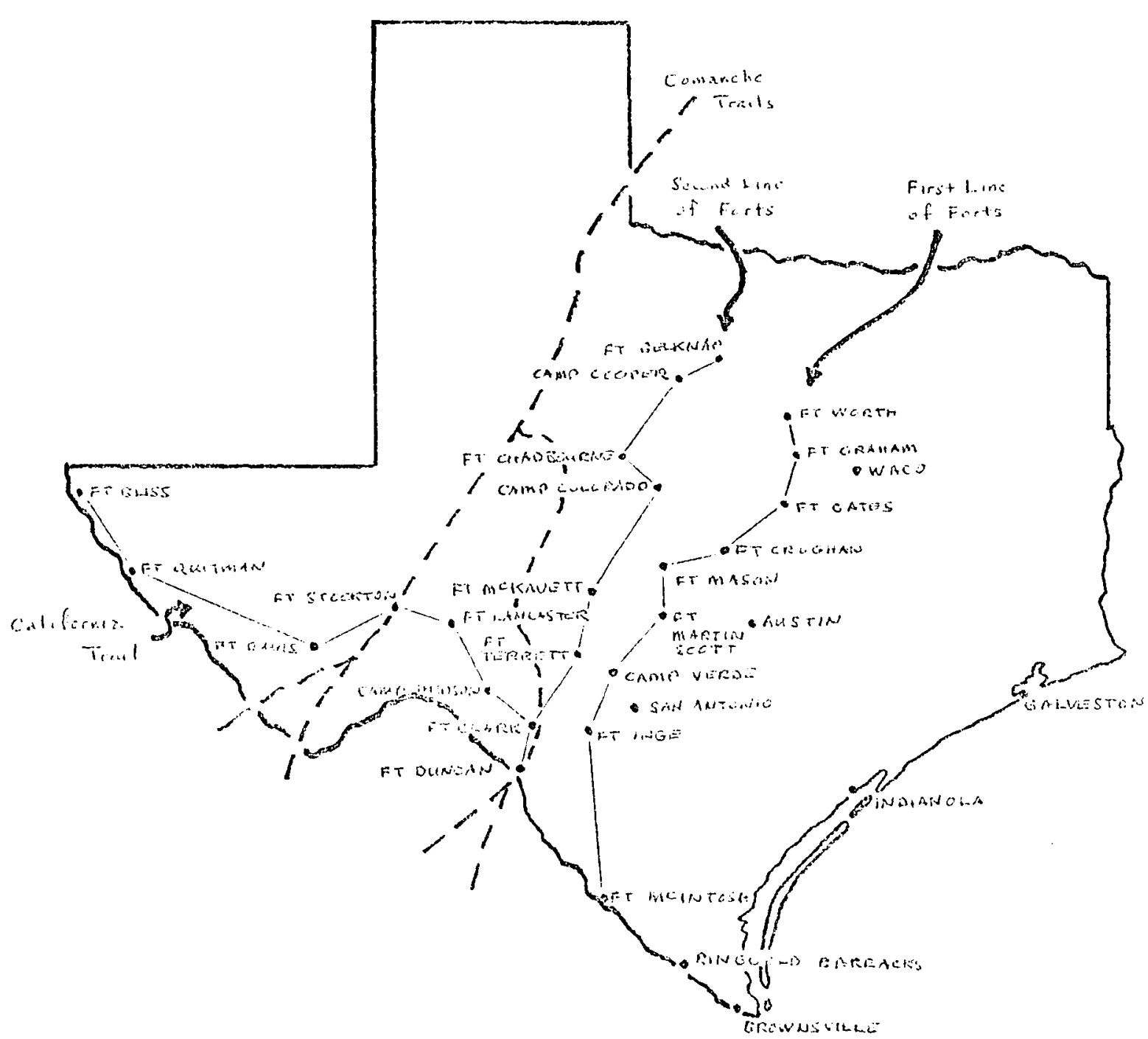

Mapte. Pre-Civil War Fronticer 
of the Third Infantry, six companies of the Second Dragoons, and two batteries of artillery to Texas. ${ }^{2}$ These troops were stationed along the Rio Grande and in two lines of forts along the frontier. The first line of forts was constructed in 1848 and 1849 and stretched from the Mexican border to the upper Trinity River. ${ }^{3}$ By 1851, however, the advancing frontier had passed them, necessitating the erection of a second line fifty to one hundred miles west of the first. ${ }^{4}$ In order to stop the Comanche raids in Mexico and in an effort to improve Mexican-American relations, a series of posts was built in the mid1850's. These garrisons, Fort Lancaster, Fort Davis, and Fort stockton, along with Fort Quitman (1858) and what is now Fort Bliss (1848), also protected the Butterfield mail route to California. 5

2 Thomas Heskill Johnson, "Relations With the Indians on the Texan Frontier, 1858-1859" (Unpublished M.A. thesis, University of Texas, Austin, 1935), 3-4; Clara Koch, "Federal Indian Policy in Texas, 1845-1860" (Unpublished M.A. thesis, University of Texas, Austin, 1922), 97-98.

3 Rupert N. Richardson, et al., Frontier Forts of Texas (Waco, 1966), xi; M. L. Crimmins, "The First Line of Army Posts Established in West Texas in 1849," West Texas Historical Association, Year Book, XIX (1943), 121-27; Francis Paul Prucha, A Guide to the Military $\overline{\text { Posts of }}$

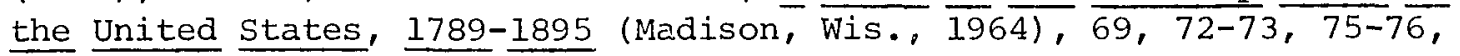
$\overline{80}, \overline{85,90}, \overline{117}$.

${ }^{4}$ Richardson, et al., Frontier Forts of Texas, xi-xiii, xvii, 5-6, 64, 135-36; Johnson, "Relations With the Indians on the Texan Frontier," 4-6; Prucha, A Guide to the Military Posts, 60, 62, 64, 66, 88-89, 91, 111; Earl Burk Braly, "Fort Belknap of the Texas Frontier," West Texas Historical Association, Year Book, XXX (1954), 83-84; M. L. Crimmins, "Fort McKavett, Texas," Southwestern Historical quarterly, XXXVIII (1934-35), 28.

5 Richardson, et al., Frontier Forts of Texas, 27, 113; Prucha, A Guide to the Military Posts, 61, 70, 84, 100, 109; Henry T. Fletcher, "old Fort Lancaster," West Texas Historical and Scientific society, Publications, No. 44 (December 1932), 35; M. L. Crimmins, "The Border Command at Fort Bliss," ibid., No. 1 (December 1926), 16; Elsie Mitchell Rushmore, The Indian Policy During Grant's Administrations (Jamaica, New York, 1914), 59. 
Despite the construction of the fort lines, the raids into the settlements persisted. The well-mounted tribesmen easily escaped the pursuing infantry and the very small number of cavalry. Disillusioned with state and Federal efforts to end the conflict, the harassed German settlers, who often bore the brunt of the attack, negotiated and signed their own peace treaty with the Comanche. Although there were violations of the terms, the Germans were generally left alone. ${ }^{6}$ other Texans demanded more emphatic action, and the state government organized several punitive expeditions against the tribes in the late 1850's. These campaigns only led to retaliatory raids against the settlements. In reprisal, the western settlers demanded and secured the forced removal of all Indians living near Camp Colorado and Camp Cooper on the state reservations to an area north of the Red River. By 1860 these events pushed Indian hostility to a new high. 7

The secession of Texas from the Union meant evacuation of the western parts of the state by the United States Army and the assumption of frontier defense by Confederate forces. Because of the demands of the Civil War, however, these Confederate troops were transferred to other commands. ${ }^{8}$ Texans realized they would have to provide for their

${ }^{6}$ Richardson, et al., Frontier Forts of Texas, xi; Rudolph Leopold Biesele, "The Relation Between the German Settlers and the Indians in Texas, 1844-1860," Southwestern Historical Quarterly, XXXI (1927-28), $122,125,128-29$.

${ }^{7}$ Richardson, et al., Frontier Forts of Texas, xv-xvi; Johnson, "Relations With the Indians on the Texan Frontier," 9-46, 49, 52, 112, 114, 128; Koch, "Federal Indian Policy in Texas," 186; Barrett, "Federal Outposts in Texas," 27-28, 68, 82; Mildred P. Mayha11, "Camp Cooper-First Federal Fort in Texas to Fall, 1861, and the Events Preceding Its Fa11," Texana, V (1967), 317-18.

8Mayhall, "Camp Cooper," 317-42; Ruckman, "The Frontier of Texas During the Civil War," 9-23; W. C. Holden, "Frontier Defense in Texas 


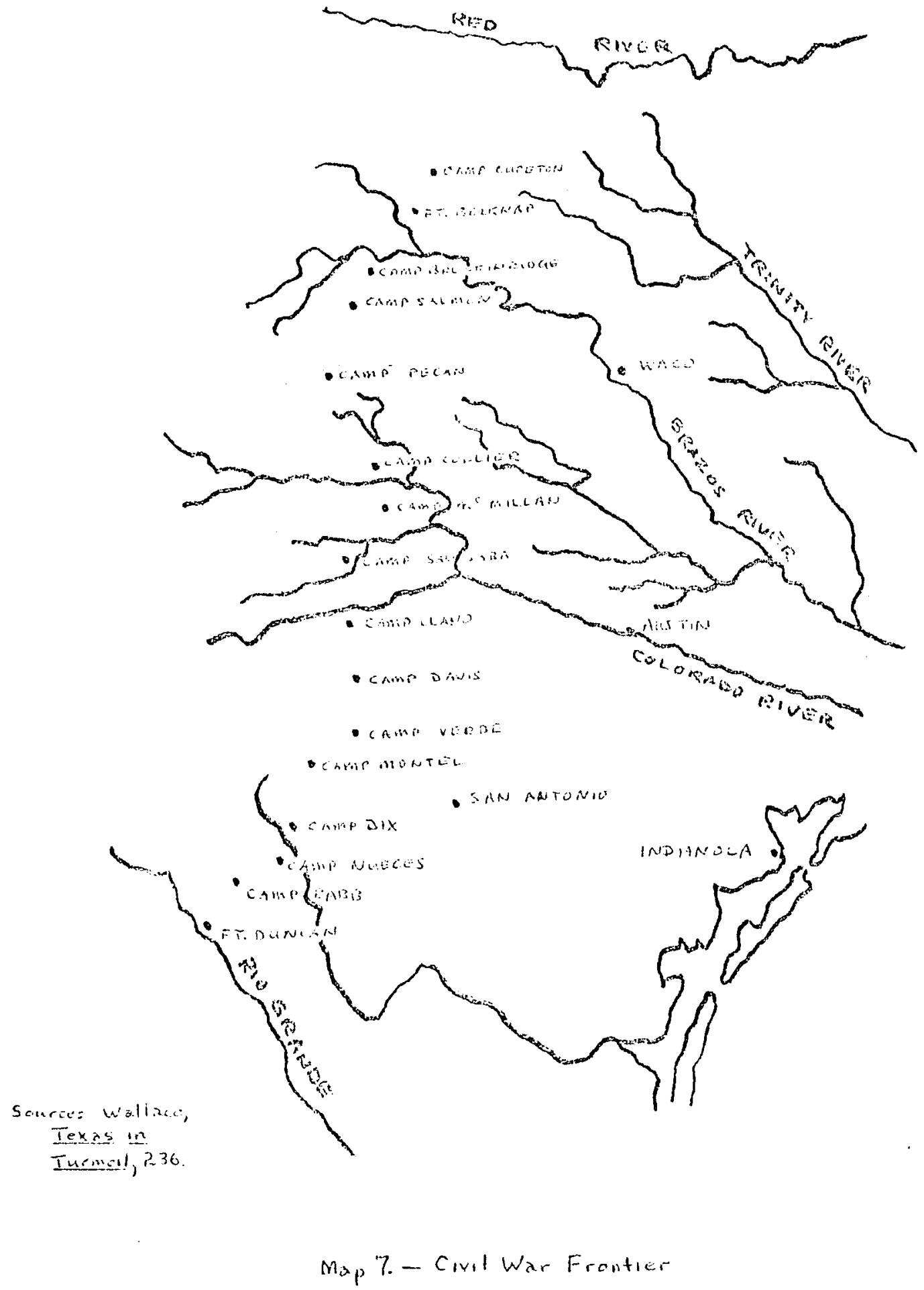


own frontier defense, and the Frontier Regiment was organized in late 1861. Increased expenses necessitated the transfer of the regiment to Confederate service as the Forty-sixth Texas Cavalry in 1864, and the burden of frontier defense was passed on again to local militia companies. ${ }^{9}$ The continued reorganization and diminishing numbers of frontier soldiers resulted in increased Indian attacks which reached a peak in 1864. During that year, several hundred Comanche made the famous Elm Creek raid and, along with the Kiowa, defeated an expeditionary force from New Mexico at Adobe Walls in the Panhandle. Another unfortunate incident occurred in January 1865 when a detachment of state troops attacked a band of peaceful Kickapoo who were migrating to Mexico. As the angry Indians beat off the attack, one more hardy enemy was added to the forces striking the worn-out frontiersmen. 10

During the Civil War," West Texas Historical Association, Year Book, IV (1929), 16-18; Donald W. Whisenhunt, "Fort Richardson: Outpost on the Texas Frontiex," Southwest Studies, V (No. 4, 1968), 5; Wallace, Texas in Turmoil, 234-37; Fletcher, "Old Fort Lancaster," 37.

${ }^{9}$ Many of the Frontier Regiment's recruits were Germans or Unionists who used this service to avoid Confederate conscription. See Heintzen, "Fredericksburg in Civil War and Reconstruction," 20-36. See also, Richardson, The Frontier of Northwest Texas, 238-49; Ruckman, "The Frontier of Texas During the Civil War," 20, 30, 62, 68, 71, 74-75, 84, 94, 96-97; Holden, "Frontier Defense in Texas During the Civil War," 19-26; Whisenhunt, "Fort Richardson," 5-6; Wallace, Texas in Turmoil, 337-43; Kenneth Neighbours, "Elm Creek Raid in Young County, 1864," West Texas Historical Association, Year Book, XL (1964), 83-89.

10 Richardson, The Frontier of Northwest Texas, 249-50; Ruckman, "The Frontier of Texas During the Civil War," 102, 118; Holden, "Frontier Defense in Texas During the Civil War," 26-30; Ben o. Grant, "Explorers and Early Settlers in Shackleford County," West Texas Historical Association, Year Book, XI (1935), 30; Marilynne Howsley, "Forting Up on the Texas Frontier During the Civil War," ibid., XVII (1941), 71-76; "Action at Dove Creek, Texas, January 8, 1865," O. R. , XLVIII, Pt. 1, 26-30; W. C. Holden, "Frontier Defense, 1865-1889," Panhandle-Plains Historical Review, II (1929), 43-45. 
When General Kirby Smith surrendered the Trans-Mississippi region to the Yankees in May 1865, the defense of the frontier ceased altogether. Anticipating further onslaughts, the worried settlers left their farms to "fort up" for mutual protection. Some historians estimate that only one-fifth of the population stayed behind, moving the line of settlement back nearly one hundred miles. Recent research, however, finds that the population may have merely shifted into the areas containing the improvised "forts."11

Although there was a period between 1865 and 1867 when military protection was nearly non-existent, adequate numbers of Union soldiers were forwarded to the frontier as soon as possible after the end of the Civil war. The biggest obstacle to placing troops in the western posts was the demobilization of the volunteers. These men were already close to mutiny in their resentment at being sent to eastern Texas, and General Sheridan expected to receive their muster-out orders that winter. To garrison the forts with these men was to court trouble and unnecessary expense; hence, Little Phil relied on periodic patrols to the west. ${ }^{12}$ He also asked Grant to forward the regular cavalry assigned to Texas but by the time it arrived, it was November. Sheridan felt it was too late in the year to garrison the western forts and Grant agreed. $^{13}$

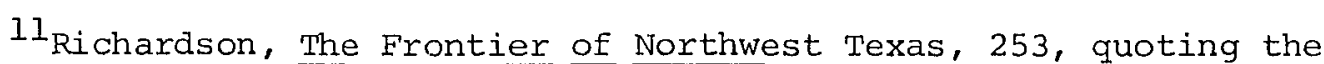
Waco Register, April 21, 1866; Holden, "Frontier Defense, 1865-1889," 44. See also, Lambert, "Defense of the Indian Frontier," 93; Carrie J. Crouch, Young County: History and Biography (Dallas, 1937), 55; W. C. Kimbrough, "The Frontier Background of Clay County," West Texas Historical Association, Year Book, XVIII (1942), 122, 125-26.

12 Army officers were very economy-minded in the nineteenth century because Congress was tight with its appropriations.

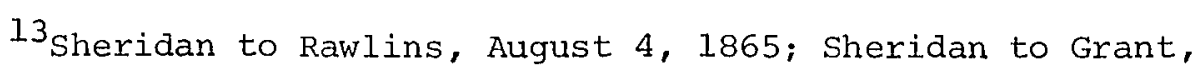


Throughout 1865 and 1866 the western settlers sent numerous petitions to both state and Fedexal authorities, demanding protection from assaults by white brigands as well as Indians. ${ }^{14}$ In response to these complaints, A. J. Hamilton asked General Wright to send soldiers to the threatened western counties. Wright replied that he had no authority to change any post on his own initiative but he had recommended to Sheridan that half of the Sixth Cavalry be sent north to Jacksboro, Weatherford, and Sherman to counter the expected spring onslaught of the Comanche. Little Phil indicated his desire to help, but between the muster-out of the volunteers and the enlistment and training of new recruits, he had his hands full. Sheridan realized that any delay would leave inadequate time to establish the proper logistical support necessary to supply and rebuild the western forts

September 20, 1865, Grant papers; Sheridan to Merritt, August 17, 1865, Sheridan to Grant, September 22, November 3, 1865, Sheridan papers. Winter weather seriously hampered movement on the plains from November until April or May. Whisenhunt, "Fort Richardson," 11.

${ }^{14}$ For examples of complaints about Indian raids, see the letters from the following persons to Governor A. J. Hamilton: H. J. Thompson, August 9, 1865, Thomas U. Toler, August 30, 1865, Petition from Citizens of Parker, Stephens, Wise, and Jack Counties, September 5, 1865, Petition from Wise County, September 9, 1865, Judge Thomas Buchholz and others, September 23, 1865, D. O. Norton, October 17, 1865, and Petition from Parker, Palo Pinto, Stephens, Young, Jack, Wise, Clay, Montague, and Archer Counties to Major F. W. Emery, undated, 1865, al1 in Governor's papers (Hamilton). See also, J. W. Lane to Hamilton, September 25, 1866, House Executive Documents, 40th Cong., 2nd Sess., No. 57, 42; J. W. Light to R. W. Black, October 17, 1866, R. W. Black papers, Archives, University of Texas; Petition from Citizens of Wise County, July 27, 1866, in Annie Charlotte Terrill, "A Calendar of the Memorials and Petitions to the Legislature of Texas, 1861-1877" (Unpublished M.A. thesis, University of Texas, Austin, 1936), 28. A good reference to these and other petitions is Dorman $H$. Winfrey and James M. Day (eds.), The Indian Papers of Texas and the Southwest, 1825-1916 (4 vols., Austin, $1 \overline{966)}, I \bar{V}, 87-2 \overline{96}$. See also, J. M. Franks, Seventy Years in Texas . . . (Gatesville, Texas, 1924), 32-34, 41-43, 61-63, 65-66, 68-69, 70-71, 80-81, 89-94; Wilbarger, Indian Depredations in l'exas, passim; Ida Lasater Huckabay, Ninety-four Years in Jack County (Austin, 1949), 156. 
that year but he could do little else. ${ }^{15}$

In August 1866 Throckmorton took over the statehouse as the newly elected state executive. Throckmorton had been a Unionist in 1861 but, unlike Hamilton, he had supported his state when it seceded. He served as a brigadier general during the war and took a special interest in frontier defense. In fact, when news of Kirby smith's surrender arrived, Throckmorton was in the Indian Texritory signing a peace treaty with the Comanche. Therefore, it was quite natural to expect this frontiersman to take a different approach to state government than had Hamilton who was more interested in Reconstruction and the interior. ${ }^{16}$

A week after his inauguration Throckmorton wrote General Wright and asked him to send troops to the west. He also asked Wright to bring the matter to Sheridan's attention in New Orleans. ${ }^{17}$ On september 25, 1866, he wrote Wright's successor, Heintzelman, to complain of continued raids and to ask that a post be estabiished at the mouth of the Big Wichita River. Evidently the governor felt that the Army would not act because he telegraphed detailed information on some recent attacks to President Johnson. Secretary of War Stanton replied

15 Wright to Hamilton, March 3, 1866, Governor's papers (Hamilton); Wright to AAG, March 2, 1866, Sheridan to Grant, May 4, 1866 , House Executive Documents, 40th Cong., 2nd Sess., No. 57, 21-23, 36.

${ }^{16}$ A good sketch of Throckmorton's life is in Thrall, A Pictorial History of Texas, 625-26. See also, Elliott, Leathercoat, passim; and Holbert, "The Public Career of . . . Throckmorton," passim. One of Hamilton's last reports to President Johnson did contain an appeal for two mounted regiments. See Hamilton to Johnson, March 1, 1866, Johnson papers.

17 Throckmorton to Wright, August 17, 1866, Executive Correspondence. 
for the President saying that the matter was under consideration. 18 Sheridan was not entirely unresponsive to the reported depredations. In early september 1866, on his own initiative, he ordered the Fourth Cavalry transferred to Camp Verde and Fort Martin Scott near Fredericksburg. He did not send troops elsewhere because he stated there were no other official reports of raids. Governor Throckmorton quickly informed the general that the Comanche to the north were the main cause for distress. He asked that posts be established to block the trails into Texas from Indian Territory. At the same time he promised Sheridan that Negroes would receive justice and fair treatment, which would lessen the need for soldiers in the interior. Sheridan forwarded the letter to Washington but in an endorsement he stated that he felt Throckmorton had exaggerated the Indian problem, and he doubted that the governor could guarantee the impartiality of Texas officials toward the freedmen. Sheridan said he would set up more frontier posts the following spring. 19

The governor's complaint to President Johnson had struck a sympathetic note, however, and Grant was asked to do something to solve the problem. Grant informed Sheridan that evidence amassed by Throck-

18 Throckmorton to Heintzelman, September 25, 1866, Throckmorton papers; Throckmorton to Johnson, September 26, 1866, Stanton to Throckmorton, September 28, 1866, House Executive Documents, 40th Cong., 2nd Sess., No. 57, 40-43. Throckmorton also wrote Johnson on August 25, 1866, Throckmorton papers.

${ }^{19}$ Sheridan to Rawlins, April 26, 1866, House Executive Documents, 40 th Cong., 2nd Sess., No. 57, 35; Sheridan to Throckmorton, September 3, 1866, Throckmorton to Sheridan, September 18, 1866, Sheridan papers. These units may not have arrived at Camp Verde or Fort Martin scott until October 1866, but it was not Throckmorton's pleas alone that brought this about as claimed by Harold B. Simpson, "Fort Mason," in Richardson, et al., Frontier Forts of Texas, 168. 
morton made the problem look quite serious. He ordered an investigation and told Sheridan to break up the interior posts, if necessary, to ensure proper frontier defense. Grant wanted to make certain there was no excuse available to justify raising and employing state troops. 20 Sheridan immediately informed Grant that he had ordered eleven companies of the Sixth Cavalry north to Jacksboro. This meant his entire cavalry force of twenty-one companies was sent to the west with the exception of two troops at Brownsville and the one troop on orderly service in New Orleans. 21

Sheridan also indicated that the Second Battalion of the Seventeenth Infantry inad been moved to Austin for possible frontier duty, and that the Ninth Cavalry, a recently recruited Negro regiment, was coming to Texas. Sheridan hinted that if the state behaved itself and did not protest Reconstruction unduly, this black unit would probably be sent to the west. The race-conscious Texans would then be spared the burden of occupation by colored soldiers. Sheridan also mentioned that he expected another Negro outfit, the Forty-first Infantry, to be placed along the frontier sometime in $1867 .^{22}$

20 Sheridan to Grant, October 11, 1866, Grant to Sheridan, October 11, 1866, House Executive Documents, 40th Cong., 2nd Sess., No. $57,40-41,43$.

${ }^{21}$ Sheridan to Heintzelman, October 15, 1866, Sheridan to Rawlins, October 15, 1866, Sheridan papers; Sheridan to Rawlins, October 16, 1866, Grant papers. See also, Throckmorton to David G. Burnet and Oran M. Roberts, November 16, 1866, Epperson papers; Sheridan to Throckmorton, November 3, 1866, Governor's papers (Throckmorton).

${ }^{22}$ Sheridan to Throckmorton, October 16, 1866, Heintzelman to Throckmorton, October 26, November 13, 1866, Governor's papers (Throckmorton): Throckmorton to Sheridan, November 22, December 11, 1866, Throckmorton to Maj. George A. Forsyth, October 29, 1866, Throckmorton to Heintzelman, November 19, 1866, Throckmorton papers; Sheridan to Throckmorton, January 18, 1867, "Transcript of Records, 1838-1869"; 
Although Throckmorton continued to flood military headquarters with accounts of Indian depredations, ${ }^{23}$ Sheridan never received official reports of the Comanche raids and continued to suspect that they were exaggerated or false. The general believed that the freighting companies who held Army supply contracts magnified and possibly invented depredation stories to clear the way for bigger contracts to supply additional frontier garrisons. $^{24}$ He felt that the settlers also exaggerated actual attacks to secure posts in their areas in order to build up the economy. Little Phil's misgivings were not helped any when General wright informed him that the frontier issue was being

C. B. Comstock to Sheridan, January 21, 1867, Grant papers; Sheridan to Rawlins, November 14, 1866, O.R., XLVIII, Pt. 1, 301-302. One should remember that just because the regular cavalry arrived in November 1865, this did not mean that the regiments were ready to take the field. In addition to the usual logistical problems (Sheridan was still trying to obtain enough cavalry horses in October 1866, Sheridan to Throckmorton, October 25, 1866, Governor's papers [Throckmorton]), a large percentage of these regulars were recruits. In the infantry, this was also true, but an infantryman was easier to train as their three-year enlistment implied. A cavalryman, however, served for five years. The first two years were spent in training. See w. H. Carter, Horses, Saddles, and Bridles (Leavenworth, Kansas, 1895), 15-87. By stationing his cavalry on the frontiex in the fall of 1867, Sheridan merely waited the necessary length of time to make his force effective. It is possible that the Fourth Cavalry had more veterans in 1865 than the Sixth Cavalry and, thus, was able to take the field first in Septembex 1867. See Carter, From Yorktown to Santiago, 132 . For mention of large numbers of recruits for both regiments, see Sheridan to Throckmorton, November 3, 1866, Governor's papers (Throckmorton); AGO to AAG, Fifth Military District, September 26, 1867 , Letters Received, Fifth Military District records. The Ninth (Colored) Cavalry took the field in 1867 only a year after it was officially organized.

23 Throckmorton to Getty, October 3, 1866, Throckmorton to Heintzelman, October 22, December 3, 1866, Throckmorton to CO, District of Texas, December 6, 1866, Throckmorton to Griffin, December 11, 1866, Throckmorton papers.

${ }^{24}$ Sheridan to Rawlins, October 15, 1866, House Executive Documents, 40th Cong., 2nd Sess., No. 57, 44. 
used to trick the Army into withdrawing soldiers from the interior. ${ }^{25}$ The worst of Sheridan's suspicions seemed to be confirmed when a staff officer uncovered a false massacre story in the Camp Verde area. ${ }^{26}$ In addition, Throckmorton seemed to be using the supposed Indian raids as an excuse to raise a one-thousand-man force for "frontier defense." Throckmorton apparently was convinced that neither the Federal government nor the local Army command would provide sufficient soldiers for the West. 27 Since Throckmorton did not give the Army time to prove its intent on the frontier question, sheridan suspected these men were a threat to the national government's control of the state. Even though state militia companies had been informally sanctioned by Governor Hamilton during the summer of 1865 and used ever since, ${ }^{28}$ the new plan proposed by the state legislature and

${ }^{25}$ Griffin reported that anti-Negro atrocities were so bad in the summer of 1867 that troops might have to be withdrawn from the frontier to stop their reoccurrence. Griffin to Sheridan, July 20, 1867, Sheridan papers.

26 Sheridan to Rawlins, Septembex 6, 1866, Sheridan to Grant, October 12, 1866, January 25, 1867, House Executive Documents, 40th Cong., 2nd sess., No. 57, 34, 36, 43-44; sheridan to Rawlins, september 8, 1866, Sheridan papers; Sheridan's report, November 14, 1866, O....., XLVIII, Pt. 1, 301 .

27 Both Throckmorton and Hamilton made independent efforts to negotiate for the release of goods captured by the Kickapoo. See J. K. Zumwelt to the Governor, July 8, 1865, Governor's papers (Hamilton); [R. W, Black] to Sheridan, October 6, 1865, Throckmorton to Black, December 6, 1866, [R. W. Black] to Throckmorton, January 6, 1867, R. W. Black papers. The Army turned over all recaptured property to its original owners. See Throckmorton to Stanton, March 9, 1867, Throckmorton papers; Circ. 8, March 25, 1867, Printed Orders, District of Texas.

28 T. S. Lyons and others to Hamilton, August 5, 1865, Charles I. Jordan to Hamilton, September 5, 1865, Hamilton to Frank Carter, October 5, 1865, Governor's papers (Hamilton). 
Throckmorton envisioned an official and more permanent force of state troops. When Sheridan received the governor's letter suggesting the possibility of raising Texas volunteers, he forwarded it to Washington noting his disapproval of the plan. A week later Throckmorton sent President Johnson a similar report but he never obtained an answer. On september 29,1866 , the persistent state executive formally asked for Sheridan's approval of the troops and mentioned that Indian attacks were increasing; he also sent a similar note to secretary of War stanton. Little phil again referred the request to higher headquarters and later wrote Grant that he feared the state soldiers were being used as a guise to remove the Army from the interior and to compromise Reconstruction efforts. Sheridan said he had already sent the cavalry out to handle the Indian problem and since "the troops raised in Texas would be of the element which fought against the government," he believed such a unit was not needed. 29

Throckmorton quickly protested Sheridan's refusal to accept the Texas volunteers. The governor insisted he had no ulterior motives in mind but that he merely wished to defend the state. Meanwhile Grant notified Sheridan that he agreed that there were enough regulars to handle the job in Texas. To appease Throckmorton, Little Phil promised "as much protection as we possibly can give the frontier will be cheerfully given," but he could not set up the western garrisons until

29 Throckmorton to Sheridan, September 18, 1866, Sheridan to Grant, October 3, 1866, Sheridan papers; Throckmorton to Sheridan and Johnson, September 26, 1866, Throckmorton to Stanton, september 29, 1866, House Executive Documents, 40th Cong., 2nd Sess., No. 57, 40-42; Throckmorton to Sheridan, September 29, 1866, Throckmorton papers; Sheridan to Throckmorton, October 1, 1866, Governor's papers (Throckmorton). 
the next spring. 30 The wily Throckmorton was in no mood to wait and decided on a new course of action. He wrote General Heintzelman at Galveston and said he would not raise the state troops if the Army would send more men to the west immediately. He also commanded state officers to organize their companies informally in spite of Sheridan's orders to the contrary. Little Phil had assumed the matter had been settled until he obtained a copy of the waco Register which contained a notice of a meeting of armed men interested in becoming part of Throckmorton's one thousand volunteers. Sheridan's indignation at the governor's impudence boiled over in a raging anger. He notified Grant that he would settle the problem and once again acidly and emphatically refused to allow Throckmorton to call up local volunteers in any form. 31

30 Throckmorton to Sheridan and Grant, October 6, 1866, Throckmorton papers; Grant to Sheridan, October 8, 1866, Grant papers; Grant to Throckmorton, October 20, 1866, House Executive Eocuments, 40 th Cong., 2nd Sess., No. 57, 40, 45.

${ }^{31}$ One of the problems with the state volunteers was that some of them had served in Duff's Partisan Rangers during the war. This unit was noted for the atrocities committed against Unionists. See R. W. Black to Throckmorton, [August 1866], Throckmorton papers; Forsyth to Sheridan, November 2, 1866, House Executive Documents, 40th Cong., 2nd Sess., No. 57, 130. Throckmorton had some companies organized, but not actively, in spite of Sheridan's orders. See his letters to Capt. John Sansom, November 16, 1866, Capt. G. B. Pickett, November 21, 1866, Capt. ---- Durand, December 7, 1866, Throckmorton papers. The information in the text is found in Heintzelman to AAG, October 25, 1866, Telegrams Received, Department of the Gulf records; Sheridan to Grant, October 29, 1866, Grant papers; Sheridan to Grant, November 20, 1866, Sheridan papers; Sheridan to Throckmorton, November 11, 1866, House Executive Documents, 40th Ccigy., 2nd Sess., No. 57, 129. The use of state troops continued to be debated throughout the Reconstruction period. General Reynolds authorized their use for a brief time but Washington countermanded his orders. The Twelfth Legislature raised some mounted companies in the early $1870^{\prime} \mathrm{s}$, but Federal opposition and insufficient funds severely limited their capabilities. See AAG to Reynolds, February 8, 1868, Letters Sent, Fifth Military District records; Lt. A. Malloy to AAG, May 25, 1868, Letters Received, 
To satisfy Grant's earlier request for a complete inquiry,

Sheridan sent one of his most trusted aides, Major George A. Forsyth, to the northwestern frontier to investigate the Indian forays. Forsyth arrived in Galveston in November 1866 where he spoke with General Heintzelman before proceeding to Austin to see the governor. Throckmorton was very friendly and gave Forsyth complete cooperation in his investigation. As he left for waco, the major informed Sheridan that he had no solid evidence yet, "but I am convinced that many of the people who are moving in from the frontier are doing it to better their [economic] condition, and not from any fear they may have of the Indians." Ten days later, he wrote his superior again, this time noting that the newspapers in Texas were highly inaccurate in their reporting and tended to exaggerate their news items. ${ }^{32}$

After traveling as far north as Weatherford, 33 Forsyth returned and submitted his full report. The major had found several instances

District of Texas records; Reynolds to AAG, June 17, 1868, Letters Sent, ibid.; Reynolds to AGO, March 4, 1870, Letters Sent, Fifth Military District records. See also, San Antonio Daily Express, March 15, 1870, in Carl Coke Rister, "Early Accounts of Indian Depredations," West Texas Historical Association, Year Book, II (1926), 23-24; Frances Skinner, "The Trial and Release of Satanta and Big Tree: State-Federal Relations During Reconstruction" (Unpublished M.A. thesis, University of Texas, Austin, 1937), 35-36; Nunn, Texas Under the Carpetbaggers, 38, 197-98; Ruckman, "The Frontier of Texas During the Civil War," 129-30; A. E. Skinner, "Forgotten Guardians: The Activities of Company 'C, Frontier Forces, 1870-1871," Texana, VI (1968), 107-21.

${ }^{32}$ Sheridan to Rawlins, October 20, November 11, 1866, Forsyth to Sheridan, November 2, 1866, House Executive Documents, 40 th Cong., 2nd Sess., No. 57, 44, 129-30; Throckmorton to -.--, October 29, 1866, Throckmorton papers.

${ }^{33}$ Carl Coke Rister, The Southwestern Frontier, 1865-1881 . . (Cleveland, 1928), $102 \mathrm{n} .1 \overline{01}$ asserts that Forsyth on $\overline{1 y}$ went to Waco. In his report, Forsyth said he went to Weatherford. See Forsyth to AAG, December 16, 1866, House Executive Documents, 40th Cong., 2nd Sess., No. 57,46 . 
in which Indians had raided settlements and believed there had been others. The biggest problem he discovered was that the frontiersmen were not the brave, hardy settlers depicted even then in the American myth. Instead, the whole frontier was permeated with a fear beyond comprehension. At Fort Belknap the local settlement was "pretty thoroughly stampeded, scarcely daring to venture away from the post." 34 The cavalry commander at Jacksboro told the major that those settlers who suffered raids were too afraid to leave their homes to report them. By the time he was informed of an attack, his patrols were already one or two days behind the Indians and it was impossible to catch up to them on the "worthless horses" at his disposal. Forsyth also reported that even though the Indians did commit murder when the opportunitȳ presented itself, their primary goal was to obtain horses and salable goods, not to kill. Local citizens felt the raiders came from Indian Territory and they wanted the Army to attack the villages there in reprisal, said Forsyth. In conclusion, the major recommended that a post be established near old Fort Belknap to extend Army protection to the people there. 35

Dissatisfied with Forsyth's report, Throckmorton sent out a printed form to all county judges asking for a complete account of all Indian depredations in theix judicial districts. ${ }^{36}$ The replies to

34 Fort Belknap was not garrisoned by Federal troops at the time of Forsyth's journey. It was one of a series of civilian "forts" where settlers had gathered for mutual protection.

${ }^{35}$ See Forsyth's report, December 16, 1866, House Executive Documents, 40th Cong., 2nd Sess., No. 57, 46-48. Tt is possible that Forsyth, as subordinates sometimes do, wrote what he believed sheridan wanted to hear.

${ }^{36}$ Printed form in Throckmorton papers. 


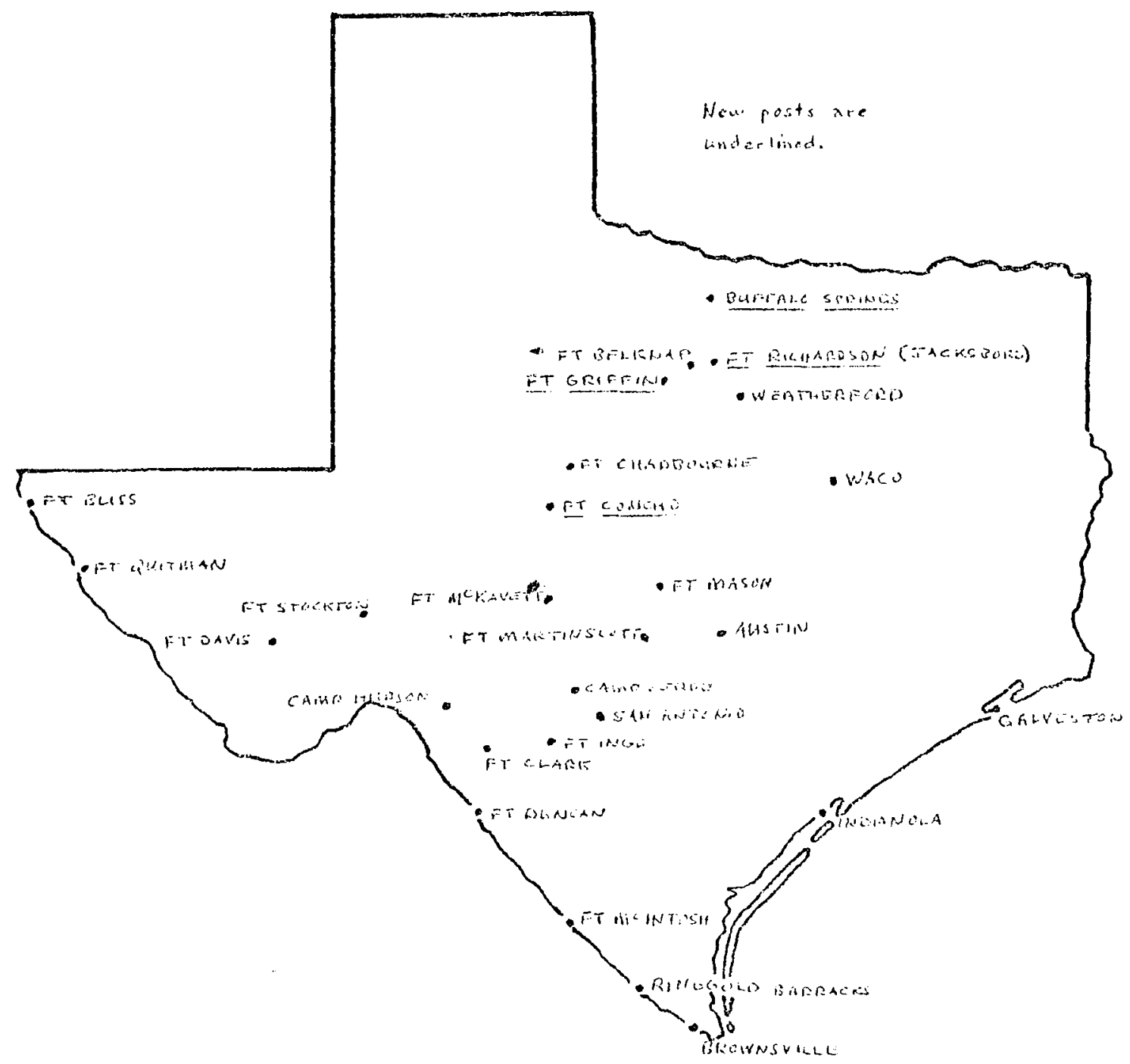

Map 8.- Recenstinction Frostier 
this circular enabled the governor to disclose to secretary of war Stanton in August 1867 that since the end of the Civil War, one hundred sixty-two persons had been killed by Indians, forty-three captured, and twenty-four wounded. An estimated 31,000 cattle, 2,800 horses, and 2,400 sheep and goats had been stolen during the same period. 37

-...... Once again Throckmorton wrote to Galveston and urged that more forts be established. ${ }^{38}$

Sheridan's promise to set up the frontier forts was nearly destroyed by the national political situation in March 1867. Texas and Louisiana were placed in the Fifth Military District commanded by General Sheridan with headquarters at New Orleans. Because of the confusion caused by the enactment of the Reconstruction Acts, Grant ordered Sheridan to postpone his impending trip to Texas and stay in New Orleans until the Reconstruction process was running smoothly in Louisiana. At first Sheridan thought the congressional legislation would force General Griffin to reduce the frontier garxisons. Little Phil soon changed his mind, however, and told Griffin to set up more western posts without delay, especially the camp at Buffalo Springs. During the summer of 1867 four new forts were established in Texas, and General Griffin promised to send one more regiment to the west if Texans would act in a responsible manner toward the Reconstruction

${ }^{37}$ Throckmorton to stanton, August 5, 1867, ibia.

38 AAG, Texas to AAG, Fifth Military District, August 24, 1867, Letters Received, Fifth Military District records. See also, Ruckman, "The Frontiex of Texas During the Civil War," 119-20; Holden, "Frontiex Defense, 1865-1889," 46-48; Joseph I. Lambert, "The Defense of the Indian Frontier of Texas By the U. S. Army" (Unpublished M.A. thesis, Saint Mary's University, San Antonio, 1948), 93-95. 
TABLE 3

REOCCUPATION OF TEXAS FORTS

\begin{tabular}{|c|c|c|c|}
\hline Year & Rio Grande & West & California Trail \\
\hline 1865 & $\begin{array}{l}\text { Brownsville } \\
\text { (May 30) } \\
\text { Ringgold Barracks } \\
\text { (June 24) } \\
\text { Ft. McIntosh } \\
\text { (Oct. 23) }\end{array}$ & & Ft. Bliss ${ }^{\mathrm{a}}$ \\
\hline 1866 & & $\begin{array}{l}\text { Jacksboro (May) } \\
\text { Camp Verde (Fall) } \\
\text { Ft. Martin Scott } \\
\text { (Oct. 18) } \\
\text { Ft. Clark (Dec. 12) } \\
\text { Ft. Mason (Dec. 25) }\end{array}$ & \\
\hline 1867 & & $\begin{array}{l}\text { Ft. Inge (Jan. 31) } \\
\text { Ft. Belknap } \\
\text { (April 28) } \\
\text { Ft. Chadbourne } \\
\text { (May 25) } \\
\text { Ft. Concho (Dec. 4) }\end{array}$ & $\begin{array}{l}\text { Ft. Davis (June 29) } \\
\text { Ft. Stockton } \\
\qquad(\text { July 7) }\end{array}$ \\
\hline 1868 & Ft. Duncan (May 28) & $\begin{array}{c}\text { Ft. McKavett } \\
(\text { April 1) }\end{array}$ & Ft. Quitman (Jan. 1) \\
\hline
\end{tabular}

a First occupied June 1863 by lst Calif. Vol. Inf.

$\mathrm{b}_{\text {Later abandoned; garrison moved to Buffalo Springs which was }}$ abandoned also; garrison moved to Ft. Richardson, Nov. 20, 1867.

${ }^{C}$ Abandoned; garrison moved to Ft. Griffin, July 31, 1867. 
TABLE 4

NUMBERS OF TROOPS STATIONED IN TEXAS

\begin{tabular}{cccccc}
\hline Year & Interior $^{\mathrm{a}}$ & \multicolumn{3}{c}{ West } & Total \\
\cline { 3 - 5 } & Rio Grande $^{\mathrm{b}}$ & Frontier $^{\mathrm{d}}$ & 764 & Total & $\begin{array}{c}\text { Tote } \\
\text { State }\end{array}$ \\
\hline 1860 & $25000^{\mathrm{e}}$ & $25000^{\mathrm{e}}$ & Misc. Patrols & $25000^{\mathrm{e}}$ & $51000^{\mathrm{e}}$ \\
1865 & $1800^{\mathrm{e}}$ & $1500^{\mathrm{e}}$ & $1600^{\mathrm{e}}$ & $3100^{\mathrm{e}}$ & $4900^{\mathrm{e}}$ \\
1866 & 1840 & 875 & 1880 & 2755 & 4595 \\
1867 & 1620 & 863 & 3192 & 4055 & $5675^{\mathrm{f}}$ \\
1868 & 1707 & 929 & 1976 & 2905 & 4612 \\
1869 & $510^{9}$ & 1189 & 3041 & 4230 & 4740 \\
\hline
\end{tabular}

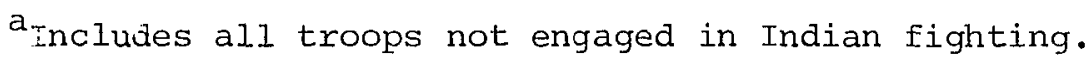

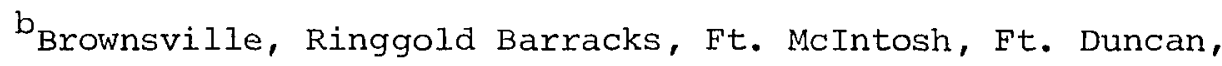
San Ignacio, Lake Trinidad.

Cuacksboro, Weatherford, Buffalo Springs, Camp Verde, Camp Hudson, and Forts Richardson, Martin Scott, Clark, Mason, Inge, Belknap, McKavett, Griffin, Chadbourne, Concho, Bliss, Davis, Stockton, and Quitman.

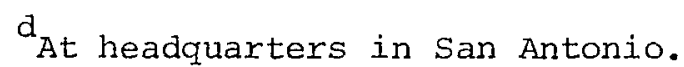

Estimated; no accurate figures are available.

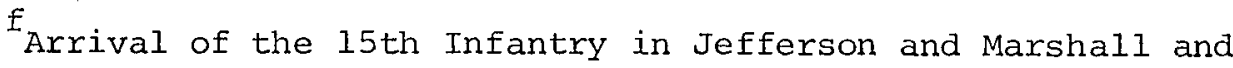
shift of the 4th Cavalry, 6th Cavalry, and 26th Infantry to the west.

$g_{\text {San Antonio, Austin, Waco. }}$ 
of the interior. ${ }^{39}$

That fall President Johnson relieved Sheridan of command of the Fifth Military District. His replacement, General Hancock, believed the Army should stay out of state politics; he turned his attention to the frontier where he erected new posts and moved some of the older ones to new locations. ${ }^{40}$ In addition, he recommended that a telegraph system be established to connect the forts and make for a more efficient response to reported Indian raids. At the same time he shifted the Twenty-sixth Infantry to the Mexican border and transferred the Forty-first (Colored) Infantry from the Rio Grande Valley to the California Trail. This removed the last Negro soldiers from the more populated areas of the state. Hancock also withdrew elements of the Seventeenth Infantry from the interior and sent them to the northwestern frontier. 41

Hancock's action brought just over 3,000 troops to the frontier, a new high. In fact, this was the largest number of men stationed in the western part of the state until 1873 and was above the average for

${ }^{39}$ Sheridan to Grant, March 14, April 12, 1867, Grant to Sheridan, March 15, 1867, Johnson papers; AAG to Griffin, March 23, 1867, Sheridan papers; Sheridan to Griffin, August 27, 1867, Telegrams Sent, Fifth Military District records; Griffin to Pease, September 12, 1867, Letters Sent, District of Texas records.

40 Many Texas forts lacked an adequate water supply. The available sources were often too brackish for use. The garrisons at Buffalo Springs and Fort Belknap were moved to Forts Richardson and Griffin respectively. Richardson, The Frontier of Northwest Texas, 274.

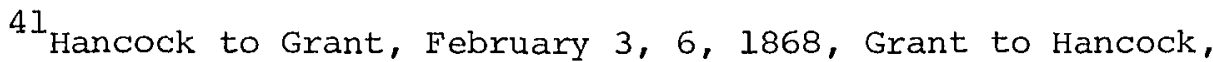
February 3, 1868, Grant papers; So 27, February 6, 1868, Printed Orders, Fifth Military District; SO 36, February 25, 1868, Printed Orders, District of Texas; Hancock to Reynolds, March 14, 1868, Telegrams Sent, Fifth Military District records; Richardson, et al., Frontier Forts of Texas, xix. 
the entire period prior to the 1874 defeat of the Comanche at Palo Duro Canyon. The only year the troops dropped significantly below the 3,000 mark was 1869, when General Canby reduced the western garrisons to 1,976 men in order to combat increasingly "disloyal" acts in eastern Texas. 42

Two factors are of prime importance in determining why it took until the late 1870's to defeat the marauding bands of Indians. The first was the Federal government's attitude toward the Indians. In 1865 the United States had just concluded the bloodiest war in its history. Americans were tired of conflict, and the government's Indian policy reflected this. In 1865 the Johnson administration contracted with several church groups to maintain Indian schools and to teach agricultural skills to the tribesmen. Shortly thereafter, a peace commission was formed to contact the plains tribes, negotiate, and sign treaties with them. When General Grant was elected to the presidency he agreed to let the Society of Friends administer several Indian agencies as an experiment. Other Protestant denominations also demanded and received agencies. ${ }^{43}$

The appointment of missionaries as Indian agents and the use of the peace commissioners reflected Congress' exasperation with the whole Indian question. In effect, the men on Capitol Hill dumped the

42 It is doubtful whether or not the Confederacy ever succeeded in placing more than 2,000 men on the frontier as the Federals had in 1860. See Wallace, Texas in Turmoil, 234-40. See also, so 13, January 16, 1869, Printed Orders, Fifth Military District; Holden, "Frontier Defense, 1865-1889," 52-53; McConnel1, Five Years A Cavalryman, 212.

${ }^{43}$ Henry E. Fritz, The Movement for Indian Assimilation, 18601890 (Philadelphia, 1963), 56, 62, 73, 76, 79; Loring Benson Priest, Uncle Sam's Stepchildren: The Reformation of United States Indian Policy, 1865-1887 (New Brunswick, New Jersey, 1942), 29, 31. 
whole problem in the churches' laps. The "Quaker Peace Policy," as it came to be called, operated on the principles that it would be cheaper to feed the Indians than to fight them and that the churches could put a stop to the inefficiency and corruption within the agencies and civilize the wild tribes at the same time. Unfortunately, trouble began when Congress refused to provide sufficient funds to implement the program. As a result the starving, angry warriors felt they had been double-crossed by the peace commissioners. Because control of Indian policy-making fluctuated at this time between the war Department and the Interior Department, there was no supervision over agents or annuities. The "Quaker Peace Policy" also regarded the Indians more as the missionaries' responsibility than as "wards of the government amenable to the authority of the United states and entitled to just, humane and enlightened treatment. " 44

Army officers had misgivings about this policy from the first since they felt the Indians had to be forced onto reservations by military defeat. Otherwise reservations became havens which supplied the war parties and provided safety when the Indians were pursued. 45 There was some justification in the Army's position. The "feed 'em not fight 'em" idea had originally been developed by Thomas Fitzpatrick, a mountain man once associated with the old Rocky Mountain Fur Company. But titzpatrick had qualified his theory by stating that two alter-

${ }^{44}$ Fritz, Indian Assimilation, 80, 86. Fritz feels that the peace policy was an "intelligent attempt" to deal with the frontier problem, but Priest more correctly calls it a "product of confusion," Priest, Uncle Sam's Stepchildren, 183. See also, Rushmore, The Indian Policy of Grant's Administrations, $39,55,61$.

45 Fritz, Indian Assimilation, 120, 125, 129, 133; Priest, Uncle Sam's Stepchildren, 69-70. 
natives existed. The first was to feed and supply the Indians well enough to make raiding unprofitable. The other alternative was to make raids suicidal. He also said that there was no intermediate choice: only one of the two extremes would be successful. Because the government tried to compromise, Texas suffered the consequences. 46 The second factor that enabled the Indian marauders to survive so long was the nature of Army tactics. The basic symbol of military power on the plains was the fort, but the great distance between forts and the relative immobility of the garrisons which were often infantry, made the protection given by forts more psychological than real. No matter how many forts were established or how strategically they were located, the soldiers invariably arrived too late to help the threatened homestead. The effect was lots of pursuit with few results. ${ }^{4}$

In an attempt to intercept the raiders before they arrived at the settlements, both United States and Confederate officers tried a system of offensive patrols before the full moon when the Comanche traditionally struck. At first they were successful and many Indian war parties were stopped. ${ }^{48}$ The raiders, however, soon learned to

46 Robert M. Utley, Frontiersmen in Blue: The United States Army and the Indian, 1848-1865 (New York, 1967), 55-57. An especially stinging indictment of the peace policy is in Skinner, "The Trial and Release of Satanta and Big Tree," 172. See also, Nunn, Texas Under the Carpetbaggers, 177-83.

47 It was not uncommon for the forts to be eighty-five miles or more apart, nor for the soldiers to have to travel that far to the site of a raid. See John Fletcher, "Fort Phantom Hill," Texas Military History, III (1963), 161; Richardson, et al., Frontier Forts of Texas, vii, xv; Utley, Frontiersmen in Blue, 53; Holden, "Frontier Defense, 1865-1889," 54; Wallace, Texas in Turmoil, 249; and Ruckman, "Frontier Defense of Texas During the Civil War," 75.

${ }^{48}$ For examples of victories over the Indians, see Throckmorton to Grifin, January 2, 1867, Throckmorton papers; GO 5, January 29, GO 40, November 21, 1867, Printed Orders, District of Texas; GO 13, 
avoid the patrols. In the fall of 1865 Sheridan revived a pre-war idea and sent out large mobile columns which stayed out for weeks on end; these too had poor results. ${ }^{49}$ As far as the Indians were concerned, the Federal government failed to show its authority until 1871 when the Kiowa chiefs, Satanta and Big Tree, were arrested and tried. 50 The citizens of Texas vented their anger freely at the Army's failure to crush the Indian forays and accused the Federal government of being influenced by too much "milk and water sentiment" in its frontier policy. ${ }^{51}$ The universal solution for Texans was to yell for the Texas Rangers. 52 These state soldiers were good fighters who did not bother with the niceties of war (taking prisoners, not torturing

October 5, 1868, GO 164, September 11, GO 186, October 28, 1869, Printed Orders, Fifth Military District.

49 Ruckman, "Frontier Defense of Texas During the Civil War," 174; Wallace, Texas in Turmoj.1, 237-38, 245; Carl Coke Rister, Fort Griffin on the Texas Frontier (Norman, 1956), 68; Utley, Frontiersmen in Blue, 54; Dallas Herald, September 9, 1865; GO 177, HQ, Fourth Cavalry, San Antonio, December I, 1866, "Transcript of Records, 18381869."

${ }^{50}$ Carl Coke Rister, "The Significance of the Jacksboro Indian Affair of 1871," Southwestern Historical Quarterly, XXIX (1925-26), 199-200. A third Kiowa chief, Satank, was "killed while trying to escape" on the way to the trial. Texas historians often unfairly accuse Governor Davis of poor frontier defense because he failed to support the Ranger program. See McKay, "Texas Under the Regime of E. J. Davis," 48; Frances Skinner, "The Trial and Release of Satanta and Big Tree," 41; A. E. Skinner, "Forgotten Guardians," 107, 121. Webb, Texas Rangers, 219, 307, gives undue credit to the Rangers for ending the Comanche menace.

${ }^{51}$ Flake's Daily Bulletin (Galveston), April 3, 1867, quoted in Rister, "Early Accounts of Indian Depredations," 20. Frontiersmen had the same feeling throughout the West. See Fritz, Indian Assimilation, $109-19$.

52 The standard account of the Rangers gives the impression they could do no wrong. See Webb, Texas Rangers, passim. See also, Huckabay, Ninety-four Years in Jack County, 104; Johnson, "Relations with the Indians on the Texan Frontier," 47; Koch, "Federal Indian Policy in Texas," 99 . 
captives, or respecting reservation sanctuaries) that often hindered Army operations. The Rangers produced the dead Indians the frontiersmen liked to see. They also knew the western terrain better than the soldiers and, more importantly, they struck the Indians where any guerrilla-type fighter is hurt the most--at home. The Army used these same tactics during the 1874 campaign in which Mackenzie defeated the Comanche at Palo Duro Canyon. Combined with a new total war concept and winter campaigning, the Army quickly reduced the powerful tribes' will to fight and brought them to the reservations. 53 Poorly mounted, short of essential equipment, armed with inferior single-shot carbines, forced to cope with a niggardly Congress that denied them sufficient money to correct these ills, and with no formal strategic or tactical doctrine, the Army truly did an amazing job in subduing the plains Indians. 54

In their zeal to document the suffering of the western settlers, Texas frontier historians tend to ignore the fact that the frontiersmen were involved in the Reconstruction process in addition to their concern with the Indian problems. Although western Texas had few Negroes, several instances suggest the effects of the era were more

${ }^{53}$ Utley, Frontiersmen in Blue, 127, 345-48; Rister, The Southwestern Frontier, 121, 123; Henry W. Barton, "The United States Cavalry and the Texas Rangers," Southwestern Historical quarterly, IXIII (1959-60), 495-510. The problem was compounded because there were no tactical essays on how to fight Indians beyond some preliminary statements by Col. Randolph B. Marcy and Brig. Gen. Philip St. George Cooke. See R. B. Marcy, Thirty Years of Army Life on the Border (New York, 1866), 67-68; Otis E Young, The West of Philip St. George Cooke, 1807-1895 (Glendale, Calif., 1955), 321; Ut ley, Frontiersmen in Blue, 57. See also, Matloff (ed.), American Military History, 305-306.

54 Richardson, The Frontier of Northwest Texas, 279; Utley, Frontiersmen in Blue, $\frac{57}{349}$. 
definitely felt than supposed. 55 Interspersed among the complaints of Indian raids were numerous letters denouncing "rebel officials" who refused to uphold law and order. At first glance, one might suspect the settlers were using the one method of ensuring Army protection. Reliable Unionists, however, made these persistent complaints in a vociferous manner that suggests sincerity. The letters reported vigilante raids on Loyalists, the destruction of American flags, and the refusal of local officials to protect Unionists. 56

Frontier fort commanders had to handle Reconstruction duties in addition to their normal routine. The officer in charge of Fort Richardson sent in recommendations for offices, made appointments, and supervised elections. The Fort stockton commander handled similar duties in the extensive Presidio County area. Registration records had to be kept in most of the western counties. ${ }^{5}$ Although Ilano County was "comparatively free from the effects of reconstruction," as was

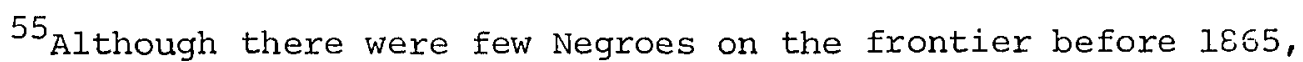
there are indications that their numbers increased after the war. For example, El Paso's black population in 1860 was 29, but by 1870 it was 306. Nancy Lee Hammons, "A History of El Paso County" (Unpublished M.A. thesis, University of Texas, El Paso, 1942), 103.

${ }^{56}$ Petitions of Citizens of Parker, Stephens, Wise, and Jack Counties, September 5, 1865, Sheriff D. B. Lucky to Hamilton, October 16, 1865, D. O. Norton to Hamilton, October 17, 1865, B. F. Barkley to Hamilton, October 30, 1865, Governor's papers (Hamilton); J. W. Robbins and others to Hamilton, February 10, 1866, James Bedford and others to Hamilton, February 13, 1866, Lucky and Norton to CO, Post of Austin, February 13, 1866, House Executive Documents, 40 th Cong., 2nd Sess., No. 57, 24-26; Hamilton to Sheridan, March 19, 1866, Sheridan papers.

${ }^{57}$ GO 185, October 18, 1869, Printed Orders, Fifth Military District; CO, Fort Richardson to AAG, October 15, 1869, Letters Received, Civil Affairs, Fifth Military District records; Assistant Secretary of Civil Affairs to James Brown, September 6, 1869, Secretary of Civil Affairs to Thomas Johnson, October 9, 1869, Letters Sent, ibid. 
its neighbor Gillespie, the latter actively supported the state Republican party until the mid-1870's. 58

Party battles were viciously fought in frontier areas. In the lower Rio Grande Valley, United States soldiers were accused of breaking into registration records and smashing ballot boxes to influence the vote. 59 out in far off $\mathrm{El}$ Paso, political infighting was especially vigorous. As early as 1862, when the California Column reoccupied the area for the Union, Confederate sympathizers were indicted and their property confiscated and sold. Although most of the property was eventually returned to the original owners, El Paso citizens split into two groups--the ex-Confecerates represented by Joseph W. Magoffin, and the Republicans led by W. W. Mills. Magoffin received Hamilton's sanction to organize the area, but the local military commander, Captain David H. Brotherton, refused to recognize Magoffin's authority. Brotherton instead allowed Mills, President Lincoln's Collector of Customs, to establish a Republican administration. ${ }^{60}$ By skillfully registering and manipulating the Latin vote in the county, Mills installed himself and his fellow carpetbaggers in an 1866 election. 61

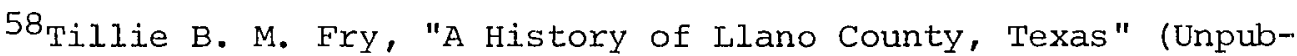
lished M.A. thesis, University of Texas, Austin, 1943), 47; Heintzen, "Fredericksburg in Civil War and Reconstruction," 80.

${ }^{59}$ Charles King to AAG, August 4, 1868, Letters Received, Fifth Military District records.

${ }^{60}$ Brotherton was able to defy Hamilton because of the geographical location of El Paso. Because it was so far west, it was located in the Military Command of New Mexico, which effectively removed Brotherton from Hamilton's immediate contact.

${ }^{6} 1_{\text {Citizens of }} \mathrm{El}$ Paso to Hamilton, May 10, 1866, J. W. Magoffin to Hamilton, December 6, 1865, May 27, 1866, Governor's papers (Hamilton); Jack C. Vowell, Jr., "Politics at El Paso, 1850-1920" (Unpublished M.A. thesis, University of Texas, E1 Paso, 1952), 46-51; Hammons, 
By the time of the 1868-1869 state convention, Mills had

married A. J. Hamilton's daughter and become a moderate Republican. This caused the El Paso party to split. Also, Mills' attempt to control salt beds near town was used against him by his opponents. This hurt him in the 1869 election but he still managed to secure a seat as state representative. Governor Davis ensured his decline by throwing patronage to the Radicals, and the state legislature refused to seat Mills because of election irregularities, 62

The El Paso situation is indicative of the complexity of Texas frontier history during Reconstruction. Texas historians are inclined to soundly condemn the Army for its failure to defeat the Indians sooner, and they blame the Army for meddling in local politics to the exclusion of defending the state from the frontier foravs. ${ }^{63}$ In so

"El Paso County," 98-101, 104-105; Owen White, Out of the Desert: The Historical Romance of El Paso (E1 Paso, 1923), 66-67, $\overline{75}$; William w. Milis, EI Paso, A Glance at Its Men and Contests for the Last Few Years.. (Austin, 1871), $\overline{1-11}$.

${ }^{62} \mathrm{CO}$, Fort Bliss to $\mathrm{AAG}$, December 25, 1869, Letters Received, Civil Affairs, Fifth Military District records; Vowell, "Politics at El Paso," 52-59.

63 For example, Wallace, Texas in Turmoil, 246, 248, claims the Fourth Cavalry did a much better job in Texas than did the Sixth Cavalry, which he accuses of being lax in defending the frontier against the Comanche. Wallace erroneously asserts that the Sixth was full of recruits, "many of whom were raw, inexperienced Negro troops." According to the law of July 28, 1866, the Sixth Cavalry was a lily-white regiment with no Negro members except possibly a cook or two. U. S., Statutes at Large, XIV, 332. Holden, "Frontier Defense, 1865-1889," 49, correctly remarks that both regiments were composed of raw recruits who were unfamiliar with Indian fighting. McConnell, Five Years A Cavalryman, 26, tells how the recruits for both regiments counted off by twos at Galveston to determine their duty stations. Wallace's criticism may stem from the fact that the Sixth Cavalry was quite active in Reconstruction work in addition to Indian fighting. Because of its role in combatting pro-southern outlaws, supervising elections, and assisting tax collectors, "the Sixth Cavalry was the most criticised [regiment] in Texas," says Whisenhunt, 
doing, these historians seem to see Texas history in a vacuum devoid of the important Reconstruction issues that dominated the nation's political scene after the war. Certainly General Sheridan and the District of Texas officers were involved with the Reconstruction problem, and this prevented them from rendering their full attention to the Indian attacks. It must be remembered, however, that the Army had a dual role to perform in Texas. True, part of this role was the defense of the state's frontier, but Texas had recently engaged in a conspiratorial act of rebellion with ten other former states. The country's leaders rightfully deemed the unsolved problems resulting from that deed the most important issues facing postwar Americans. The Comanche, Kiowa, Apache, and Kickapoo did not threaten the very structure of the nation. The South had posed such a threat and Congress feared she still might.

The frontier problem was not ignored by the Army as some Texas historians would have us believe. It was handled concurrently with Reconstruction; neither could command the Army's exclusive attention. In their haste to condemn the Army's Reconstruction role, Texas historians leave themselves open to the same criticism Sheridan bluntly cast at state authorities in 1866: "It is strange that over a white man killed by Indians on an extensive frontier the greatest excitement will take place, but over the killing of many freedmen in the settlements, nothing is done." 64

"Fort Richardson," 16. The real difference between the Fourth and Sixth Cavalry was that the Sixth was not led by a frontier hero like Ranald Mackenzie.

64 Sheridan to Rawlins, November 14, 1866, …… XLVIII, Pt. I, 301. 
XIV. BEYOND THE BOUNDS OF TRUTH AND RIGHT

The readmission of Texas to the Union in the spring of 1870 legally completed Military Reconstruction. The blacks were registered to vote and guaranteed their political and civil rights, and a loyal state administration had taken over. Theoretically there was no longer any need for the Army's services in civil affairs and the troops were rapidly shifted to frontier posts. Elements of military rule lingered on, however, because the Davis government could never command sufficient votes to stay in power.

The Radicals' fear of submitting to another election after their narrow victory in 1869 was evident when the legislature granted Governor Davis vast appointive powers to fill local offices and bypass the need for interim elections. ${ }^{1}$ The usefulness of the power of appointment had already been well demonstrated by Reynolds. The legislature also postponed the state election scheduled for November 1871 for one year which further isolated the Radicals from the white electorate. ${ }^{2}$ Even Morgan C. Hamilton, whom the Radicals elected to the U. S. Senate in 1869, publicly refused to endorse the election delay. Angered by his defection, the party leaders decided to replace him with a more reliable man. Theorizing that Morgan Hamilton had not

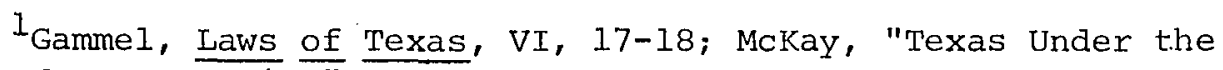

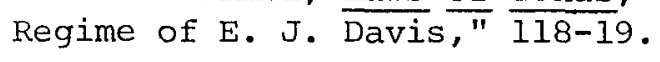

2 Nunn, Texas Under the Carpetbaggers, 27. 
been legally elected because he had been chosen before Congress

readmitted Texas as a state in March 1870, the state legislature certified Reynolds' election instead. It was quite natural for them to turn to Reynolds, the man who ensured their control of the state in the first place. Congress, however, refused to go along with the Texas Radicals and seated Hamilton. ${ }^{3}$

As the subsequent record shows, the Davis administration had good reason to fear any state election. In 1871 all four congressional seats were captured by Democrats, who piled up a statewide majority of 24,279. In the following year Texas was one of the six southern and border states which voted for Horace Greeley, the Liberal RepublicanDemocratic presidential nominee. In 1873 the Radicals lost nearly every office in the state, including the governorship. ${ }^{4}$ By 1876 the Democrats felt strong enough to write a new constitution which made no mention of the illegality of secession, the supremacy of Federal laws, or the right of all persons to vote regardless of race. 5

\footnotetext{
${ }^{3}$ Ibid., 39-40.

${ }^{4}$ Ibid. , 102-19.
}

${ }^{5}$ Bancroft, History of the North Mexican States and Texas, II, 515-16. Modern historians maintain that there was little difference between the Bill of Rights in the Texas constitutions of 1845, 1866, 1869, and 1876. See J. E. Ericson, "Origin of the Texas Bill of Rights," Southwestern Historical guarterly, LXII (1958-59), 466 and Edgar P. Snead, "A Historiography of Reconstruction Texas: Some Myths and Some Problems," ibid., LXXII (1968-69), 441. But the very fact that Texans desired to write a new constitution in 1876 shows a change in spirit from the 1869 document. This change is evident in the increased proscription suffered by Negroes after Reconstruction. See, e.g., Linn, Reminiscences of Fifty Years in Texas, 357; B. B. Lightfoot, "From Frontier to Farmland: Highlights of the History of Comanche County," West Texas Historical Association, Year Book, XXXII (1956), 36, and his "The Negro Exodus from Comanche County," Southwestern Historical Quarterly, LVI (1952-53), 412-13. 
Besides postponing elections, the Davis regime utilized the Texas State Police to ensure its control of state government. Established in 1870, the state Police had the authority to make searches and arrests without warrants and exercised a statewide jurisdiction in criminal matters. The governor appointed all of the members who were responsible to him alone. ${ }^{6}$ Early state historians condemn the state Police as one of the greatest evils of Reconstruction, ${ }^{7}$ while more modern scholars defend it and demonstrate its great contribution in assuring law and order. ${ }^{8}$ Both of these criticisms, however, ignore the obvious significance of the state Police. It was not necessarily a police force designed to preserve law and order or to replace the defunct Texas Rangers, although it may have performed creditably in that task. Its basic purpose was to replace the Army and handle not only the soldiers' police duties, but also their political functions, such as policing the polls and protecting Republican voters and loyal men in general. 9

Because of the similarity in functions between the state Police

6William T. Field, Jr., "The Texas state Police, 1870-1873," Texas Military History, V (1965), 131 .

7 Webb, Texas Rangers, 221; Nunn, Texas Under the Carpetbaggers, 43; Brown, History of Texas, II, 454. A $\overline{\text { good }}$ survey is in Ann Patton Baenziger, "The Texas State Police During Reconstruction: A Reexamination," Southwestern Historical Quarterly, LXXII (1968-69), 470 .

8Baenziger, "Texas State Police," 472-73, 476-77, 490-91;

Field, "Texas State Police," 136-38.

9 Ramsde11, Reconstruction in Texas, 301-303; McKay, "Texas Under the Regime of E. J. Davis," 120-21; Otis Singletary, "The Texas Militia During Reconstruction," Southwestern Historical Quarterly, LX (195657), 23-35. See also, Journal of the Reconstruction Convention . . . 1868, I, 111-12; Jacob Weber to A. M. Bryant, May 31, 1868, Governor's papers (Pease). 
and the Army, there was some confusion even among contemporaries as to when Military Reconstruction ended and the Army turned over the policing of elections to the state Police and state Militia. ${ }^{10}$ Numerous accounts assert that during Reconstruction voters had to pass between two lines of black soldiers armed with rifles and bayonets. These same authorities erroneously refer to these blue-uniformed men as Federal soldiers. Because the Army did not use Negro troops in the interior, they were more likely members of the state police and state Militia raised by the Davis regime to watch elections in the early 1870 's after the Army no longer interfered in civil affairs. ${ }^{11}$

The enrollment of Negroes in the State Police, State Militia, and the election of some Negroes to state offices caused the Democrats and some historians to claim that Texas suffered from "Negro rule."12 These assertions are highly inaccurate. Although the Army encouraged Negroes to register and vote, ${ }^{13}$ black political influence was kept at an absolute minimum by the racist attitudes of scalawags who composed a majority of the Davis government. They refused to elect a Negro as

\footnotetext{
10 Rogers, Lusty Texans of Dallas, 100; Moore, "Anderson County

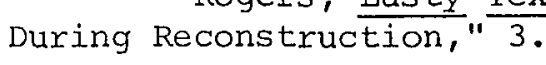

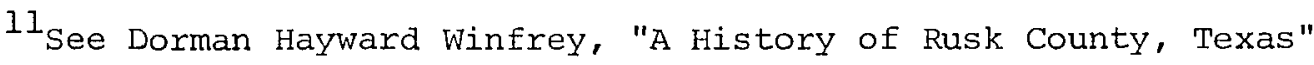
(Unpublished M.A. thesis, University of Texas, Austin, 1951), 84; Memorial and Biographical History of Navarro, Henderson, Anderson, Limestone, Freestone, and Leon Counties, 206, 418; Pauline Yelderman, "The Jaybira Democratic Association of Fort Bend County" (Unpublished M.A. thesis, University of Texas, Austin, 1938), 11-12; Atkinson, "History of Bell County," 131.

12 Studies that state or imply that Texas suffered from Negro rule include: Budd, "The Negro in Politics in Texas"; McKay, "Texas Under the Regime of E. J. Davis"; Bancroft, A History of the North Mexican States and Texas; Ramsdell, Reconstruction in Texas; Nunn, Texas Under the Carpetbaggers.

$$
{ }^{13} \text { Circ. 14, May 1, 1867, Printed Orders, District of Texas. }
$$


U. S. Senator, to nominate or appoint blacks to any important state office, to help raise bond money for those black candidates who needed it, or to protect their political and civil rights. ${ }^{14}$ It was not for moral reasons that most Texas Republicans supported the black vote. It was almost purely political in nature; the Negro vote offered them power. ${ }^{15}$ without the freedmen's support, the Republicans felt they had no chance to win an election.

In Texas, however, along with Georgia and Virginia, the Negro was in an obvious minority position even when his votes were combined with the scalawags'. ${ }^{16}$ More was needed to assure the Republicans of a

${ }^{14} \mathrm{~J}$. Mason Brewer, Negro Legislators of Texas and Their Descendants: A History of the Negro in Texas Politics From Reconstruction to Disfranchisement (Dali $\overline{1 a s,} 1 \overline{935} \overline{, 18}-\overline{19,28-30}, \overline{39}, \overline{47-51,55-56}$, 58-59. For a list of Negro legislators and members of the state conventions of 1869 and 1876, see ibid., 125-28. The Negro vote probably had more impact on county and city levels than state government. See Yelderman, "The Jaybird Democratic Association," 16-17; Frank MacD. Spindler, "Concerning Hempstead and Waller County," Southwestern Historical Quarterly, LIX (1955-56), 455-58; Works Progress Administration, Houston, 85; Lawrence Ward St. Clair, "History of Robertson County" (Unpublished M.A. thesis, University of Texas, Austin, 1931), 147; Tausch, "Southern Sentiment Among the Texas Germans," 80. Other historians, however, are not certain the Negro had much influence on local politics. See Winfrey, "History of Rusk County," 85-86, who finds that local scalawags helped prevent the Negro vote from becoming "oppressive." White, "A History of . . . Waller County," 114, 120, admits the Negro vote was a "problem," but that no effort was made to keep blacks from the polls. Instead, the white factions clashed with each other over who should control the Negro votes. Rogers, Lusty Texans of Dallas, 100 , finds that Dallas suffered little from Negro rule although black voters outnumbered whites.

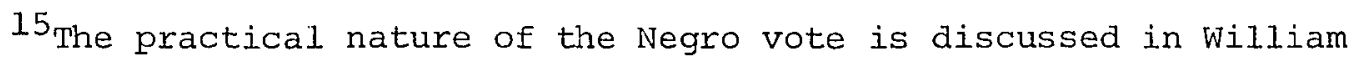
Gillette, The Right to Vote: Politics and the Passage of the Fifteenth Amendment (Baltimore, 1965).

$16_{A}$ good argument could be made that the Democrats threw the 1869 election by refusing to vote for Hamilton because they feared that a Davis victory was the only way to convince Congress to readmit Texas to statehood. Approximately 22,000 registered voters did not show up at the polls. See GO 73, April 16, 1870, Printed Orders, Fifth Military District; Texas Almanac (1870), 194, for the registration and 
majority at the polls. The question of how to achieve the additional votes necessary for a majority split the Republicans into two factions. A. J. Hamilton, Pease, John L. Haynes, and others decided to be political realists and broaden their support. The only other source of votes left to them was the "thinking element" of the old Democratic party. To attract these educated, respectable men to their standard, Hamilton and Pease refused to allow the convention to disfranchise former Confederates. For the same reason, they opposed an ab initio declaration and division of the state.

Their opponents within the party, Davis, M. C. Hamilton, and others, refused to make any compromise with the secessionist element. Like their counterparts in Congress, the Texas Radicals were determined to remake American society according to the dictates of moral theory. These Radicals were men of principle. Dogmatic and doctrinaire, they believed that they alone possessed truth and justice, and they were willing to go to any ends to accomplish their goal. In this respect, the Radicals were not typical American politicians. They were revolutionaries, not compromisers. ${ }^{17}$ Because these idealogues

voting figures. The assertion by Nunn, Texas Under the Carpetbaggers, 16, that the Democratic candidate kept Hamilton from winning seems to be in error because he carried less than 400 votes. The interpolations of the Negro vote used by Budd, "The Negro in Politics in Texas," 6-7, 15-16, 46, 52, are based on the 1860 census and are thus suspect. There were many more Negroes in Texas between 1865 and 1869 than in 1860. To use the 1860 census only provides a false picture.

17 For a good analysis of Radical Republican politicians, see T. Harry Williams, "Lincoln and the Radicals: An Essay in Civil War History and Historiography," in Grady McWhiney (ed.), Grant, Lee, Lincolin and the Radicals: Essays on Civil War Leadership (New York, 1966), 93, 99, 100-102, 104, 106. For a less developed, yet similar, description of the Radicals, see Thomas Nelson Page, "The Southern People During Reconstruction," Atlantic Monthly, LXXXVII (1901), 296, 298 . 
refused to compromise to attain an electoral majority, they had to use othex means to come into power. They turned to the Army and, in so doing, they removed themselves from the democratic process. The Radicals resorted to tyranny--the tyranny of the right, the moral, and the good. The doom of the Republican party was sealed when the Radicals refused to play politics within the system.

Because the military is a disciplined institution dedicated to obeying orders, the Army easily adapted itself to its Reconstruction role. ${ }^{18}$ Therefore, the men of importance are the commanders of the Fifth Military District and the District of Texas who determined the policy of the soldiers under their command. ${ }^{19}$ Not all of these men were necessarily allies of the Republicans. The greatest obstacle to party goals was Hancock's General orders No. 40. While this order appears on the surface to be a guarantee of basic civil liberties, Hancock's reliance on majority rule was actually the easiest way to delay Republican success in the Fifth Military District.

Unlike Hancock, Canby did not openly support either party. He exercised good judgment in dealing with former Confederates. He never tried to overawe them with a show of excessive strength, yet he also adamantly protected the rights of Loyalists and Negroes. His action in preserving the convention records and the Reconstruction constitution while he pacified the state and reorganized local government to enable elections was admirable. His efficiency and drive, however, tended to favor the Conservatives and discriminate against the Radicals who

\footnotetext{
${ }^{18}$ Sefton, United States A.rmy and Reconstruction, ix. ${ }^{19}$ Ibid. , 25, 28, 92-93, 214, 217, 253.
} 
needed time to build up their party. Sheridan occupied the middle ground because, as much as he was in agreement with the goals of congressional Reconstruction, he would not allow Griffin to make wholesale removals until late August 1867. In effect, Little Phil was nearly as much of an "impediment to reconstruction" as were Hancock and Canby. His acid personality, however, prevented Texans from comprehending this fact. The interim commanders of the Fifth Military District, Mower and Buchanan, really did not exist as far as Texas affairs were concerned. Mower gave Reynolds a free hand throughout his term. By the time Buchanan attempted to assert his influence, Louisiana had been readmitted to the Union and Texas removed from his supervision. The key to understanding Texas Reconstruction is found in the roles that Griffin and Reynolds played. Each of them was willing to use the Army to build the Republican party. Griffin began the process in late August 1867 by using the powers of removal and appointment recently granted to local commanders by the Third Reconstruction Act. His tragic death, however, prevented him from carrying his task to completion. Griffin seemed to offer the Army's assistance unconditionally, but his successor, Reynolds, demanded favors in return for his aid. The Republicans, through Governor Pease, recognized the military's supremacy over civil government and, in exchange, Reynolds removed the incumbent Democrats and replaced them with Republican appointees.

Reynolds' removal of Democrats in 1867, Radicals in the following spring, and the Moderate Republicans in the autumn of 1868, led to much confusion over who legally held various state and local 
offices. ${ }^{20}$ Even headquarters at Austin could not keep up with the constant changes in personnel made by Reynolds. The general's bewildered adjutant once wrote the post commander at Indianola asking who had appointed a man named Hayes Yarrington as hide inspector, who had removed him, and who currently held the position. 21 The constant turnover of offices also resulted in a shortage of personnel. Many appointees refused to serve or could not take the oath ${ }^{22}$ and this forced Reynolds to appoint soldiers to some positions. 23

Because of the wide discretion allowed by the Reconstruction Acts, the personality of each commander largely determined the character of Military Reconstruction in his district. Although Reynolds possessed little administrative ability, ${ }^{24}$ he had a flair for political intrigue. "Radicals as a rule are more morose than otherwise," com-

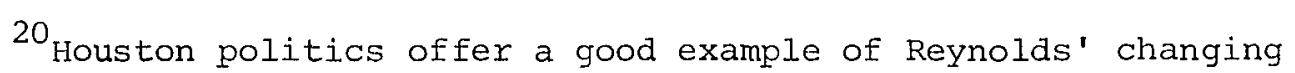
support. See Merseburger, "A Political History of Houston," 1-7, 9, $11-12,13,18,19,21-22,28-29,31,44-48,62,72-74,78,88,97$.

$21_{\text {AAAG }}$ to CO, Post of Indianola, June 8,1869 , Letters Sent, Fifth Military District records.

22 The sheriff's position was usually the most difficult to fill. See H. T. Grun to Pease, [August --, 1865], Pease papers; Buel to AAG, January 6, 1869, Carleton to AAG, March 14, 1869, Letters Received, Fifth Military District records; Secretary of Civil Affairs to CO, Post of Greenville, August 3, 1869, Assistant Secretary of Civil Affairs to CO, Post of Waco, September 2, 1869, Letters Sent, Civil Affairs, ibid.; B. F. Barkley to AAG, April 27, 1870, Letters Received, Civil Affairs, ibid. See also, so 1, August 10, so 4, August 13, so 5, August 14, so 7, August 17, so 10, August 20, so 12, August 22, 1868, Printed Orders, Fifth Military District.

23 Assistant Secretary of Civil Affairs to CO, Post of Jefferson, August 19, 1869, Letters Sent, Civil Affairs, Fifth Military District records; So 84, April 16, 1870, Printed Orders, Fifth Military District. See also, Sefton, United States Army and Reconstruction, 137-38, $140,142-43$.

24 Horace Porter to Grant, January 8, 1869, in Sefton, United States Army and Reconstruction, 190. 
mented one Democratic editor, "but the General is an exception. A more affable or oily man does not live." Reynolds had an uncanny ability to extract information from those bent on keeping secrets, or "a most powerful force pump," in the words of the same critic. "When applied to [a] man it leaves him with nothing to say in less than five minutes," he continued, "or, in other words, it leaves him without a secret in that time." 25

He alone was responsible for the Radical success in 1869, and every knowledgeable person in Texas knew it. ${ }^{26}$ Unlike most officers, Reynolds lacked the political aloofness that is part of the Army's tradition. 27 Even friendly newspapers that believed his administration was marked with "firmness, moderation, and justice" felt it was wrong for him to openly seek political rewards. Reynolds' ambition was too blatant, however, and it cost him the senate seat in 1870.28

Reynolds' role in Texas aptly demonstrates that despite the military and civil controls built into the American system of govern-

25 Brownsville Daily Ranchero, January 15, 1870. For more on Reynolds' character and flair for intrigue, see J. W. Vaughn, The Reynolds Campaign on Powder River (Norman, 1961), 25, 148-90.

${ }^{26}$ See, e.g.., San Antonio Herald, January 10, 1870. Most revealing of Reynolds' crucial role in determining who was elected is the request of an Indianola board of registrars for the general's advice on the 1869 election. Ten doubtful ballots were enclosed in the message. The board said that if they were counted, a Republican sheriff would be elected, if not, a Democrat would win. It is not enough to say that the board was trying to avoid its responsibility; the important factor was Reynolds' willingness to assume the responsibility. See Board of Registrars to AAG, December 4, 1869, Letters Received, Civil Affairs, Fifth Military District records.

27 For the army officers' traditional aloofness from politics, see Sefton, United States Army and Reconstruction, 253.

${ }^{28}$ Austin Weekly Republican, September 15, 1869. 
ment, the sweeping powers of military rule can easily lead to arbjtrary righteousness and wrongdoing. As one Civil War general belatedly recognized, military yovernment was "a terrible machine, capital, like fire when under good control, . . but awful as a conflagration when it escapes beyond the bounds of truth and right. . . " He lamented, "How few men there are who are really fit to be entrusted with such power." 29

The inability of Reynolds to control the limits of his political interference is even more markedly revealed when his administration is compared to that of Major General John Schofield in Virginia. Schofield realized that the congressional acts were a terrible oppression, yet he ruled Virginia with an iron hand and showed favor to neither black nor white. He divided the state into fifty-five districts and placed an officer charged with civil affairs in each area. Schofield refused to make many removals and allowed local citizens to assist in choosing qualified men. He disliked extremists and preferred any moderate person, Republican or Democrat, who could take the oath. registration boards had one military representative, and troops patrolled all election sites to insure a fair count. Schofield threatened to use military courts whenever necessary but he rarely resorted to them. His impartiality in Virginia politics was praised throughout the state. 30

${ }^{29}$ See Frank L. Byrne, "'A Terrible Machine': General Neal Dow's Military Government on the Gulf Coast," Civil War History, XII (1966), 5-22, especially 22 .

${ }^{30}$ James L. McDonough, "John Schofield As Military Director of Reconstruction in Virginia," ibid., XV (1969), 237-56. See also, Sefton, United States Army and Reconstruction, 120-21. 
In general, Reynolds' political manipulation notwithstanding, the Army conducted itself well in Texas. It handled the race question with relative conservatism, defended the frontier, suppressed outlaws, held reasonably fair trials, curtailed the spread of contagious disease, and administered even minor governmental affairs on the county and municipal levels. ${ }^{31}$ Yet the Texas whites hated the Army and its "glorious system of reconstruction," as one planter sarcastically phrased it. "I look for serious trouble all over the South," he continued, "when the incendiary scoundrels now overrunning the country - . learn of the wiping out of all civil law \& the placing [of] us under Military Govt." A Houston woman wrote a friend to complain about "the blue-coated dogs of despotism in \& around our town. There seems to be no end to these \& their congeries--the free niggers. Devil take them all say I." 32

At times Texans expressed their hatred of military rule in violent ways. Some historians have blamed Reconstruction violence on the small numbers of soldiers stationed in the South, saying this showed how weak military control really was. ${ }^{33}$ other writers maintain

${ }^{31}$ Sefton, United States Army and Reconstruction, 27-31, 37, $42-43,127,128, \overline{137,14} 4 \overline{7-48,} \overline{65}, \overline{167-68,185,193,229}, 233,253-54$, 257.

${ }^{32}$ Affleck to 0. Judd and Co., January 26, 1868, Affleck papers; Jeannie Chew Young to Louisa Wharton, January 16, 1866, Wharton papers.

33 John Hope Franklin, Reconstruction: After the Civil War (Chicago, 1961), 35-36, 119-2); Robert $w$. Shook, "Military Activities in Victoria, 1865-1866," Texana, III (1965), 351-52, and his "Federal Military Activity in Texas, 1865-1870," Texas Military History, VI (1967), 44-45. Shook's assertion in the earlier article "that military occupation in both extent and ramification has been highly exaggerated" ignores the ensuing involvement of the Army in local government and Reynolds' meddling in state politics. His article in Texas Military History is unfortunately weak on research with many factual 
that the Army's power, influence, and activity cannot be measured in numbers alone because the blue uniform had a great psychological effect on southern whites. Rarely would whites attack a Federal troop contingent, these historians maintain, because they feared the severe repercussions that would follow. ${ }^{34}$

It is true the Army had a great deal of influence in Texas regardless of numbers; this is demonstrated by Reynolds' political power. Each political faction anxiously sought the Army's approval and support of its program. The blue uniform, however, had a dubious psychological effect in other situations of potential violence. ${ }^{35}$ All too often Texans (citizens, not guerrillas) were more than willing to challenge the Army's authority in the state. "Blue was as enraging to secesh eyes - . as red is to the eyes of a turkey gobbler," said one Unionist. 36 Loyal men commonly reported that "occasional visits

errors, although he does seem to admit that "military officers were thrust, perhaps prematureiy" into state politics. A similar debate exists among historians of Florida Reconstruction. Merlin E. Cox, "Military Reconstruction in Florida," Florida Historical Quarterly, XLVI (1967-68), 219-33, illustrates the moderate course pursued by the Army, while Ralph L. Peek, "Military Reconstruction and the Growth of the Anti-Negro Sentiment in Florida, 1867," ibid., XLVII (1968-69), 380-400, asserts that in spite of its moderate action, the Army was instrumental in helping to separate the races and destroy the political viability of the state Republican party.

${ }^{34}$ Sefton, United States Army and Reconstruction, vii-viii, 87, 183, 225, 226; William A. Dunning, Reconstruction, Political and Economic, 1865-1877 (New York, 1907), 109 .

${ }^{35}$ Occasionally the blue uniform did prevent violence. See Brig. Gen. James A. Shaw to AAG, April 16, May 1, 1866, House Executive Documents, 40th Cong., 2nd Sess., No. 57, 96-97; Jacob weber to A. M. Bryant, May 31, 1868, D. Campbell to Pease, August 25, 1868, Governor's papers (Pease); Crocket, Two Centuries in East Texas, 348-49.

${ }^{36}$ North, Five Years in Texas, 187. 
from soldiers only exasperates lawlessness." In typical incidents, armed townspeople besieged Federal cavalrymen for days in the Tyler county courthouse until a relief column could arrive, while an infantry company making a routine arrest in Navasota was prevented from passing down the town's main street by an armed mob. ${ }^{37}$ Undoubtedly much of this dislike for the Army was racial in nature. Texans knew that only the military's presence allowed the scalawags and Negroes to take part in governing the state. The Army, however, provoked many incidents. Texans could always point an accusing finger at the seventeenth Infantry's drunken, riotous conduct in the southeastern part of the state, particularly the burning of Brenham.

When all of the positive and negative aspects of military rule were combined, Texans found they disliked it for one basic reason-it was a denial of what they believed to be the basic rights of selfgovernment. The very thoroughness of military government, the concern with sanitary regulations, municipal laws, newspaper censorship, tax collection, property seizures, and court cases, also created the impression of a very real tyranny. ${ }^{38}$ The South, particularly the Southwest, considered itself a bastion of democracy. ${ }^{39}$ Texas had a

${ }^{37}$ Hamilton to Sheridan, Uanuary 17, 1866, Sheridan to Grant, January 25, 1866, House Executive Documents, 40th Cong., 2nd Sess., No. 57, 19-20, 34-35; AAAG to CO, Post of Jefferson, December 25, 1868, Letters Sent, Fifth Military District records; D. W. Scroggins to AAG, July 12, 1869, Letters Sent, Civil Affairs, ibid.

38 William A。 Dunning, Essays in Civil War and Reconstruction (New York, 1904), 146, 156-57, 174-75; Dunning, Reconstruction, 109-10.

39 On Democracy in the South, see Ralph A. Wooster, The People in Power: Courthouse and Stateliouse in the Lower South, 1850-1860 (Knoxville, 1969), 24-26, 91, 105-107, 113-14, 116-17. See also, Fletcher M. Green, "Democracy in the old South," Journal of Southern History, XII (1946), 3-23. Particularly significant for Reconstruction was 
long history of fighting real or supposed tyrannies. Her own war for independence began in part over how much power the Mexican government would be able to assert in its northern province of Texas. The states rights Democrats controlled Texas politics during the ante-bellum period. When the Civil War came, a Texan, Louis T. Wigfall, helped lead the opposition to Jefferson Davis' centralization of Confederate power in Richmond, while Governors Lubbock and Murrah guarded the state from transgressions against her sovereign rights by Kirby Smith's military government. 40

The only compromise Texans were willing to make with their pre-war principles in 1865 was to become states rights nationalists like their northern Democratic brethren who had opposed Lincoln's "unconstitutional" war measures. This position was the one Governor Throckmorton adopted ${ }^{41}$ before sheridan removed him from office as an "impediment to reconstruction." Yankee military control was merely one more form of tyranny to overcome before Texans could enjoy their full rights of participation in the democratic process. "Under the head of Military Necessity various and sundry things have been done," said the Brownsville Daily Ranchero. "Under this plea . . a nation has well nigh parted with her liberties. Under this claim, which is

that the power of the governor in the lower South, including Texas, was subordinated to the will of the state legislature. Hence, Texas saw the increased power of the executive, as represented by the Army commander, as an imbalance in government.

${ }^{40}$ In addition to Chapter I above, for the Texans' resentment of Confederate military government, see Walker, "San Antonio During the rivil War," 53-59. II, 488 .

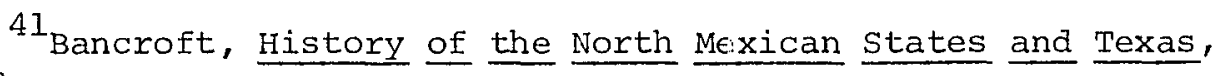


superior to law, equity, [and] justice, . . very strange things have been done. What has not been done," challenged the newspaper, "under a military necessity plea?" 42

The United States was faced with a horrible quandary in Texas. It had to subject the democratic process of self-government to military regulation and remove equal rights from the majority to protect a deserving minority. The alternative was to allow the whites to rule as before the war and reserve second-class citizenship for the freedmen. According to the first Texas state constitution (1845), "AlI political power is inherent in the people, and all free governments are founded on their authority and instituted for their benefit." Most white Texans believed that the role the Army played during Reconstruction was a denial of this basic truth.

42

Brownsville Daily Ranchero, March 6, 1868; Wood, Reminiscences of Reconstruction in Texas, 3 . One of the myths of Reconstruction is that Texans would have preferred military rule to readmission in 1870. See Brownsville Daily Ranchero, september 13, 1867, January 22, 1870; Texas News (Bonham), February 27, 1869. This was merely a political maneuver on the part of conservatives to keep Davis out of power. The same sentiments had been voiced by Republicans against the Throckmorton government in 1866. See Judge John Dix to Pease, July 16, 1866, Pease papers. 


\section{BIBLIOGRAPHY}

\section{A. Manuscript Collections}

1. Military Documents

Letters Received by the Office of the Adjutant General (Main Series), 1861-1870. File 57M1868, Microcopy 619, Roll 634.

Records of the Adjutant General. Record Group 94. National Archives. Records of the Fifth Military District and the District of Texas. Record Group 303. National Archives.

Records of the Texas Freedmen's Bureau. Record Group 105. National Archives.

\section{Texas state Papers}

Election Register, 1866-1870. Archives. Texas State Library. Executive Correspondence, 1865-1870. Archives. Texas State Library. Secretary of State's Papers. Letter Books and Proclamations of the Governors. Archives. Texas State Library.

Texas Adjutant General's Office. Transcript of Records, 1838-1869. Archives. University of Texas Library.

\section{Personal Papers}

Thomas Affleck Papers. Department of Archives and Manuscripts. Louisiana State University Library.

Amelia Barr Letters. Archives. University of Texas Library.

James H. Bell Papers. Archives. University of Texas Library.

R. W. Black Papers. Archives. University of Texas Library.

Frank Brown Papers. Archives. University of Texas Library.

J. R. Cressinger Civil War Letters. Archives. University of Texas Library. 
B. H. Epperson Papers. Archives. University of Texas Library.

R. Niles Graham-E. M. Pease Collection. Archives. Austin Public Library.

U. S. Grant Papers. Manuscripts Division. Library of Congress.

Samuel Peter Heintzelman Papers. Manuscripts Division. Library of Congress.

Andrew Jackson Hamilton Papers. Archives. University of Texas Library .

Charles Adelbert Herff Reminiscences. Archives. University of Texas Library .

Andrew Johnson Papers. Manuscripts Division. Library of Congress.

W. W. Mills Papers. Archives. University of Texas Library.

Charles H. Moore Reminiscences. Archives. University of Texas

Library.

James Pearson Newcomb, Sr. Papers. Archives. University of Texas Library.

John Reid Papers. Department of Archives and Manuscripts. Louisiana State University Library.

Philip H. Sheridan Papers. Manuscripts Division. Library of Congress.

James Webb Throckmorton Papers. Archives. University of Texas Library.

R. H. Watlington Reminiscences. Archives. University of Texas Library.

Edward Clifton Wharton Papers. Department of Archives and Manuscripts. Louisiana State University Library.

\section{B. Printed Official Materials}

\section{Congressional Documents}

39 th Cong., lst Sess. House Executive Documents, No. 1 (Report of the Secretary of War, 1865).

House Executive Documents, No. 70 (Freedmen's Bureau). House Reports, No. 30 (Report of the Joint Committee on Reconstruction). 
Senate Executive Documents, No. 2 (Condition of the South). Senate Executive Documents, No. 43 (Report of Benjamin C. Truman).

39th Cong., 2nd Sess.

House Executive Documents, No. 1 (Report of the Secretary of War, 1866).

House Reports, No. 61 (Condition of Affairs in Texas).

40th Cong., lst Sess.

House Executive Documents, No. 20 (Letter from the Secretary of War).

House Executive Documents, No. 30 (Correspondence with Ministers to Mexico).

House Executive Documents, No. 34 (Interpretation of the Reconstruction Acts).

40th Cong., 2nd Sess.

House Executive Documents, No. 1 (Report of the Secretary of War ad interim and the General, U.S.A.).

House Executive Documents, No. 25 (Mexican Affairs--Maximilian). House Executive Documents, No. 57 (Removal of Hon. E. M. Stanton and others).

House Executive Documents, No. 342 (General Orders--Reconstruction).

40 th Cong., 3rd Sess.

House Executive Documents, No. 1 (Report of the Secretary of War, 1868).

Ilvuse Exccutive Documents, No. 97 (Constitutional Convention of Texas).

4lst Cong., 2nd sess.

House Executive Documents, No. 1 (Report of the Secretary of War, 1869).

House Executive Documents, No. 59 (Expenses of Texas Election). House Executive Documents, No. 60 (Oath in Texas).

House Executive Documents, No. 211 (Officers on Duty in the Southern States). House Executive Documents, No. 228 (Sites of Military Posts in Texas).

House Executive Documents, No. 265 (Elections in the Second District of Texas).

4lst Cong., 3rd Sess.

House Executive Documients, No. 1 (Report of the Secretary of War, 1870).

House Executive Documents, No. 145 (Burning of Brenham, Texas, $1866)$. 
42nd Cong., 2nd Sess.

House Executive Documents, No. 22 (Affairs in the Late Insurrectionary states).

House Executive Documents, No. 216 (Political Complexion of Affaixs on the Texas Frontier).

42nd Cong., 3rd sess.

House Executive Documents, No. 39 (Depredations on the Frontier of Texas).

43rd Cong., lst Sess.

House Executive Documents, No. 222 (Protaction of the Texas Frontier).

\section{Other Printed Documents}

Cullum, George w. Biographical Register of the Officers and Graduates of the U. S. Military Academy at West Point, New York, From Its Establishment March 16, 1802 to the Army Reorganization of 1866-1867. 2 vols. New York, 1868 .

Gamme1, Hans Peter Nielsen (comp.). The Laws of Texas, 1822-1897. 10 vols. Austin, 1898.

Heitman, Francis B. Historical Register and Dictionary of the United States Army, From Its Organization, September 29, 1789 to March 2 , 1903. 2 vols. Washington, 1903 .

Kennedy, Joseph C. G. (comp.). The Population of the United States in 1860; Compiled From the Original Returns of the Eighth Census. . Washington, 1864 .

Official Records of the Union and Confederate Navies in the War of Rebellion. 26 vols. Washington, 1894- $\overline{1922 .}$

Richardson, James D. (comp.). A Compilation of the Messages and Papers of the Presidents, 1789-1897. 10 vols. Washington, 1897.

Texas. Journal of the Reconstruction Convention Which Met at Austin, Texas, June 1 , A.D., 1868. 2 vols. Austin, 1870 .

- Journal af the State Convention Assembled at Austin, February 7, 1866. Austin, 1866.

Walker, Francis A. (comp.). The Statistics of the population of the United States. . . Washington, 1872.

War of the Rebellion: A Compilation of the Official Records of the Union and Confederate Armies. 128 vols. Washington, 1880-1901. 
C. Newspapers, 1865-1870

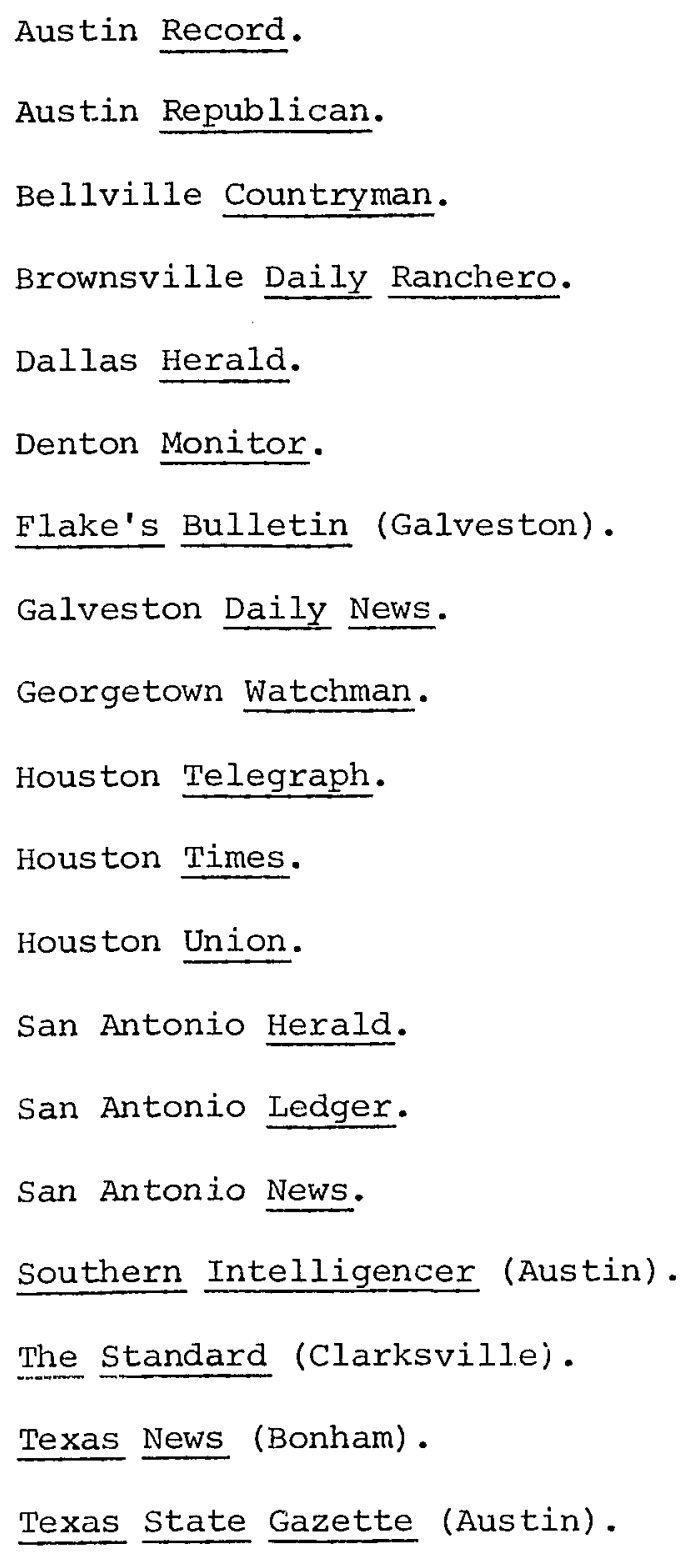


Barkley, Mary Starr. History of Travis County and Austin, 1839-1899. Waco, 1964.

Bartholomew, Ed. Cullen Baker: Premier Texas Gunfighter. Houston, 1954.

Bemis, Samuel Flagg. The American Secretaries of State and Their Diplomacy. 10 vols. New York, 1927-1929.

Bentley, George R. A History of the Freedmen's Bureau. Philadelphia, 1955.

Brewer, J. Mason. Negro Legislators of Texas and Their Descendants: A History of the Negro in Texas Politics From Reconstruction to Disfranchisement. Dallas, 1935.

Brown, John Henry. History of Texas From 1685 to 1892. 2 vols. St. Louis, $18 \overline{93}$.

Burke, Ulick Ralph. A Iife of Benito Juarez, Constitutional President of Mexico. London, $1 \overline{894}$.

Califf, Joseph Mark. Records of the Services of the Seventh Regiment U.S.C.T. From september 1863 to November $1866 . \cdots$ Providence, $18 \overline{78}$.

Callcott, Wilfred Hardy. Liberalism in Mexico, 1857-1929. Palo Alto, Calif., 1931.

Carpenter, John A. Sword and Olive Branch: Oliver Otis Howard. Pittsburgh, 1964 .

Carter, W. A. History of Fannin County, Texas, History, Statistics, and Biographies. Bonham, Texas, 1885.

Carter, W. H. From Yorktown to Santiago With the Sixth U. S. Cavalry. Baltimore, 1900 .

Casdorph, Paul. A History of the Republican Party in Texas, 1865-1965. Austin, $19 \overline{6} 5$.

Case, Lynn M. (ed.). French Opinion on the United States and Mexico, 1860-1867: Extracts From the Reports of the Procureurs Generaux. New York, $\overline{1936}$.

The Civil Record of Major General Winfield S. Hancock, During His Administration in Louisiana and Texas. N.p., 1871 .

Clark, Charles T. Opdyke Tigers, 125th Ohio Volunteer Infantry, A History of the Regiment and of the Campaigns and Battles of the Army of the Cumberland. Columbus, 1895. 
Clendenen, Clarence C. Blood on the Border: The United States Army and the Mexican Irregulars. New York, 1969 .

Cogley, Thomas Sydenham. History of the Seventh Indiana Cavalry Volunteers . . . Laporte, Indiana, 1876 .

Corti, Egon Caesar Count. Maximilian and Charlotte of Mexico. Trans. by Catherine Alison Phillips. 2 vols. New York, 1928.

Crocket, George Louis. Two Centuries in East Texas: A History of San Augustine County and the Surrounding Territory, From 1685 to the Present Time. Dalias, 1932 .

Crouch, Carrie J. Young County: History and Biography. Dallas, 1937.

Custer, Elizabeth B. Tenting on the Plains, or General Custer in Kansas and Texas. New York, 1887 .

Dabbs, Jack Autrey. The French Army in Mexico, 1861-1867: A Study in Military Government. The Hague, 1963.

Davis, Susan Lawrence. Authentic History: Ku Klux Klan, 1865-1877. New York, 1924.

Dawson, Daniel. The Mexican Adventure. London, 1935.

Denison, C. W. Illustrated Life, Campaigns, and Public Services of Philip $\mathrm{H}$. Sheridan. Philadelphia, 1865 .

Dobie, J. Frank. A Vaquero of the Brush Country. Boston, 1949.

Du Bois, W. E. B. Black Reconstruction: An Essay Toward a History of the Part Which Black Folk Played in the Attempt to Reconstruct Democracy, 1860-1888. New York, 1935.

Dunning, William Archibald. Essays on the Civil War and Reconstruction. New York, 1904.

- Reconstruction, Political and Economic, 1865-1877. New York, 1907.

Dyer, Frederick H. A Compendium of the War of the Rebellion. 3 vols. New York, $195 \overline{9}$.

Elliott, Claude. Leathercoat: The Life History of a Texas Patriot. San Antonio, 1938.

Fletcher, Samuel H., and D. H. Fletcher. $\underline{\text { A History }}$ of Company $\underline{A}$, 2nd Cavalry. Chicago, 1912.

Ford, John Salmon. Rip Ford's Texas. Ed. by Stephen B. Oates. Austin, 1963. 
Forney, John w. Life and Military Careex of Winfield Scott Hancock . . , Also . - A Sketch of the Hon. William H. English. Rochester, New Yor , 1880.

Franklin, John Hope. Reconstruction: After the Civil War. Chicago, 1961 .

Franks, J. M. Seventy Years in Texas: Memories of the Pioneer Days, Indian Depredations, and the Northwest Cattle Trail. Gatesville, Texas, 1924.

Freed, Augustus Toplady. Hancock: The Life and Public Services of Winfield Scott Hancock. Chicago, 1880 .

Fritz, Henry E. The Movement for Indian Assimilation, 1860-1890. Philadelph $\overline{i a}, \overline{1963 .}$

Fulfer, Richard J. A History of the Trials and Hardships of the Twenty-fourth Indiana Volunteer Infantry. Indianapolis, 1913.

Goodrich, Frederick $O$. The Life and Public Services of Winfield Scott Hancock, Ma jor General, ‥S.A. Boston, 1880 .

Hancock, Mrs. A. R. Reminiscences of Winfield Scott Hancock by His Wife. New York, 1887.

Haskin, William Lawrence. The History of the First Regiment of Artillery From Its organization in 1821 to January 1 , 1876 . . Portland, Maine, 1879 .

Heyman, Max L., Jr. Prudent Soldier, A Biography of Major General E. R. S. Canby, 1817-1873. Glendale, Calif., 1959 .

A History of Texas: History of Milam, Williamson, Bastrop, Travis, Lee, and Burleson Counties. Chicago, 1893 .

Holbrook, William C. A Narrative of the Officers and Enlisted Men of the Seventh Regiment of Vermont Volunteers From 1862 - 1866 . New York, 1882 .

Horn, Stanley F. Invisible Empire: The Story of the Ku Klux Klan, 1866-1871. Boston, 1939 .

Howard, Oliver Otis. Autobiography. 2 vols. New York, 1908.

Huckabay, Ida Lasater. Ninety-four Years in Jack County. Austin, 1949.

Hughes, w. J. Rebellious Ranger: Rip Ford and the old Southwest. Norman, 1964 .

Huson, Hobart. Refugio: A Comprehensive History of Refugio County from Aboriginal Times to 1953. 2 vols. Woodsboro, Texas, 1953. 
Jordan, Terry G. German Seed in Texas Soil: Immigrant Farmers in Nineteenth Century Texas. Austin, 1966.

Kerwood, Asbury L. Annals of the Fifty-seventh Regiment Indiana Volunteers . . Dayton, Ohio, 1868.

Kimberly, Robert L. and Ephraim S. Holloway. The Forty-first Ohio Veteran Volunteer Infantry in the War of Rebellion, 1861-1865. Cleveland, 1897 .

Leathers, Frances Jane. Through the Years, A Historical sketch of Leon County, and the Town of Oakwood. Oakwood, Texas, $19 \frac{\text { O6. }}{1}$

Linn, John J. Reminiscences of Fifty Years in Texas, New York, 1883.

Lothrop, Charles Henry. A History of the First Regiment Iowa Cavalry . . Lyons, Iowa, 1890.

McConnell, H. H. Five Years A Cavalryman; or, Sketches of Regular Army Life on the Texas Frontier, Twenty odd Years Ago. Jacksboro, Texas, 1889 .

McFeeley, William S. Yankee Stepfather: General ㅇ․ ㅇ․ Howard and the Freedmen. New Haven, 1968.

Matloff, Maurice (ed.). American Military History. Washington, 1969.

Meinig, D. W. Imperial Texas: An Interpretive Essay in Cultural Geography. Austin, 1969.

Merington, Marguerite. The Custer Story: The Life and Intimate Letters of General George $A$. Custer and His Wife Elizabeth. New York, 1950.

Miller, Edmund Thornton. A Financial History of Texas. Austin, 1916.

Mills, W. S. History of Van Zandt County. N.p., 1950.

Mills, William W. El Paso, A Glance at Its Men and Contests for the Last Few Years . . Austin, 1871.

Monaghan, Jay. Custer: The Life of General George Armstrong Custer. Boston, 1959.

Nance, Joseph M. Early History of Bryan and the Surrounding Area. College Station, Texas, 1962 .

Neville, A. W. The History of Lamar County, Texas. Paris, Texas, 1937.

Newton, Alexander Heritage. Out of the Briars, An Autobiography and Sketch of the Twenty-ninth Regiment of Connecticut Volunteers. Philadelphia, 1910 . 
Nichols, James L. The Confederate Quartermaster in the Trans-Mississippi. Austin, 1964 .

North, Thomas. Five Years in Texas; or, What You Did Not Hear During the War From January 1861 to January 1866. Cincinnati, 1871.

Norton, Oliver Willcox. Army Letters, 1861-1865 . . Chicago, 1903.

Nunn, W. C. Escape from Reconstruction. Fort Worth, 1956.

- Texas Under the Carpetbaggers. Austin, 1962.

O'Connor, Richard. Sheridan, the Inevitable. Indianapolis, 1953.

Penniger, Robert. Fest-ausgabe zum 50-jaehregen Jubilaeum der Gruendung der stadt Friedrichsburg. Fredericksburg, Texas, 1896.

Perkins, Dexter. The Monroe Doctrine, 1826-1867. Baltimore, 1933.

Pierce, Paul Skeels. The Freedmen's Bureau: A Chapter in the History of Reconstruction. Iowa City, 1904 .

Priest, Loring Benson. Uncle Sam's Stepchildren: The Reformation of United States Indian Policy, 1865-1887. New Brunswick, 1942.

Proceedings of the State Assembly of the State of New York on the Life and Services of General Philip H. Sheridan, Held at the Capitol, April 9, 1889 . Albany, 1890.

Procter, Ben H. Not Without Honor: The Life of John $\underline{\text { H. Reagan. }}$ Austin, 1962 .

Prucha, Francis Paul. A Guide to the Military Posts of the United States, 1789-1895. Madison, Wis., 1964.

Ramsde11, Charles W. Reconstruction in Texas. New York, 1910.

Reagan, John. Memoirs, With Special Reference to Secession and the Civil Wax. New York, 1906 .

Richardson, Rupert N., et al. Frontier Forts of Texas. Waco, 1966.

Richardson, Rupert N. The Frontier of Northwest Texas, 1846 to 1876: The Advance and Defense by the pioneer Settlers of the Cross Timbers and Prairies. Glendale, Calif., 1963.

Rippy, J. Fred. The United States and Mexico. New York, 1931.

Rister, Carl Coke. Border Command: General Phil Sheridan in the West. Norman, 1944. 
Rister, Carl Coke. The Southwestern Frontier, 1865-1881: A History of the Coming of the Settler. . - and the Disappearance of the Frontier. Cleveland, 1928.

Rodesbough, Theodore F. and William L. Haskin (eds.). The Army of the United States. New York, 1896.

Rogers, John William. The Lusty Texans of Dallas. New York, 1951.

Rusl hore, Elsie Mitchell. The Indian Policy During Grant's Administrations. Jamaica, New York, 1914.

Seftion, James E. The United States Army and Reconstruction, 1865-1877. Baton Rouge, 1967.

Sheridan, Philip H. Personal Memoirs of Philip H. Sheridan. 2 vols. New York, 1888.

Sonnichsen, C. L. I'll Run Before I'll Die: The Story of the Great Feuds of Texas. New York, 1951 .

Speer, John W. A History of Blanco County. Austin, 1965.

Steward, T. G. The Colored Regulars in the U. S. Army - . From the Period of the Revolutionary War to 1899 . Philadelphia, 1904 .

Swint, Henry Lee. The Northern Teacher in the South, 1862-1870. Nashville, 1941.

Texas Almanac. $1865-1870$.

Thrall, Homer S. A Pictorial History of Texas, From the Earliest Visits of European Adventurers, to A.D. 1879. St. Louis, 1879.

Tucker, Glenn. Hancock, The Superb. Indianapolis, 1960.

The Union Army: A History of the Military Affairs in the Loyal States, Records of the Regiments of the Union Army . . 8 vols. Madison, Wis., 1908 .

Utley, Robert M. Frontiersmen in Blue: The United States Army and the Indian, 1848-1865. New York, 1967.

Van De Water, Frederic F. Glory Hunter: A Life of General Custer. Indianapolis, 1934.

Vaughn, J. W. The Reynolds Campaign on Powder River. Norman, 1961.

Walker, Francis A. General Hancock. New York, 1894.

Wallace, Exnest. Texas in Turmoil. Austin, 1965. 
Waller, John L. Colossal Hamilton of Texas: A Biography of Andrew Jackson Hamilton. El Paso, 1968.

Warner, Ezra J. Generals in Blue: Lives of the Union Commanders. Baton Rouge, 1964.

Webb, Walter Prescott. The Texas Rangers: A Century of Frontier Defense. Austin, 1965.

Wheeler, Kenneth $w$. To Wear a City's Crown: The Beginnings of Urban Growth in Texas, $1836-1865$. Cambridge, Mass., 1968.

White, Owen. Out of the Desert: The Historical Romance of El Paso. E1 Paso, 1923 .

Wilbarger, J. W. Indian Depredations jn Texas. Austin, 1935.

Wilson, Theodore B. The Black Codes of the South University, Alabama, 1965.

Winfrey, Dorman H. and James M. Day (eds.). The Indian Papers of Texas and the Southwest, 1825-1916. 4 vols. Austin, 1966.

Wood, William D. Reminiscences of Reconstruction in Texas and Reminiscences of Texas and Texans Fifty Years Ago. San Marcos, Texas, 1902.

Wooster, Ralph A. The People in Power: Courthouse and statehouse in the Lower South, 1850-1860. Knoxville, 1969 .

Works Progress Administration. Houston: A History and a Guide. Houston, 1942.

Wortham, Louis J. A History of Texas from Wilderness to Commonwealth. 5 vols. Fort Worth, $1 \overline{924}$.

Young, S. O. True Stories of old Houston and Houstonians. Galveston, 1913.

\section{Articles and Essays}

Axlerod, Bernard. "Galveston: Denver's Deep-Water Port," Southwestern Historical Quarterly, Lxx (1966-67), 217-28.

Baenziger, Ann Patton. "The Texas State Police During Reconstruction: A Reexamination," Southwestern Historical Quarterly, LXXII $(1968-69), 470-91$.

Barr, Alwyn (ed.). "Records of the Confederate Military Commission in San Antonio, July 2-October 10, 1862," Southwestern Historical Quarterly, LXX $(1966-67), 93-109, \overline{289-313,623}-\overline{44}$, LXXI (1967-68), 247-78. 
Barr, Alwyn. "Texas Coastal Defense, 1861-1865," Southwestern Historical Quarterly, LXV (1961-62), 1-31.

Barton, Henry w. "The United States Cavalry and the Texas Rangers," Southwestern Historical Quarterly, IXIII (1959-60), 495-510.

Biesele, R. L. "The Relations Between the German Settlers and the Indians in Texas, 1844-1860," Southwestern Historical Quarterly, $x x x I(1927-28), 116-29$.

- "The Texas State Convention of Germans in 1854," Southwestern Historical Quarterly, XXXIII (1929-30), 247-61.

Blackburn, J. K. P. "Reminj.scences of the Terry Rangers," Southwestern Historical Quarterly, XXII (1918-19), 143-79.

Bonham, Milledge L., Jr. "The French Consuls in the Confederate States," Studies in Southern History and Politics. New York, 1914.

Braly, Earl Burk. "Fort Belknap of the Texas Frontier," West Texas Historical Association, Year Book, XXX (1954), 83-114.

Brown, William Garrott. "The Ku Klux Movement," Atlantic Monthly, IXXXVII (1901), 634-44.

Byrne, Frank L. "'A Terrible Machine': General Neal Dow's Military Government on the Gulf Coast," Civil War History, XII (1966), 5-22.

"The Civil Record of Major General Winfield s. Hancock, During His Administration in Louisiana and Texas, 1871," Southern Review, IX (1871), 906-23.

Cohen, Barry M. "The Texas-Mexico Border, 1858-1867, . ," Texana, VI (1968), 153-65.

Cox, John and La Wanda. "General Howard and the 'Misrepresented Bureau," " Journal of Southern History, XIX (1953), 427-56.

Cox, La Wanda. "The Promise of Land for the Freedmen," Mississippi Valley Historical Review, XLV (1958), 413-40.

Cox, Merlin G. "Military Reconstruction in Florida," Florida Historical Quarterly, XLVI (1967-68), 219-33.

Crimmins, Martin L. "The Border Command at Fort Bliss," West Texas Historical and Scientific Society, Publications, No. I (December 1926), 16-20.

- "The First Line of Army Posts Established in West Texas in 1849," West Texas Historical Association, Year Book, XIX (1943), $121-27$. 
Crimmins, Martin L. "Fort McKavett, Texas," Southwestern Historical Quarterly, XXXVIII (1934-35), 28-37.

Crook, Carland Elaine. "Benjamin Theron and French Designs in Texas During the Civil War," Southwestern Historical Quarterly, LXVIII $(1964-65), 432-54$.

Cumberland, Charles c. "The Confederate Loss and Recapture of Galveston, 1862-1863," Southwestern Historical Quarterly, LI $(1947-48), 109-30$.

Delany, Robert W. "Matamoros, Port for Texas During the Civil War," Southwestern Historical Quarterly, LVIII (1954-55), 473-87.

Dill, Robert G. "The Soldiers' Homeward Voyage, a Thrilling Experience at the Close of the Late Civil War," Magazine of American History, XI (1884), 445-53.

Du Bois, W. E. Burghardt. "The Freedmen's Bureau," Atlantic Monthly, LXXXVII (1901), 354-65.

Dugan, Frank H. "The 1850 Affair of the Brownsville Separatists," Southwestern Historical Quarterly, LVI (1957-58), 270-87.

Duniway, C. A. "Reasons for the Withdrawal of the French from Mexico," Annual Report of the American Historical Association, I (1902), $\overline{313-28 .}$

Dykes, J. C. "Dime Novel Texas; or, the Sub-literature of the Lone Star state," Southwestern Historical Quarterly, XLIX (1945-46), $327-40$.

Eddins, Roy. "Falls County," Southwestern Historical quarterly, LIV $(1950-51), 219-27$.

Elliott, Claude. "The Freedmen's Bureau in Texas," Southwestern Historical Quarterly, LVI (1952-53), 1-24.

- "Union Sentiment in Texas, 1861-1865," Southwestern Historical Quarterly, L (1946-47), 449-77.

Ellis, L. Tuffly (ed.). "Lt. A. W. Greely's Report on the Installation of Military Telegraph Lines in Texas, 1875-1876," Southwestern Historical Quarterly, LXIX (1965-66), 66-87.

Ericson, J. E. "Origin of the Texas Bill of Rights," Southwestern Historical Quarterly, LXII (1958-59), 457-66.

Estill, Harry F. "The Old Town of Huntsville," The Quarterly of the Texas State Historical Association, III (1899-1900), 265-78. 
Ewing, Floyd F., Jr. "Origins of Unionist Sentiment on the West Texas Frontier," West Texas Historical Association, Year Book, XXXII (1956), 3-29.

Field, William T., Jr. "The Texas State Police, 1870-1873," Texas Military History, V (1965), 131-41.

Fitzhugh, Lester N. "Saluria, Fort Esperanza, and Military Operations on the Texas Coast, 1861-1864," Southwestern Historical Quarterly, LVI $(1957-58), 66-100$.

Fletcher, Henry T. "Old Fort Lancaster," West Texas Historical and Scientific Society, Publications, No. 44 (December 1932), 33-44.

Fletcher, John. "Fort Phantom Hill," Texas Military History, III (1963), 161.

Friend, Llerena B. "The Texan of 1860," Southwestern Historical Quarterly, LXII (1958-59), 1-17.

Gordon, Leonard. "Lincoln and Juarez--A Brief Reassessment," HispanicAmerican Historical Review, XLVIII (1968), 75-80.

Grant, Ben O. "Explorers and Early Settlers of Shackleford County," West Texas Historical Association, Year Book, XI (1935), 17-37.

Green, Fletcher M. "Democracy in the old South," Journal of Southern History, XII (1946), 3-23.

Hall, Martin H. "The Campbell-Sherman Diplomatic Mission to Me ico," Historical and Philosophical Society of ohio, Bulletin, XIII (1955), 254-70.

Harrison, Lowell H. "Supplying Texas Military Posts in 1876," Texas Military History, IV (1964), 23-24.

Hill, Lawrence F. "The Confederate Exodus to Latin America," Southwestern Historical Quarterly, XXXIX (1935-36), 100-34, 161-99, $309-26$.

Holden, W. C. "Frontier Defense, 1865-1889," Panhandle-Plains Historical Review, II (1929), 43-64.

- "Frontier Defense in Texas During the Civil War," West Texas Historical Association, Year Book, IV (1928), 16-31.

- "Law and Lawlessness on the Texas Frontier, 1875-1890," Southwestern Historical Quarterly, LXIV (1940-41), 188-203.

Howsley, Marilynne. "Forting up on the Texas Frontier During the Civil War," West Texas Historical Association, Year Book, XVII (1941), 71-76. 
Jones, Allen W. "Military Events in Texas During the Civil War, 18611865," Southwestern Historical Quarterly, LXIV (1960-61), $64-70$.

Kimbrough, W. C. "The Frontier Background of Clay County," West Texas Historical Association, Year Book, XVIII (1942), 116-31.

Lathrop, Barnes F. "Migration into East Texas, 1835-1860," South-

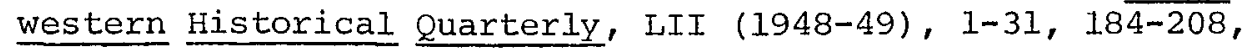
325-48.

Lightfoot, B. B. "From Frontier to Farmland: Highlights of the History of Comanche County," West Texas Historical Association, Year Book, XXXII (1956), 30-43.

- "The Negro Exodus from Comanche County, Texas," Southwestern Historical Quarterly, LVI (1952-53), 407-16.

McDonough, James L. "John Schofield As Military Director of Reconstruction in Virginia," Civil War History, XV (1969), 237-56.

McKay, S. S. "Social Conditions in Texas in the Eighteen Seventies," West Texas Historical Association, Year Book, XIV (1938), 32-51.

Macy, William Madison. "The Civil War Diary of William Madison Macy," Indiana Magazine of History, Xxx (1934), 181-97.

Maher, Edward R. "Sam Houston and Secession," Southwestern Historical Quarterly, LV (1951-52), 448-58.

Maresh, Henry R. "The Czechs in Texas," Southwestern Historical Quarterly, L (1946-47), 236-40.

Mayhall, Mildred P. "Camp Cooper--First Federal Fort in Texas to Fall, 1861, and Events Preceding Its Fall," Texana, V (1967), $317-42$.

Millex, E. T. "Repudiation of the State Debt in Texas Since 1861," Southwestern Historical guarterly, XVI (1912-13), 169-83.

- "The State Finances of Texas During the Civil War," The Quarterly of the Texas State Historical Association, XIV (1910-11), $1-\overline{19}$.

- "The State Finances of Texas During Reconstruction," The Quarterly of the Texas State Historical Association, XIV $\frac{\text { Ruarter }}{(1910-11)}, \overline{87} \overline{-109}$.

Miller, Robert Ryal. "Lew Wallace and the French Intervention in Mexico," Indiana Magazine of History, LIV (1963), 31-50. 
Miller, Robert Ryal. "Matias Romero: Mexican Minister to the United States During the Juarez-Maximilian Era," Hispanic-American Historical Review, XLV (1965), 228-45.

Mitchell, Leon, Jr. "Camp Groce: Confederate Military Prison," Southwestern Historical Quarterly, LXVII (1963-64), 15-21.

Neighbours, Kenneth. "Elm Creek Raid in Young County, 1864," West Texas State Historical Association, Year Book, XL (1964), 83-89.

Oates, Stephen B. "John S. 'Rip' Ford: Prudent Cavalryman, C.S.A.," Southwestern Historical Quarterly, LXIV (1960-61), 289-314.

- "Recruiting Confederate Cavalry in Texas," Southwestern Historical Quarterly, LXIV (1960-61), 463-77.

- "Texas Under the Secessionists," Southwestern Historical Quarterly, LXVII (1963-64), 167-212.

Page, Thomas Nelson. "The Southern People During Reconstruction," Atlantic Monthly, LXXXVII (1901), 289-304.

Pate, J'Nell. "United States-Mexican Border Conflicts, 1870-1880," West Texás Historical Association, Year Book, XXXVIII (1962), 175-94.

Peek, Ralph L. "Military Reconstruction and the Growth of Anti-Negro Sentiment in Florida, 1867," Florida Historical Quarterly, XLVII (1968-69), 380-400.

Pool, William C. "The Battle of Dove Creek," Southwestern Historical Quarterly, LIII (1949-50), 367-85.

Ramsdell, Charles w. "The Frontier and Secession," studies in Southern History and Politics. New York, 1914. 63-75. - "The Last Hope of the Confederacy--John Tyler to the Governor and Authorities of Texas," The Quarterly of the Texas

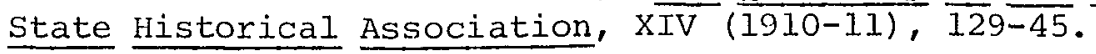

Richardson, Joe M. "Florida Black Codes," Florida Historical Quarterly, XLVII (1968-69), 365-79.

Rister, C. C. (ed.). "Early Accounts of Indian Depredations," West Texas Historical Association, Year Book, II (1926), 18-44.

Russ, William A., Jr. "Radical Disfranchisement in Texas, 1867-1870," Southwestern Historical Quarterly, XXXVIII (1934-35), 40-52.

Shook, Robert W. "The Battle of the Nueces, August 10, 1862," Southwestern Historical Quarterly, LXVI (1962-63), 31-42. 
Shook, Robert $W$. "The Federal Military in Texas, 1865-1870," Texas Military History, VI (1967), 3-53.

. "Military Activities in Victoria, 1865-1866," Texana, III (1965), 347-52.

Singletary, Otis A. "The Texas Militia During Reconstruction," Southwestern Historical Quarteriy, LX (1956-57), 23-35.

Skinner, A. E. "Forgotten Guardians: The Activities of Company 'C', Frontier Forces, 1870-1871," Texana, VI (1968), 107-21.

Smyr1, Frank H. "Texans in the Union Army, 1861-1865," Southwestern Historical Quarterly, LXV (1961-62), 234-50.

Snead, Edgar P. "A Historiography of Reconstruction in Texas: Some Myths and Problems," Southwestern Historical Quarterly, LXXII $(1968-69), 435-48$.

Somers, Dale A. "James P. Newcomb: The Making of a Radical," Southwestern Historical Quarterly, LXXII (1968-69), 449-69.

Spindler, Frank MacD. "Concerning Hempstead and Waller County," Southwestern Historical Quarterly, LIX (1955-56), 455-72.

. "The History of Hempstead and the Formation of Waller County," Southwestern Historical quarterly, IXIII (1959-60), $404-27$.

Terrell, Alexander $W$. "The City of Austin from 1839-1865," The Quarterly of the Texas State Historical Association, XIV (1910-11), $113-28$.

Thompson, Taylor. "Reconstruction Days in San Antonio," Frontier Times (November 1923), 28-29.

Vandiver, Frank E. "Texas and the Confederate Army's Meat Problem," Southwestern Historical Quarterly, XLVII (1943-44), 225-33.

Wheeler, T. B. "Reminiscences of Reconstruction in Texas," The Quarterly of the Texas State Historical Association, $\overline{\mathrm{XI}}$ $\frac{\text { suarter }}{(1907-1908),}, 56-65$.

Whisenhunt, Donald w. "Fort Richardson: Outpost on the Texas Frontier," Southwest Studies, V (No. 4, 1968).

White, William W. "The Texas Slave Insurrection of 1860," Southwestern Historical Quarterly, LII (1948-49), 259-85.

Williams, T. Harry. "Lincoln and the Radicals: An Essay in Civil War History and Historiography," Grady McWhiney (ed.), Grant, Lee, Lincoln and the Radicals: Essays on Civil War Leadership. $\overline{\text { New York, } 1966 .} \overline{92-1} \overline{15 .}$ 
Wilson, Aubrey A. "A Soldiex of the Texas Frontier: Brevet Major Robert Patterson Wilson, United States Army," West Texas Historical Association, Year Book, XXXIV (1958), 82-96.

Winkler, E. W. (ed.). "The Bryan-Hayes Correspondence," Southwestern Historical quarterly, XXV (1921-22), 274-99, XXVI (1922-23), 58-70.

Wood, W. D. "The Ku Klux Klan," The Quarterly of the Texas State Historical Association, IX (1905-1906), 262-68.

Wooster, Ralph A. "An Analysis of the Membership of the Texas Secession Convention," Southwestern Historical quarterly, LXII (1958-59), 322-35.

- "An Analysis of the Texas know Nothings," Southwestern Historical Quarterly, LXX $(1966-67), 414-23$.

Young, Jo. "The Battle of Sabine Pass," Southwestern Historical Quarterly, LII (1948-49), 398-409.

3. Unpublished Theses, Dissertations, and Papers

Adkins, John Robert. "The Public Career of A. J. Hamilton." Unpublished M.A. thesis, University of Texas, 1947.

Anderson, Thomas Franklin. "A History of Indianola." Unpublished M.A. thesis, University of Houston, 1951.

Arnold, Marcus Llewellyn. "The Later Phases of the Secessionist Movement in Texas." Unpublished M.A. thesis, University of Texas, 1920 .

Atkinson, Bertha. "The History of Bell County." Unpublished M.A. thesis, University of Texas, 1929.

Barrett, nxrie. "Federal Outposts in Texas, 18tornow M.A. thesis, University of Texas, 1927.

Biesele, Rudolph Leopold. "The History of the German Settlements in Texas, 1831-1861." Unpublished Ph.D. dissertation, University of Texas, 1928.

Boethel, Paul Carl. "The History of Lavaca County, 1685-1930." Unpublished M.A. thesis, University of Texas, 1932.

Boon, Effie Mattox. "The History of Angelina County." Unpublished M.A. thesis, University of Texas, 1937.

Boozer, Jesse Beryl. "The History of Indianola, Texas." Unpublished M.A. thesis, University of Texas, 1942. 
Bowden, Malvin George. "History of Burnet County." Unpublished I.A. thesis, University of Texas, 1940.

Bowles, Flora G. "The History of Trinity County." Unpublished M.A. thesis, University of Texas, 1928.

Budd, Harrel1. "The Negro in Politics in Texas, 1867-1898." Unpublished M.A. thesis, University of Texas, 1925.

Cassles, Anne Ethel. "A History of Hunt County." Unpublished M.A. thesis, University of Texas, 1935.

Chandler, Barbara Susan Overton. "A History of Bowie County." Unpublished M.A. thesis, University of Texas, 1937.

Cole, Fred C. "The Texas Career of Thomas Affleck." Unpublished Ph.D. dissertation, Louisiana State University, 1942.

Cowling, Annie. "The Civil War Trade of the Lower Rio Grande Valley." Unpublished M.A. thesis, University of Texas, 1926.

Cox, Alonzo Bettis. "The Economic History of Texas During the Period of Reconstruction." Unpublished M.A. thesis, University of Texas, 1914.

Cravens, John Nathan. "The Life and Activities of James Harper Starr, 1809-1890." Unpublished Ph.D. dissertation, University of Texas, 1948.

Curtis, Sara Kay. "A History of Gillespie County, Texas, 1846-1900." Unpublished M.A. thesis, University of Texas, 1943.

Dobie, Dudley Richard. "History of Hays County, Texas." Unpublished M.A. thesis, University of Texas, 1932.

Dugas, Vera Lee. "A Social and Economic History of Texas in the Civil War and Reconstruction Periods." Unpublished Ph.D. dissertation, University of Texas, 1963.

Ellsworth, Lois. "San Antonio During the Civil War." Unpublished M.A. thesis, University of Texas, 1938.

Felgar, Robert Pattison. "Texas in the War for Southern Independence." Unpublished Ph.D. dissertation, University of Texas, 1935.

Fry, Tillie B. M. "A History of Llano County, Texas." Unpublished M.A. thesis, University of Texas, 1943.

Garner, Ruby Lee. "Galveston During the Civil War." Unpublished M.A. thesis, University of Texas, 1927.

Good, Benjamin Harvey. "John Henninger Reagan." Unpublished Ph.D. dissertation, University of Texas, 1932. 
Goodlett, Margaret Amelia Nance. "The Enforcement of the Confederate Conscript Acts in the Trans-Mississippi Department." Unpublished M.A. thesis, University of Texas, 1914.

Gunn, Jack Winston. "Life of Ben McClllloch." Unpublished M.A. thesis, University of Texas, 1947.

Haley, John Evetts. "A Survey of Texas Cattle Drives to the North, 1866-1895." Unpublished M.A. thesis, University of Texas, 1926.

Hall, Ada Marie. "The Texas Germans in State and National Politics, 1850-1865." Unpublished M.A. thesis, University of Texas, 1938.

Hammons, Nancy Lee. "A History of El Paso County." Unpublished M.A. thesis, University of Texas, El Paso, 1942.

Hayman, Bettie. "A Short History of the Negro of Walker County, 18601942." Unpublished M.A. thesis, Sam Houston State College, 1942.

Haynes, Rose Mary F. "Some Features of Negro Participation in Texas History Through 1879." Unpublished M.A. thesis, Texas College of Arts and Industries, 1948.

Heintzen, Frank W. "Fredericksburg, Tëxas, in Civil War and Reconstruction." Unpublished M.A. thesis, St. Mary's University, 1944.

Hill, James Lyle. "The Life of Judge William Pitt Ballinger." Unpublished M.A. thesis, University of Texas, 1937.

Holbert, Ruby Crawford. "The Public Career of James Webb Throckmorton, 1851-1867." Unpublished M.A. thesis, University of Texas, 1932.

Holladay, Florence Elizabeth. "The Extraordinary Powers and Functions of the General Commanding the Trans-Mississippi Department of the Southern Confederacy." Unpublished M.A. thesis, University of Texas, 1914.

Johnson, Thomas Heskill. "Relations with the Indians on the Texan Frontier, 1858-1859." Unpublished M.A. thesis, University of Texas, 1935.

Jordan, Edith Marian. "The History of Parker County." Unpublished M.A. thesis, University of Texas, 1935.

King, Alma Dexta. "The Political Career of Williamson Simpson Oldham." Unpublished M.A. thesis, University of Texas, 1929.

Koch, Lena Clara. "The Federal Indian Policy in Texas, 1845-1860." Unpublished M.A. thesis, University of Texas, 1922. 
Lambert, Joseph I. "The Defense of the Indian Frontier of Texas by the United States Army." Unpublished M.A. thesis, St. Mary's University, 1948.

Lambie, Agnes Louise. "Confederate Control of Cotton in the TransMississippi Department." Unpublished M.A. thesis, University of Texas, 1915.

Love, John Warren. "The Regulator-Moderator Movement in Shelby County." Unpublished M.A. thesis, University of Texas, 1936.

Lowman, Berta. "Cotton Industry in Texas During the Reconstruction Period." Unpublished M.A. thesis, University of Texas, 1927.

MoArthur, Daniel Evander. "The Cattle Industry in Texas, 1590-1918." Unpublished M.A. thesis, University of Texas, 1918.

McKay, Seth Shepard. "Texas Under the Regime of E. J. Davis." Unpublished M.A. thesis, University of Texas, 1919.

Madole, Jewel Pickford. "A History of Salado, Texas." Unpublished M.A. thesis, University of Texas, 1952 .

Mahoney, Leo Edwin. "The Camel Corps: An Attempted Solution of the Problem of Western Transportation." Unpublished M.A. thesis, University of Texas, 1928.

Marr, John Columbus. "The History of Matagorda County, Texas." Unpublished M.A. thesis, University of Texas, 1928.

Marshall, Elmex Grady. "The History of Brazos County, Texas." Unpublished M.A. thesis, University of Texas, 1937.

Martin, James Lee. "History of Goliad, 1836-1880." Unpublished M.A. thesis, University of Texas, 1937.

Megee, Jonnie Mildred. "Confederate Impressment Acts in the TransMississippi Department." Unpublished M.A. thesis, University of Texas, 1915.

Meredith, Mary Owen. "The Life and Work of Thomas Jefferson Devine." Unpublished M.A. thesis, University of Texas, 1930.

Merseburger, Marion. "A Political History of Houston, Texas, During the Reconstruction Period as Recorded by the Press, 1863-1873." Unpublished M.A. thesis, Rice University, 1950.

Miller, Benjamin Hillon. "Elisha Marshall Pease: A Biography." Unpublished M.A. thesis, University of Texas, 1927.

Moellexing, Arwerd Max. "A History of Guadalupe County, Texas." Unpublished M.A. thesis, Ur.iversity of Texas, 1938. 
Moore, Sue Estella. "Life of John Benjamin Long." Unpublished M.A. thesis, University of Texas, 1924.

Muckleroy, Anna. "The Indian Policy of the Republic of Texas." Unpublished M.A. thesis, University of Texas, 1919.

Myers, Ila Mae. "The Relations of Governor Pendleton Murrah of Texas with the Confederate Military Authorities." Unpublished M.A. thesis, University of Texas, 1929.

Mysliwiec, Chester P. "A History of Karnes County, Texas." Unpublished M.A. thesis, University of Texas, 1952.

O'Bannion, Maurine Mattie. "The History of Caldwell County." Unpublished M.A. thesis, University of Texas, 1931.

Pierson, Oris Emerald. "Norwegian Settlements in Bosque County, Texas." Unpublished M.A. thesis, University of Texas, 1947.

Pool, William Clayton, Jr. "The History of Bosque County." Unpublished M.A. thesis, University of Texas, 1946.

Real, Matilda Marie. "A History of Kerr County, Texas." Unpublished M.A. thesis, University of Texas, 1942.

Reese, James Verdo. "A History of Hill County, Texas, to 1873." Unpublished M.A. thesis, University of Texas, 1961.

Ruckman, Caroline Silsby. "The Frontiex of Texas During the Civil War." Unpublished M.A. thesis, University of Texas, 1926.

Ryan, Frances Dora. "The Election Laws of Texas, 1827-1895." UnpubIished M.A. thesis, University of Texas, 1922.

St. Clair, Gladys Annelle. "A History of Hopkins County, Texas." Unpublished M.A. thesis, University of Texas, 1940.

St. Clair, Lawrence Ward. "History of Robertson County." Unpublished M.A. thesis, Uiziversity of Texas, 1931.

Scaief, James Seborn. "Texas in National Periodical Literature from 1865-1885." Unpublished M.A. thesis, University of Texas, 1949.

Sergeant, George W. "Early History of Tarrant County." Unpublished M. A. thesis, University of Texas, 1953.

Sinclair, Lonnie. "The Freedmen's Bureau in Texas: The Assistant Commissioners and the Negro." Unpublished Paper Submitted to the Institute of Southern Hisstory, The Johns Hopkins University, July 22, 1969. 
Skinner, Frances. "The Trial and Release of Satanta and Big Tree: State-Federal Relations During the Reconstruction Era." Unpublished M.A. thesis, University of Texas, 1937.

Smyr1, Frank Herbert. "Unionism, Abolitionism, Vigilantism in Texas, 1856-1865." Unpublished M.A. thesis, University of Texas, 1961.

Tausch, Egon Richard. "Southern Sentiment Among the Texas Germans During the Civil War and Reconstruction." Unpublished M.A. thesis, University of Texas, 1965.

Terrill, Annie Charlotte. "A Calendar of the Memorials and Petitions to the Legislature of Texas, 1861-1877." Unpublished M.A. thesis, University of Texas, 1936.

Turner, Oreta. "Border Troubles Along the Rio Grande from 1848-1878." Unpublished M.A. thesis, East Texas State University, 1940.

Ulrich, William John. "The Northern Military Mind in Regard to Reconstruction, 1865-1872: The Attitudes of Ten Leading Union Generals." Unpublished Ph.D. dissertation, Ohio State Unjeversity, 1959 .

Vowell, Jack C., Jr. "Politics at El Paso, 1850-1920." Unpublished M.A. thesis, University of Texas, El Paso, 1952.

Wallis, Mary Ella. "The Life of Alexander Watkins Terrel1, 1827-1912." Unpublished M.A. thesis, University of Texas, 1937.

White, Frank Edd. "A History of the Territory that Now Constitutes Waller County, Texas, from 1821 to 1884." Unpublished M.A. thesis, University of Texas, 1936.

Winfrey, Dorman Hayward. "A History of Rusk County, 'Texas." Unpublished M.A. thesis, University of Texas, 1951.

Yelderman, Pauline. "The Jaybird Democratic Association of Fort Bend County." Unpublished M.A. thesis, University of Texas, 1938. 
VITA

William I. Richter was born in Fort Madison, Iowa, and raised in Phoenix, Arizona. He was educated in the Phoenix public school system, and graduated from West High School in 1960. Between that date and 1965, he attended Arizona state University where he received his B.A. and M.A. degrees. He begar. his work on the Ph.D. at Iouisiana State University in January 1966 and plans to graduate in August 1970. 
Candidate: William L. Richter

Major Field: History

Title of Thesis: The Army in Texas During Reconstruction, 1865-1870

Approved:

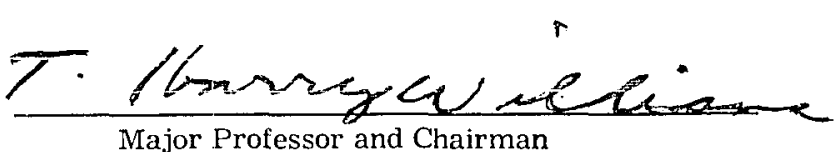

Major Professor and Chairman

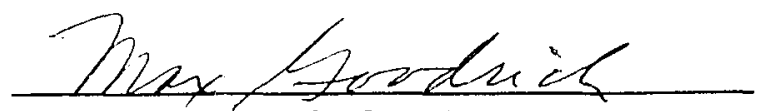

Dean of the Graduate School

EXAMINING COMMITTEE:

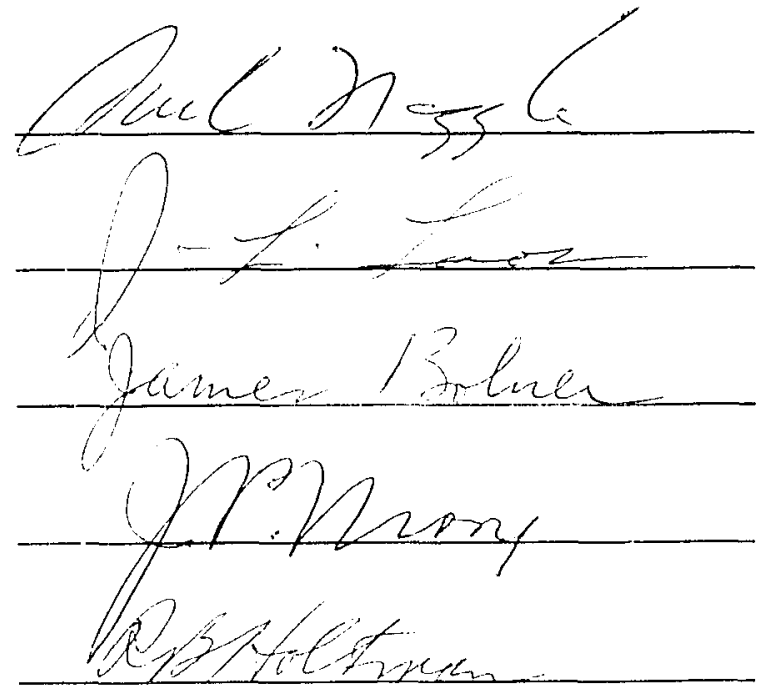

Date of Examination:

July 15, 1970

Reproduced with permission of the copyright owner. Further reproduction prohibited without permission. 